
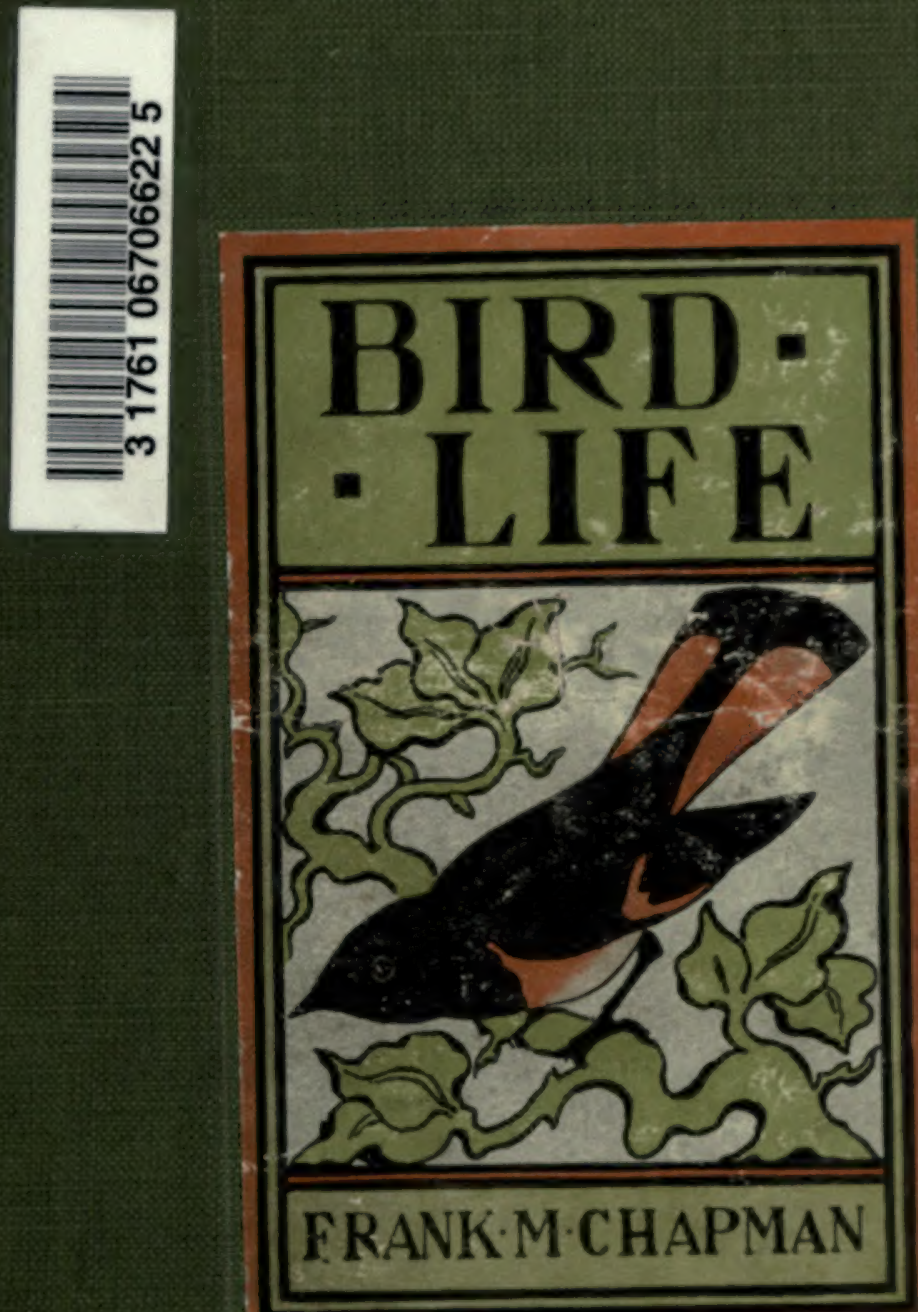


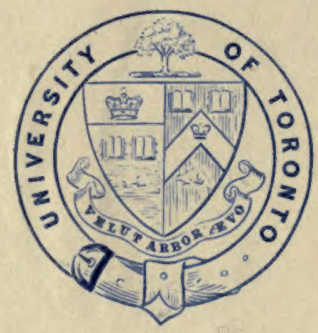

Dresented to

The Library of the

\section{University of Coronto}

by

IDrg. 3. F. 1bart 

Digitized by the Internet Archive in 2007 with funding from Microsoft Corporation 


\section{By FRANK M. CHAPMAN,}

Curator of Birds in the American Museum of Natural History.

HANDBOOK OF BIRDS OF EASTERN NORTH AMERICA.

With Keys to the Species, Descriptions of their Plumages, Nests, etc., and their Distribution and Migrations. With over 200 Illustrations. 12mo. LIBRARY EDITION, \$3.00.

POCKET EDIrION, flexible covers, \$3.50.

BIRD-LIFE. $\Lambda$ Guide to the Study of Our Common Birds.

Popular Edition in colors, $\$ 2.00$ net.

\section{BIRD STUDIES WITH A CAMERA. With Introductory} Chapters on the Outfit and Met hods of the Bird Photographer.

Illustrated with over 100 Photographs from Nature by the Author. 12mo. Cloth, \$1.75.

\section{THE WARBLERS OF NORTH AMERICA.}

With Contributions from other Ornithologists and 24 full-page Colored Plates illustrating every Species, from Drawings by L. A. Fuertes and B. Horsfall, and Half-tones of Nests and Eggs. 8vo. Cloth, $\$ 3.00$ net.

\section{CAMPS AND CRUISES OF AN ORNITHOLOGIST.}

Illustrated by 250 Photographs from Nature by the Author. 8vo. Cloth, $\$ 3.00$ net.

D. APPLETON AND COMPANY, NEW YORK. 


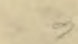




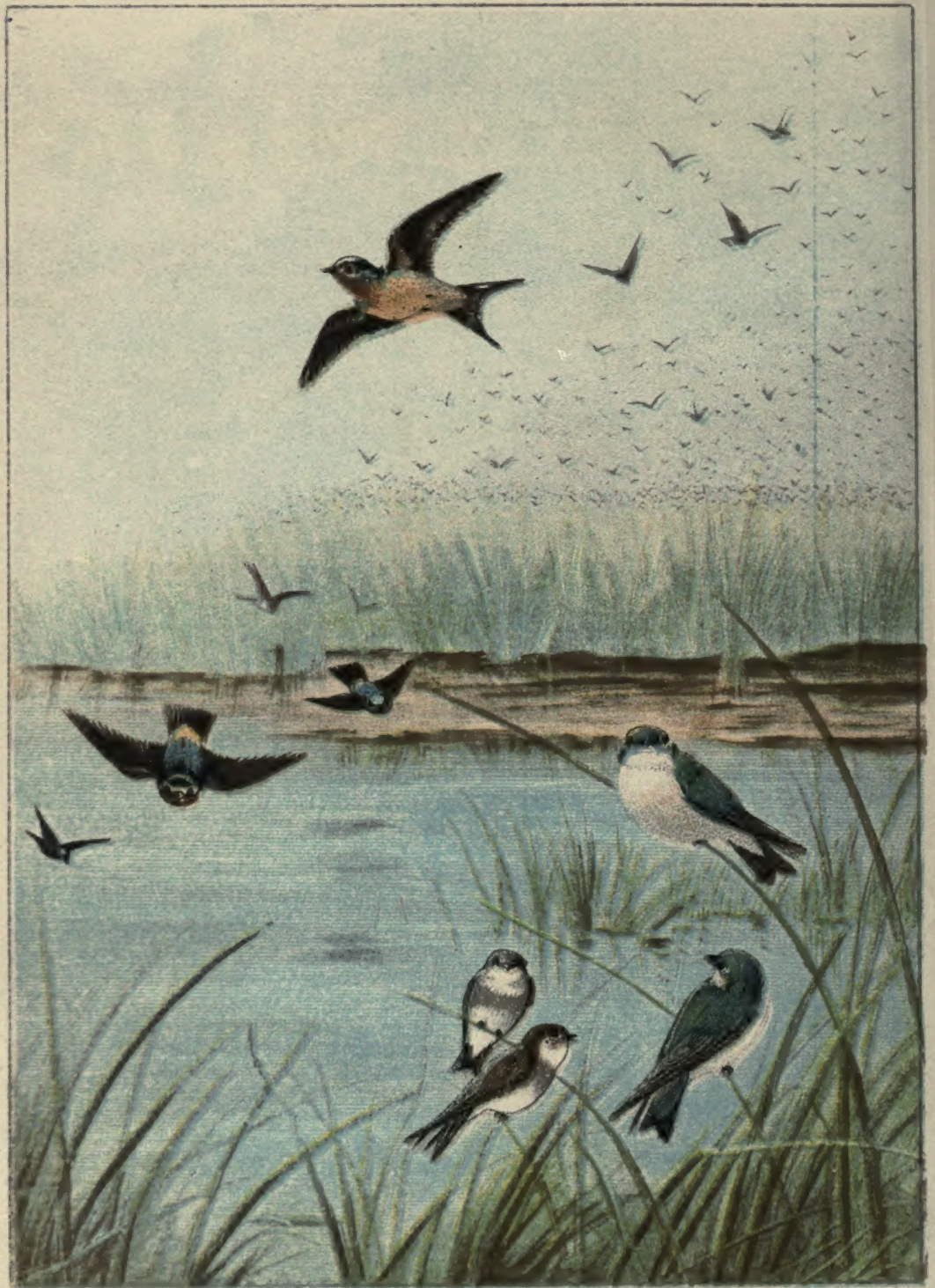

Pinte I.

Page 156.

BARN SWALLOW.

CLIFF SWALLOW. TREE SWALLOW. BANK SWALLOW. 
$z_{C}^{z} A_{v}$

\section{POPULAR EDITION IN COLORS}

\section{BIRD-LIFE}

A GUIDE TO THE STUDY OF OUR COMMON BIRDS

\section{BY \\ FRANK M. CHAPMAN}

CURATUR OF ORNITHOLOGY, AMERICAN MUSEUM OF NATURAL HISTOKY; FELLOW OF THE AMERICAN ORYTTHOLOGISTS VINION AUTHOR OF "HANDBOOK OF BIRDS OF \&ASTERN NOKTH AMERICA."

"BIRD STUDIES WITH A CAMERA," "CAMPS AND CRUISES OF AN ORNITHULOGIST," ETC.

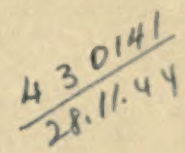

WITH SEVENTY-FIVE FULL-PAGE COLORED PLATES AFTER DRAWINGS BY ERNEST THOMPSON SETON

TORONTO MCCLELLAND \& GOODCHILD LIMITED 
study, but are always about us, and even a slight familiarity with them will be of value long after school days are over.

Popular interest must precede the desire for purely technical knowledge. The following pages are not addressed to past masters in ornithology, but to those who desire a general knowledge of bird.life and some acquaintance with our commoner birds. The opening chapters of this book briefly define the bird, its place in Nature and its relation to man, and outline the leading facts in its life-history. The concluding chapters present the portraits, names, and addresses of upward of one hundred familiar birds of eastern North America, with such information concerning their comings and goings as will lead, I trust, to their being found at home.

After this introduction the student may be left on the threshold, with the assurance that his entrance to the innermost circles of bird-life depends entirely on his own patience and enthusiasm.

Frank M. Chapman.

american Museum of Natural History,

NEW YoRk CITY, January, 189\%. 


\section{PREFACE TO POPULAR COLORED EDITION.}

Wrrнovr question the simplest and most certain way in which to become acquainted with our birds is to examine the bird itself. Unfortunately for the stadent, wild birds seem averse to this proceeding, while comparatively few people have access to an ornithological collection. For purposes of identification, therefore, the best substitute for the bird is an accurate plate which shall adequately portray both the form and color of its subject.

The fact that Mr. Thompson Seton's drawings in the uncolored edition of "Bird-Life" have been conceded to excel in truth and beauty any series of black-and-white bird portraits ever published in this country gives reason, therefore, for the belief that bird lovers will doubly welcome a work in which our commoner birds are represented not only in natural attitudes, but in natural colors as well. Photographic bromide copies of the original "BirJ-Life" drawings have been colored by an expert under the author's supervision, and are here reproduced by lithography.

In selecting the one hundred species to be figured in this book it has been deemed advisable to omit those, 
vi PREFACE TO POPULAR COLORED EDITION.

like the Crow and Robin, with which every one is familiar, as well as those, like the Cardinal and Scarlet Tanager, whose identity can be ascertained beyond question by descriptions, and to introduce in their places birds with which beginners are less apt to be familiar, thereby increasing the educational value of the illustrations.

F. M. C.

Americay Museuji or Naturat History,

March, 1901. 


\section{CONTENTS.}

crup.

TAOE

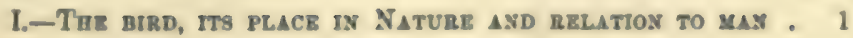

Place in Nature-Relation to man.

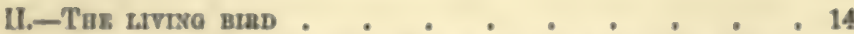

Factors of evolution-The wing, its form and usesThe tail, its form and uses-The foot, its torm and uses -The bill, its form and uses.

III.-Cotors of Bmps . . . , . , . , . 25

Color and age - Color and season-The molt-Color and food-Color and climate-Color and haunt and habitColor and sex.

IV.-Thв groration ov girds . . . . . . . 48

Estent of migration-Times of migration-Manner of migration-Origin of migration.

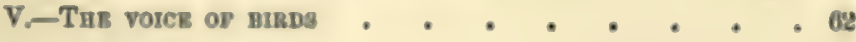
Song-Call-notes.

VI. The kestivo seasos . . . . . . . . 64

Time of nesting-Mating-The nest-The eggs-The young.

VII.-How to IDEXTIY BIRDS

A bird's biography.

Frald ket to our common Land Bimd . . . . 75 vii 
The Water Birds

Diving Birds-Long-winged Swimmers-Tube-nosed Swimmers-Lamellirostrul Swimmers-Hlerons, Storks, Ibises, etc. -Cranes, Rails, etc.-Shore Birds.

The Land Birds . . . . . . . . . 100

Gallinaceous Birds-Pigeons and Doves-Birds of PreyCuckons, Kingfishers, etc. - Woodpeckers - Goatsuckers, Swifts, and Hummingbirds-Perching Birds.

APPENDIX. 


\section{LIST OF ILLUSTRATIONS.}

\section{FuLL-PAGE PLATES.}

FuTE

I.-Barn. Cliff. Bank, and Tree Swallows Frontispiece

II.-Pied-billed Grebe . . . . . . . • \&

III,-Loon • • • • • . • • • . 6

IV.-Ilerring Gull; Petrels. . . . . . . 10

V.-Wool Duck; Pintails: Mallarils: Green-winged

Teal; Blue-winged Teal; Canada Geese . . 14

VI.-Little Green Heron; Black-crowned Night Heron;

Great Blue Heron $\because$. . . . 18

VII.American Bittern: Snra ‘ . . . . . . 22

VIII_-Amerienn Cuot; Clapper Rail . . . . . . 26

IX.WWilson's Snipe . • • . • . • . 30

X.-Common Tern; Semipalmated Sandpiper; Semipalmated Plover . . . . . . . 34

XI.-Spntted Sandpiper; Killdeer . . . . . 38

XII.-Ruffed Grouse . . . . . . . . 42

XIII_-Mourning Dove . . . . . . . . 46

XIV.-Red-shouldered Hawk. . . . . . . . 50

XV.-Marsh Hawk . . . . . . . . 52

XVI.-Sparrow Hawk . . . . . . . . 54

XVII.-Sharp-shinned Hawk 。 . . . . . . 56

XVIII_American Oeprey. . . . . . . . 58

XIX_-Shnrt-eard OwI . . . . . . . 60

XX.-Sureech Owl . . .

XXI-Barreal OwI . . . . . . . . . . 64

XXII.-Yollnw-hillerl Cnckoo . . . . . . . 66

XXIIT.Belted Kingfiaher . . . . . . . 68

XXIV,-Dnwny Wmolnecker . . . . . . . 70

XXV.-Rerl-headed Woodpecker . . . . . . 84

XXVI_-Flicker . . . . . . . . . . 86

XXVII.-Nighthawk; Whip-ponr-will . . . . . 88 
rhats

racre

PAGL

XXVIII.Chimney Swift . . . . . . . . 90

XX1X.-lRuby-throated Hummingbird . . . . . 92

XXX.Kingbird . . . . . . . . 94

XXXI.-Crested Flycatcher . . . . . . . . 96

XXXIL_-Phobe , . . . . . . . . 98

XXXIIL_Wood Pewee . . . . . . . . 100

XXXIV.-Horned Lark . . . . . . . 102

XXXV.-Baltimore Oriole . . . . . . 104

XXXVI.-Orchard Oriole . . . . . . . . 106

XXXVII,-Purple Grackle . . . . . . . . 108

XXXVIH_-Bubuliuk . . . . . . . . 110

XXXIX_-Meadowlark . . . . . . 112

XL-Cowbird . . . . . . . . . 114

XI.l.-Sung Sparrow . . . . . . . 116

XLIL_-Swamp Sparrow . . . . . . . . 118

XLIIL,Field Sparrow . . . . . . . . 120

XLIV.-Vesper Sparrow . . . . . . . . 122

XLV.-Chipping Sparrow . . . . . . . 124

XLVI,-White-throated Sparrow . . . . . . 126

XLVIL,-Fox Sparrow , . . . . . . . 128

XLVIII.Junco . . . . . . . . . 130

XLIX.Tree Sparrow . . . . . . . . 132

I - -Redpoll : Snowflake . . . . . . . 134

LI.-American Crossbill; Pine Grosbeak . . . 136

LII.-American Goldfinch . . . . . . . 138

LIII_-Purple Finch . . . . . . . . 140

LIV.-Rose-breasted Grosbeak . . . . . . 142

IV.-Towhee, . . . . . . . 144

LVI.Díckcissel . . . . . . . . . 146

LVII_Cedar Warwing. . . . . . . . 148

LV1Il.-Northern Shrike . . . . . . . 150

LIX.-Rerl-eyed Vireo: Fellow-throated Vireo . . . 152

LX. Black and White Warbler. . . . . . 154

LXI.-M yrtle Warbler ; Bluck-throated Green Warbler . 156

LXII.-Rerlatart . . . . . . . . . 158

IAXIII,-Oren-bird . . . . . . . . 160

L.XIV.-Muryland Jellow-throat . . . . . . 102

L.XV.-Yallow-hreasted Chat . . . . . . 164

LXVI_Mnekinghird . . . . . . . . . 106

I.XVII,-Brown Thrasher . . . . . . . 168

LXVII.-Rouse Wren , . . , , . . . 170

LXIX.-Imng-billed Marsh Wren . . . . . . 172

LXX.-Brown Creeper; Chickadee . . . . . 174 
LXXI,-Red-breasted Nuthatch; White-breasted Nuthatch FAiE

LXXII.-Golden-crowned Kinglet; Ruby-crowned Kinglet . 178

LXXIII_Veery . . . . . . . , . . 180

LXXIV, -Wool Thrush . . . . . . . . 182

LXXV.-Hermit Thrush . . . . . . . . 184

\section{FIGURES IN THE TEXT.}

no.

1. Restoration of the Archæopteryx, a toothed, reptilelike bird of the Jurassic period . . . . . . . 3

2. End of spearlike tongue of l'ileated Woodpecker . . . 14

3. Tip of tuil of (a) Downy Wuodpecker, (b) Brown Creeper, to show the prointed shape in tuils of creeping birds of different families . . . . . . . . . 16

4. Young Iloutzin, showing use of hooked fingers in climbing . 17

5. Short, rouncled wing and large foot of Little Black Rail, a terrestrial bird . . . . . . . 18

6. Long, pointed wing and small foot of Tree Swallow, an airial bird

7. Frigate-bird

8. Great Auk, showing relatively small wing . . . . 21

9. Wing of Wondcock, showing three outer attenuate feathers . 24

10. Jacana, showing spurred wing and elongated toes . . . 24

11. Tail-feathers of Motmot (Momotus anbrufescens), showing newly grown feathers and results of self-inflicted mutilation . 26

12. Lobed foot of Coot (Fulica americana), a swimming bird of the Rail family . . . . . . . . 97

13. Lobed font of a Phalarope (Crymophilus fulicarius), a swim. ming bird of the Snipe family . . . . . .

14. Flamingo, showing relativo length of legs and neck in a wading bird .

15. Foot of Fish Hawk, showing large claws and spicules on under surface of toes . . . . . . . . .

16. Naked toes of Ruffed Grouse in summer; fringed toes of Ruffed Grouse in winter . . . . . . . . . 29

17. Decurved bill of Sickle-bill Hummingbird . . . . 31

18. Serrate bill of Merganser, a fish-eating bird . . . . 82

19. Probelike hill of $W$ ondeock, showing extent to which upper mandible can be mored. , . . . . 32

20. Recurred bill of Arocet . . . . . . , . 82

21. Bill of Spoonbill Sandpiper . . . . . . . 38 
res.

22. Curved bill of female, straight bill of male Huia-bird

23. Feathers frou luack of Sunw flake. showing seasuual changes in form and color due to wearing off of tips . . . . 38

24. Figgs of (a) Sprotted Sundpiper and (b) Catbird, to show difference in size of eggs of proccocial and altricial birds of same sizo. - 68

25. Toprography of a bind. 


\section{BIRD-LIFE.}

\section{CHAPTER I. \\ THE BIRD: ITS PLACE IN NATURE AND REIATION TO MAN.}

The Bird's Place in Nature.*-Abont thirteen thousand species of birds are known to science. The structure of many of these has been earefully studied, and all have been classified, at least provisionally. Taken as a whole, the class Ares, in which all birds are placed, is more clearly defined than any other group of the higher animals. That is, the most unlike birds are more closely allied than are the extremes anong mammals, fishes, or reptiles, and all living birds possess the distinctive oharacters of their class.

When compared with other animals, birds are found to occupy secon 1 place in the scale of life. They stand between inammals and reptiles, and are more closely related to the latter than to the former. In fact, certain extinct birds so clearly connect living birds with reptiles, that these two classes are sometimes placed in one group-the Sanropsida.

- On the structure of birds read Cones's Kev to North American Birds, Part 11 (Estes \& Isauriat): Heulley. The Structure and Lifo of Birds: Newton's Dictionary of Birds-articles, Anntomy of Birls and Fossil Birils: Martin and Moale s Ilundbnok of Vertebmte Dissection. Part 11. How to Dissect a Bird; Stulelult's Myology of tho Raven (Maomillan Co.). 
The characters that distinguish birds from mammals un the one hand, and from reptiles on the other, are more apparent than real. Thus flight, the most striking of a birl's gifts, is shared by bats among manmals. Egg-laying is the habit of most reptiles and of three mammals (the Australian duckbill and the echidnas). But incubation by one or both of the parents is peculiar to birds, shough the python is said to coil on its eggs.

Birds breathe more rapidly than either mammals or reptiles, and their pneumaticity, or power of inflating numerous air-sacs and even certain bones, is unique.

The temperature of birds ranges from $100^{\circ}$ to $112^{\circ}$, while in mammals it reaches $98^{\circ}$ to $100^{\circ}$, and in the comparatively cold-blooded reptiles it averages only $40^{\circ}$.

The skull in mammals articulates with the last rertebra (atlus) by two condyles or balls; in birds and reptiles by only one. In manmals and birds the heart has four chamhers; in reptiles it has but three.

Mammals and reptiles both have teeth, a character prssessed by no existing hird; lut fossil birds apparently prove that early in the development of the class all binds had teeth.

Thus we might continue the comparison, finding that birils have no universal peculiarities of structure which are not present in some degree in either mammals or reptiles, until we come to their external covering. The reptile is scaled, and so is the fish; the mammal is haired, and so are sume insects; but birds alone possess feathers. They are worn by every bird-a fit clothing for a body which is a marvelous combination of beauty, lightness, and strength.

There is good evidence for the belief that birds have desecended from reptilian ancestors. This evidence congivts of the renains of fossil hirds, some of which show markod reputilian characters and, as just said, are toothed. 


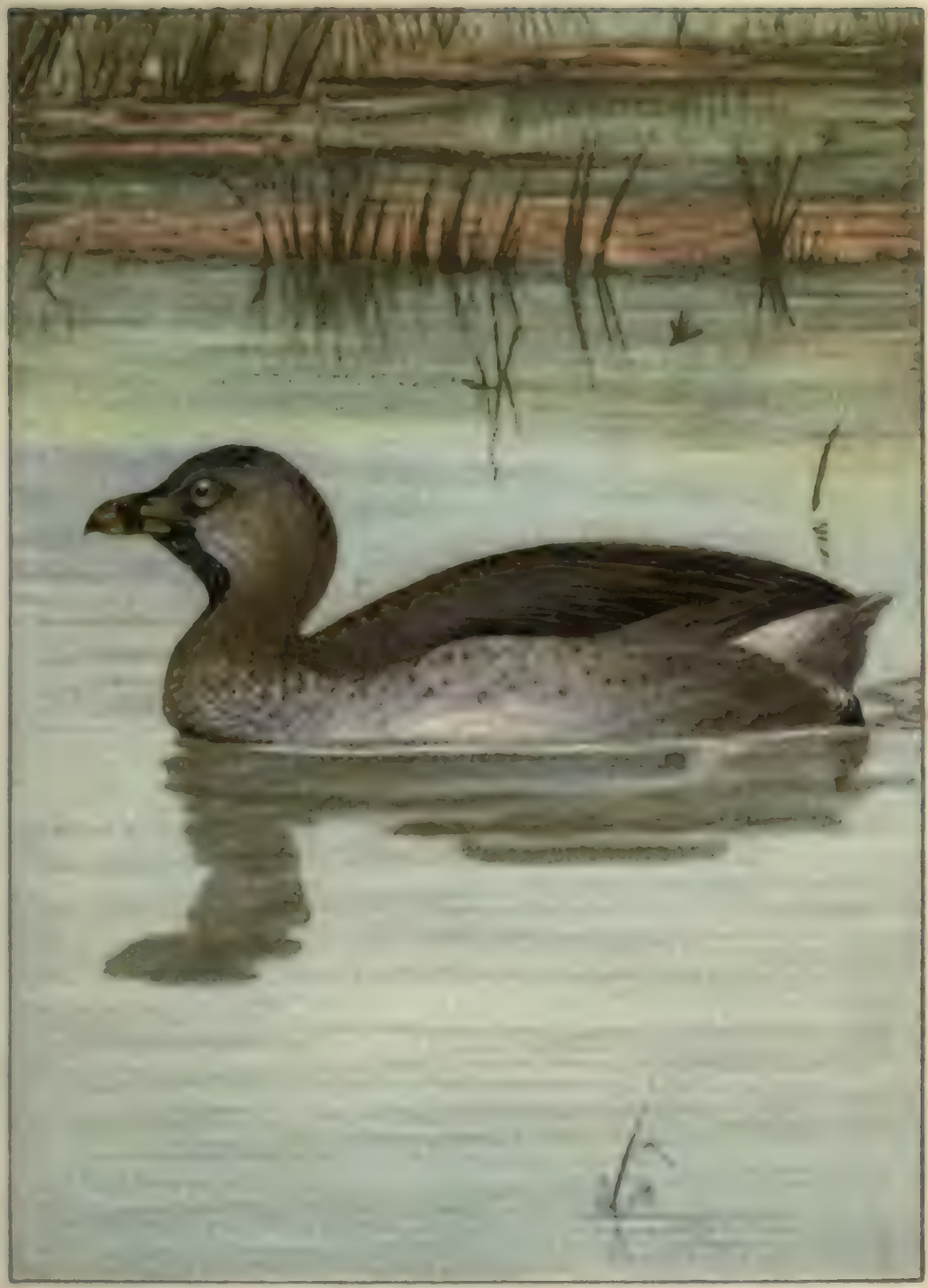

Pratr. II.

Paar 84.

PIED-BILLED GREBE.

Length, 19.60 Inches. Summer plumage, upper parts blacklsh brown; thruat and spot on blll black; fore neck browulsh, rest of under parts grayiah white. Wines plwwage, similar, but without black on throat or blll. 

It is unnecessary to discuss here the relationships of the birdlike reptiles, but, as the most convincing argument in support of the theory of the reptilian descent of birds, I present a restoration of the Archmopteryx, the earliest known progenitor of the class Aves. This restoration is

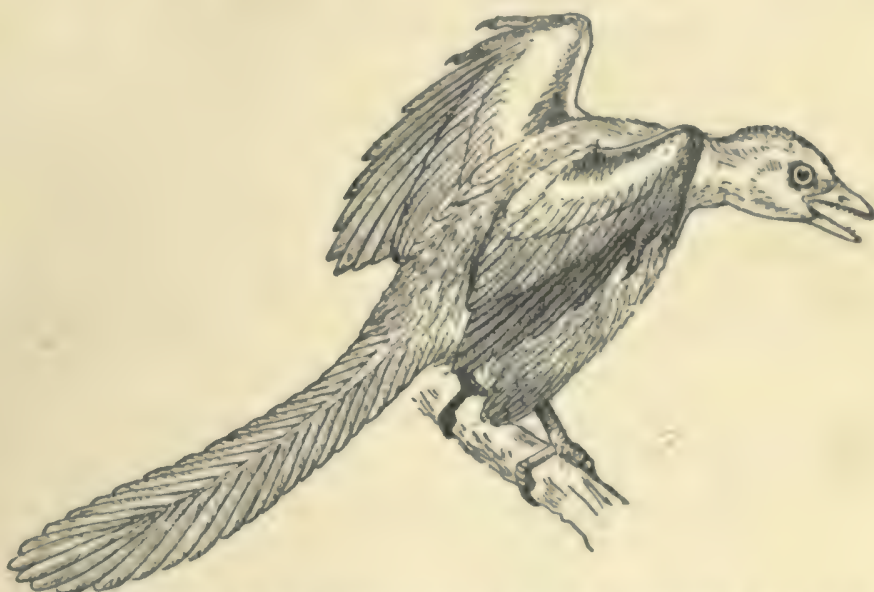

Fis. 1.-Restoration of the Archæopteryx, a toothed, reptilelike bird of the Jurassic poriod. (About $\%$ natural sizo.)

based on an examination of previous restorations in connection with a study of the excellent plates which have been published of the fossils themselres.* Two specimens have been discovered; one being now in the British Museum, the other in the Berlin Museum. They were both found in the lithographic slates of Solenhofen, in Bavaria, a formation of the Jurassic period, and, together, furnish the more important details of the structure of this reptilelike bird.

This restoration, therefore, while doubtless inaccurate

- For recent papers on the Archæopteryx see Natural Science (Macmillan Co.), vols, v-viii. 
in minor points, is still near enough to the truth to give a correct idea of this extraordinary bird's appearance.

The Archæopteryx was alout the size of a Crow. Its long, feathered tail is supposed to have acted as an aëroplane, assisting in the support of the bird while it was in the air, but its power of flight was doubtless limited. It was arboreal and probably never descended to the earth, but climbed about the branches of trees, using its large, hooked fingers in passing from limb to limb.

The wanderings of this almost quadrupedal creature must necessarily have been limited, but its winged descendunts of to-day are more generally distributed than are any other animals.* They roam the earth from pole to pole; they are equally at home on a wave-washed coral reef or in an arid desert, amid arctic snows or in the shades of a tropical forest. This is due not alone to their powers of flight but to their adaptability to varying conditions of life. Although, as I have said, birds are more closely related among themselves than are the members of either of the other higher groups of animals, and all birds agree in possessing the more important distinguishing ch tracters of their class, yet they show a wide range of variation in structure.

This, in most instances, is closely related to habits,

- On the distrihution of animals read Allen. The Gengrnphical Distribution of North Americun Mammals, Bulletin of the American Museurn of Nalural Ilistory, New York city. iv, 1802. pp. 199-244; four maps, Allen, The Gengraphicul Origin and Distribution of North American Birils considered in Relation to Faunal Areas of North America, The Auk (New York city). x. 1883. pp. 9\%-150); two maps. Merriun, The Gecugraphic Distribution of I ife in North America, with Sprecial Reference to Mummulim. I'roceedings of the Binlogical Society of Washington, vii. 1892. pp. 1-04: one map. Merrian. Laws of Temperature Control of the Gengruphic Distribution of Terrestrial Animals and P'hnts, Xational Geugraphic Muguzine (Wushington), vi, 1894, Pp. 220-238; three maps. 
which in birds are doubtless more varied than in any of the other higher animuls. Some birds, like Penguins, are so aquatic that they are practically helpless on land. Their wings are too small to support them in the air, but they fly under water with great rapidity, and might be termed feathered porpoises. Others, like the Ostrich, are terrestrial, and can neither fly nor swim. Othere still, like the Frigate Birds, are aërial. Their suiall feet are of use only in perching, and their home is in the air.

If now we should compare specimens of Pengains, Ostriches, and Frigate-birds with each other, and with such widely different forms as Hummingbirds, Woodpeckers, Parrots, and others, we would realize still more clearly the remarkable amount of variation shown by birds. This great difference in form is accompanied by a corresponding variation in habit, making possible, as before remarked, the wide distribution of birds, which, together with their size and abundance, renders them of incalculable importance to man. Their economic value, however, may be more properly spoken of under

The Relation of Birds to Man. - The relation of lirds to man is threefold-the scientific, the economic, and the resthetic. No animals form more profitable subjects for the scientist than birds. The embryologist, the morphologist, and the systematist, the philosoplic naturalist and the prychologist, all may find in them exhaustless material for study. It is not my purpose, however, to spenk here of the science of ornithology. Let us learn something of the bird in its haunts before taking it to the laboratory. The living bird can not fail to attract us; the dead bird-voiceless, motionlese - we will leave for future dissection.

The economie valne of birds to man lies in the service they render in preventing the undue increase of insects, 
in devouring small rodents, in destroying the seeds of harmful plants, and in acting as scavengers.

Loading entomologists estimate that insects cause an annual loss of at least two hundred million dollars to the agricultural interests of the United States. The statement seems incredible, but is based upon reliable statiatics. This, of course, does not include the damage done to ormamental shrubbery, shade and forest trees. But if insects are the natural enemies of vegetation, birds ure the natural enemies of insects. Consider for a moment what the birds are doing for us any summer day, when insects are so abundant that the hum of their united voices hecomes an almost inherent part of the atmosphere.

In the air Swallows and Swifts are coursing rapidly to and fro, ever in pursuit of the insects which constitute their sole food. When they retire, the Nighthawks and Whip-poor-wills will take up the chase, catching moths and other nocturnal insects which would escape day-flying lirds. The Flyeatchers lie in wait, darting from ambush at passing prey, and with a suggestive click of the bill rekurning to their post. The $\mathrm{W}$ arblers, light, active creatures, flutter about the terminal foliage, and with almost the skill of a Humminglird pick insects from leaf or blessom. The Virens patiently explore the under sides of leaven and odd nooks and corners to see that no skulker escalpes. The Woodpeckers, Nuthatches, and Creepers nftend to the tree trunks and limbs, examining carefully each inch of burk for insects' eggs and larvæ, or excavating for the ants and borers they hear at work within. On the ground the hunt is continued by the Thrushes, Sparrows, and other birds, who feed upon the innumeralle forms of terrestrial insects. Few places in which inserts exint are neglected; even some species which pass their earlier stages or entire lives in the water are preyed upon by aquatic birds. 


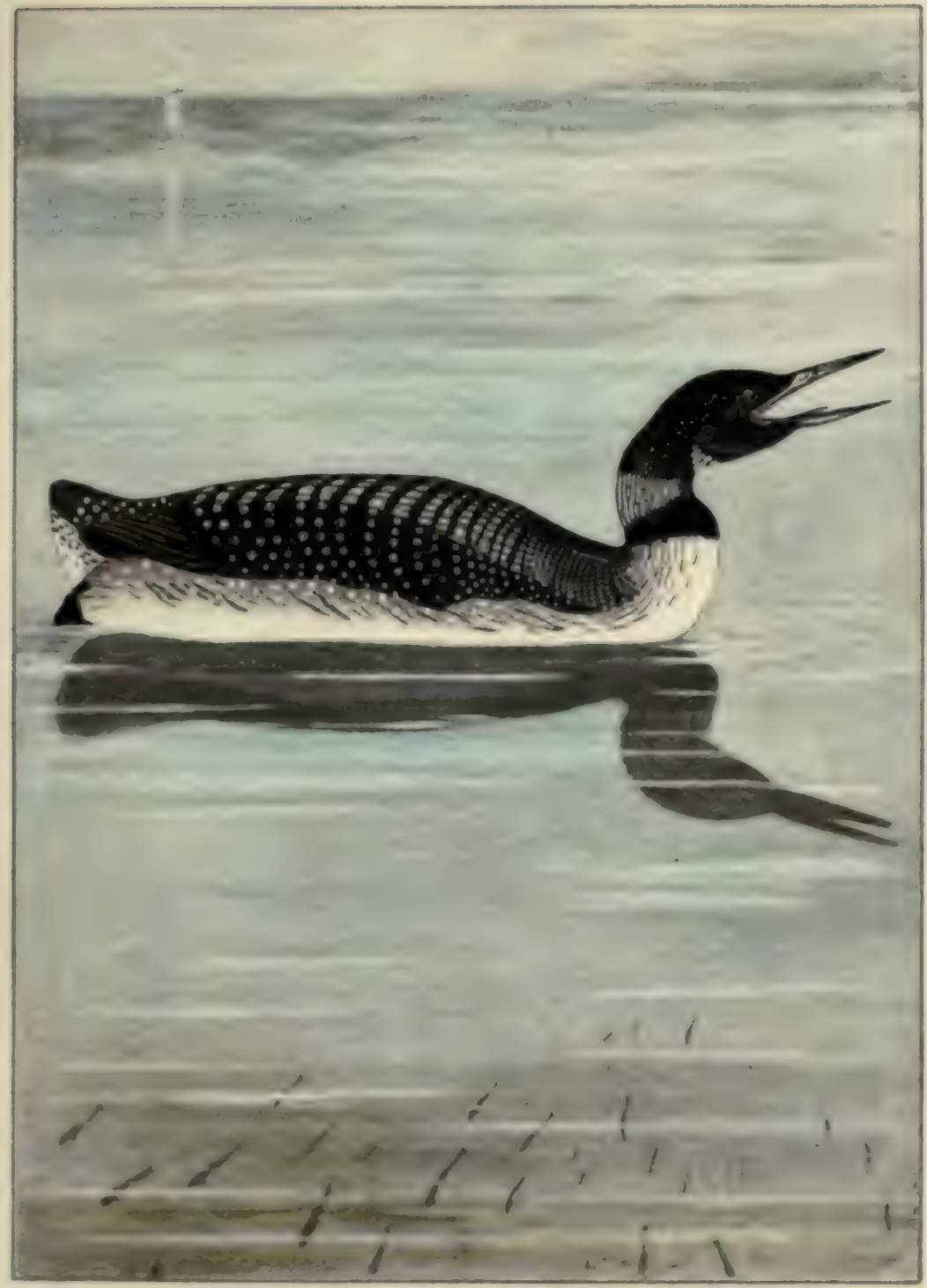

PUATE III.

LOON.

PaGe 85.

Length, 3200 Inches. Sumomer plumage, upper parts and fore neck black and white; breast and belly white. Winter plumage, upper parts dark graylsh; under parts white. 

Birds digest their food so rapilly, that it is difficult to estinate from the contents of a bird's stomach at a given time how much it eats during the day. The stomach of a Yellow-billed Cuckoo, shot at six o'cloek in the morning, contained the partially digested remains of forty-three tent caterpillars, but how many it would have eaten before night no one can say.

Mr. E. II. Forbush, Ornithologist of the Board of Agriculture of Massachusetta, states that the stomachs of four Chickadees contained one thousand and twentyeight eggs of the cankerworm. The stomachs of four other birds of the same species contained about six hundred eggs and one hundred and fire female moths of the cankerworm. The arerage number of eggs found in twenty of these moths was one hundred and eighty-five; and as it is estimated that a Chickaclee may eat thirty female cankerworn moths per day during the twenty-five days which these moths erawl up trees, it follows that in this period each Chickadee would destroy one hundred and thirty-eight thousand seren hunIrel and fifty eggs of this noxious insect.

Professor Forbes, Director of the Illinois State Laboratory of Natural History, found one hundred and serenty-five larva of Bibio-a fly which in the larval stage feeds on the roots of grass-in the stomach of a single Robin, and the intestine contained probably as many more.

Many additional cases could be cited, showing the intimate relation of birds to insect-life, and emphasizing the necessity of protecting and encournging these little. appreciated allies of the agriculturist.

The service rendered man by birds in killing the small rodents so destructive to crops is performed hy IIawks and Owlo-birds the uninformed farmer con. siders his enemies. The truth is that, with two excep. 
tions, the Sharp-shinned and Cooper's Hawk, all our commoner Ilawks and $O$ wls are beneficial. In his exhaustive study of the foods of these birds Dr. A. K. Fisher, Assistant Ornithologist of the United States Department of Agriculture, has found that ninety per cent of the food of the Rel-shouldered Hawk, commonly called "Chicken Hawk" or "Ilen Hawk," consists of injurious mammls and insects, while two hundred castings of the I harn Owl contained the skulls of four hundred and fiftyfour small mammals, no less than two hundred and twentyfive of these being skulls of the destructive field or meadow mouse.

Still, these birds are not only not protected, but in some States a price is actually set upon their heads! Dr. C. Hart Merriam, Ornithologist and Mammalogist of the United States Department of Agriculture, has estimated that in offering a bounty on Hawks and Owls, which resulted in the killing of over one hundred thousand of these hirds, the State of Pennsylvania sustained a loss of nearly four million dollars in one year and a half!

As destroyers of the seeds of harmful plants, the good done ly birds can not be overestimated. From late fall to early spring, seeds form the only food of many birds, and every keeper of cage-lirds can realize how many a bird may eat in a day. Thus, while the Chickadees, Nuthatehes, Woolpeckers, and some other winter birds are ridding the trees of myrials of insects' eggg and larvæ, the granivorous birds are reaping a crop of seeds which, if left to germinate, would cause a heavy loss to our agricultural interest8.

As seavengers we understand that certain birds are of value to us, and therefore we protect them. Thus the Vultures or Buzzards of the South are protected both by law and pullie sentiment, and as a result they are not only exceedingly abundant, but remarkably tame. But 
we do not realize that Gulls and some other water birds are also beneficial as scavengers in eating refuse which, if left flonting on the water, would often be east ashore to desay. Dr. George F. Guumer, of Yucatun, tells me that the killing of immense numbers of Herons and other littoral lirels in Yucatan has been followed by an increase in human mortality among the inhabitants of the coast, which he is assured is a direct result of the destruction of birds that formerly assisted in keeping the beaches and bayous free from decaying animal matter.

Lack of space forbids an adequate treatment of this subject, but reference to the works and papers mentioned below * will support the statement that, if we were deprived of the services of birds, the earth would soon become uninhabitable.

Nevertheless, the fenthered protectors of our farms and gardens, plains and forests, require so little encouragement from us -indeed, ask only tolerance-that we accept their services much as we do the air we brenthe. We may be in debt to them past reckoning, and still be unaware of their existence.

But to appreciate the beauty of form and plumage of

- Notes on the Nature of the Fond of the Birts of Nebraska. hy S. Aughey: First Annual Rmprt of the Lnited Stutes Fininmulngical Commission for the Year 1877. Appendix ii, pp. 13-62. The Food of Birds, by S. A. Forhes: Bulletin No 3. Illinois State I anhorntory of Natuml II istory. 1880. pp. 80-148. The Regulntive Action of Birls upon Insect Dscillutinns, ly S. A. Forbes, ihid.. Bulletin Nn, 6. 1883, pp. 8-32. Fennomie Relations of Wisconsin Rirds. by F. H. King: Wisennain fienlogieal survey, vol. i. 1882. pp. 441-610. Repmrt nn the Birls of Pennsvlvania, wilh Special Reference in the Fond flatits. baerl on nrer Four 'Tlunusand sinmneh Fixaminations, hy R. П. Warren: Harrialurg. F. K. Merers. State Printer. Inrge 8ro. pp. 484. plates 100. The English Sparrow in Sorth America. especially in its Relation in A grimlture. prepuresl under the Direction of C. Iart Merriam, by Walter 13. Barmwa; Bulletin No. 1. Division of Eennomic Ornithelogy and Mammalogy of the C'nited States Department of Agricul- 
birds, their grace of motion and musical powers, we must know them. Then, too, we will be attracted by their high mental development, or what I have elsewhere spoken of as "their human attributes. Man exhibits hardly a trait which he will not find reflected in the life of a bird. Love, hate; courage, fear ; anger, pleasure ; vanity, modesty; virtue, vice; constancy, fickleness; generosity, selfishness; wit, curiosity, memory, reason-we may find them all exhibited in the lives of birds. Birds have thus become symbolic of certain human characteristics, and the more common species are so interwoven in our art and literature that by name at least they are known to all of us."

The sight of a bird or the sound of its voice is at all times an event of such significance to me, a source of such unfailing pleasure, that when I go afield with those to whom birds are strangers, I am deeply impressed by the comparative barrenness of their world, for they live in ignorance of the great store of enjoyment which might be theirs for the asking.

I count each day memorable that brought me a new friend among the birds. It was an event to be recorded in detail. A creature which, up to that moment, existed

ture, 1889. The Hawks and Owls of the Unifed States in their Relation to Agriculture prepared under the Direction of C. Inart Merriam. by A. K. Fisher: Bulletin No. 3. ibid., 1893. The Common Crow of the United States, by Walter B. Barrows and E. A. Schwarz: Bulletin No. 6, ibitl., 1895. Preliminary Report on the Food of Wondpeckers, by F. E. I. Beal; Bullet in No. 7, ibid., 1895. (See also other papers on the foxd of birds in the Annual Report and Yeartronk of the United Siates Department of Agriculture.) Birds as Protectons of Orchards, by F. H. Forbush; Bulletin No. 3, Massachusptes State Board of Agriculture, 1895. pp. 20-32. The Crow in Massachusetts, by I\%. II. Forbush: Bulletin No. 4, ibid., 1896. How IBirds affect the Farm and Garilen, by Florence A. Merriam; roprinted from "Forost und Stream," 1800, 16mo, pp. 31. Price, 5 cents. 


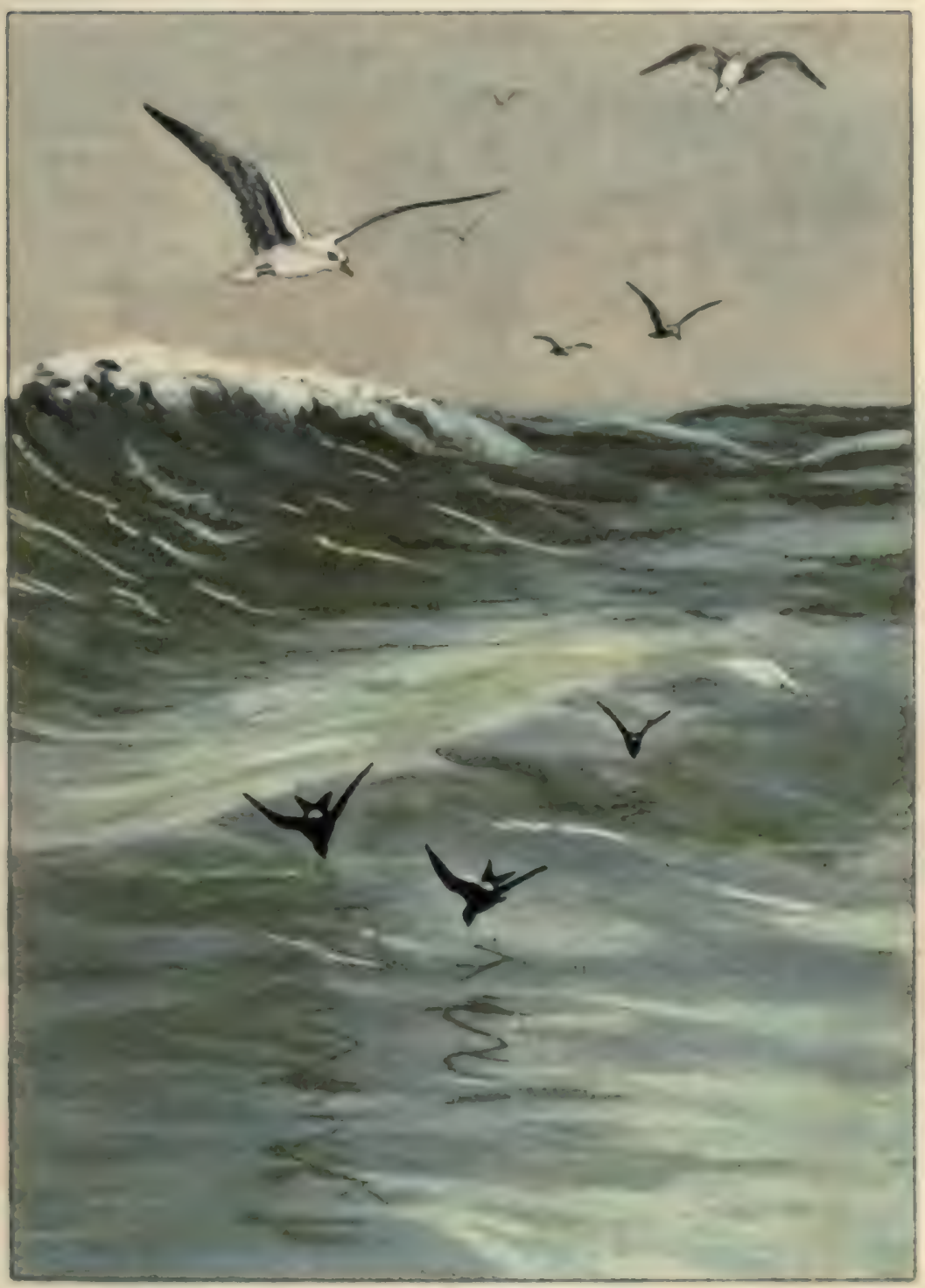

Punte IV.

HERRING GULT.

PAars 86, 88.

Length, 2400 Inches. Adw/t, back and wings pearl-gray; end of primarles marked with black; rest of plumage white. Young, dark grayish, primartes and tail brownlah black.

\section{PETREIS.}

Length, 7.50 inches. Black, upper tall-coverts white. 

for me only as a name, now became an inlabitant of my woods, a part of my lifo. With what a new interest I got down my books again, eagerly reading every item concerning this new friend; its travels, habits, and notes; comparing the observations of others with what were now my own!

The study of birds is not restricted to any special season. Some species are always with us. Long after the leaves huve fallen and the fields are bare and brown, when insect voices are hushed, and even some mammals are sleeping their winter sleep, the cheery Juncos flit about our doorstep, the White-throats twitter cozily from the evergreens, Tree Sparrows chatter gayly over their breakfast of seeds, and Crows are calling from the woods. Birds are the only living creatures to be seen; what a sense of companionship their presence gives; how desolate the earth would scem without them!

The ease with which we may become familiar with these feathered neighbors of ours robs ignorance of all excuses. Once aware of their existence, and we shall see a bird in every bush and find the heavens their pathway. One moment we may admire their beauty of plumage, the next marvel at the ease and grace with which they dash by us or circle high overhead.

But birds will appeal to us most strongly through their songs. When your ears are attuned to the music of birds, your world will he transformed. Birds' songs are the most eloquent of Nature's voices: the gay carol of the Grosbeak in the morning, the dreamy, midday call of the Pewee, the vesper hymn of the Thrush, the clanging of Geese in the springtime, the farewell of the Bluebird in the fall-how clearly each one expresses the sentiment of the hour or season!

Having learned a bird's language, you experience an increased feeling of comradeship with it. You may even 
share its emotions as you learn the significance of its notes. No one can listen to the song of the Mockingbird without being in some way affected; but in how many bearts does the tink of the night-flying Bobolink find a response? I never hear it without wishing the brave little traveler Godspeed on his long journey.

As time passes you will find that the songs of birds bring a constantly increasing pleasure. This is the result of association. The places and people that make our world are ever changing; the present slips from us with growing rapidity, but the birds are ever with us.

The Robin singing so cheerily outside my window sings not for himself alone, but for hundreds of Robins I have known at other times and places. His song recalls a March evening, warm with the promise of spring; May mornings, when all the world seemed to ring with the voices of birds; June days, when cherries were ripening; the winter sunlit forests of Florida, and even the snowcapped summit of glorious Popocatepetl. And so it is with other birds. We may, it is true, have known them for years, but they have not changed, and their familiar notes and appearance encourage the pleasant self-delusion that we too are the same.

The slender saplings of earlier years now give widespreading shade, the scrubby pasture lot has become a dense woodland. Boyhood's friends are boys no longer, and, worst of all, there has appeared another generation of hoys whose presence is discouraging proof that for us youth has past. Then some May morning we hear the Wood Thrush sing. Has he, too, changed? Not one note, and as his silvery voice rings through the woods we are young again. No fountain of youth could be more potent. A hundred incidents of the long ago become as real as those of yesterday. And here we have the secret of youth in age which every venerable natural- 
ist I have ever met has convincingly illustrated. I could name nearly a dozen, living and dead, whom it has been my valuod privilepe to know. All had passed the allotted threescore and ten, and some were over fourscore. The friends and associates of their earlier days had passed away, and one might imagine that they had no interest in life and were simply waiting for the end.

But these veterans were old in years only. Their hearts were young. The earth was fair; plants still bloomel, and birds sang for them. There was no idle waiting here; the days were all too short. With what boyish ardor they told of some recent discovery; what inspiration there was in their enthusiasm !

So I say to you, if you would reap the purest pleasures of youth, manhood, and old age, go to the birds and through them be brought within the ennobling influences of Nature. 


\section{CHAPTER II.}

THE LIVING BIRD.

Factors of Evolution.-If while in the fields we observe birds with an appreciative eye, we shall soon be impressed with the great diversity shown in their structure and habits. The Fish Hawk plunges from the air into the water and grasps its prey with merciless talons. The Hummingbird daintily probes a flower. The Woodpecker climbs an upright trunk, props itself with its stiff, pointed tail-feathers, while with its chisel-shaped bill it excavates a grub and then impales it with its spearlike tongue. These birds tell us a wonderful story

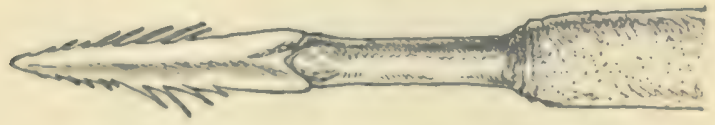

Fro. 2.- End of spearlike tongue of Pileated Woodpecker. (Much enlarged.)

of adaptation to the conditions of life, and, knowing that they have descended from a common ancestor, we ask, "Why do they now differ so widely from one another?" Biologists the world over are trying to satisfactorily answer this question, and it is impossible for me to even mention here all the theories which they have advanced. However, some knowledge of the most important ones is essential if you would study the relation between the bird and its haunts and habits. The Darwin-Wallace theory of Natural Selection, in more or less 


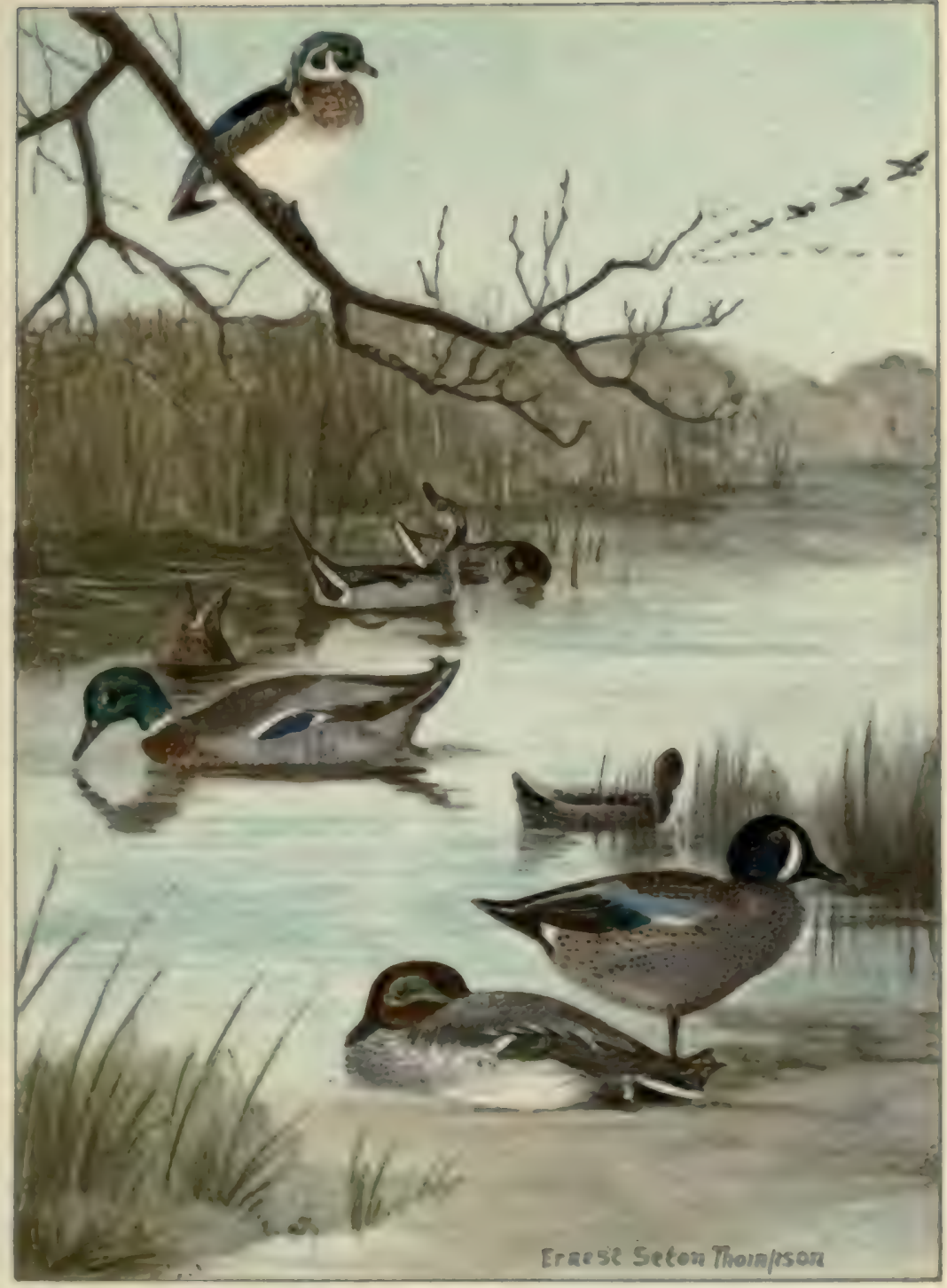

Prate V.

1 WOOD DOCK.

2 PINTAIL.

3 MALLARD.
15

- Page 80.

4 GREEN-WINGED TEAI.

5 BLUE-WINGED TEAL.

6 CANADA GEESE. 

modified forms, is accepted by most naturalists. As originally presented, it assumed that the continued existence of any animal depended upon its adaptation to its manner of life. Among a large number of individuals there is much variation in size, form, and color. Some of these variations might prove favorable, others unfaromble. Those which were favorable would give to the mdivichal possessing them an advantage over its fellows, and, by what is termed Natural Selection, it would be preserved and its favorable characters transmitted to its descendants. But the less fortunate individuals, which lacked the favorable variation, would be handicapped in the race for life and be less likely to survive.

Without necessarily opposing this theory, the followers of Darwin's predecessor, Lamarck, attach more imjortance to the direct action of environment on the animal-that is, the influence of climate, food, and habit. The effect of the first two I will speak of in treating of color; the last we may usc to illustrate the difference in these two theories by asking the question, "Is habit due to structure, or is structure the result of habit ?" Has Nature, acting through natural selection, preserved those variations which would best fit a bird to occupy its place in the world, and are its habits the outcome of the characters thus acquired, or have the changes which during the ages have occurred in a bird's home, forcing it to alter its habits, been followed by some consequent change in structure, the result of use or of disuse? For my part, I answer "Yes" to both questions, and turn to our stiff-tailed, spear-tongued Woodpecker to explain my reply. I can readily understand how the shape of these tail-feathers is the result of habit, for the same or similar structure exists among many birds having no close relationship to one another, but all of which agree in their peculiar use of the tail as a prop; the Creep- 
ers, Woodhewers, and Swifts, even some Finches and the Bobolink, that use their tail to support them when perched on swaying reeds, have the feathers more or less pointed and stiffened. Furthermore, this is just the result we should expect from a habit of this kind. But

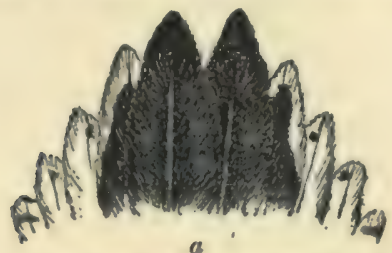

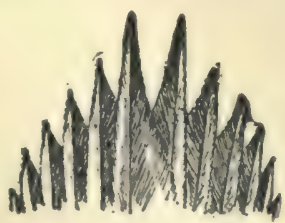

$b$

FIa. 8. Tip of tail of $(a)$ Downy Woodpecker and of (b) Brown Creeper, to show the poinied shape in tails of cresping birds of different fauilies. (Natural size.)

I do not understand how the Woodpecker's spear-tipped tongue could have resulted from the habit of impaling grubs, and in this case I should be inclined to regard structure as due to a natural selection which has preserved favorable variations in the form of this organ.

I have not space to discuss this subject more fully, but trust that enough has been said to so convince you of the significance of habit, that when you see a bird in the bush it will not seem a mere automaton, but in each movement will give you evidence of a nice adjustment to its surroundings. Remember, too, that evolution is a thing of the present as well as of the past. We may not be able to read the earlier pages in the history of a species, but the record of to-day is open to us if we can learn to interpret it.

This may be made clearer, and the importance of a study of habit be emphasized, if I briefly outline the relation between the wings, tail, feet, and bill of birds and the manner in which they are used. We are in the field, not in the dissecting room; our instrument is a field glass, not a scalpel, and in learning the functions of these four 
organs we shall direct our attention to their external form rather than their internal structure.

The Wing.-Birds' wings are primarily organs of locomotion, but they are also used as weapons, as musical instruments, in expressing emotion, and they are some-

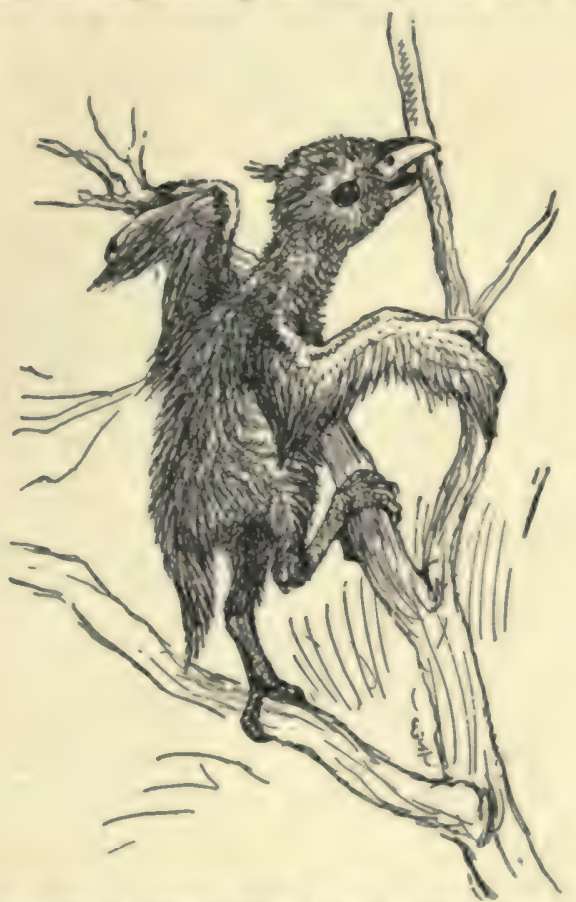

Rt3. 4-Young Hoatzin, showing use of hooked fingers in climbing. (Aftes Lucas.)

times the seat of sexual adornment. As an organ of locomotion the wing's most primitve use is donbtless for climbing. Gallinules, for instance, have a small spur on the wrist or "bend of the wing," and the young birds nse it to assist their progress among the reeds. A more striking instance of this nature is shown by that singular South American bird, the Hoatzin (Opisthocomus cris- 
tatus). The young of this bird have well-developed claws on the thumb and first finger, and long before they can fly they use them as aids in clambering about the bushes, very much as we may imagine the Archæopteryx did. In the adult these claws are wanting.

Some eminently aquatic birds, as Grebes and Penguins, when on land, may use their wings as fore legs in scrambling awkwardly along; while some flightless birds, for example, the Ostrich, spread their wings when running.

But let us consider the wing in its true office, that of an organ of flight, showing its range of variation, and

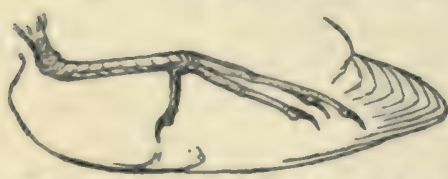

Fro. 5.-Short, rounded wing and large foot of Little Black Ruil, a terrestrial bird. ( $\% / 3$ natural aize.) finally its degradation into a flightless organ. Among flying birds the spread wings measure in extent from about three inches in the smallest Hummingbird to twelve or fourteen feet in the Wandering Albatross. The relation between shape of wing and style of flight is so close that if you show an ornithologist a bird's wing he can generally tell you the character of its owner's flight. The extremes are shown by the short-winged ground birds,

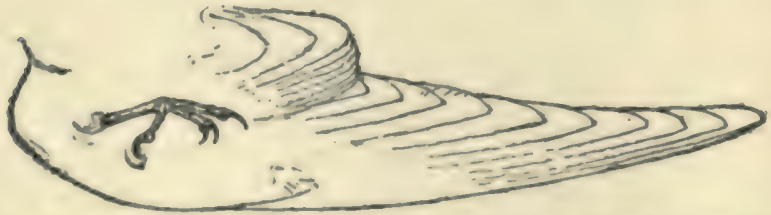

Fro. 6.-Long, pointed wing and small foot of Tree Swallow, an aø̊rial bird. ( $\%$ nutural size.)

such as Rail, Quail, Grouse, certain Sparrows, etc., and long-winged birds, like the Swallows and Albatrosses. There is here a close and, for the ground-inhabiting 


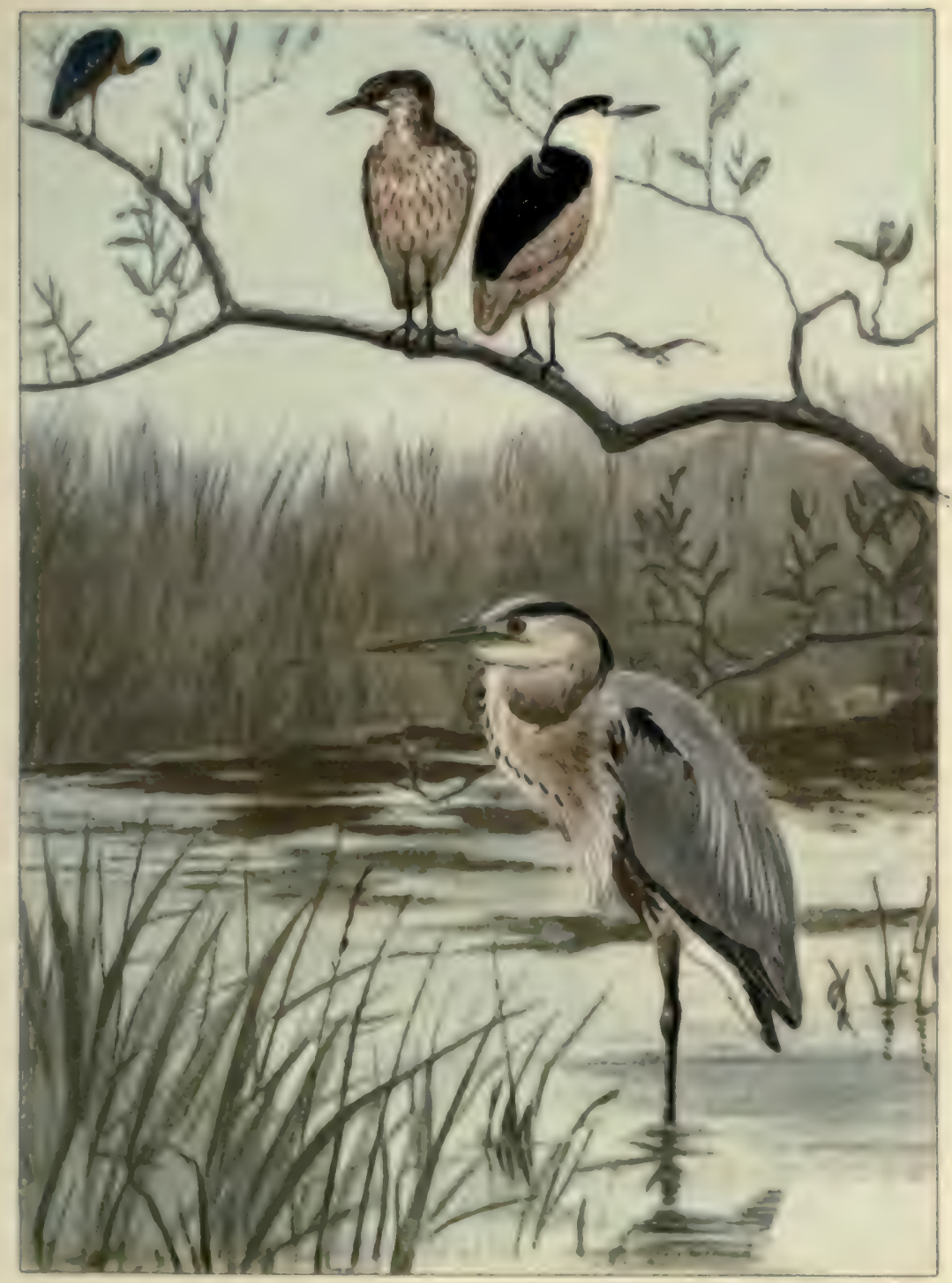

Puatr VI.

Paer 90.

ITTTLE GREEN HERON. BLAOK-OROWNED NIGHT HERON. (Lougth, r7.00 incles.)

(YOUNe AND ADULT.)

(Length, 24.00 incies.)

GREAT BLUE HERON.

(Lengeh, 45.00 inches.) 

birda, important relation between form and habit. Many terrestrial species rely on their dull, protective covering to escape olservation, taking wing only when langer is so near that it is necessary for them to get under way at once. Consequently, Quail, Partridges, and (irouse, much to the anateur sportsman's discomfiture, spring from the ground as though thrown from a catapult, and reach their highest speed within a few yurds of the starting point, while the Albatross is obliged to face the wind and run some distance over the ground or water before slowly lifting itself into the air. There, however, it can remain for hours or even days without once alighting.

The Frigate Bird, or Man-o'-War Bird, has a body scarcely larger than that of a chicken, but its tail is one foot and a half in length, and its wings measure seven to

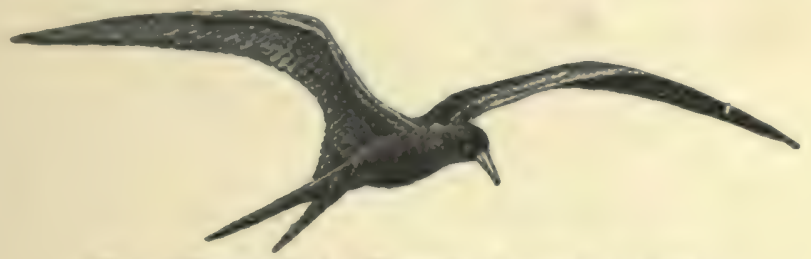

Fro. 7.-Frigate Bird. (Expanse of wings, 7 to 8 feet.)

eight feet in extent. Having this enormous spread of sail, its flight is more easy and graceful than that of any living bird. I have seen hundreds of these birds floating in the air, facing the wind, without apparent change of position or the movement of a pinion, for long intervals of time.

From this extreme development of the wing as a flight-organ, let us turn to those birds who have not the power of flight. The Ostrich, Rhea, Emu, and Cassowary are familur representatives of this group. It is generally believed that these birds have lost the power 
of flight, and that as their wings, through disuse, became functionless, their running powers correspondingly increased. This, however, is theory, but there are birds which have become flightless through some apparently known cause. They may be found among such widely separated families as Grebes, Auks, Ducks, Rails, Gallinnles, Pigeons, and Parrots.

One of the characteristic water birds of our North Atlantic coasts is the Razor-billed Auk. It is a striçtly aquatic species, nearly helpless on land, which, as a rule, it visits on.y when nesting. Its egg is laid in the crevice of a rocky cliff, frequently at some height from the sea. During the winter it migrates southward as far as Long Island. Flight is therefore a necessary faculty, and we find the bird with well-developed wings, which it uses effectively. We can, however, imagine conditions under which it would not be necessary for the Razor-bill to fly. It might become a permanent resident of isolated islands, laying its egg on accessible beaches. Already an expert diver, obtaining its food in the water, it would not be obliged to rise into the air, and, as a result of disuse, the wings would finally become too small to support it in aërial flight, though fully answering the purpose of oars.

Apparently this is what has happened in the case of the Razor-billed Auk's relative, the flightless, extinct Great Auk. The Razor-bill is sixteen inches long and its wing measures eight inches, while the Great Auk, with a length of thirty inches, has a wing only five and three fourths inches in length. Aside from this difference in measurements these birds closely resemble each other. So far as we are familiar with the Great Auk's habits, they agreed with those of the hypothetical case I have just mentioned, and we are warranted, I think, in assuming that the bird lost the power of flighe through disuse of its wings. 
In antarctic seas we find the arctic Auks replaced by the Penguins, a group in which all the members are Alightless. They are possessed of remarkal,le arguatic

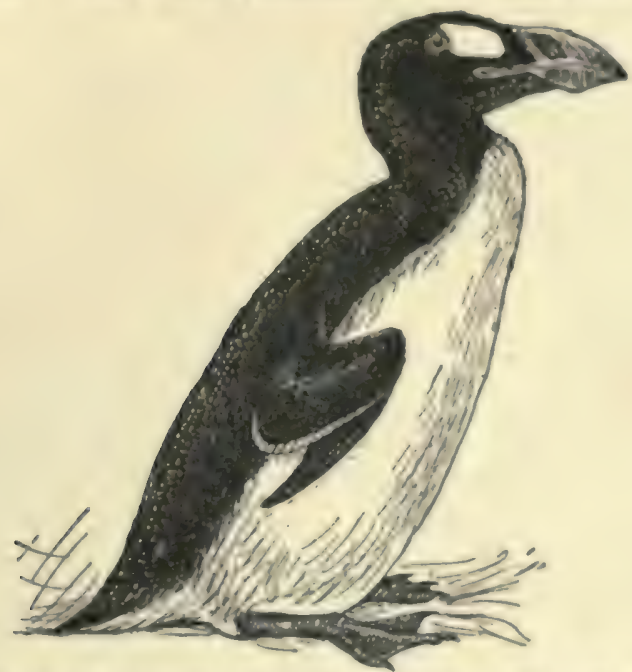

Fro. 8. -Grent $\Lambda$ uk, showing relatively smull wing. (Length of bird, 20 inches; of wing, 575 inches.)

powers, and can, it is said, outswim even fish. They nest only on isolated islands, where they are not exposed to the attack of predaceous mammals.

Among Grehes and Ducks we have illustrations of the way in which swimming birds may become temporarily flightless. With most land-inhabiting birds flight is 80 inportant a faculty that any injury to the wings is apt to result fatally. It is necessury, therefore, that the power of flight shall not he impaired. Consequently, when molting, the wing-feathers are shed slowly and symmetrically, from the middle of the wing both inwardly and outwardly; the new feathers appear 80 quickly that at no time are there more than two or three quills missing from either wing. But the 
aquatic Grebes and Ducks, protected by the nature of their haunts and habits, lose all their wing-feathers at once, and are flightless until their new plumage has grown.

It might then be supposed that permanently flightless forms would be found among the Grebes and Ducks. But these birds are generally migratory, or, if resident, they usually inhabit bodies of fresh water where local conditions or droughts may so affect the food supply that change of residence would become necessary. However, on Lake Titicaca, Peru, there actually is a Grebe which has lived there long enough to have lost the use of its wings as flight-organs.

Rails are such ground-lovers, and fly so little, that we should expect to find flightless forms among them when the surroundings were favorable for their development. In New Zealand, that island of so many flightless birds, the requirements are evidently fulfilled, and we have the flightless Wood Hens. Here, too, lives the flightless Gallinule, Notornis, and in this family of Gallinules, birds not unlike Coots, there are at least four flightless species inhabiting islands-one in the Moluccas, one in Samoa, one on Tristan d'Acunha, and one on Gough Island. The last two islands are about fifteen hundred miles from Cape Good Hope, and have evidently never been connected with a continent. There seems little reason to doubt, therefore, that the ancestors of the Gallinules now inhabiting these islands reached them by the use of their wings, and that these organs have since become too small and weak to support their owners in the air. Other cases might be cited; for instance, the Dodo of Mauritius among Pigeons, and the Kakapo (Stringops) of New Zealand among Parrots; but if the illustrations already given have not convinced you that disuse of the wings may result in loss of tight, let 


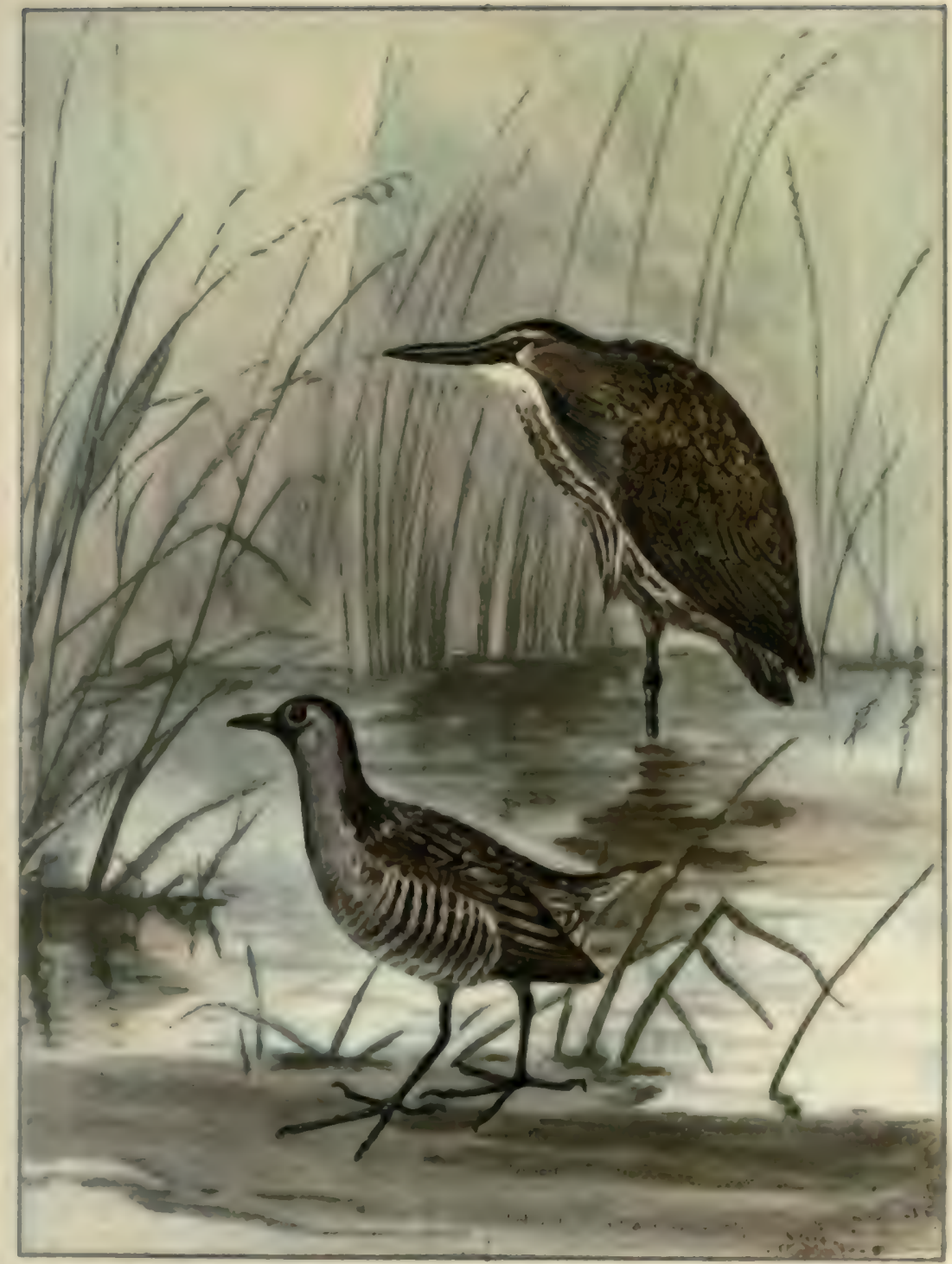

PLati VII.

PAans 98, 94.

\section{AMERICAN BITTERN.}

Length, 2800 Inchen A black streak on neck; body brown and buf; primaries slate-color.

\section{BORA.}

Length, 8.50 inches. Adull, upper parts olive-brown, bleck, and white; throat and face black, breast slate, belly white, flanks black and whlte. Young, similar, but face, throat, and breast white, washed with brownish. 

me take you finally to the poultry yard, where in the waddling Duck you will see an undeniable instance of degeneration.

As the sent of sexual characters the wing is sometimes most singularly developed or adorned. The males of the Argus Pheasant and Pennant-winged Nightjar have certain feathers enormously lengthened; the Stand. ard-hearer has white plumes growing from the wing; and there are many other cases in which the wing presents sexual characters, not alone through display, but also by nse as a musical organ. I do not refer to the whistling sound made by the wings of flying Doves or Ducks, or the humming of Hummingbirds, but to sounds voluntarily produced by birds, and evidently designed to answer the purpose of song.

A simple form of this kind of "music" is shown by the cock in clapping his wings before crowing, in the "drumming" of Grouse, or in the "booming" of Nighthawks, as with wings set they dive from a height earthward. The male Cassique (Oxtinnps) of South America, after giving voice to notes which sound like those produced by chafing trees in a gale, leans far forward, spreads and raises his large orange and black tail, then vigorously claps his wings together over his bsck, making a noise which so resembles the cracking of branches that one imagines the birds learned this singular performance during a gale.

The hirls mentioned thus far have no especial wing structure beyond mither stiffened fenthers; but in the Woolcock, some Paradise-birds and Flycatchers, Guans, Pipras, and other tropical birds, certain wing-feathers are singularly modified as musical instruments. Sometimes the outer primaries are so narrowed that little but the shaft or midrib is left, as in both sexes of the Woodcock, when the rapid wing-strokes are accompanied by a 
high, whistling sound. In other cases the shafts of the wing-feathers may be much enlarged and horny, when

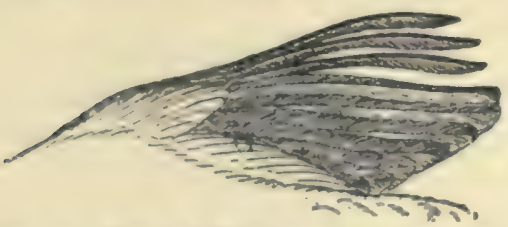

Fr6. 9.-Wing of Woodcock, showing three outer attenuato feathers. $(1 / 2$ natural ตize.) the bird makes a singular snapping sound in flight.

If you recall the supplicating manner of a young bird as with gently fluttering wings it begs for food, you will recognize one of several ways in which the wings may express emotion. Birds also threaten with their wings, as any hen with chicks will testify, and from this

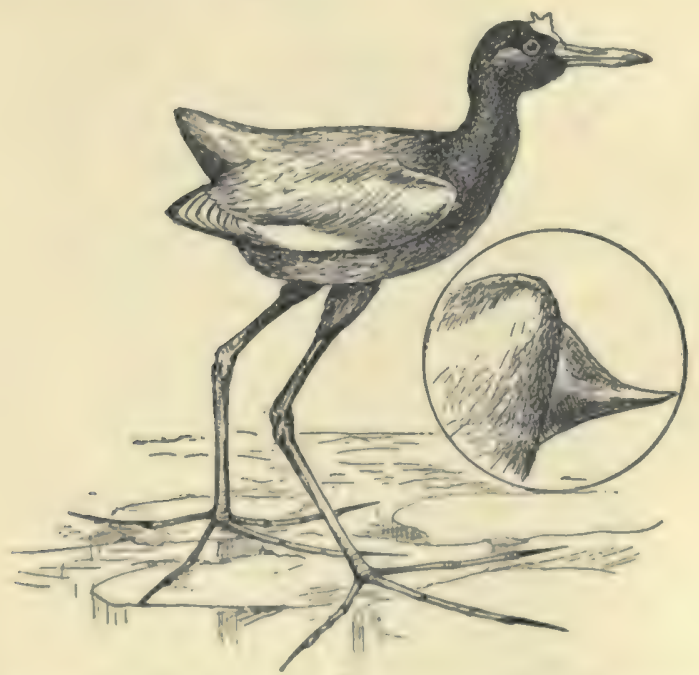

Fit. 10.-Jacana, showing spur on wing (natural size) and elongated toes (1/8 natural sizo).

gesture to the actual delivery of a blow is but a step. Swans, Pigeons, and Chickens can deal forcible blows with their wings. Screamers, Lapwings, and Jacanas 
have formidable spurs on their wings, which they are supposel to use in combat.

The Tail.-Except when sexually dereloped; the shape of the tail is largely governed by the character of its owner's flight. Male Lyre-birds, Pheasants, Fowls, II umminglirds, and many others furnish well-marked instances of the tail as a sexual character. Indeed, as the least important to the lird of the four external organs we are speaking of, the tail is more often sexually molifiel than any of the other three.

The main office of the tail, however, is mechanical, to act as a rudder in flight and a "balancer" when perching. Short-tailed birds generally fly in a straight course, and ean not make sharp turns, while long-tailed birds can pursue a most erratic course, with marrelous ease and grace. The Grebes are practically tailless, and their flight is comparatively direct, but the Swallow-tailed Kite, with a tail a foot or more in length, can dash to right or left at the most abrupt angle.

Among tree-creeping birds, which always climb upward, the tail is used as a brace or prop. This character, as has been suid, is possessed by all Woodpeckers, by the quite different Woodhewers of South Ameriea, the Brown Creepers of temperate regions, and other birds (see Figs. 3 and 4).

The two middle feathers in the tail of the Motmot, of the American tropics, end in a racket-shaped disk, the result of a unique habit. Similarly shaped feathers are found in the tails of some Hummingbirds and Old World Kingfishers, but in the Motmot this peculiar shape is due to a self-inflicted mutilation. The newly grown feathers, as shown in the accompanying figure, lack the terminal disk, but as soon as they are grown, the birds begin to pick at the barbs, and in a short time the shaft is denucled, in some species for the space of an inch, in others for as much as two inches. 
This singular habit is practiced by numerous species of Motmots, ranging from Mexico to Brazil. It is therefore of undoubted age, and we can only speculate upon its use and origin. Young birds from the nest, reared
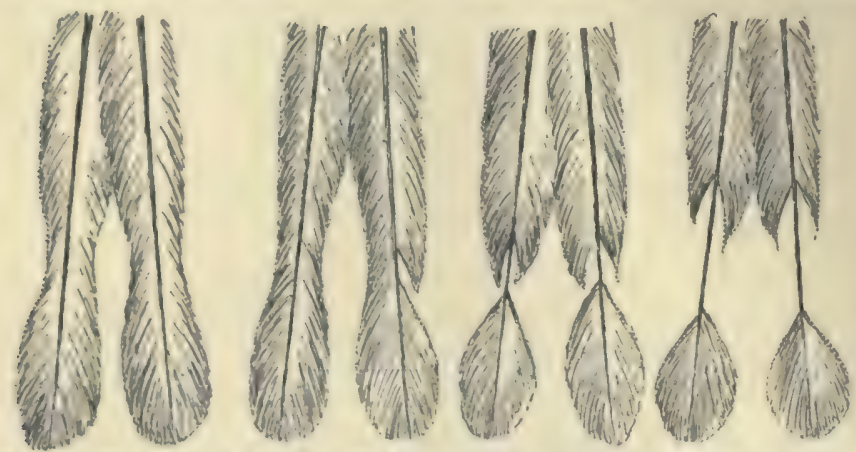

Fro. 11.-Central tail-feathers of Motmot (Momotus subruffacens), showing newly grown feathers (at the left) and results of self-inflicted mutilution.

in confinement where they were isolated from others of their kind, trimmed their tail-feathers soon after they were grown.*

The habit, therefore, is inherited, but the mutilation, although it has doubtless been practiced for countless generations, has not become inherent, unless we consider the constriction in the vane of the feather at the place where it is to be trimmed an indication of inheritance.

The Motmot gesticulates with its tail in a remarkable manner, swinging it from side to side, so that it suggests the pendulum of a clock, or sweeping it about in circles with a movement which reminds one of a bandmaster flourishing his baton. We shall find in other species, also, that the tail, more than any other organ, is used to express emotion. Recall its twitching and wagging; how it is nerrously spread or "jetted," showing the white

* See ('herrie, The Auk (New York eity), vol. ix, 1842, p. 322. 


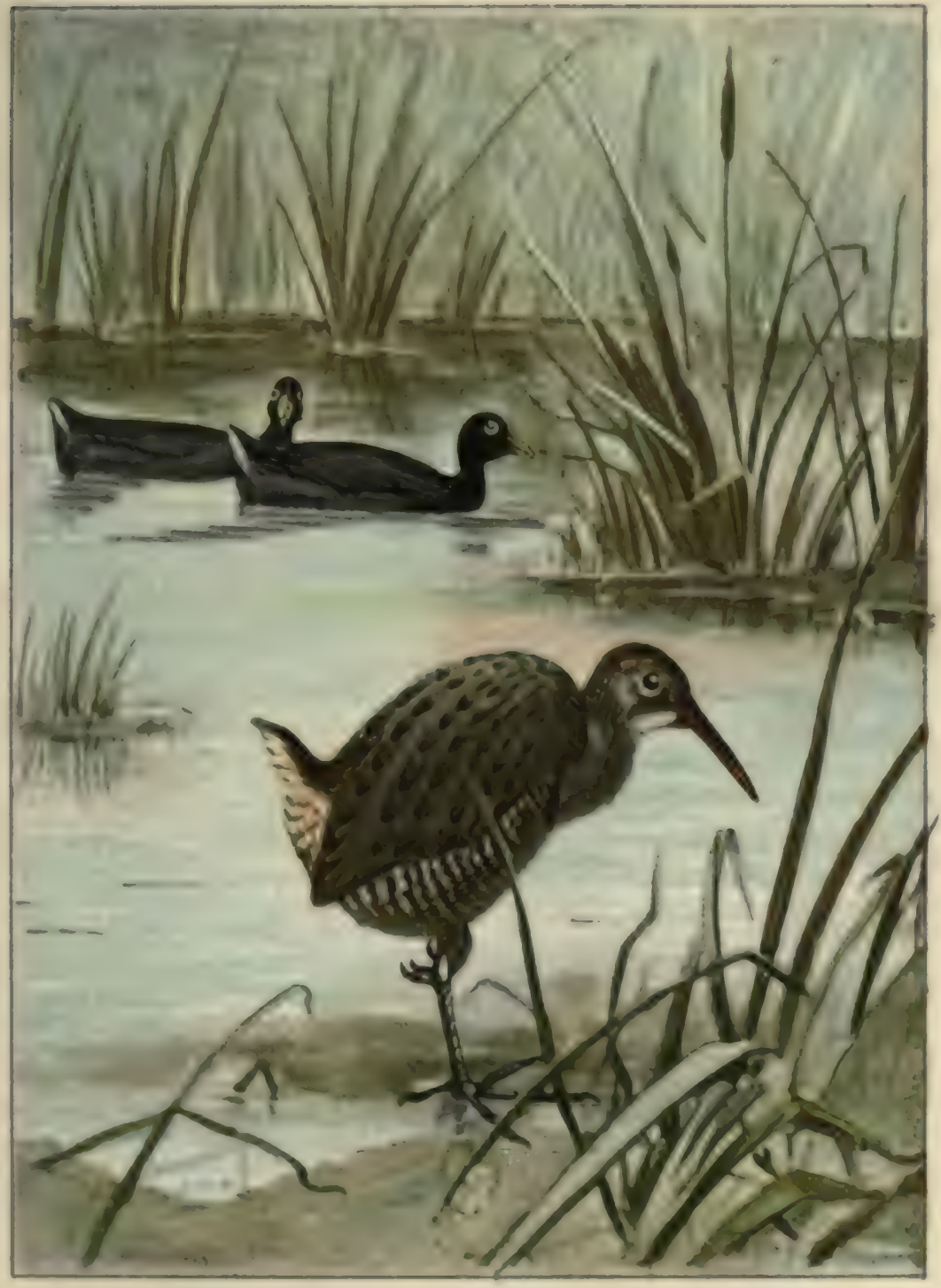

PLATE VIII.

\section{AMERICAN COOT.}

Paan 9.

Length, 15-00 Inches. Head and neok blackish, body alate; under tall coverts, tips of secondartes, and end of blll white.

CLAPPER RAIL.

-Length, 14.50 inches. Upper parts pale greenish olive and gray; thruat white, breast palu cinnamon, flanks gray and white. 

outer feathers, as in the Meadowlark. The tail may also be expressive of disposition. Compare the drooped tail of a pensive Flycatcher with the uptilted member of an inquisitive Wren.

But it is when displaying its beauties that a bird speaks most eloquently with its tail. Can anything exreed the pormpons pride of a Turkey cock strutting in swollen glory, with tail stiftly spread? The Peacock erects his tail in a similar manner, but it is entirely concealed by the train of gorgeous feathers which it par. tially supports.

The Feet.-As the feet share with the wings the responsibilities of lucomotion, there is often a close relation between these organs. For example, short-winged terrestrial species like Quails, Grouse, and Rails have welldeveloped feet, but such aërial creatures as Swifts and Swallows have exceedingly small feet (see Figs. 3 and 4). The aquatic Grebes and Divers are practically helpless on land, but the Ostrich can outrun the horse; while in the perching birds the foot is so specialized that by the auto-

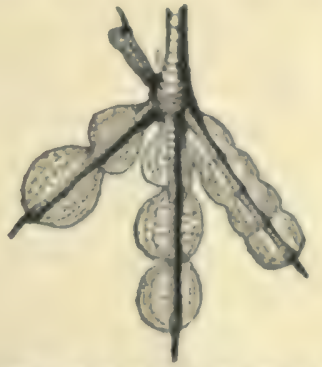

Fio. 13.-Inhed font of a Cout, a swimming bind of the Ituil family. ( $1 /$ s natural size.)

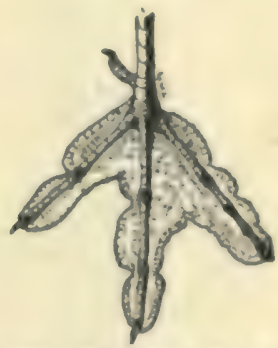

Fta. 18. - Lobed font of a Pbularope, aswimming lind of the Suipe farnily. (Natural size.)

matic action of certain tendons the birds are locked to their perches while sleeping. $A$ webled font implies ability to swim, and we find this character present in all the 
water-loving Divers, Auks, Gulls, Cormorants, and Ducks. In the wading Iferons and marsh-inhabiting Rails and G.allinules the web is absent, but it reappears in the form of lobes on the toes of the aquatic Coots of the same family.

Some shore-inhabiting Snipe have the bases of the toes unitel by webs, but the Phalaropes, of two species, have lobed toes not unlike those of the Coots, and are true swimming Snipe living on the sea for long periods.

Length of foot is largely dependent upon length of neck. This is illustrated by the Herons, and is particu-

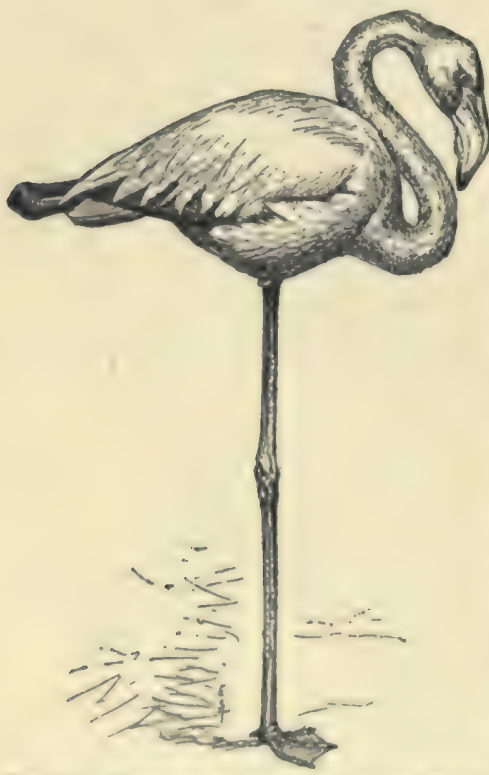

Fio.14.-Flaningo, showing relative length of leuss nnil neck in a wading bird. (Much reduced.)

larly well shown by the long-necked Flamingo, which has a foot twelve inches long. Its toes are webbed, and it can wade in deep water and search for food on the bottom by immersing its long neck and its head.

In the tropical Jacanas the toes and toenails are much lengthened, enabling the bird to pass over the water on aquatic plants. I have seen these birds walking on small lily leaves, which sank beneath their weight, giving one the impression that they were walking on the water (see Fig. 10).

Many ground-feeding lirds use the feet in scratching for food; Chickens are familiar examples. Towhees and 
Sparrows use both feet in searching for food, jumping quickly backward and throwing the lesves behind them.

Parrots use their foot as a hand. Some Hawks carry nesting material in it, and all lirds of prey strike their quarry with their strongly curved claws, which are then used to carry, or hold it while it is being torn by the bill. The foot of the Fish Hawk is a magnificent organ. The nails are strong and well curved; the inner surface of the toes is set with sharp, horny spikes, and the outer toe is partly reversible, so that the bird grasps its slippery prey from four different points.

As a weapon the foot is especially effective, the use of spurs being too

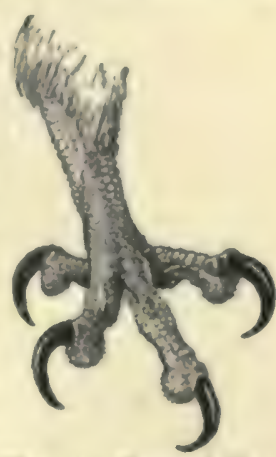

Fig, 15,-Font of Fish Hawk, whowing lange elaws, and spicules on uniler surfare of toes. $(1 /$, nutural size.) well known to require comment. $\mathrm{O}_{3}-$ triches kick with their feet, and can, it is said, deliver a blow powerful enough to fell a man.

But by far the best instance of modification in the structure of the feet is furnished by Grouse. It is an
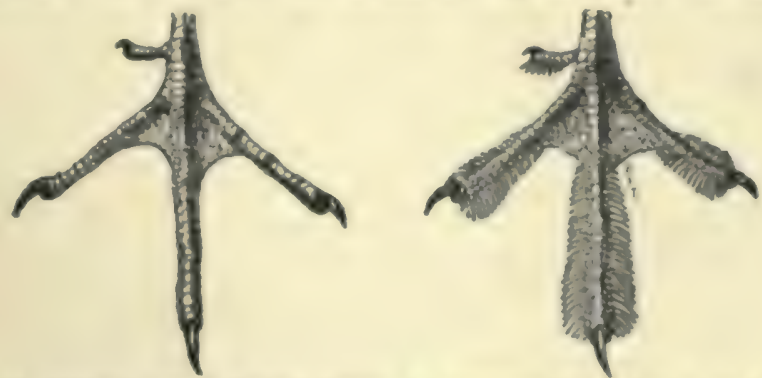

Fia. 38.- liaked toem of Rufferl (irouse in summer; finged toes of Ruffed Grouse in winter. (\% natuml aize)

unusual case of seasonal adaptation in form. During the summer the toes of Grouse are bare and slender, but as 
these birds are largely ground-haunters, and most of them inhabit regions where the snowfall is heary, the toes in winter acquire a comblike fringe on either side. Practically, therefore, Grouse don snowshoes in the fall, and wear them until the following spring.

The Bill.-Of the four organs we are considering, the bill is beyond question the most important. We have seen that a bird may be wingless and practically tailless, and may almost lose the use of its feet; but from the moment the bill breaks the eggshell and liberates the chick, the bird's life is dependent upon its services. The variety of offices performed by the bill, and the correspondingly numerous forms it assumes, are, doubtless, without parallel in the animal world.

The special modification of the fore limbs as flightorgans deprives birds of their use for other important services, and consequently we have a biped which, so far as their assistance goes, is without arms or hands. As a result, the duties which would naturally fall to these members are performed by the bill, whose chief office, therefore, is that of a hand.

Occasionally it is sexually adorned, as in the Puffins, several Auks, Ducks, and the White Pelicans, which, during the nesting season, have some special plate, knob, or color on the bill. With the Woodpeckers it is a musical instrument-the drumstick with which they beat a tattoo on some resounding limb. Owls and some other birds, when angry or frightened, snap their mandibles together like castanets. But it is as a hand that the bill gires best evidence of adaptation to or by halit. Among families in which the wings, tail, and feet are essentially alike in form, the bill may present great variation--proof apparently of its response to the demands made upon it.

All birds use it as a comb and brush with which to 


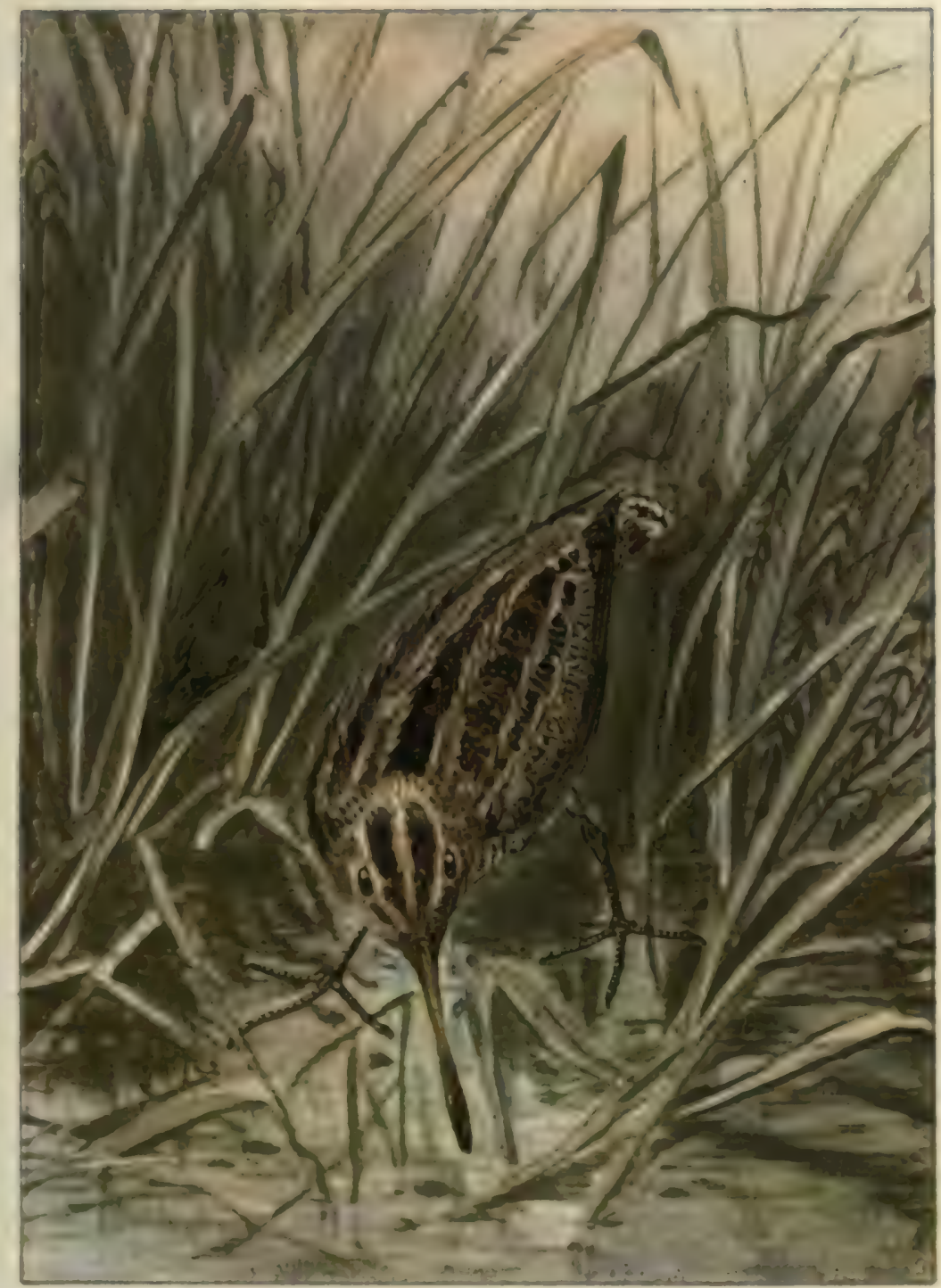

Prate IX.

PaAe 97.

WILSON'S BNIPR.

Length, 11.25 inchea. Opper parts black, buff and ruaty ; throat and belly white, rest of under parts black and buff. 

perform their twilet, and, pressing a drop of oil from the gland at the root of the tail, they dress their feathers with their bill. Parrots use the bill in climbing, and its hawklike shape in these birds is an unusual instance of similarity in structure accompanying different habits.

Birls which do not strike with their feet may use the bill as a weapon, but the manner in which it is employed corresponds so closely with the method by which a bird secures its food, that as a weapon the bill presen:s no special modifications. In constructing the nest the bill m.ty be used as a trowel, an auger, a needle, a chisel, and as several other tools.

But as a hand the bill's most important office is that of procuring food; and wonderful indeed are the forms it assumes to supply the appetites of birls who mяy recpuire a drop of nectar or a tiny insect from the heart of a Hower, a snake from the marshes, a clam or mussel from the ocean's beach, or a fish from its waters. The bill, therefore, becomes a forceps, lever, chisel, hook, hammer, awl, probe, spoon, spear, sieve, net, and knifein short, there is almost no limit to its shape and uses.

With IIumingbirds the shape of the bill is apparently related to the flowers from which the bird most frequently procures its food. It ranges in length from a quarter of an inch in the Small-billed Hummer ( Microrhynches) to five inches in the Siphon-bill (Docimustes), which has a bill longer than its body, and is said to feed from the long-tubed trumpet

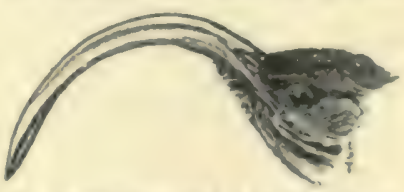

Fig. 1\%,-Decurved hill of Sinklebili Ilumminglired. (Natural size.)

flowers. The Avocet Hummer (Avocettula) has a bill curved slightly upward, but in the Sickle-billed Hummer (Eutoxeres) it is curved downward to form half a circle, and the bird feeds on flowers having a similarly curved 
corolla. In the Tooth-billed Hummer (Androdon) both mandibles are finely serrate at the end, the upper one being also hooked, and the birl feels on insects which it captures on the surface of leaves and other places.

Among the Woodhewers (Dendrocoluptidu) of South America there is fully as much variability, which reflects

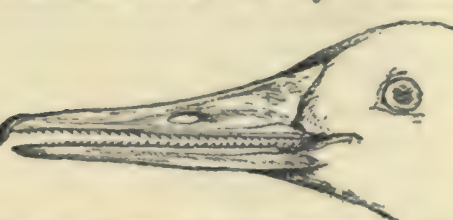

FIG. 18.- Serrate bill of Merganser, a fisheating bird. ( $1 / 2$ nutural size.)

equally variable feeding habits. Some species have short, stout, straight bills, others exceedingly long, slender, curved ones. Mergansers, Gannets, Anhingas, and other birds that eatch fish by pursuing them under water, have sharply serrate mandibles, which aid them in holding their slippery prey.

Some shore birds (Limicolox) use the bill as a probe,

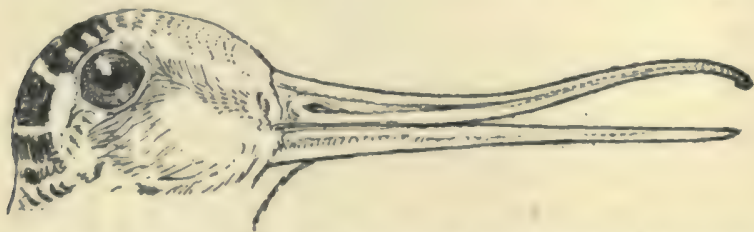

Fro. 19.-Probelike hill of Woorleock, showing extent to which upper mandible can be moved. ( $\%$, natural size.)

when it may be six inches in length and straight, of curved downward. It has recently been learned tliat

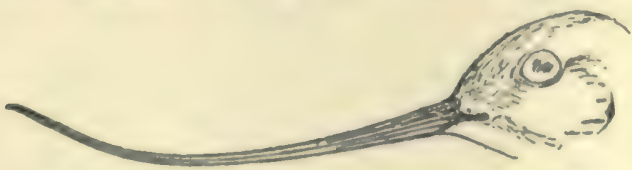

Fro. 20.-Recurved bill of Avocet. ( $\% / 2$ natural size.)

several of these probing Snipe, notably the Woodcock, have the power of moving the end of the upper mandi- 
ble, which letter enables them to grasp objects while probing. In the A rocet the till is curved upward, and tle bird swings it from side to side, scruping the lottom in its search for food. The New Zealand Wrybill has its bill turned to the right for the terminal third, and the bird uses it as a crooked probe to push under stones in hunting for its prey. The Siberian Spoonbill Sandpiper has a most singular

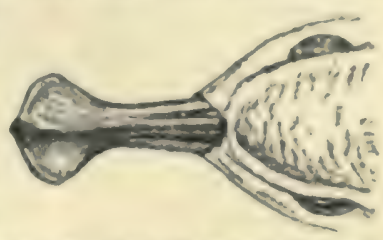

F10. 21.-Bill of Sponnbill Savdpiper. (Natural size.) bill, which is much enlarged at the end, suggesting a flat-ended forceps. The Roseate Spoonhill, an entirely different bird, has a somewhat similarly shaped bill, a striking instance of the occurrence of the same form in families which are not closely related.

But probably the most remarkable instance of relation

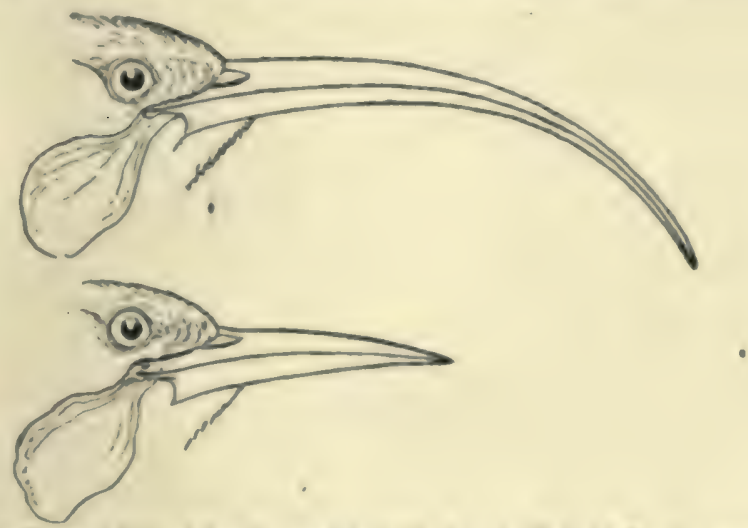

F10. 88.-Curvel bill of fenuale, straight bill of male Iluia-bird. ( $1 / 3$ natural size.)

between the form of the bill and feeling halits is furnished by the Huia-bird of New Zealand. The male of this species has a comparatively short, straight bill, while 
that of the female is long and curved. The birds feed on larræ, which they find in dead wood. The male hammers and chisels away the wood very much as Woodpeckers do, while the female uses her bill as a probe. We have, therefore, the singular case of two forms of the bill arising in the same species as a result of or caus. ing a corresponding difference in babit. 


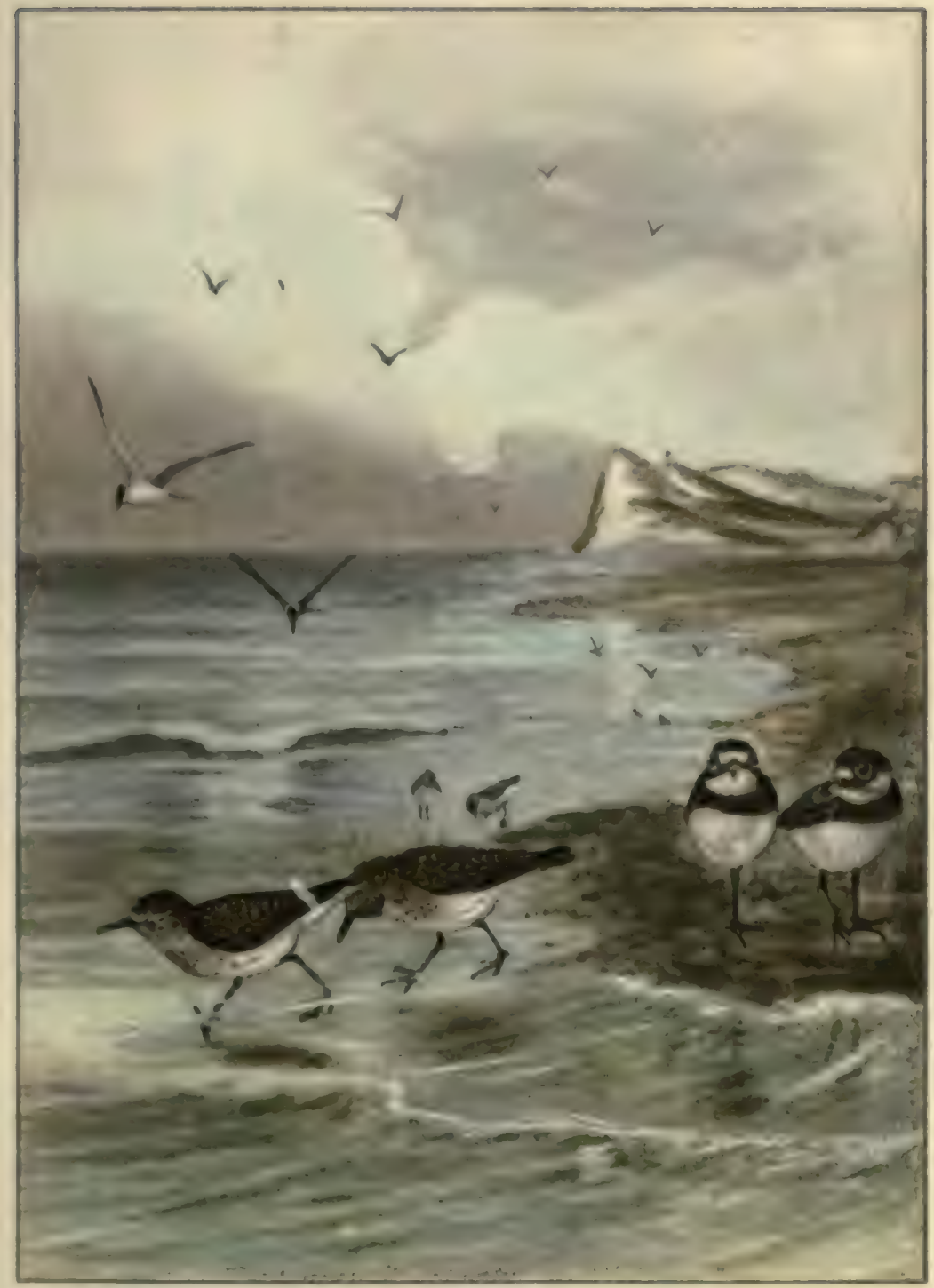

PLATK X.

PAons 87, 98, 99.

COMMON TERN.

(Length, 15.00 inches.)

SEMIPALMATED RANDPIPER. SEMIPALMATED PLOVER.

(Longth, 0.,0 inches.)

(Length, 0.75 inches.) 



\section{CHAPTER III.}

\section{COLORS OF BIRDS."}

THE almost endless range of variation in the colors and pattern of coloration of birds' plumage has attracted the attention of many philosophic naturalists. Why, for example, should birds from some regions always be darker than those from other regions; why should ground-inhabiting birds generally wear a dull or neutral tinted costume; and why should the male, with few exceptions, be brighter than the female?

For answer I will outline some of the leading facts and theories in connection with this interesting subject. In the first place, howerer, it will le necessary for us to have some idea of the extent of individual cliange in color, that is, the various phases of color, which a bird may pass through during different periods of its life. $\dagger$

- Consult Poulton, Colors of Animale (D. A ppleton \& Co.). Gadow, in Diewton's l)ietinnary of Birds-articles, Colnr and Feathers. Beddard. Animal Coloration (Macmillan (o.). Keeler. Erolution of the Colors of North American Iand Birds: occasional papers, California Academy of Sciences (San Francisen), iii. 1893. Alsn Allen, reviews of last two works. The Ank (New York cily), x, 1893. pp. 189-199. 373-380. Allen, Allegerl Changes of Colne in the Feathers of Birls without Inling: Bulletin of the American Museum of Natural History. Sew York city. viii, 1896. Pp. 13-44. Chmithourne, Indiviulual Dichromatism in the Screech Owl; Tho Auk, xiii, 1808, pp. 321-325. and xiv, 1887, Pp. 83-39, one plate.

† The term color, as here usel, means practically the plumage or dreos of birds. 
Color and Age.-All birds have a special nestling plumage. With those that run or swim at birth, such as Grouse, Snipe, and Ducks, this is a full suit of down, which may be worn for several weeks. With those birds which are helpless when hatched-for instance, Robins, Sparrows, and Orioles - this downy covering is so seanty that they are practically naked. This birth dress is followed by a new growth, known as the "first plumage." Down-covered birds do not acquire this for some time, but with those birds that are born nearly naked it begins to grow soon after they are hatched, and is almost complete when they leave the nest. The first plumage is often unlike that of either parent; for example, the spotted plumage of the Robin. It is worn for several months by some species - certain Snipe and others -but with most land birds it is soon exchanged for the costume they will wear through the winter, usually termed the "immature plumage." This may resemble that of either parent respectively-that is, immature males may be like adult males and immature females like adult females, as with the Bob-white and Cardinal Grosbeak; or the immature birds of both sexes may resemble the adult female, as with the Hummingbird and Bobolink. Again, the immature birds of both sexes may be unlike either of the adults, as with the Eagle end most Hawks; or the immature female may resemble the adult female, while the inmature roale is unlike cither parent, as in the case of the Rose-breasted Grosheak and Scarlet Tanager. When both parents are alike, the young generally resemble them, and this happens among most of our land birds; for example, the Flyeatchers, Crows and Jays, many Sparrows, Vireos, 'Wrens, and Thruslies.

Immature birds, differing from the adults, may acquire the adult plumage the next spring. as with the Bobolink, or they may then don a second or transition 
plumage, and not assume the dress of maturity until the second or even the third spring, which is the case with the Orehard Oriole.

Collor and seusom.-Quite apart from the changes in color due to age, a bird may throughout its life change costumes with the sensons. Thus, the male Bobolink after the nesting season, exchanges his black, white, and buff nuptial suit for a sparrowlike dress resembling that of his mate. The Scarlet Tanager sheds his gay body plumage and puts on the olive-green colors of the female, without ehanging, however, the color of his black wings and tail. The following spring both birds resume the more conspicuous coats. A more or less similar change takes place among many birds in which the male is brighter than the female, but, among land birds, when the adults of both sexes are alike, there is little or no seasonal change in color.

The Molt.* - These changes in plumage, as far as they are understood, are accomplisheil liy the molt, frequently followed by a we.ring off of the differently colored terminal fringe which is found on the new feathers of some birds. It has been stated that lirds change color without changing their plumage, either by a chemical alteration in the gigment of the feathers resulting in a new color, or lyy the actual gain of new pignent from the body; but I know of no instance in which this has been proved, nor Io I leelieve that the latter change is possible. The whole sulject offers an excellent field for olservation and experiment.

There is a great and as yet but little understond variation in the molting of birds. Not only may closely

- See Stune. The Multing of IBirils, with Speciul Reference to the Plamazes of the Simaller lanul Birils of Viastern Nurth Aneriea, Proceredings of the Philzolefphia Acadeny of Dacural Science, 1846, PH 108-167, two plates. 
related species molt differently, but the manner and time of molting among individuals of the same species may vary according to their sex, age, and physical condition.

At the close of the nesting season all birds renew their entire plumage by molting. The following spring, before the nesting season, most birds molt their body feathers, retaining those of the wing and tail. A few, however, like the Bobolink, have a complete molt at this season also. Others molt only a few of the body feathers, while some birds are adorned at this season with special nuptial plumes.

The beautiful aigrette piumes of the Heron constitute a nuptial dress ot this kind. It is for these plumes that the birds have been slaughtered in such enormous numbers that if the demand continues they will speedily become extinct.

Some birds, whose fall plumage is edged with a differently colored tip to each feather, do not molt in the spring, but acquire their wedding dress by the slow wearing off of the fringes to the feathers which have dis-

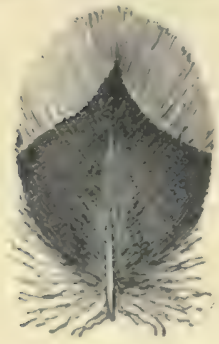

October.

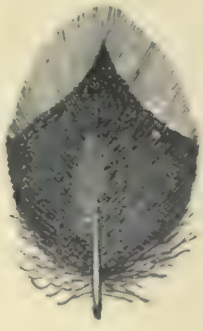

January.

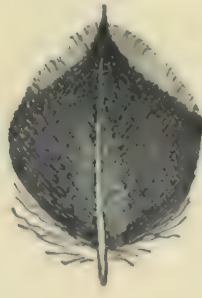

March.

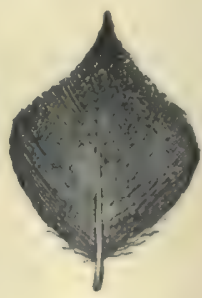

June.

Fic. 23.-Feathers from hack of Snowflake, showing seasonal changes in form and color due to wearing off of tips. (Natural size)

guised them during the winter. The Snowflake, for instance, changes from brown and brownish white to pure black and white by losing the brown tips which have concealed the black or white bases of his feathers. 


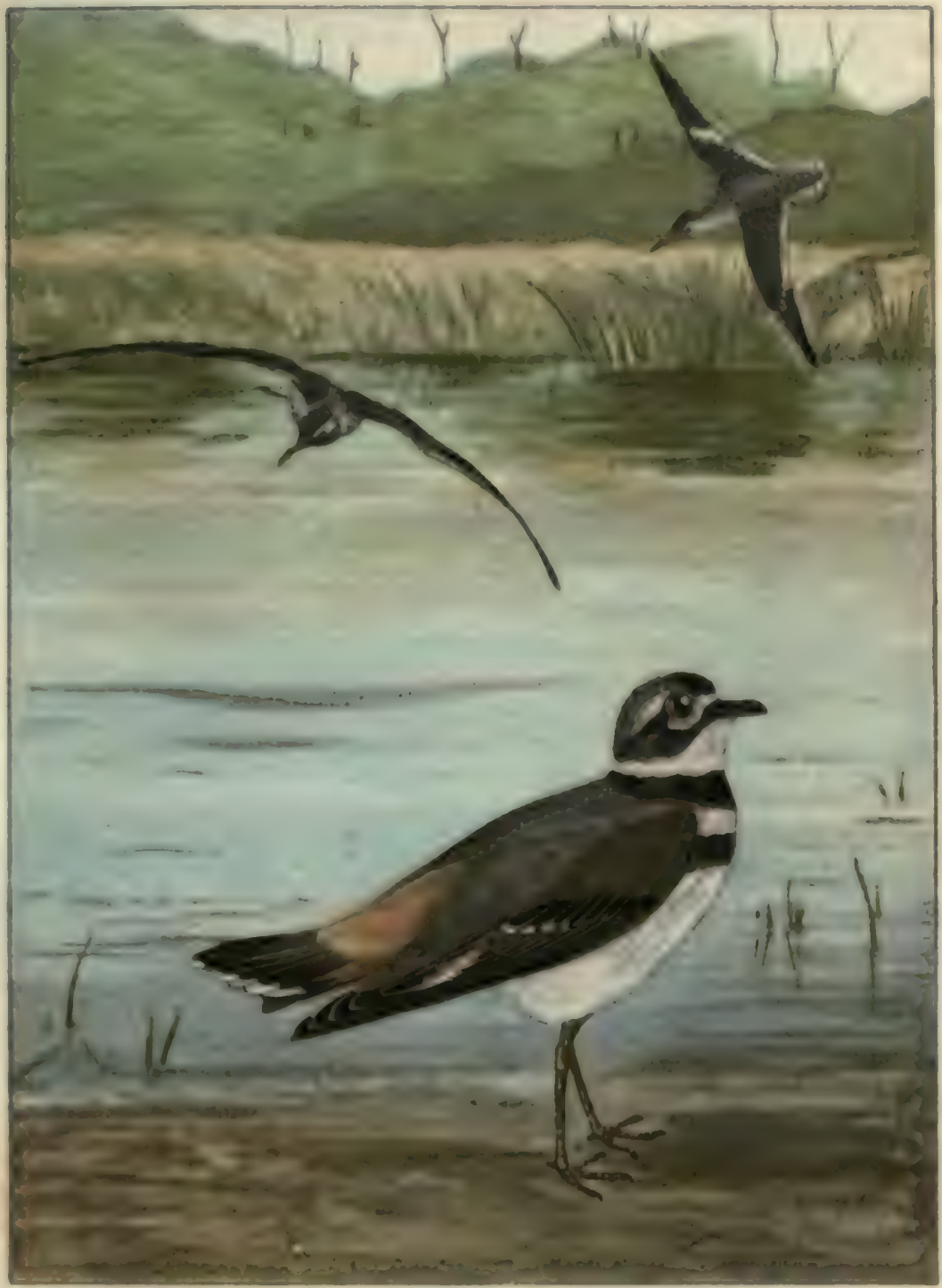

Plate XI.

\section{POTTED 8ANDPIPER.}

PAare 96, 99.

Length, 7.50 Inches Adult, upper parts brownieh gray and hlack; under parts white spotted with black: a white patch in wing. Young, similar, but without black.

\section{KILLDEER.}

Length, 10-50 inches. Tpper parts brownisb gray, upper tall-coverts rusty: under parts white: two bands on breast, crown and lores black, forehead and nape white. 

Much remains to be learned on this subject of the molt, and, although confinement is known to affect its manner and extent, I believe intelligent olservation of eaged birds will lead to really valuable results.

Color and Froml.- In some instances it is known that a bird's color is affected by the nature of its food. It is a common practice among bird fanciers to alter the color of Canaries from yellow to orange-red by feeling them on red pepper. This food, however, is said to have no effect upon adult birds, but must be fed to nestlings. Sauermann's experiments, as quoted by Beldard, show that the red color is not eansed by the capsicin or red pigment in the pepper, but by a fatty sulstance termed triolein. Fed to white fowls, their breasts hecame red, while the rest of the plumage remained unchanged. It is also stated that dealers alter the color of green Parrots to yellow by feeding them on the fat of certain fishes.

Flamingoes and Scarlet Ibises when kept in captivity lose their bright red eolors and become dingy pink or even soiled white, and some animal dealers have acquired a reputation for restoring their natural tints by supplying them with food the nature of which is kept a secret.

Our Purple Finch turns to yellow in eaptivity. An adult male now in my possession is undergoing his second molt since capture a year ago, and it will evidently leave him without a single red feather. Other wild birds when caged are known to assume more or less abnormal plumages, due, it is supposed, to change in food. There is, however, very little exact information on this subject, and it offers an excellent opportunity for the patient in. vestigator.

Colm and Climate. -Color is a much more variable character than form. There are but few instances in

- Read Allen. Bulletin of Museum of Compurative Zoülogy (Cam. bridge, Nass), vol. ii. No. 3, 1871, pp. 18n-250. 
which we can show the cause of a given structure; but color responds more quickly to the influence of surroundings, and in many cases we can point to cause and effect with some certainty.

This is best illustrated by the relation between climate and color. Briefly, it has been found that birds are darkest in humid regions and palest in arid regions.

This at first thought seems of small moment, but in reality it is one of the most important facts established by ornithologists. It is an undeniable demonstration of "evolution by environment" - that is, the bird's color is in part due to the conditions under which it lives.

For example, our common Song Sparrow, which inhabits the greater part of North America, varies so greatly in color in different parts of its range that no less than eleven subspecies or geographical races are known to ornithologists. The extremes are found in the arid deserts of Arizona, where the annual rainfall averages eight inches, and on the humid Pacific coast from Washington to Alaska, where the annual rainfall averages about eighty inches.

The Arizona Song Sparrows are pale, sandy colored birds, while those from Alaska are dark, sooty brown. One would imagine them to be different species; but unlike as are these extremes, they, with the other nine races in this group, are found to intergrade in those regions where the climatic conditions themselres undergo a change. That is, as we pass from an arid into a humid region, the birds gradually get darker as the average rainfall increases.

If now we study other birds living in these regions, we find that many of them, especially the resident species, are similarly affected by the prevailing climatic influences-that is, many Arizona birds are bleached and raded in appearance, while all the thirty odd Northwest 
Pacific const races are darker or more heavily streaked or barred than any of their congeners. It is of importance to ohserve that these differences are khown by young hirds in fresh plumage-evidence that the charac. ters acquired through climate have been inherited.

There are many similar cases, but some species seem more easily affectel than others, and thronghesut their ranges are marke.lly affecte.l $\mathrm{ly}$ the conditions under which they live. Thus we have nine raves of Sereech Owl, eleven of Ilorned Lark, six of Junco, ete.

These races, or sulneperies, are species in process of formation. The extremes are still connected hy intermediate or natural links, but if, through any cause, these intermeliates should disappear, the extremes would then be left as distinct species.

Color and IIaunt and Ilulit.-The relation of a tiril's color to its haunts and labits is a complex sul,jeet. Any attempt at its explunation should be based on so exact a knowledge of the fucts in the case, that I can not too strongly emphasize here the necessity for observations in the field. Only a close study of the living bird will justify us in advaneing theories to account for its coloration.

Many explanations have been offered to aceount for certain colors and markings of birds, but often, I fear, without adequate knowledge of the bird's habits. I shall spesk of only four classes of colors; they are motective, deceptive, recompition, and sexual colors.

Protective colons render a lird ineonspicuous in orler that it may escape its enemies. Deceptive colors render it inconspicuous in order that it may more ensily approach its prey. In both eases the bird should harmonize in color with its immeliate surroundings.

A snrvey of the lirds of the wurld shows that on the whole this is true. Thus almost all ground-intubiting birds, such as Snipe, Plover, Quail, Grouse, Sparrows, 
are generally dull brown or gray, like the ground, leaves, or grasses about them, while tree-haunting birds, especially those that live in the folinge or feed from blossoms, are, as a rule, brightly colored. In this class belong Hummingbirds, Orioles, the gayer-plumaged Finches, Tanagers, Warblers, and many others. It is partly owing to this fact that the erroneous idea concerning the brilliant plumage of all tropical birds has become established. The rich vegetation of the tropics furnishes a home to a far greater number of brightly colored birds than are found in temperate regions: still, they are not more numerous than the dull-colored species that live on the tree trunks, in the undergrowth, or on the ground, where, owing to the nature of both their colors and haunts, they are likely to be overlooked.

Between these two extremes there are numerous intermediate groups, most of which conform to the general law of protective coloration. There are, it is true, exceptions, but every close student of bird-life must be so impressed with the dangers to which birds are exposed, that he can not doubt that the chief object of color is usually for its wearer's concealment.

The term "protective coloration" has lately received fresh significance through the studies of Mr. Abbott $\mathrm{H}$. Thayer.* Mr. Thayer proves conclusively that protective coloration lies not so much in an animal's resemHance in color to its surroundings as in its gradation of color. Thus he points to the fact that, as a rule, animals are darker above than below - that is, those parts receiving the most light are darkest, while the parts receiving the least light are palest. In effect it follows that the darker upper parts are brightened, while the paler under parts are

- See his papers 'on The Law which Underlies Protective Coloration, in The Auk (New York city), vol. xiii, pp. 124-129, 318-320, eleven figures. 


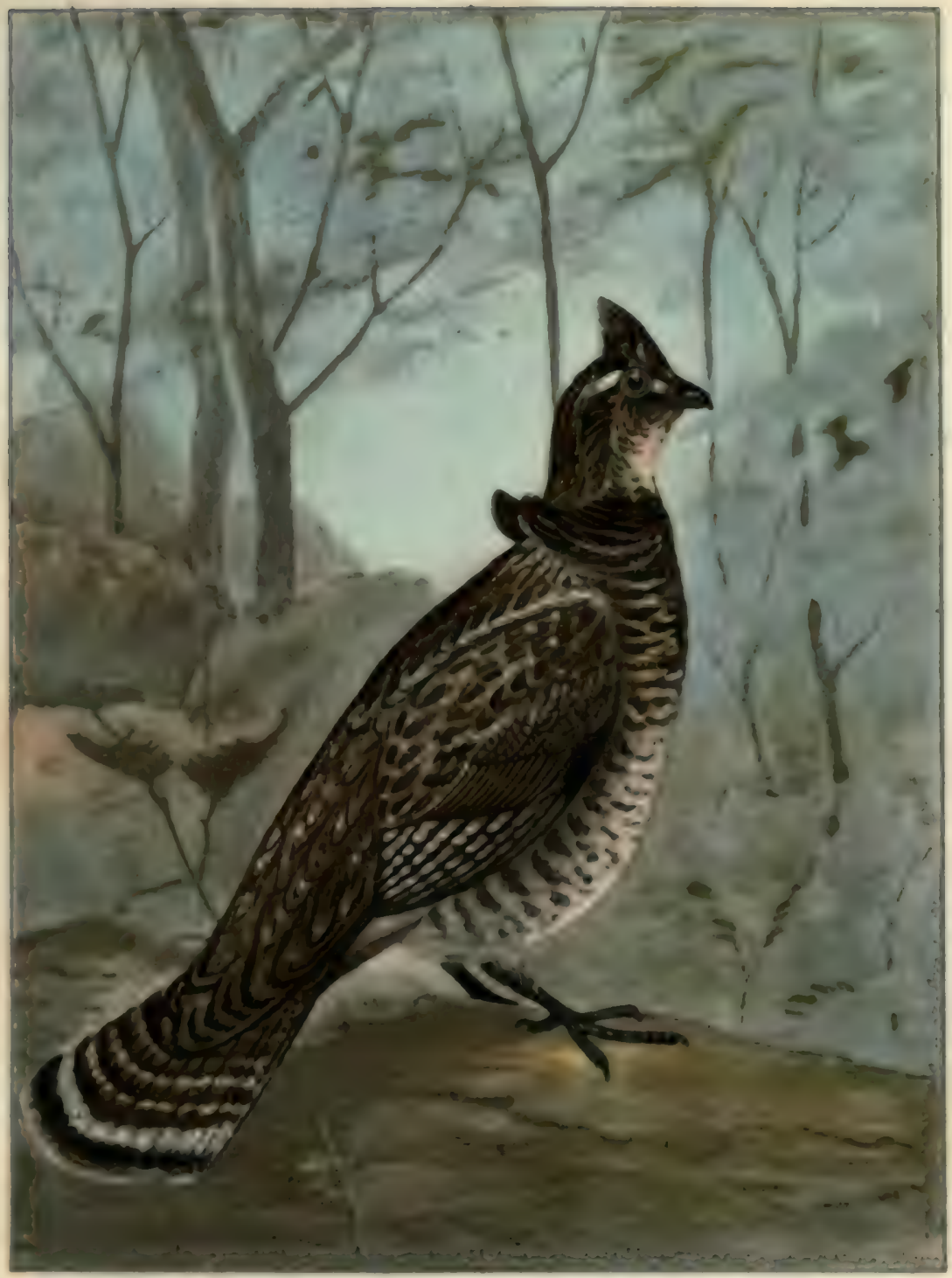

Putre XII.

\section{RUFFED GROU8E.}

Page 10t.

Length, 17.00 inches. Male, neok tufts long, black; upper parts and tall gray or rusty, black and bua; under parts white, black and rusty. Female, similar, but with neok tufts no longer than adjoining feathers. 

darkened, the result being a uniform color, witb an apparent absence of shadow, tending to render the object invisible.

Mr. Thayer clearly demonstrates his discovery by using several decoys about the size and shape of a Woodcock's body. These he places about six inches above the ground on wire uprights, or in a row on a horizontal rod. One of these decoys he colors uniformly, above and below, to resemble the earth about it, or he may even give it a fine coating of the earth itself. The upper half of the other decoys is treated in exactly the same manner, but their lower half is graded to a pure white on the median line below. At a distance of forty or fifty yards the uniformly colored decoy can be plainly seen, but those which are white below are entirely invisible until one is within twenty or thirty feet of them.

After definitely locating these graded decoys the ex. periment muy be repeated; but the result will always be the same. As one slowly retreats from them they will, as hy mugic, scem to pass out of existence, while the one which is colored alike both above and below can be seen distinctly.

One of the best arguments for the value of a protective coloration is the fact that the birds themselves are such thorough believers in it. Here we have the reason why - in sportsman's parlance-game birds "lie to a dog." When there is sufficient cover, they trust to their protective coloring to escape detection, and take wing only as a last resort; but when cover is scanty, they generally rise far out of gunshot. Some Snipe and Sparrows, however, attempt to conceal themselves even on bare sand or worn grass by squatting close to the earth, with which their plumage larmonizes in color.

A sitting Woodcock had such confidence in its own invisibility that it permitted itself to be stroked without leaving the nest; but when a light snow fell, and the 
bird became a conspicuous dark object against a white background, it took wing on the first suspicion of danger.

I could mention many other similar instances, but the careful observer will soon find them included in his own experience.

Deceptive, or, as Poulton terms it, "aggressive" col. oration is perhaps best illustrated by common Flycatchers (Tyrannidas). Although these birds live in and about trees, they are, as a rule, quietly attired in olive-green or olive-gray, and are quite unlike the brilliantly clad, fruiteating Tanagers, Orioles, Parrots, and other birds that may be found near them. Insects are therefore more likely to come within snapping distance than if these birds were conspicuously colored. In the same manner we may explain the colors of Hawks, which are never brightly plumaged.

It is well known that many aretic animals become white on the approach of winter. With Ptarmigans this is doubtless an instance of protective coloration, but the Snowy Owl, who feeds on the Ptarmigan, may be said to illustrate deceptive coloration.

Recognition, signaling, or directive colors have, with more or less reason, been made to include many different types of markings, of which I shall mention only those that are conspicuonsly shown in flight or by some movement. Such are the white outer tail-feathers of Juncos, Meadowlarks, Towhees, and many other birds, and certain wing and rump patches, which are noticeable only when the bird is on the wing. Markings of this kind are supposed to aid birds in recognizing others of their kind, their special use being to keep the individuals of a family or flock together, so that when one starts the others can readily follow. The theory is open to objections, but these so-called recognition marks are so often found among birds that they doubtless are of some use, though their 
exact value remaius to be determined by closer observation.

Color and Sist."-It is not possible here to discuss at length the rexed question of sexual coloration. But, as a means of directing observation, I present a synopsis of the principal types of secondary sexual characters, with some of the theories which have been advanced to acrount for them.

SYNUISIS OF TIE SECONDARY SEXLAI, CHARACTERS UF BIRDS.

\section{BTRUCTURAL}

Size. $\{$ Male larger than female (usual).

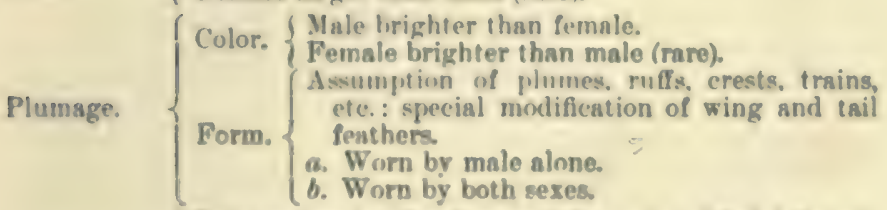
(1) the body. $\left\{\begin{array}{l}\text { Sole or greater development in male of brightly col- } \\ \text { ored lure tracts of skin, combs, wattles, caruncles. } \\ \text { and other fleshy or horny appendages. }\end{array}\right.$ Of the feet. Sile or grenter development in male of spurs.

Of tho bill. $\left\{\begin{array}{c}\text { Male with more highly colored or larger bill than } \\ \text { female. }\end{array}\right.$

\section{TUNCTIONAI.}

Pursuit. $\quad$ I $\mathrm{Br}$ male when similar to or brighter than female.

Display. $\quad$ By male of ncessory plumes and other appendagea.

Battle. By male using spurs, wings. bill, etc.

Mavic. $\quad\left\{\begin{array}{l}\text { Vocal, by male and, rarely, female. } \\ \text { Mechanical, by mule and sometimes female. }\end{array}\right.$

Dances, mock fights, aïrial evolutinns, construction of

Siperial bowers, decoration of playgrounls, attitudinizing.

habite.

strutling. etc.

a. By male hefore the female.

b. Among the males alone.

- Read Darwin. The Descent of Man and Selection in Relation to Sex (D. Appleton \& Co.). Wallnce, Darwinism (Macmillan Co.). 
In explanation of these remarkable differences of form and habit, we have first Darwin's theory of "sexual selection." This is based upon the ardor in love, the courage and rivalry of the males, and also upon the powers of perception, taste, and will of the female.

The spurs of the male, for example, are supposed to have been developed through the battles of the males. At first a mere knob, they were an advantage to the bird possessing them, enabling him to defeat his rivals. The successful male would be more likely to have offspring who would inherit the tendency of their father to have spurs, and thus, by selection, the unspurred cocks would gradually be replaced by those better armed. This is known as the "law of battle."

But the bright colors and gay plumes of the cock have originated, under this theory, through the taste of the female, who, it is assumed, would be more likely to accept the attentions of a bird pleasing in her eye than one who was less strikingly adorned. This has been termed by Lloyd Morgan "preferential mating."

Wallace has accepted the law of battle as an effective agent in producing certain characters, but considers it natural, rather than sexual selection, and he denies the existence of any important evidence proving female selection. He therefore attributes many secondary sexual characters to a surplus of vital energy, which, because of a bird's perfect adaptation to the conditions of its existence, can expend itself in the production of bright colors and ornamental plumes without injury to their owners. That is to say, Wallace ascribes to the action of natural selection any secondary sexual character which is of practical use to the male in conflicts with a rival, but denies the fernale any part in the matter of pairing. Darwin, as I have said, attributes to the female an rsthetic taste which renders the brilliant colors or display of the 


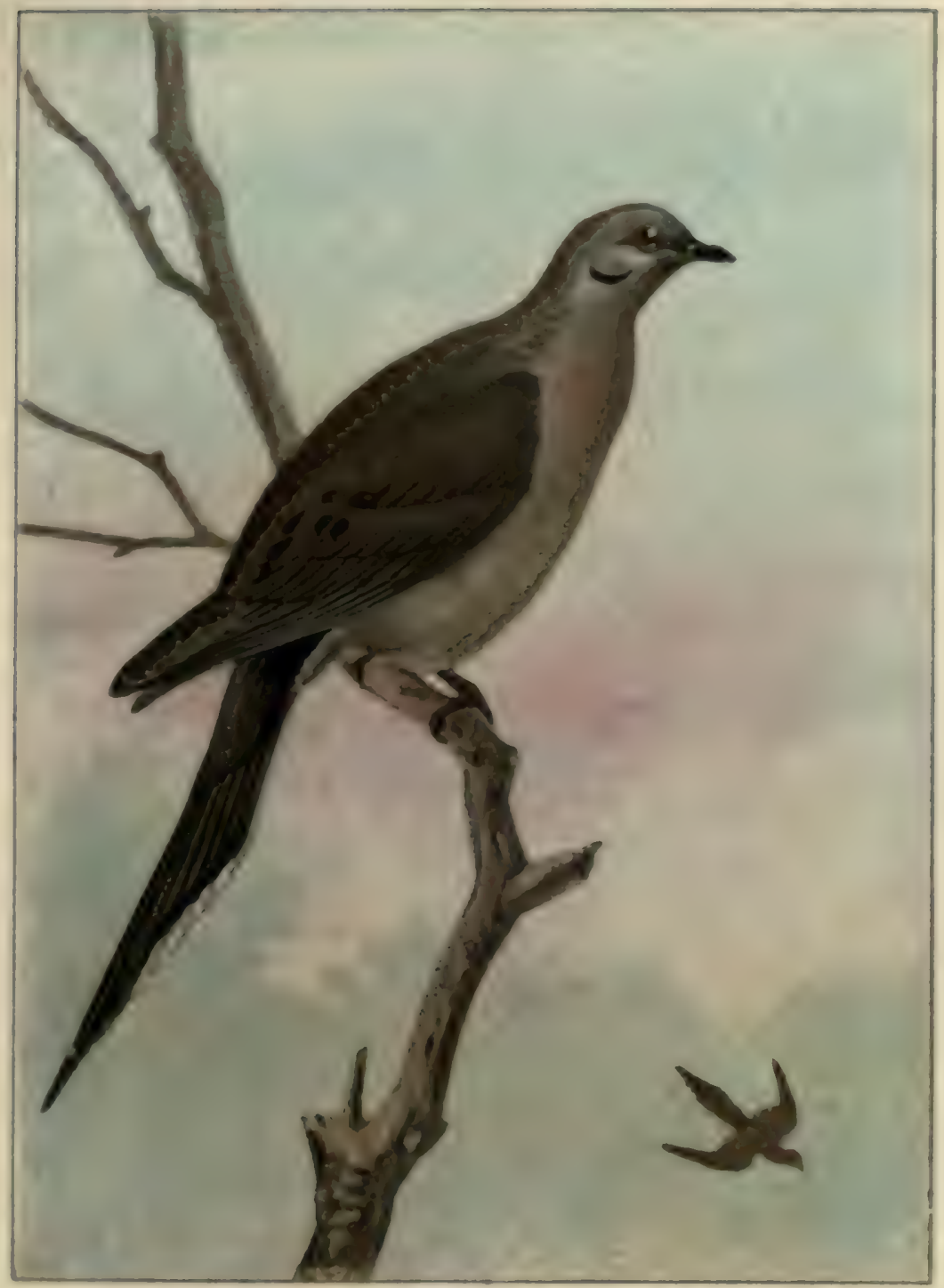

PLate XIII.

\section{MOERNING DOVE.}

PAan 102.

Length, 11.75 Inchea. Upper parts ollve graylsh brown, sides and back of neck Iridescent; breast with a plnkish tinge, belly buff; outer tailfeathers tipped with white. 

male an attractive sight, influenciug her choice of a mate.

There is thus a practical agreement in the views of these naturalists on the origin of those sexual charactens which may be classed as wenpons, and this opinion is, I believe, generally accepted. But the question of female preference, and its influence on the develupment of bright colurs and accessory piumes, still lacks confirmation. Here is an opportunity for every one who can watch wild birds mating. 


\section{CHAPTER IV.}

\section{THE MIGRATION OF BIRDS.*}

To the field student the season of migration is the most interesting of the year. The bird-life of a vast area then passes in review before him. Though living in a temperate region, he may see birds whose summer home is within the Arctic Circle, whose winter haunts are in the tropics. Who can tell what bird he may find in the woods he has been exploring for years?

The comparative regularity with which birds come and go gives an added charm to the study of migration. Their journey is not a "helter-skelter" rusling onward, but is like the well-gorerned march of an army. We feel a sense of satisfaction in knowing when we may expect to greet a giren species, and a secret elation if we succeed in detecting it several days in advance of other observers. We study weather charts, and try to foretell or explain those great flights or "wares" of birds which are so closely dependent upon meteorologie conditions.

* Read Allen, Seribmer's Magrazine, vol. xxii, 1881, pp. 9:32-938. Bulletin of Nuttall Ornithological Club (Cambridge. Mass.), vol. v, 1880, pp. 151-154. Scentt. ibill. rol. vi, 18,0. pp. 9i-100. Brewster. Memoirs of Nuttall Ornitholngieal Cluh, No. 1, pp. 22. Conke and Merriam. Bird Migration in the Mississippi Valley (Washington. 1888). Chapman, The Auk (New York city), vol, v. 1888, pp. 37-39; vol. xi, 1894, pp. 12-17. Lnomis, ibirl.. vol. ix. 1892. pp. 28-39: vol. xi, 1894, pp. 26-39. 94-11\%. Stone, Birds of Fastern Pennsylvania and New Jersey, pp. 15-28. 
Estent of Migrution.-The extent of a bird's migmtion is, in most cases, deprendent upon the mature of its fond. Birde that are resident in one place thronghest the year generally change their fare with the season, and apparently feeed with equal relinh on meeds or insects. These that are deprendent upon fruit must migrate far enongh to find a supply of terries, while the insect-eaters are obligeal to travel even farther south.

Most of the migratory birls of our Western States pass the winter in Mexien. Our Eastern Sparrows and our herry-eaters, like the Rolin and Bluebirl, winter from the Middle States to the Gulf coast, while the majority of our purely insectivorous species cross to Cuhs and winter in the West Indies, or continue to Central Ameriea and even northern South America. Snipe and P'loser make the most extended migrationa, some species breeding within the Aretic Circle and wintering alung the coasts of Patagonia.

Times of Migrution.-Let us suppose we are abrut tw observe the spring migration of birds at Englewood, New Jersey-a few miles from New York eity. Birds arrive here ahout a week later than at $\mathrm{W}$ ashington, D. C., and a week earlier than at Buston.

During January and February, while watching for some nure visitor from the North, we shall find that Tree Sparrows and Juneos are everywhere common. Less frequently we may see Shrikes, Winter Wrens, Goldencrowned Kinglets and Brown Creepern, and marely Snowflakes, Re.l Crosstills, and Redpolls will he otserved. These birls are winter visitants, coming to us from the North in the fall and leaving in March and April.

Of course, in adlition to these migratory birds, we shall sce most if not all of our commoner permanent resilents, or the birds which are with us throughout the year. They are the Bob-white, Ruffed Grouse, Red- 
shouldered and Red-tailed Hawks, Barred and Screech Owls, Downy and Hairy Woodpeckers, Blue Jay, Crow, Goldfinch, Song Sparrow, White-breasted Nuthatch, and Chickadee.

Generally speaking, the birds in the front rank of the feathered army which soon will invade the land are those whose winter quarters are farthest north, while those that winter farthest south bring up the rear.

From February 20 to March 10, therefore, we may expect to see Purple Grackles, Robins, Bluebirds, and Red-winged Blackbirds; birds that have wintered but a short distance south of us-if not with us-and who have accepted the slightest encouragement from the weather as an order to advance. All the first comers will doubtless be males, this sex, as a rule, preceding the females by several days.

About the middle of March we may look for the Woodeock, Meadowlark, Fox Sparrow, Cowbird, and Phœbe; their time of arrival being largely dependent upon the temperature-warm weather hastening, and cold weather retarding their movements.

Toward the last of March, Wilson's Snipe, the Kingfisher, Mourning Dove, Swamp and Field Sparrows are due.

Early in April the Purple Finch, White-throated, Vesper, and Chipping Sparrows will announce their return in familiar notes, and at the same time Tree Swallows, Myrtle Warblers, Pipits, and Hermit Thrushes will appear. They will soon be followed by Barn Swallows and Ruby-crowned Kinglets.

The migration is now well under way, and we go to the field with the assurance of meeting some lately arrived feathered friend almost daily. Between April 20 and 30 we will doubtless note among the newcomers, the Green Heron, Spotted Sandpiper, Whip-poor-will, 


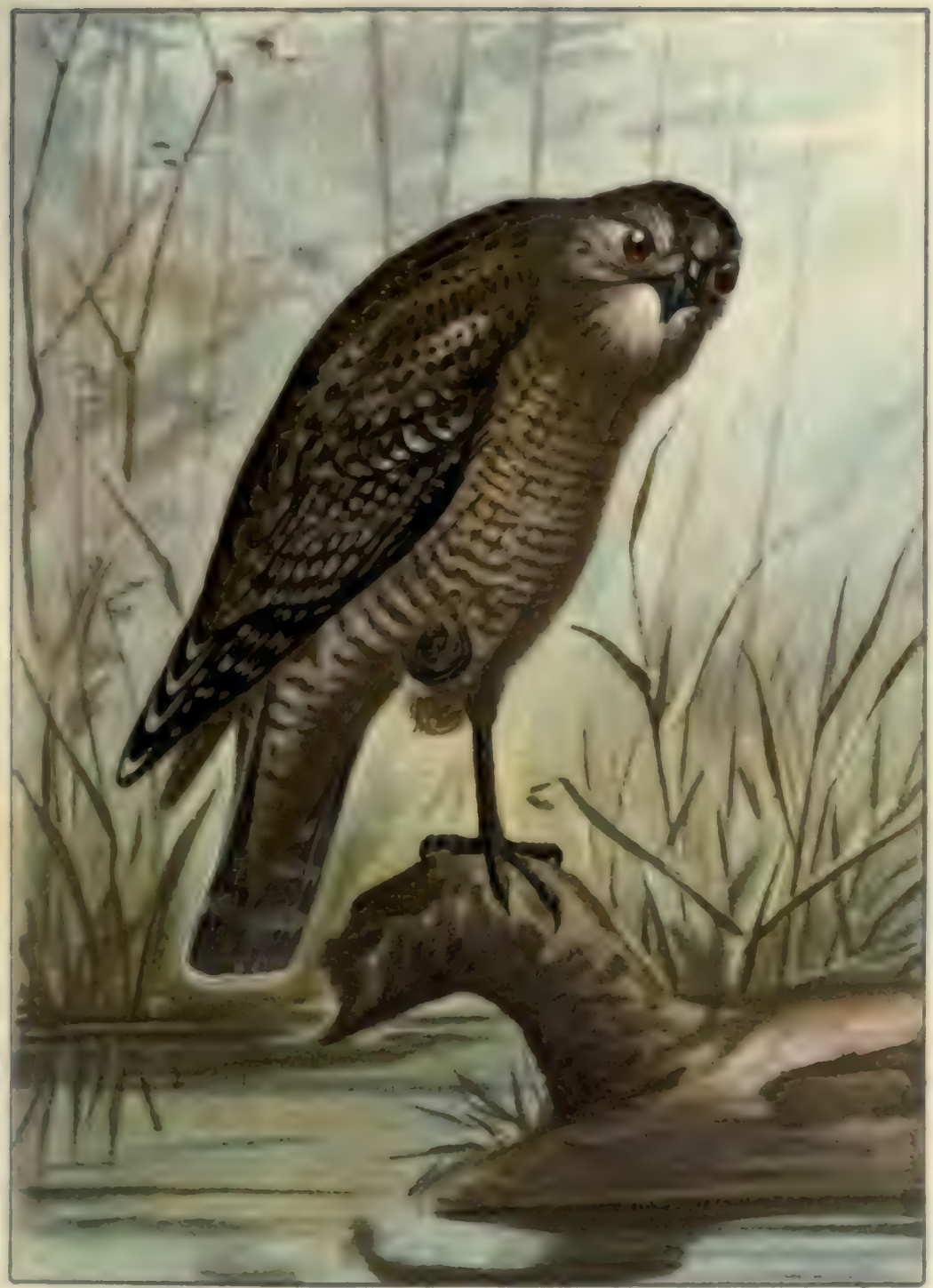

Phate XIV.

RED-8HOULDERED HAWR.

PAGE 104.

Leagth, 1900 Inches. Adult, upper parts blasklsh brown and rusty; lesser wing-coverts bright chestnut, wings and tail black and white; under parts rich rusty and white. Yonng, lese rusty on back, wings and tall largely rusty; under parts white, spctted or streaked with blackish. 

Chimney Swift, Least Flycatcher, Towhee, Purple Martin, Cliff and Bank Swallows, Black and White and Black-throuted Green W arllers, Oven-bird, House Wren, Brown Thrasher, Cathird, and Wood Thrush. This troop surely is not without musicians. In ringing tones they herald the victory of Spring over Winter.

The season of cold waves has passed, and the birds now appear with the regularity of ealendar events. From May 1 to 12 the migration reaches its height. It is a time of intense interest to the bird student, and happy is he who can spend unlimited time afield. Some mornings we may find ten or more different species that have come back to us, and each one may he represented by many individuals. The woods are thronged with migrants, and the scantily leaved trees and bushes enable us to observe them far more easily than we can when they travel southward in the fall. During this exeiting period we should see the Cuckoos, Nighthawk, Ruby-throated Humminglird, Crested Flycatcher, Kingbird, Wood Pewee, Baltimore and Orchard Orioles, Bobolink, Indigo Bunting, Rose-breasted Grosbeak, Scarlet Tanager, Red-eyed, Warbling, Yellow. throated, and White-eyed Vireos, Long-billed Marsh Wren, Wilson's Thrush, Redstart, Yellow-breasted Chat, Maryland Yellow-throct, Yellow Warbler, and others of its family.

Succeeding days will bring additions to the ranks of these species, and there will also be numerous small Warblers to look for, but by May 12 all our more familiar and common birds have arrived. During the rest of the month, as the transient visitants, or species which nest farther north, pass onward, birds gradually decrease in numbers, and by June 5 we have left only those that will spend the summer with us.

The migration over, we can now give our whole 6 
attention to a study of nesting habits. As a matter of fact, the nesting season begins quite as early as the spring migration, the Great Horned Owl laying its eggs late in February. In March and April other birds of prey and the earlier migrants nest. May migrants go to housekeeping soon after they reach their old homes, and by June 5 there are few species that have not nests.

With birds that rear two or three broods, the nesting season may extend into August. With those that have but one brood it may be over early in July. At this time we begin to miss the jolly, rollicking music of the Bobolink. Soon he will leave the meadow he has animated for two months, and with his young join growing flocks of his kind in the wild-rice marshes. His handsome suit of black and white and buff will be exchanged for the sparrowlike Reedbird dress, and in place of the merry song he will utter only a metallic tink. This note is characteristic of the season. Day and night we hear it from birds high in the air as they hasten to their rendezvons in the marshes.

July 1, Tree Swallows, who nest rarely if at all near New York city, appear and establish their headquarters in the Hackensack meadows - a first step on the migratory journey. July is a month for wanderers. The nesting season of most one-brooded birds is over; they are not yet ready to migrate, and pass the time roving about the country with their families.

In August birds are molting and moping. The careful observer will find that a few Warblers and Flycatchers have returned from the north and are passing southward, but, as a rule, August is a month to test the patience of the most enthusiastic bird student. Late in the month migrants become more numerous, but between the "flights" or "waves" there are days when 


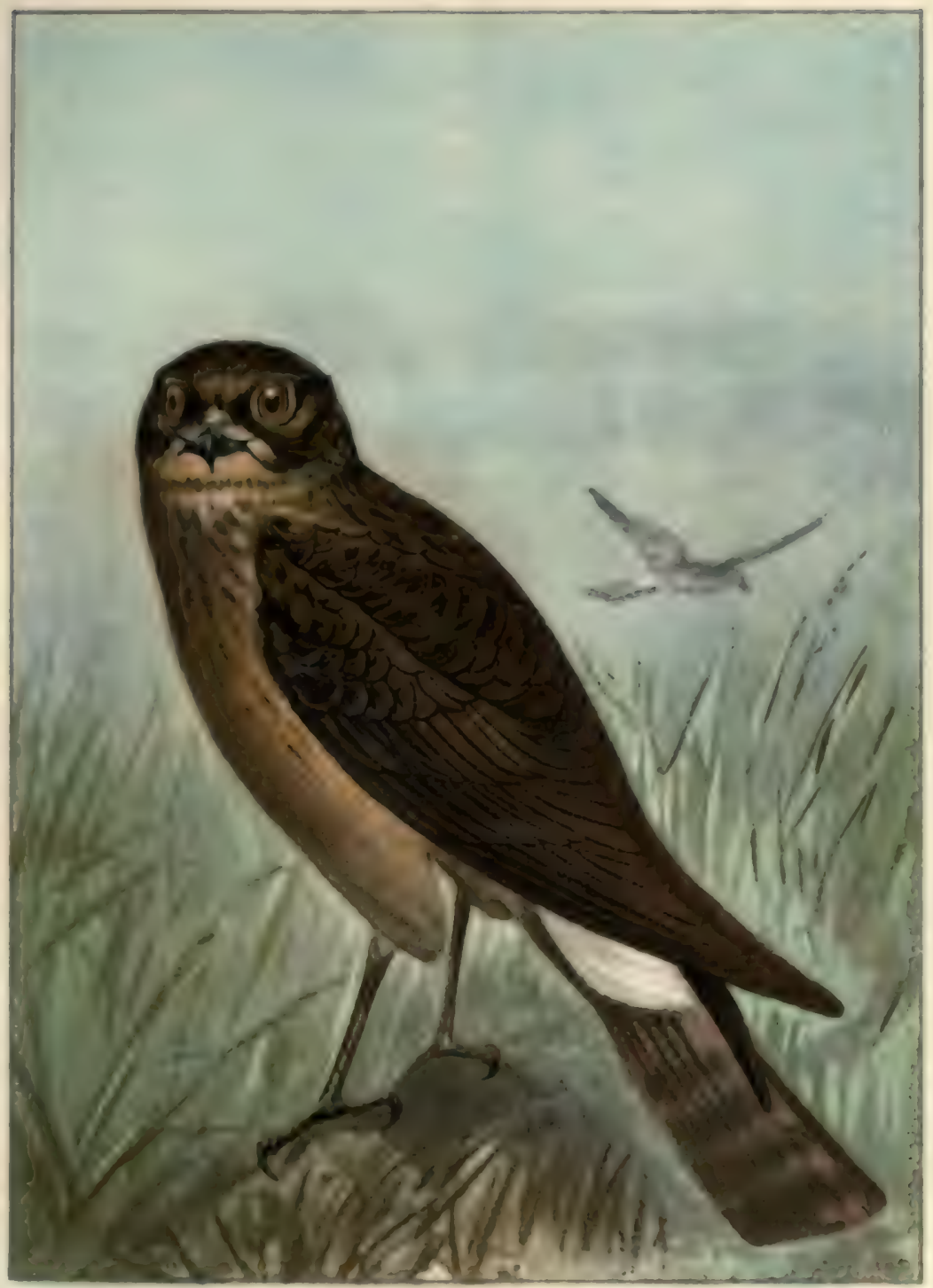

Prate XV.

Pagr 106.

\section{MARSH HAWK.}

Length, 20.00 Inches. Adult male, upper parts gray; under parts whlte with rusty apots; upper tall-ooverts white. Adull female and yoush, upper parts black and rich rusty; under parts rich rusty and blnok; upper tall-coverts white. 

one may tramp the woods for miles without sceing a dozen birds.

September is the month of Warblers. They come in myrials during the latter half of the month, and on favorable nights we may sometimes hear their fine-voicerl tarepus as they fly by overhead. About the 2:ith of the month our winter residents, the Junco, Winter Wren, Golden Kinglet, and Brown Creeper, will arrive.

The summer residents are now rapidly leaving us. In a general way it may be said that the last birds to arrive in the spring are the first to leave in the fall, while the earliest spring migrants remain the longest.

October and November are the months of Sparrows. They rise in loose flocks from every stubble or weed field, and seek shelter in the bordering bushy growth. Should the season prove warm, many of these hardy need-eaters will stay with us well into December, but at the first really cold weather they retreat southward.

This completes the merest outline of the movements of our migratory birds. It will be seen that in reality there are but few periods during the year when some event is not occurring in the birl world. As we accumulate records for comparison, and learn to appreciate their meaning, our interest in the study of migration will increase and be renewed with the changing seasons.

We have found, in this brief review, that our hirds may be placed in four classes, as follows:

1. Permanent Residents.-Birds that are represented in the same locality throughout the year.

2. Summer Rexidents.-Diris that come to us in the spring. rear their young, and depart in the fall.

3. Winter Residents.-Birls that come from the north in the fall, pase the winter with us, and return to their more northern homes in the spring. 
4. Transient Visitants.-Birds whose summer home is north and whose winter home is south of us. In traveling from one to the other they pass through the intervening region as "transients."

Manner of Migration.-The Oriole, who builds his swinging nest in your elm tree, will winter in Central America; the Bobolink, who seems so care-free in your meadows, must journey to his winter quarters in southern Brazil. But, unless accident befalls, both birds will return to you the following spring. We are so accustomed to these phenomena that we accept them as part of the changing seasons without realizing how wonderful they are. But look for a moment at a map, and try to form a mental picture of the Bobolink's route. Over valleys, mountains, marshes, plains, and forests, over straits and seas hundreds of miles in width, he pursues a course through trackless space with a regularity and certainty which brings him to the same place at nearly the same time year after year. How much of his knowledge of the route he has inherited, and how much learned during his own lifetime, is a question we may return to later; now we are concerned with actual methods of migration.

Immediately after, or even during the nesting season, many birds begin to resort nightly to roosts frequented sometimes by immense numbers of their kinds, with often the addition of other species. These movements are apparently inaugurated by the old birds, and are in a sense the beginnings of the real migratory journey. ()ther birds roam the woods in loose bands or families, their wanderings being largely controlled by the supply of food.

During this time they may be molting, but when their new plumage is acquired they are ready for the start. The old birds lead the way, either alone or asso- 


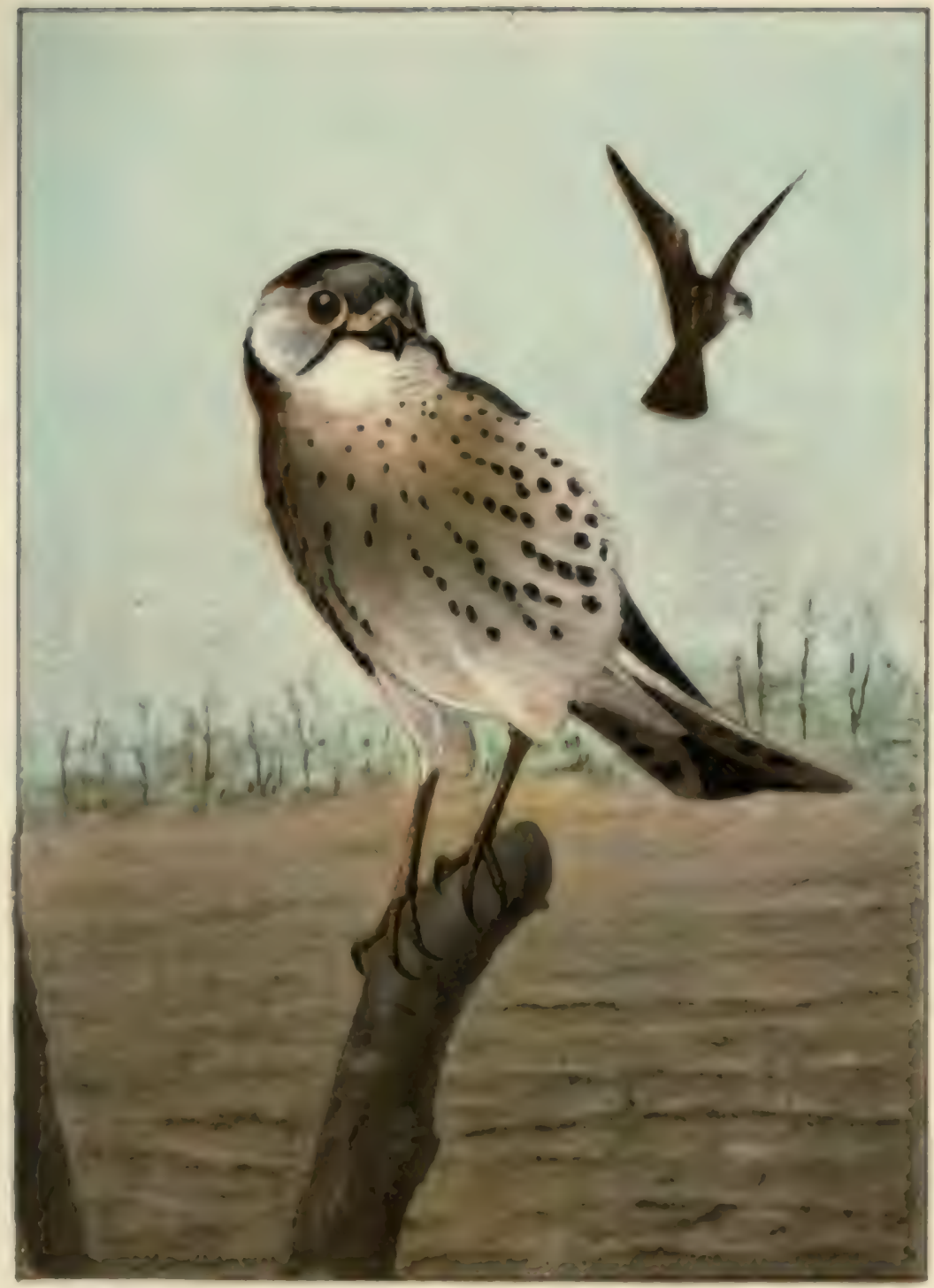

Prate XVI.

\section{BPARROW HAWK.}

PAGE 108.

Length, 11 no inches. Male, back reddish brown and black, wingcoverts slaty blue, tall reddish brown marked with binck and white; under parts washed with rusty and spotted with black. Femule, back, wings, and tall barred with redilish brown and black; under parto white, streeked with reddish brown. 

riated with the young. Some fly by day, some by night, and others by hoth day and night. This fact was first established by Mr. William Brewster, who, in his admirable memoir on Bird Migration, writes: "Timid, sedentary, or feeble-winged birds migrate by night, beeause they are either afraid to venture on long, exposed jour. neys by daylight, or unable to continue these journeys day after day without losing much time in stopping to scarch for food. By taking the nights for traveling they ean devote the days entirely to feeding and resting in their favorite haunts. Good examples are Thrushes (except the Robin), Wrens, Warblers, and Vireos.

" Bold, restless, strong-winged birds migrate chiefly, or very freely, by day, because, being accustomed to seek their food in open situations, they are indifferent to concealment, and being further able to accomplish long distances rapilly and with slight fatigne, they can ordinarily spare sufficient time lyy the way for brief stops in places where food is abundant and easily obtained. Lnder certain conditions, however, as when crossing large hodies of water or regions seantily supplied with food, they are sometimes obliged to trarel partly, or perhaps even exclusively, by night. Excellent examples are the Robin (Merult), Horned Lark (Otocmis), and most Icteride [Bobolink, Blackbirds, and Orioles].

"Birds of easy, tireless wing, which habitually feed in the air or over very extensive areas, migrate exclusively by day, because, being able either to obtain their usual supply of food as they fly, or to accomplish the longest journeys so rapidly that they do not require to feed on the way, they are under no neressity of changing their usual habita. The best examp'es are Swallows, Swifts, and Hawks."

While migrating, hirds follow mountain chains, coastlines, and particularly river ralleys, all of which become 
highways of migration. Through telescopic observations it has been learned that migrating birds travel at a great height. The exact height remains to be determined, but it is known that many migrants are at least a mile ahove the earth. From this elevation they command an extended view, and in clear weather prominent features of the landscape are doubtless distinguishable to their powerful vision at a great distance.

It is when fogs and storms obscure the view that birds lose their way. Then they fly much lower, perhaps seeking some landmark, and, should a lighthouse lie in their path, they are often attracted to it in countless numbers. Thousands of birds perish annually by striking these lights during stormy fall weather. In the spring the weather is more settled and fewer birds are killed.

Although birds are guided mainly by sight, hearing is also of assistance to them on their migrations. Indeed, at night, young birds, who have never made the journey before, must rely largely upon this sense to direct them. It is difficult for us to realize that on favorable nights during the migratory season myriads of birds are passing through the dark and apparently deserted air above us. Often they are so numerous as to form a continuous stream, and if we listen we may hear their voices as they call to one another while flying rapidly onward.

Some idea may be formed of the multitude of birds which throng the upper air on favorable nights during their migration by using a telescope. One having a twoinch object glass will answer the purpose. It should be focused on the moon, when the birds in passing are silhouetted against the glowing background. At the proper focal distance they appear with startling distinctness. In some cases each wing-beat can be detected, and with a large glass it is even possible to occasionally recognize the kind of bird. 


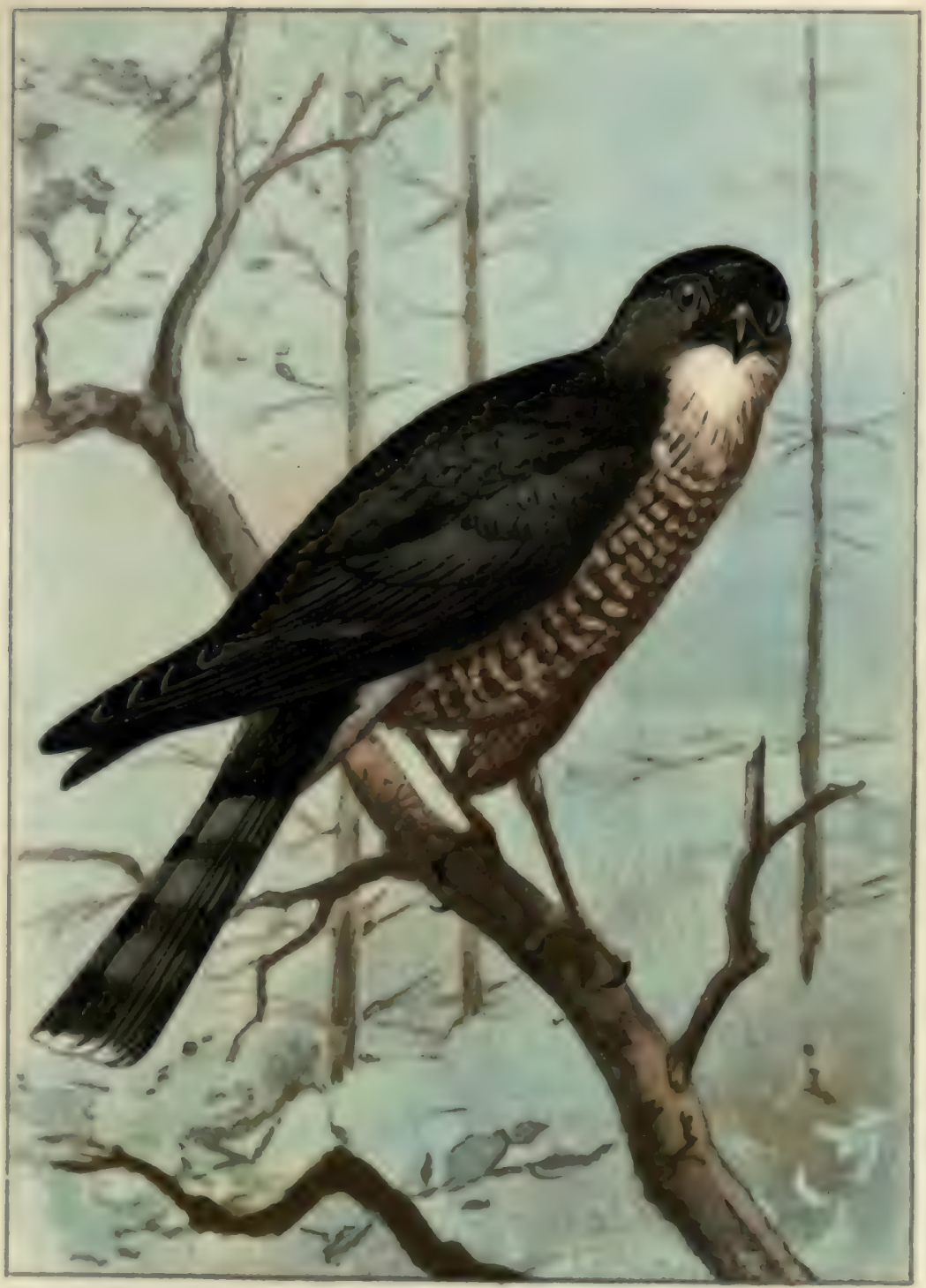

Prate XVI.

PAex 107.

SHARP-SHINNED HAWR.

Length of male, 11.25 inches; of female, 13.50 tnohes. Adwit, upper parts slaty gray; under parts white and rusty brown. Young, upper parts blacklah brown; under parts white, streaked with rusty brown. 

Ohservations of this kind should be made in Septem. ber, when the fall migration is at its height. On the night of September 3,1887, at Tenafly, New Jersey, a friend and myself, using a six-and-a-half-inch equatorial glass, saw no less than two hundred and sixty-two birds cross the narrow angle subtended by the limbs of the moon between the hours of eight and eleven. Otservations male several years later, in September, from the ohservatury of Columbia University, yielded closely similar results.

This nocturnal journey of birds may also be studied from lighthouses. On September 26, 1891, I risited the Bartholdi Statue of the Goddess of Liberty. in New York Bay, for this purpose. The weather was most favorable. The first bird was observed at eight o'clock, and for the succeeding two hours others were constantly heard, though comparatively few were seen. At ten o'clock it began to rain; and almost simultaneously there was a marked increase in the number of birds about the light, and within a few minutes there were hundreds where before there was one, while the air was filled with the calls of the passing host.

From the balcony which encircles the torch the scene was impressire beyond description. We seemed to have torn aside the veil which slirouds the mysteries of the night, and with the searching light exposed the secrets of Nature.

By far the larger number of birds hurried onward; others hovered before us, like IIumminghirds before a flower, then flew swiftly by into the darkness; and some, apparently blinded hy the brilliant rays, struck the statue slightly, or with sufficient force to canse them to fall dead or dying. At daybreak a few stragglers were still winging their way southward, but before the sun rose the flight was over. 
Origin of Migration.-Why do birds migrate? It is true that in temperate and boreal regions the return of cold weather robs them of their food, and they retrest southward. But many, in fact most, birds begin their southern journey long before the first fall frost. We have seen that some species start as early as July and August.. Furthermore, there are many birds that come to our Gulf and South Atlantic States to nest, and when the breeding season is over they return to the tropics. Surely, a lower temperature can not be said to compel them to migrate. Even more remarkable than the southward journey in the fall is the northward journey in the spring. Our birds leave their winter homes in the tropics in the height of the tropical spring, when insect and vegetable food is daily increasing. They leave this land of plenty for one from which the snows of winter have barely disappeared, often coming so early that unseasonable weather forces them to retreat.

I believe that the origin of this great pilgrimage of countless millions of birds is to be found in the existence of an annual nesting season. In my opinion, it is exactly paralleled by the migration of shad, salmon, and other fishes to their spawning grounds, and the regular return of seals to their breeding rookeries.

Most animals have an instinctive desire for seclusion during the period of reproduction, and when this season approaches will seek some retired part of their haunts or range in which to bring forth their young. Salmon may travel a thousand miles or more from the ocean, and, leaping the rapids or other barriers in their way, finally reach the headwaters of some river where their eggs may be deposited in safety. Seals migrate with regularity to certain islands, where their young are born. Even our domesticated Hens, Turkeys, Ducks, and Peafowl, if given freedom, will travel a greater or less dis- 


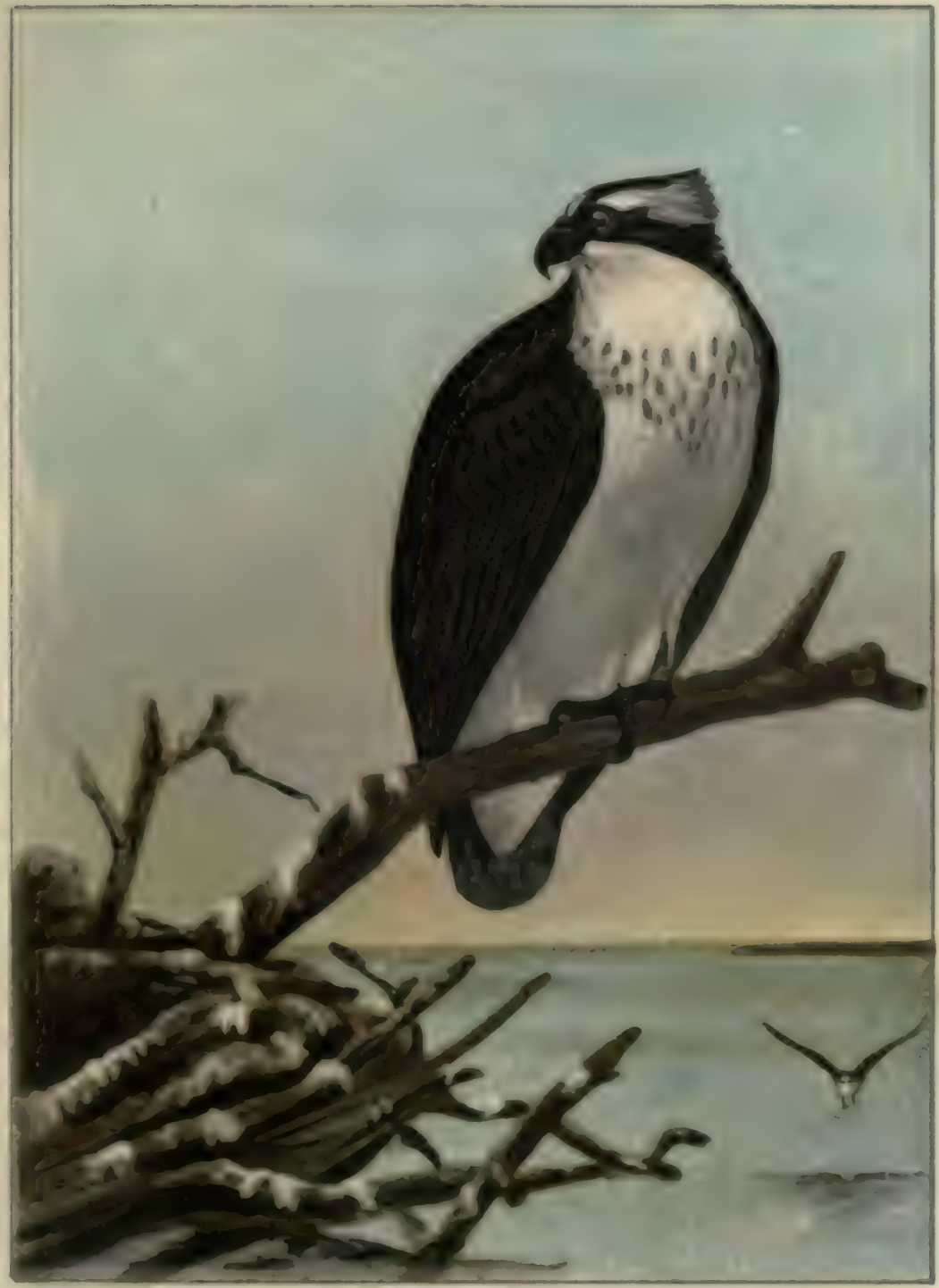

Puate XVIII.

Paes 107.

AMTRRTOAN OSPREX.

Length, 29.00 lnches. Upper parta brownish black; nape and under parts white; breast marked with graylsh brown. 

tance in search of a place where they may conceal their nests.

Many speeries of tropieal sca birds resort each year to some rucky islet, situated perhaps in the heart of their nunge, where they may nest in safety. This is mot migration as we understand the word; but, nevertheless, the object is the same as that which prompts a Ploser to travel to the arctic regions; moreuver, the movenent is just as regular. These sea birds pass their lives in the tropies, their presence or absence in any part of their monge being largely dependent upon the supply of ford. But, ss in the case of the Warbler which uigrates from South America to Labrador, they are ansually affected by an impislse which urges them to hasten to a certain place. This impulse is periodic, and in a sense is common to all birds. There is a regular neating senson in the tropies, just as there is a regular nesting season in tho anctic regions.

There is good reason, therefore, for the lelief that the necessity of securing a home in which their young could be reared wna, as it still is, the cause of migration. It must he rememberid, however, that birds have heen migrating for ages, and that the present conditions aro the result of numerous and important climatic changes. Chief among thene is doubtless the Glacial period. Indeet, Dr. Allen has stated, and the theory has been gen. erally accepted, that the migration of birds was the out. come of the Glacial period. Prior to those climutic changes which, legginning in the latter part of the Tertiary perionl, culnimated in the ice age, a warm temperate or suberopieal climste prevailed in the Arctic regions, and it was not necessary for biris to migrate. Driven southward loy the formation of ice, many species doubtiess becume extinct. As the ice receded liris followed it northward, only to retreat southwand ench year at the 
return of winter. Thus the halit of going north in the spring and returning in the fall was eventually formed.

As I have said, the existing conditions are the result of changes which have been active for ages. No species, therefore, has acquired its present summer range at one step, but by gradually adding new territory to its breeding ground. For example, certain of our Eastern birds are evidently derived through Mexico, and in returning to their winter quarters in Central America, they travel through Texas and Mexico and are unknown in Florida and the West Indies. Others have come to us through Florida, and in returning to their winter quarters do not pass through either Texas or Mexico. This is best illustrated by the Bobolink, an Eastern bird which, breeding from New Jersey northward to Nova Scotia, has spread westward until it has reached Utah and northern Montana. But-and here is the interesting point-these birds of the far West do not follow their neighbors and migrate southward through the Grest Basin into Mexico, but, true to their inherited habit, retrace their steps, and leave the United States by the roundabout way of Florida, crossing thence to Cuba, Jamaica, and Yucatan, and wintering south of the Amazon. The Bobolinks of Utah did not learn this route in one generation; they inherited the experience of countless generations, slowly acquired as the species extended its range westward, and in returning across the continent they give us an excellent illustration of the stability of routes of migration.

They furnish, too, an instance of one of the most important factors in migration-that is, the certainty with which a bird returns to the region of its birth. This is further evidenced by certain sea birds which nest on isolated islets to which they regularly return each year.

Of this wonderful "homing instinct," which plays so 


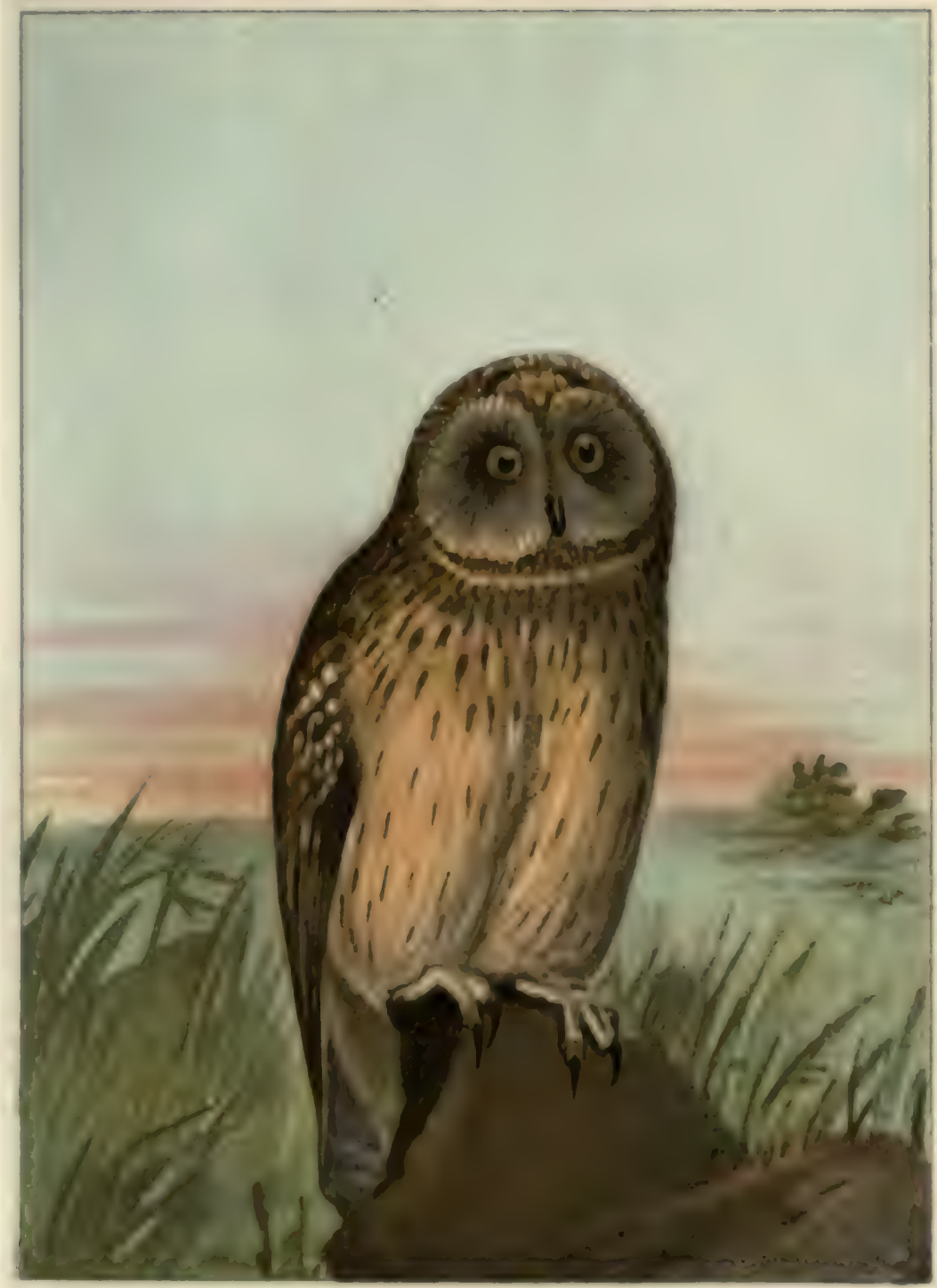

Puate XIX.

Page 100.

BHORT-BARED OWL.

Length, 15.60 Inohes. Upper parts black, buff, and rusty; under parts white and brownlah blnck; eyes yellow. 

vital a part in the migration of birds, I have no explanation to offer. We know, however, that it exists not only in birds but in many other animals. It is this instinct, ailed by the "heredity of habit," which guides a lird to its nesting ground. The Carrier Pigeon is taught its lines of flight by gralually extending its journeys; a species establishes its routes of migration by gradually extending its range. 


\section{CHAPTER V.}

\section{THE VOICE OF BIRDS.*}

Aside from the pleasure to be derived from the calls and songs of birds, their notes are of interest to us as their melium of expression. No one who has closely studied birds will doubt that they have a language, limited though its vocabulary may be.

Song.-Song is a secondary sexual character, generally restricted to the male. With it he woos his mate and gives voice to the joyousness of nesting time. In some instances rocal music may be replaced. by instrumental, as in the case of the drumming wing-beat of the Grouse, or the bill-tattoo of the Woodpeckers, both of which are analogous to song.

The season of song corresponds more or less closely with the mating season, though some species begin to sing long before their courting days are near. Others may sing to some extent throughout the year, but the real song period is in the spring.

Many birds have a second song period immediately after the completion of their posthreeding molt, but it usually lasts only for a few days, and is in no sense comparable to the true season of song. This is heralded by the Song Sparrow, whose sweet chant, late in February,

* See Witchell. The Erolution of Bird Sring (Macmillan Co.). Bicknell. A Sturly of the Singing of ()ur Birls: The Auk (New Fork city). vol. i, 1884. pp. 60-71, 126-140, 209-218, 322-332; vol. ii, 1885, pp. 144-154, 249-262. 


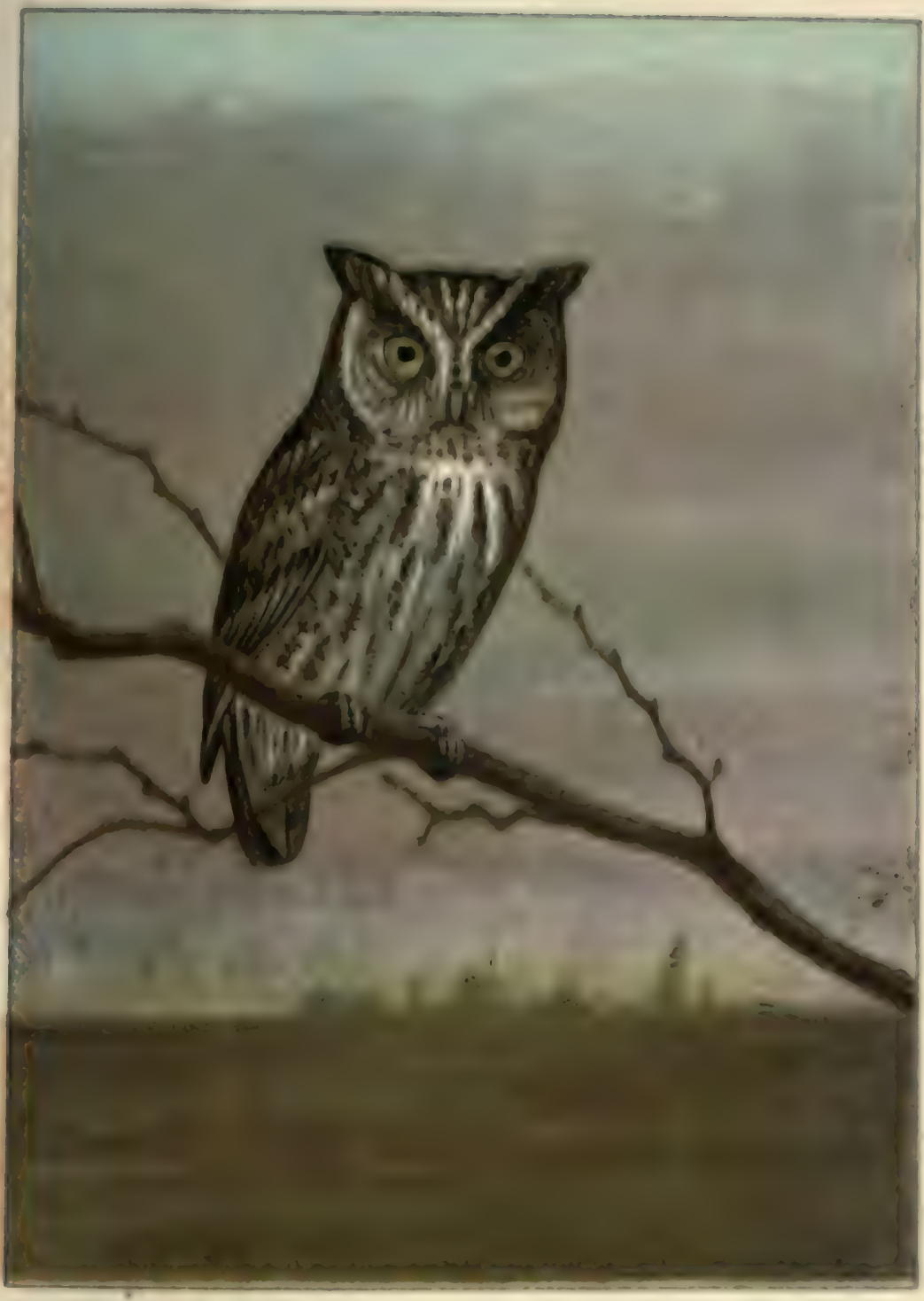

PLate XX.

Page 110.

SCRRECII OWL.

Length, 9-10 Inches. Upper parts gray, or bright reddich bmw, and black; under parts white, gray, or bright reddiah brown, and back; eyes yellow. 

is a most welcome promise of spring. Then follow the Rubins, Blackbirds, and other migrants, until, late in May, the great springtime chorus is at its height.

The Bubolink is the fint bird to desert the choir. We do not often hear him after July 5. Soon he is fol. lowed by the Veery, and each day now shows some frosh vacaney in the ranks of the feathered singers, until by August 5 we have left only the Wood P'ewee, Indigo Bunting, and Red-eyed Vireo-tireless songsters who fear neither millsummer nor midday heat.

Cull-Votes.-The cull-notes of birds are even more worthy of our attention than are their songs. Song is the vutburst of a special einotion; call-notes form the language of every day. Many of us are familiar with birds' songs, but who knows their every call-note and who can tell us what each call means? For they have a meaning that close olservation often makes intelligible.

Listen to the calls of the Robin and learn how unmistakably he expresses suвpicion, alarn, or extreme fear; how he signals cheerfully to his companions or gives the word to take wing. Study the calls of the Crow or Blue Jay, and you will find that they have an apparently exhaustless vocabulary.

It is supposed that birds, like men, do not inherit their language, but acquire it. Thus there are recorded instunces of young birds who had been isolnted from others of their kind, learning to sing whatever song they beard. On the other hand, it is said that a bird inherits its own notes, at least to some extent, aud, while it may not sing the song of its species perfectly, its song will still be sufficiently characteristic to be recognizable. Thero are, however, very few satisfactory obervations on this subject, and keepers of eage-birds have here an excellent opportunity for original inrestigation. 


\section{CHAPTER VI.}

\section{THE NESTING SEASON.*}

IF you would really know birds, you must study them during nesting time. At this season they develop habits that you will be surprised to learn they possess. The humble owner of some insignificant call-note now fills the rôle of a skilled musician. The graceful, leisurely Marsh Hawk gives vent to his feelings in a series of aërial somersaults over the meadows; the sedate, dignified Woodcock tries to express his emotions by means of spiral evolutions which carry him far above his usual haunts; the Night-Hawk dives earthward with needless recklessness; in fact, birds seem inspired by the joy of the season, and all the brightness of a May morning is reflected in their roices and actions.

Mating over, there follow the marrels of nest-building with its combined evidences of instinct and intelligence. In due time the young appear, and the bird, now a parent, abandons the gay hahits of the suitor, and devotes every waking monient to the care of its young.

Time of Nesting. - With most birds the nesting season is periodic and annual. With migratory birds it coincides with the season of the year when their summer homes are habitable. But we might suppose that the

* Read In Nesting Time, Little Brothers of the Air, and other works by Olive Thorne Miller. A-Birding on a Broncho, by Florence A. Merriam (Houghton, Mifflin \& $\mathrm{Co}_{4}$ ). 


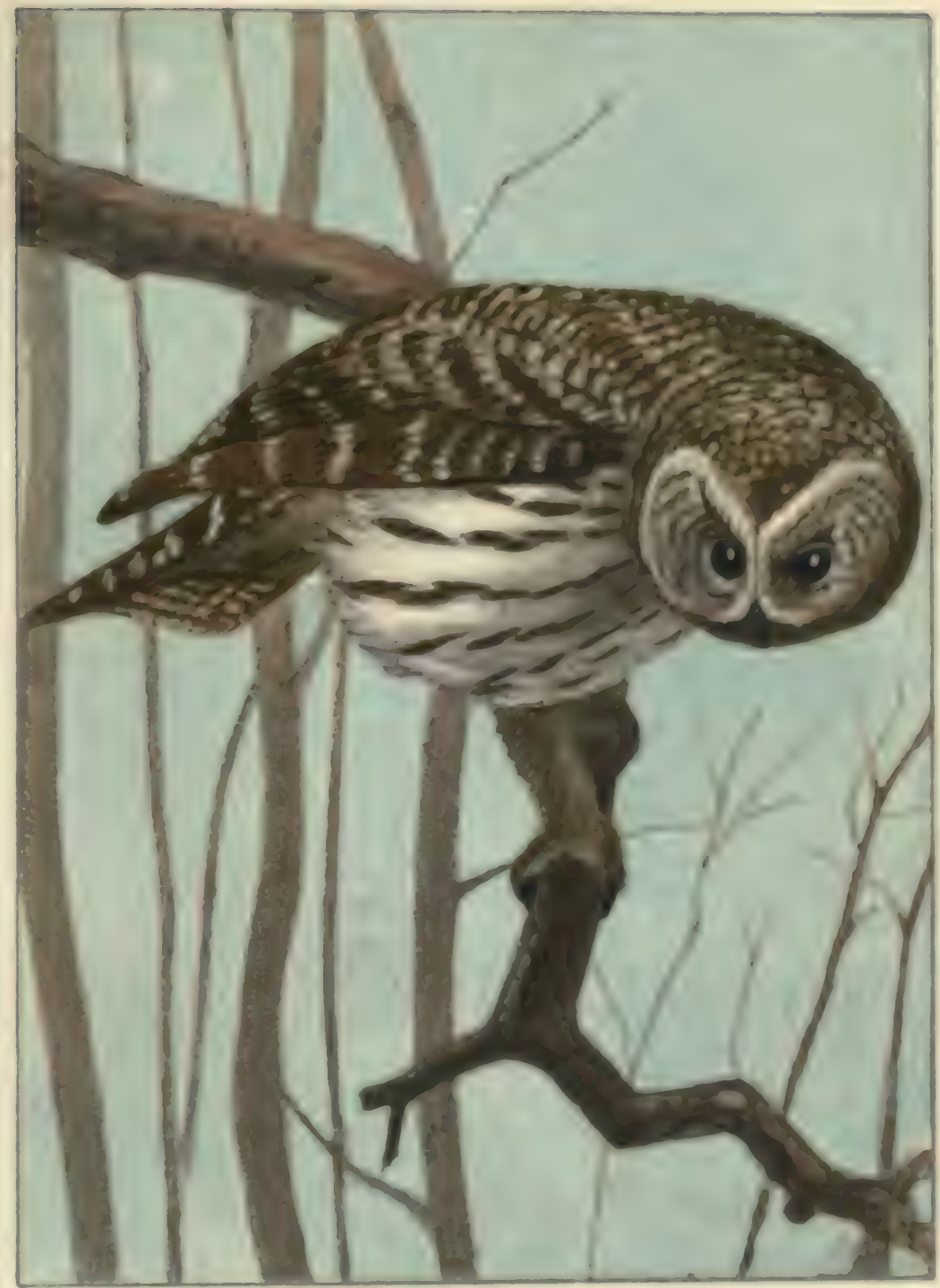

Puate XXI.

Pane 181

BABRED OWL.

Length, 20-00 Inchme Tpper parta blankiab bruwn and white : under parts white and blacklah tumwa; ry en black. 

permanent reaidents of the tropies, where seasonal changes are less marked, could nest at any time. Nevertheless, the breeding senson in the tropics :s as well defined as it is in more northern regions, and occurs with the return of summer, or the sesson of rains. It is therefore at a time of the year when food is most abundant.

There is an obvious necessity for this regularity. Old birds ean wander over large areas in search of food, but the young of many species must be fed in the nest, and their food supply should be both exhaustless and convenient of access.

Among our birls, the Hawks and Owls, whose young are fed on animal food, are the first birds to nest, while those which feed their young on fruit or insects wait until later in the year.

Muting.-Birds are ardent lovers. In their effort to win a bride the males display their charms of song and plumage to the utmost, and will even enter the lists to do battle for the possession of a mate.

It is not possible to describe here the many pecnliar customs of birds during the season of courtship. It may simply be said that every bird will then repay the closest observation. For the scientific-minded there is opportunity to secure evidence bearing upon the theory of Natural Selection; for every one there is endless entertainment in the human traits which birds exhibit.

The Nest.-The first step in nest-building is the selection of a site. There is almost no suitable location, from a hole in the ground to branches in the tree-tops, in which biris may not place their nests. Protection seems to be the chief desiderulum, and this is generally secured through concealment. Most birls hide their nests. Many sea birds, however, lay their eggs on the shores or cliffs, with no attempt at concealment; but, as a rule, 
birds that nest in this manner resort to uninhabited islets and secure protection through isolation.

Some birds nest alone, and jealously guard the vicinity of their home from the approach of other birds, generally of the same species. Others nest in colonies brought together by temperament or community of interests, and dwell on terms of the closest sociability.

The material usel by birds in building their nest: is as varied as the nature of the sites they select. The vegetable kingdom contributes much the largest share. Grasses, twigs, and rootlets are the standard materials; but plant-down, plant-fibers, bark, leaves, lichens, clay, spiders' webs, hair, fur, and feathers are also used, while in some cases a gummy secretion of the salivary glands furnishes a kind of glue.

Birds have been classified, according to the manner in which they employ these articles, as weavers, tailors, masons, molders, carpenters, felters, etc.

Sometimes both sexes assist in the construction of the nest, or one bird collects the material while the other adjusts it. Again, the female performs the task alone, aided only by the encouraging voice of the male.

The time of construction varies from one to two weeks to as long as three months in the case of the South American Ovenbird, who in June begins to build the nest it will not occupy until October. The Fish Hawk evidently believes in the value of a stick in time, and often repairs its nest in the fall.

Lack of space prohibits a discussion of the influences which assist in determining the character of birds' nests. They may be summarized as follows:

First, necessity for protection.

Second, conditions imposed by locality. These affect both the site and material, as illustrated by Dores, who nest in trees in wooded countries and on the ground in 


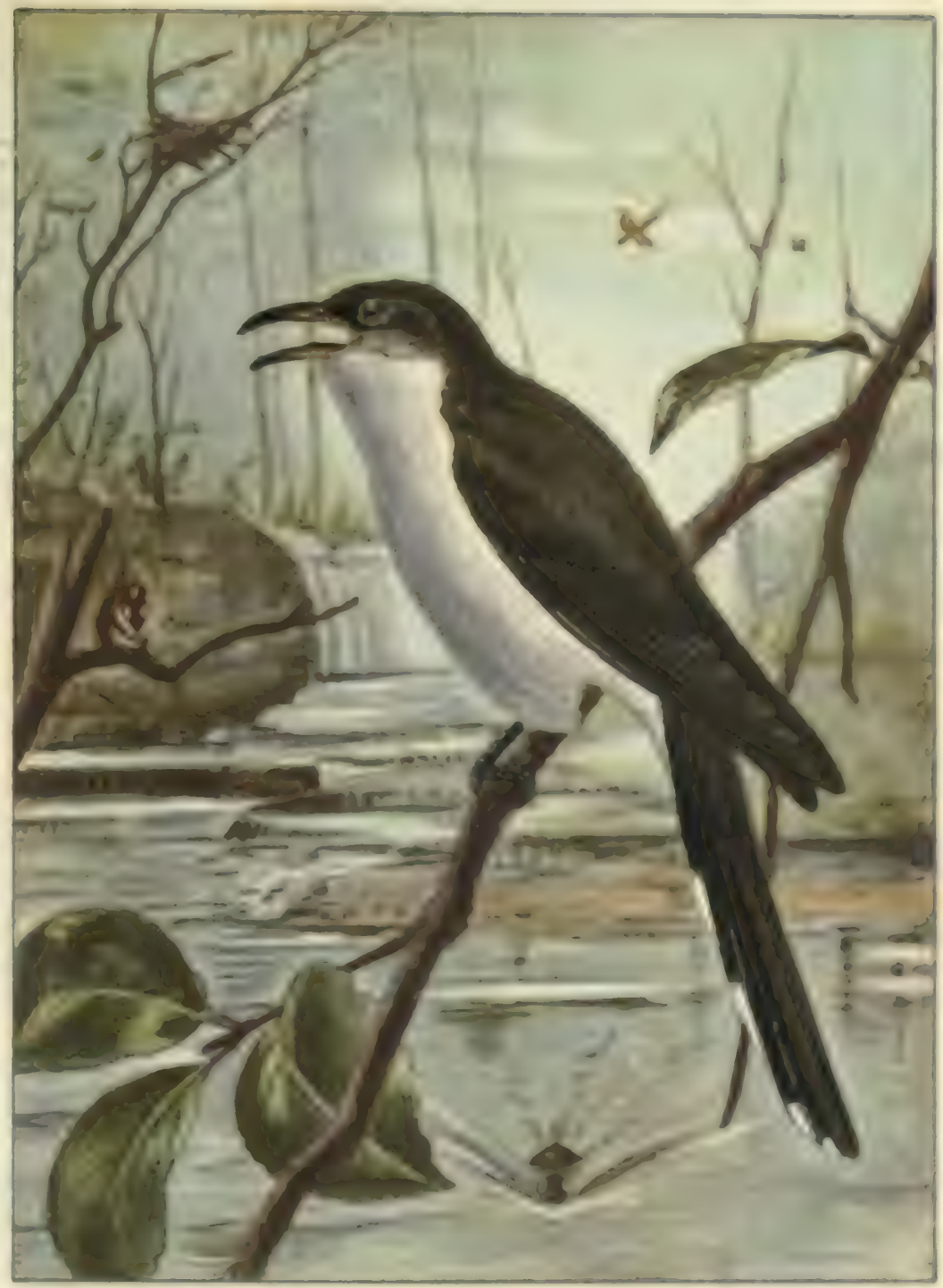

Puate XxII.

Page 112

\section{YRLLOW-DIHAD CUCKOO.}

Length, 12-25 Inches. Upper parte slowery allvebrown; outer tuls feathens blnck, Upped with whlto; under pare while; bow mandiles yellow. 

treeless regiona, and by birds who mubatiture atringa cotton, or rags for their usual nesting materialm.

Third, condition of the young at birch, whecthes feathered or naked. The young of what are sermed "precocial" birds are hatebed with a covering of downy feathens. Gulla, Duckn, Snipe, Chickens, Pas. tridges, and Quails are familiar memlnens of this group. Their young can run about soon after birth, and a well. formed nest is not needed. But the young of "altricial" birds are hatched practically naked and are neared in the nest, which is therefore not only a rereptacle for the eggs during incubation, but a bome. Thrushes, Sparrows, in fact all Perehing Birde, Woodpeckens, II ummingtinia and many others belong in this group of altricial binds.

Fourth, temperament, whether solitary or mocial. Ilawks, fierce and gloomy, nest alone, while the cheery, happy Swallows nest in colonies.

Fifth, structure of the bird. The tools-that is the bills and feet - of some birls are more servicenble than those of othen. We should not expect a Dove to builal the woven nest of an Oriole, nor a Humuninghirl to fahthion a Woodpecker's dwelling.

Sirth, feeding habit. In some few cares feeding habit may determine the character of the nest. Fir instance, Woodpocken, in securing their food from treen often make large excarationa, which it is guite natural they should have learned to use as nesta.

Seventh, inherited hahit, or instiuct. There soeme no reason to doubt that birds inherit their knowledge of nessbuilding, for in several cases where birds have twen taken from the neat and reared alone, they have afterwanl constructed a nest resembling that of their sperios It would therefore sppenr that inherited hahit is a fart. Through it we may explain not only the similarity in the nesta of the same species, but alao certain batita for 
which we can give no satisfactory reason. Thus the Crested Flycatcher's strange custom of using a cast snake-skin in its nesting materials probably originatel with the birds in the tropies, where it is still followed by nearly related species of Crested Flycatchers. With them there may be a reason for this habit, but with our bird, living as it does under entirely different conditions, it is doubtless only an inheritance, surviving even when the necessity for it has ceased to exist.

Eighth, change of habit. Some birds are influenced by changes in their surroundings, and alter their nesting habits when it proves to their advantage to do so. Chimney Swifts, who have exchanged hollow trees, in which they were exposed to their natural enemies, for the comparative safety of chimneys, are good examples. But a far better one is given by that prodigy in feathers, the House Sparrow. Is there any available site in which this thoroughly up-to-date bird will not place its nest? It has taken possession of even the hollow spaces about certain kinds of electric lamps, and has been observed repairing its nest at night by their light!

The Eggs. - Usually, little time is lost between the completion of the nest and the laying of the eggs. The number of eggs composing what oölogists term a full set or clutch ranges from one to as many as twenty. At the time of laying, the ovary contains a large number of partly formed eggs, of which, normally, only the required number will become fully developed. But if the nest be robbed, the stolen egg will frequently be replaced. The long-continuell laying of our domestic fowls is an instance of this unnatural stimulation of the ovary. Doubtless the most remarkable recorded ease of egg-laying by a wild bird is that of a High-hole or Flicker, who, on being regularly robbed, laid seventy-one eggs in seventy-three days! The eggshell is composed largely of carbonate of lime, 


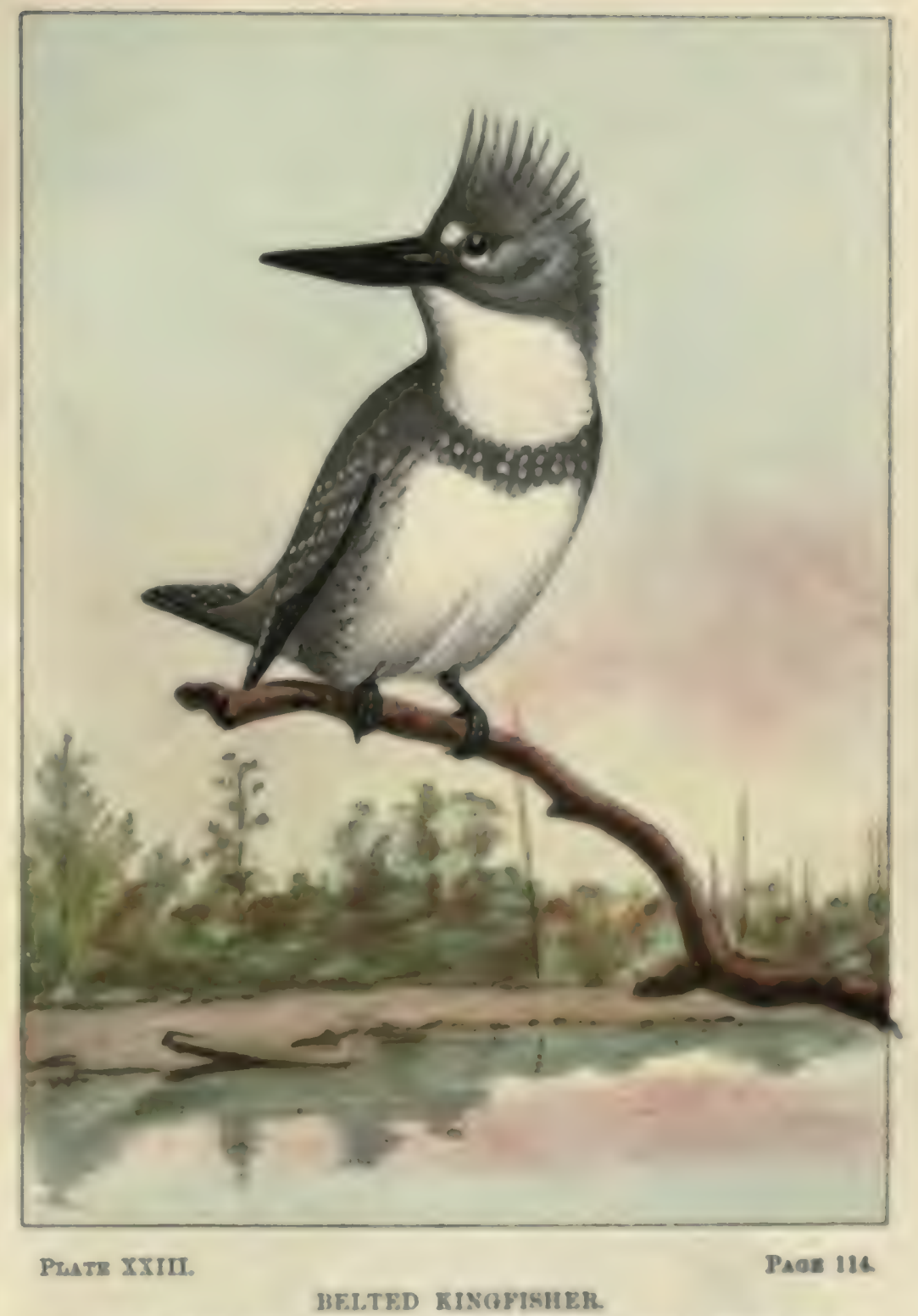

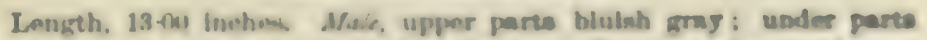

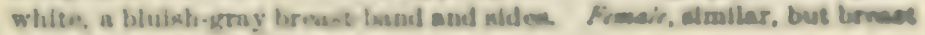
and sldes with reldtah bnown 

which is deposited in lnyers. The final layer varies grently in appearance, and may be a nugh, chaiky depanis, a in Cormorants and othen, or thin and highly polsabed, as in Woodpecken.

The colon of egans are due to pignuenta, remenuliting bile pigments, deponsted by durts while the egg is in the oviduct. One or more of the layens of sliell uny he prig. mented, and variations in tho tints of the sume pigment nay be caused by an added layer of earkeninte of lime, producing the so-called "cloudeal " or "whell markings."

While the eggr of the same species more or less closely resemble one another, there is often so great a range of variation in color that, unlese seen with the

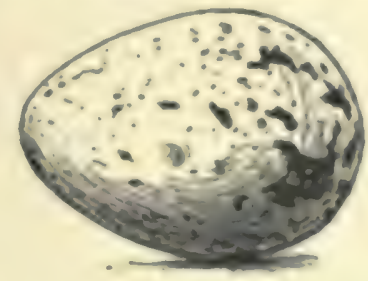

a

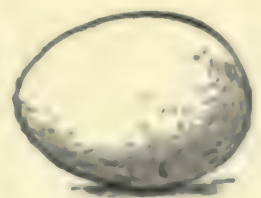

B

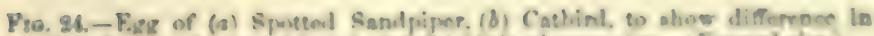

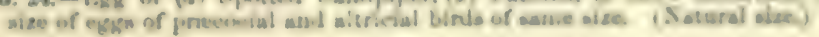

parent, it is frequently impasaihle to identify eggs with certainty. The egars of prucocial lirds, whose young are born with a covering of down and ean run or swim at birth, are, as a rule, proportionately larger than the eggn of altrieial birla, whose young are lorn in a much lesen advanced condition. This is illustruted by the accoun. panying fignre of the exgess of the Spottel Sandpiger and the Catbind.

The period of incubation is apparently elowely depend. ent upon the size of the egg, and varies from twelve daye in some Puswerine Birls in forty odd in the Ostrich abul, it is said, some tifty in the Kimu. 
Among some species both sexes share equally the task of incubation. In others, the female is longer on the nest, the male taking her place during a short period each day while she is feeding. Less frequently the female is not at all assisted by her mate, and in some cases-Ostriches, Emus, Phalaropes, and a few others-the male alone incubates.

The Young.-The care of the young and their mental and physical development afford us unequaled opportunities for the study of bird character. We may now become acquainted not only with the species but with individual birds, and at a time when the greatest demands are made upon their inteligence.

We may see the seed-eaters gathering insects and perhaps beating them into a pulp before giving them to their nestlings: or we may learn how the Doves, High-holes, and Hummingbirds pump softened food from their crops down the throats of their offspring.

The activity of the parents at this season is amazing. Think of the day's work before a pair of Chickadees with a family of six or eight fledglings clamoring for food from daylight to dark!

But the young birds themselves furnish far more interesting and valuable subjects for study. None of the higher animals can be reared so easily without the aid of a parent. We therefore can not only study their growth of body and mind when in the nest and attended by their parents, but we can isolate the young of præcocial birls, such as Chickens, from other birds and study their mental development where they have no opportunity to learn by imitation. In this way students of instinct and heredity have obtained most valuable results.*

\footnotetext{
* Read Lloyd Morgan's Habit and Instinct (Edward Arnold, New York city).
} 


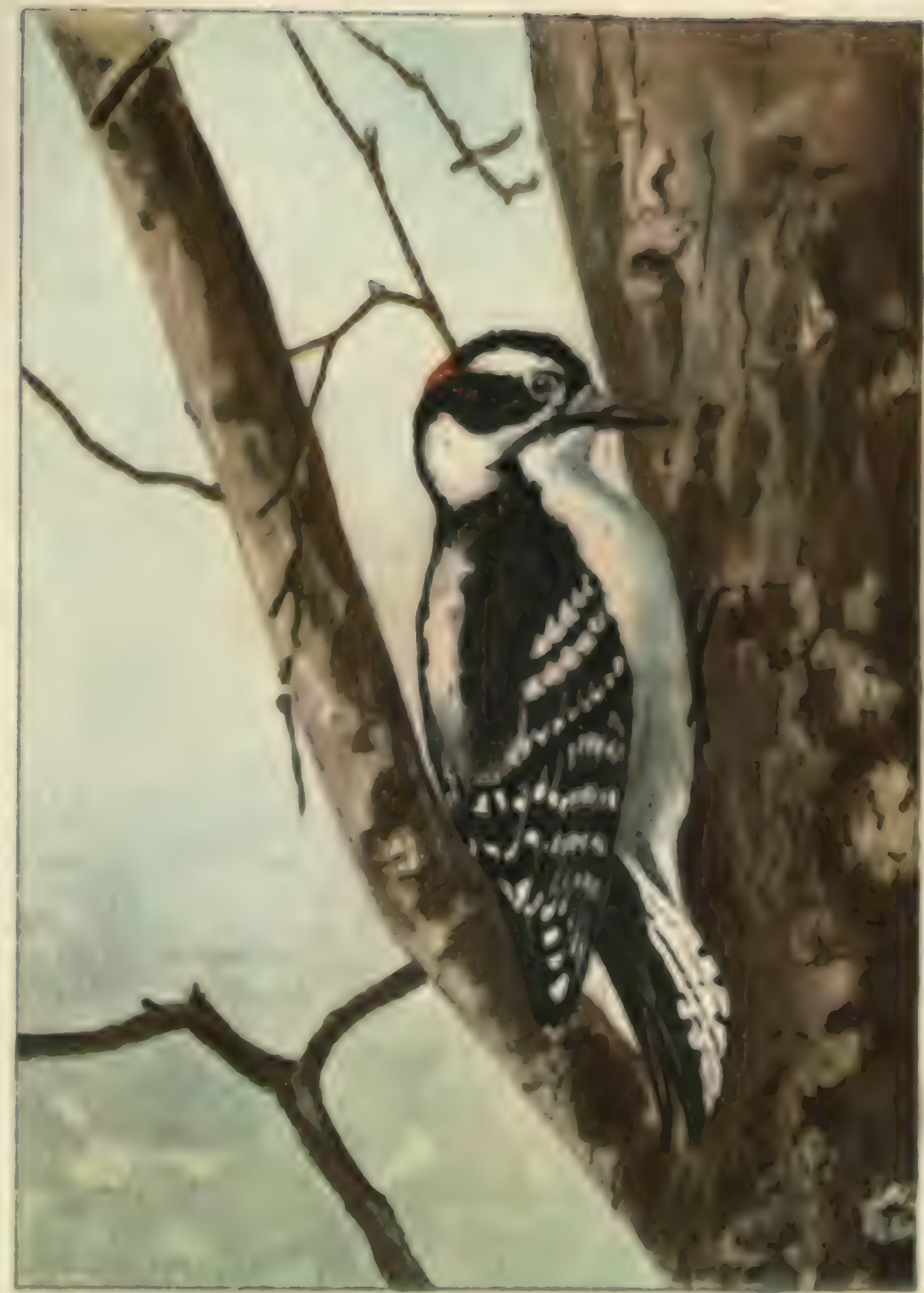

Puate XXIV.

Paex IL.

\section{DCWNY WooDrymit.}

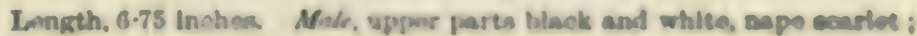

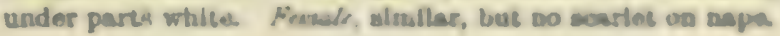





\section{CIIAPTER VII.}

\section{HOW TO INE.NTIFY BLRDQ}

Tws preceding outline of the events which may enter into a bird's life-history ha, I trumt, given some bilea of the possililities attending the study of birls in the field. We come now to the practical question of identifeation. How are we to find bink, and, having found them, how are we to learn their names ?

From A pril to August there is probnbly not a min. ute of the day when in a favorable lexality one can nus me or hear birds; and there is not a dny in the year when at lenst sone birds can not be found. In the the. ginning, therefore, the question of finding them is simply a matter of looking and listening. Inter will come the delightful hunts for certain rarer speries whose mequaine. ance we may make only through a knowledge of their haunte and habits.

Having found your hirl, there is one thing almolusely necessary to its identificntion : you muat me it definiedy. Do not deseribe a birl to an ornithologint an "browil, with white spots on its wings," and then expect him to tell you what it is. Would you think of trying to iden. tify flowens of which you eaught only a glimpee frum a car window in pasaing? You did not noe them definitaly, and at best yon can only carry their image in your mind until you have opportunity to see them in detail.

So it is with birds. Do not he discounigol if the books fail to show you the hrown bind with white spote is 
on its wings. Probably it exists only through your hasty observation.

Arm yourself with a field- or opera-glass, therefore, without which you will be badly handicapped, and look your bird over with enough care to get a general idea of its size, form-particularly the form of the bill-color, and markings. Then-and I can not emphasize this too strongly-put what you have seen into your note-book at once. For, as I have elsewhere said, "not only do our memories sometimes deceive us, but we really see nothing with exactness until we attempt to descrilue it."

It is true that all the birds will not pose before your glasses long enough for you to examine them at your leisure, but many of them will, and in following the others you will have all the excitement of the chase. Who knows what rare species the stranger may prove to be!

From your description, and what added notes on voice and actions you may obtain, the field key and illustrations on the succeeding pages should make identification a simple matter.* You should also take into consideration the sesson of the year when a bird is present, and not call a summer hird by a winter bird's name. The dates of migration given in the following pages will be of assistance here. They refer to the vicinity of New York city, where, in the spring. birds arrive about a week later

* The publishers' liberality hus resulted in securing bird portraits of unusual excellence. Mr. Seton Thompson is an ornitholngist as well as an artist; his suhjerts are personal friends. Ile has spured no effort to inake these pictures characteristic life sketches, and I venture to claim that, as a whole, they excel in truth and beauty any bird-drawings ever published in this country. 
than in central Illinois or at Washington, D. C., and a week earlier than at Bustun. In the full these conditions are reversed.

A Birl's Bingrapliy. - As a further guide to your observation a list of the priacipal detuils which enter into a birl's life-history is appended:

1. Descriptius (of siza, furm, color, and inarkings).

2. Ilacsts (up'und, lows lund, lakes, rivens, wowaln, Aelda, etc.)

8. Nurements (sluw of active, toups, walhs, creeps, swims, tail wagged, elc.).

4. Apprarasce (alert, pensive, enest enect, tnil dronped, etc.).

5. Dispostrtos (social, solitary, wary, unsunpicious, etc.).

6. Fuour (slow, rapied, direct, unduluting, soaring, sailing, flapping. etc).

7. Sove (pleasing, unattructive, enntinuous, short, loud, low. sung from the gronund, from a perch, in the air, etc; seacon of song).

8. Call-notes (of surprise, alurm, protest, warning, sigmaling, ete.).

9. Stasos (spring, fall, summer, winter, with times of arrival and departure, and variutions in uunbers).

10. Foop (berries, insects, seeds, etc, ; how secured).

11. Marrse (habits during cournship).

12. Nestiso (choice of site, muteriul, eonstruction, eggs, incubation).

13. Tuz Youvo (fmxl and cane of, time in the nest, notes, actions aight).

From observations of this kind, consisting of a simple statement of facts, you may philosophize accorling to your nature on the relation letween habit and structure, colons and haunts, an 1 inteligent adaptation to new conditions. Beware, however, lest you be led to draw faulty conclusions from insufficient olservation. Do not nake the individual stand for its spe ies, or the species for its family, and remember that one is warmated in theorizing only when the facts in the case are fucts indeed. 


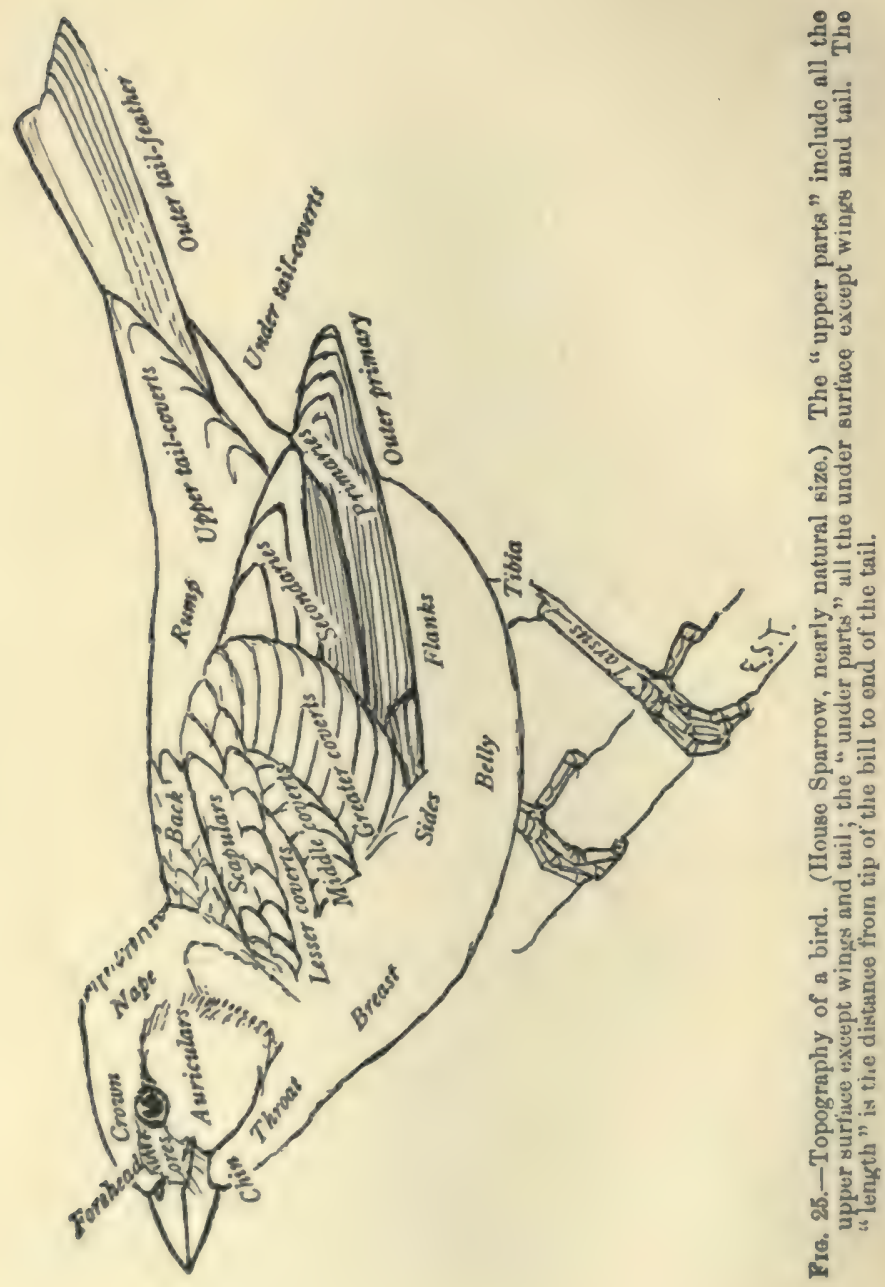




\section{CIIAPTER VIIL.}

\section{A FIELD KEY TO OUR COMMON LAND BIRDS}

Wuss you have seen a bird with sufficient definiteness to describe its color, form, and actions, reference to the following key will often prove a short cut to ito identity. This key is based only on adult males, who, beeause of their song, often brighter colons, and greater activity, are far more frequently observed than the fernales. But, knowing the male, you will rarely, during the nesting season, be at loss to recognize his mate.

In order to simplify the key, the water bir.Ja, Hawks, and Owlo are omitted, in the belief that they will be more readily identified by reference to the plates.

The use of the key may be illustrated by the following example: Let us imagine that you aee a Chipping Sparrow (Plate XLV) feeling about your downtep. You note his size, chestnut cap bordered by white, black bill, brownish, streaked back, and grarish white, unmarked under parts. Turning now to the key, you will see that by exclusion the bird belongs in "Sertion $V$ " of the "Third Group," and that it should he placed in sulsection " 1 " of this section, which includes birds haring the "under parts white or whitish, all one color, eriek. out streaks or spots." You have now two subdivivions to choose from-" A. Back without streaks or spots," and "B. Back brownish, streaked." Your bird falls under " $\mathrm{B}$," where again you have two subdirisione, " $a$. Cmwn rufolis or chestnut, without streakn," and " $b$. Crown not rufous or chestnut." Your bird should be referned to " $a$," where you will at once find it descrilved under " $a$ " as the Chipping Sparrow. 
It should be borne in mind that living birds do not look as long as they really are. The measurement of "length" is taken with the bird's neck and tail outstretched in a straight line. In life the tail may be raised or drooped, while the neck is drawn in or curved, making the bird look shorter than measurement shows it to be. Remember that the Robin measures ten inches, the House Sparrow six and one-fourth inches, and the Ruby-throated Humming-bird three and three-fourths inches in length, and you will have a basis for comparison.

\section{FIRST GROUP.}

BIRDS THAT FEED ON THE WING FOR LONG INTERVALS OF TIME WITHOUT PERCHING.

(Swallows, Swift, Nighthawk, Whip-poor-will.)

I. Size large, length over 9.00 inches; the sprear wings over $15^{\circ} 00$ inches in extent; generally seen only late in the afternoon or at dusk.

1. A bird of the air, flying high, often over housetops in cities: a conspicuous white spot in each wing; note, a loud, nasal peent; sometines dives earthward with a booming sound: May to Uet. . Nignthawz, page 118.

2. Haunts, near the ground, not often observed while feeding; call, given from a rock, stump, or similar perch, whip-poor-will, vigorously repeated; A pl. 25 to Oct. . . . . . . W нip-pook-wil., page 119.

II. Size smaller, length under 9.00 inches; the spread wings less than 15.00 inches in extent; may be seen at any time of the day.

1. Plumage entirely black.

a. Length 5.50 iuches; plumage sooty black; usually nests in chimneys ;

A pl. 25 to Oet. . . . . . . . . Chimery SwrFt, page 119.

b. Length 8-00 inches; glossy, bluish black; nests in gourds or houses

erected for its use; Apl. 25 to Sept. . . P Prrle Martin, page 161.

2. Plumage not entirely black; Apl. to Oot. . Swallows, pages $159,160$.

\section{SECOND GROUP. \\ CLIMBING AND CREEPING BIRDS. \\ (Nuthatches, Creepers, Woodpeckers.)}

I. Birds without stiffy pointed tail-feathers, that climb either up or down.

1. Length 6.00 inchen; hack gray, cap black, cheeks and under parts white; note, a nasal yank, yank; a permanent resident.

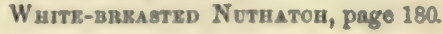


2. Length 4:50 inchea; back gny, cap black, alackinh atreak thmugh

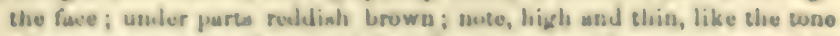

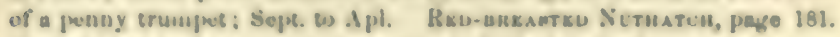

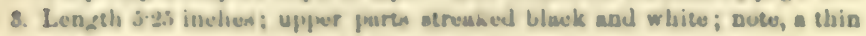
wiry ecr-erpan-aes; A pl. 25 to Uet.

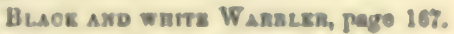

I1. Birds with stifly pointed tail-feathers, that al ways climb upward.

1. Lenseh \$65 inches: plumase dull trown and black; size suall, bill slenver; an ineonspieunun bird who winds his way up the erunks mearching for inveres' eggra, ete.; note, dou and muleaky: Sept. 25 to A pl.

Brow Coneren, page 178.

2. Plumago with moro or leas white, sizo langer, bill stouter, chinel-like, ores ured in hanmeriag.

A. Lesigeh $9 \cdot 75$ inches: head red, back black; flight showing a largo white pateh in the wing . . . Red-Hzaned Wuoprecerm, page 116.

B. Lengeh $[2-6)$ inches; crown gray; a rod band on the nape; flighe showing a white patch on the lower back and yellow in the winge; oflen flushed frous the ground; note, kie-yer . . Flscker, page 116.

C. Length 6.75 inches; crown black; back and wings black and white; note, abarp peek . . . . . DowsY W oodrecres, page 115.

\section{TIIRD GROUP.}

\section{BIRDS NoT IXClUUED IN TaE PRFCEDivo oRoups.}

(Blackbirds, Orioles, Sparrows, Vireos, Warblers, Thrushes, etc.)

Sectiox I. With yellow or orarge in the plumage.

Sectros 11. With red in the plumage.

Sectios III. With blue in the plumage.

Sectios IV. Pluınage conspicunusly black, or black and white.

Sisctiox V. Birds not included in the preceding sections.

\section{With yellow or orange in the plumage.}

1. Thruet yellow.

4. Throbat and hreast pure yollow, ecilhowt atruaks or mpota.

a. Lengeh 5.10 inches: eup, wings, and tuil black ; hack yellow; mong canarylike, monetimes utter.ul on the wing: tlight unduluting. froquensly scemupanied by the notes chica-roe, per-ehic-a-res: a pertnatwent revideut . . . . . . Ax. Golburiscu, page 148

b. Length $5 \cdot 6 s$ ituches: lower belly and wing-burs white; back olivegreen ; frezuenta the upper braseher generully in wrodlond; actions deliberate : mng loud and inu-jeal, utteresl slowly, often with pauses: "Seo uxe I I'm hero; whore ane you !"; May to Supe.

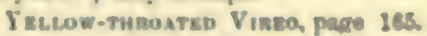

c. Length $5 \cdot 2.3$ inches: cheokn and furchemd black, bordered by any : upper partm slive-srewn: no wions-ham : huunta thicketa and under. growth: movementw nervous and active: call-note pil of chack;

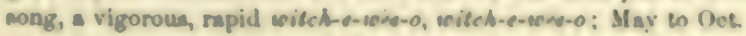

Manruxd Yelow-manost, page in. 
d. Length 7.45 inches; upper parts olive-green; no wing-burs; a white line before the eye; huunts thickets and uudergrowth; song, a striking mixture of whistles, chucks, and caros, sometimes uttered on the wing; May to Sept. . . . . Yelluw-Breasted Chat, page 172.

B. Under parts streaked with reddish brown; length 5.00 inches; general appearance of a yellow bird; haunts whrubbery of lawns, orchurds, second growths, and particularly willows near water; song, ratler loud, wèe, chèe-chèè-chèe, chèr-wèe, or chèe-chèe-chèe-chièe, wày-o; May to Sept.

YeLLOW WARBLEน, page 168.

C. Breast yellow, with a conspicuous black crescent; length 10.75 inches; haunts fields and meadows, larguly terrestrial; flight quail-like, outer tail-feathers white, showing when on the wing; song, a loud, musical whistle; a permanent resident. . . . Mradowlark, page 136.

2. Throat white.

A. With yellow on the sides.

a. Length 5.50 inches; rump yellow; breast streaked or spotted with black; tail-feathers marked with white; note, a characteristic tchip; Sept. to May, usually rare or local in winter.

Myrtee W Arbler, page 168.

b. Length 5.00 inches; no black on under parts or white in the tail : yellow extending along the whole sides; back olive-yreen, iris white; haunts thickets; call, an emphatic "Who are you, eh?"; May to Oct.

White-EYED Virko, page 16 .

c. Length 5.25 inches; tail and wings banded with yellow, showing conspicuously in flight; haunts woodland; movements active, much in the air, tail frequently spread; May to Oet. Kedstart, page 169.

$B$. No yellow on sides.

a. Length 6.75 inches; a yellow line from the bill to the eye; crown black, with a white stripe through ita center; haunts in and about thickets and bushy woodlands: song, a high, clear, musical whistle; call-note, chink . . . . White-throated SPARRow. page 143.

b. Length 4.00 inches; a yellow, or yellow and orange crown-putch, bordered by black; flits restlessly ahout outer limbs of trees and hushes; note, a fine $t i-t i$; Uet. to A pl. Golden-crowned Kinglet, page. 181.

3. Throut neither yellow nor white.

A. Length 12.00 inches; white rump and yellow in wings showing conspicuously in flight; a black breast-hand; note, a loud kie-yer.

Fucxin, page 116.

B. Length 9.00 inches; crested; brenst ashy, belly yellow; tril-feathers largely pale brownish red; haunts upper branches in woodland; note, a loud questioning or grating whistle: May to Sept.

Crested Flyoatoher, page 128.

C. Length 7.50 inches: throat and head black; breast, helly, and lower back deep orange: haunts fruit and shade trees; song, a loud, ringing whistle; May to Sept. ..... Baltimore ORTule. page 131.

D. Length $7 \cdot 20$ inches; crested; grayish hrown; a black line through the eye; tail tipped with yellow; generally seen in amall flocks : note thin and werk . . . . . . Cedar Waxwive, page 161 


\section{With red in the plumago.}

3. With rod on the undor parta.

A. Throat red.

a. Lengeh F.25 inctien: wingw and tail black; rewt of plumage bright scarlet; call-sote, elip-elirs; May to Bept.

BCAMLE⿱ TAYseEth, page 186.

8. Length 6-20 inehes: dull. pinkiah red, wirgos and tail browniah; frequestity seen feeting on buts or blowoms; call-note, a wharp chink, onea umered durisg tlight; song, a sweet, Howing wartle.

Power Fixos, pago 149.

c. Length 6.90 inches; dull red or green tinged with red; randibles eromed; seuerally seen in tlouks; feuds on pine conen.

Ax. Cmoannrz, page 14\%.

1. Longeh 5.80 iuches: a red crown-cap: back streaked black and browu; breast rowy; foeds on seeds or catkins; Nov. to Mch.

L Throat black.

Reprozl, page 148.

a. Length 8.00 inehes; breast rose-red, rest of plumage black and white; song loud and musical; call-note, peek; May to Sept.

Rour-breatrev Gronazax, page 180.

8. Lonpth 8.00 inches: a conppieuous crest; region sbout the base of the bill black; rest of the pluningo and bill red; song, a clear whinele; resident from Now York city southward.

Carabizak page 158.

c. Length 5.40 inches: wingm and tail banded witl orange-red, showing conspicuously in flight: movements active; much in the air; tail frequently apread; haunts woodland; May to Uet.

REDeram, page 169.

2. No red on the under parts.

A. Length $v:$ as inches: black; shoulden red; haunts manshes; migrates in flews: Meh. to (Net. . . . Rav-wisoet Blacksirn, page 132. B. L.ength 525 inches : crown-cap red; chin black; rewt of under parts strvaked with blackish; feeds on meeds and catkina; Nov. to Mch.

Reprous, (im.), page 146.

C. Length 400 inchea; under parts whitiwh: back olive-green: a ruby erown-patwh; eye-ring white; movernentw rentlesa, wings thitted trervouwly ; call-note, met; wong remarkably loud and musical; Scphe. and

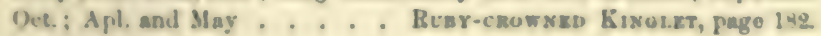

\section{With blue in the plumage.}

A. Langth 11 wo inehes; a conspicuous crest; upper parts dull the; under parto whitish; a black patch on the breast.

BLex Jat, page 180.

B. Length 7.01 inches: upper parts brighe blue; under parts cisnamonbrown .............. Blexetso, page 186.

C. Lengeh S.30 inchea ; entire plumage indigo-blue; Mag to ÓcL

Ixdico Bextroe, page 158

D. I.engeh 13.00 ; blutah gray ; haunce near water; feevls on thah, which

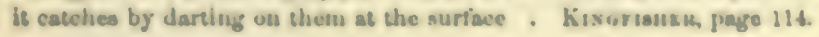




\section{Plumage congpleuously black, or black and white.}

1. Bluck and white birds.

A. Throat black.

a. Lenyth over 600 incher.

a. Entire under parts black; nape buffy: rump white; a musical dwoller of tields and mentows; frequently sings on the wing: May to Sept. . . . . . . . . Boboline, page 134 $a^{2}$. Bruast rose-red; rest of the plumage black and white; song rapid, loud and musical; call-note, peek; a tree dweller in rather open woodland; May to Sept.

Rose-BREA8Ted Grosbeax, page 150.

as. Sides reddish brown; rest of the plumage black and white; callnote, chewink or towhide; inhabits the undergrowth; often seen on ground scratching among fallen leaves; Apl. 25 to Oct.

TowнE, page 151.

6. Length under 6.00 inches.

b1. Crown black: cheeks white; back ashy; unstreaked : call, chicka-dee, or a musical, double-noted whistle; a permanent resident.

B. Throat and other parts white or whitish.

C'horadze, page 179.

a. Iength 8.50 inches; upper parts blackish slate-color; tail tipped with white: a bird of the air, catching its insect food on the wing, and occasionally sallying forth from its exposed perch in pursuit of a passing Crow; note, an unmusical, steely chatter, May to Sept.

KLNeBird, page 122.

b. Length 6.90 inches: upper parts washod with rusty; gencrally seen in Hocks: terrestrial; Nov, to Mch. . . . SNuwrlake, pago 147.

2. No white in the plumage.

A. Length 19.00 inches; jet black . . . . Axr. CRow, page 128.

$B$. Length 12.00 inches; black with metallic reflections; iris yellowish; migrates in tlocks: nest usually in colonies in enniferous trees: voice cracked and reedy; tail "keeled" in short Hights; a walker; Mch. to Nov. . . . . . . . Purple Graokle, page 188. C. Length 9.50 inches; shoulders red; haunts marshes; call, kong-quèrrez: Mch. to Uct. . . . . Ren-winged BlackBirn, page 132.

D. Length $7 \cdot 90$ inches; head and neck coffee-brown; frequently seen on the ground near cattle; Mch. to Nov. . . . . . Cowbird, page 137.

V. Birds not Included in the preceding sections that is, plumago without either yellow, orange, red, or blue; not conspicuously black, or black and white).

1. Under purts white or whitish, all one color, without streaks or spots.

A. Back without streaks or spots.

a. Back olive-green: gleaners, exploring the foliage for food or flitting about the outer branchen.

a. Length 6.25 inches; $a$ white line over the eye bordered by a narrow black one; cap gray : iris red : aong, a rambling recitative: "You noe it-you know it-do you hear me?" etc.: May to Uct.

RED-EYED ViREo, page 164. 
4. Longth $5 \div 3$ inchen: a whito line over the eyo not bordered by black ; profurs tho upper branches of rowa of eluns msad other whede trees: cong, a rich, unbroken warblo with an aleo undertono; May to sept. . . . . . . W Whasure Vizeo, page 105. a. Length 400 inchen; no whito line over the eyo; eyc-ring and wing-hera white: a tiny, unsumpicioun bird: thits about the outer branelies of trees and shrubs; wings twikhed nervousty; note, cack; cong, a retuarkmbly loud, murieal whistle; Sepe and Oet.; Apl. and May. . . . Renv-enewren Kiverxt, prage 192.

6. Back olive-green or duaky olive; flyeutehers who eapture their prey on the wing by durting fur ih and while perehing are quiet and ereet. 8. Lengeh 700 inchem: freyuently found nesting under bridges or aberut buildingn: emwa llackiah: tail waggod nuriously; tooter,

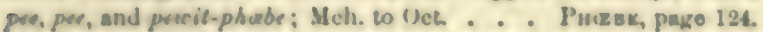
80. Length 6:50 inches: bausth wooded growths: now, a plaintive peo-a-uree: May w Sept. . . . W Wod P'rwer, paugo 126,

83. Length 5.40 inches; haunts orchants, lawna, and open woodlunds; note. chabic, chebic . . . . Lenot Flrcatcuzh, pago 125.

a. Back gray or bluivh gray.

c. Length 6.30 inches: a gray, creatod bind; forehead black; no white in the tail; notes a whistled peto, peto, or hoame do-de-de-do: revidens from Now York city southward . . Turres Tiт, page 180.

c. Length 8.50 inches; s wite band at the end of the tail; a concealed orange-red crest; a bird of the air, entching its insect food on the wing, and occasionally mallying forth from its exposed perch in purnuit of a paswing Crow: note, an unmuxical, etcely chatter; May to Sopt. . . . . . . Kisoasend, page 1Se

2. Back brown.

d). Length 5.00 inches: a nervous, reatleas, excitable bind; tail often carried enect: sonk sweet, rapid and rippling, delivered with abnn don ; Apl. 25 to Oet. . . . . . . Hotar W wax, page 173.

d. Length 12.25 inches; alim, browniah hirds with long tails; flight short and noiseless; perch in a tree, not in an exposed position;

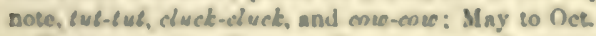

Yrluow-arlezd Cecroo, Blackaillev Crezoo, pages 112, 113.

B. Rack hrowniah, mtreaked.

a. Crown rufous or ehestnut without atreaka.

a. Lenzth 5-25 inehes; bill bluck: a whitiah line over the eye; s faniliar bird of law no and door-yanln : unng, a monotonous chippychippy-chippy: Apl. to Nov. . . Currive Sparmow, page 14.

a. length sto inches: hill redaliah brown, back rufous or rufousbrown: wing-hans and eye-ring whitimh : hauntw dry, bushy theldo and pasturen : mong, a muxical, plaintive eler-tece, chor-ucee, ehon

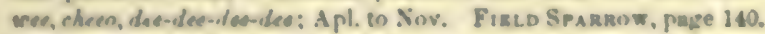

a. l.ength 5.90 inches: forcheml black: enown and wings chmatnutrufous: flanks palo grayimf bmorn; haunes manches ; song, a rapidly repented wowe-weet-weet, esc; Mch. to Niov.

8waxe Bpannow, page 282 
b. Crown not rufous or chestnut:

63. Lenyth 6.75 inches; crown blackish, with a central whitish stripo; throat white; breast gray: a yellow spot before the eye; haunts in and about thickets and bushy wooulands; song, a high, clear, musical whistle; call-note, chink.

White-throatev Spakrow, page 148.

62. Length 5.20 inches; bill slender; a white line over the eyo; tail carried erect; haunts reedy marshes; call-note scolding : soug rippling; May to Oct.

2. Under parts white or whitish, streaked or spotted.

Love-sulded Marsh WrEx, page 177.

A. Back streaked.

a. Length $6 \cdot 10$ inches; outer tail-feathers white, showing conspicuously when the bird Hies; haunts dry fields and roudsides; song nuusical; Apl. to Nov. . . . . . . . Vesper Sparrow, page 141.

b. Outer tail-featbers not white.

b3. Length 6.30 inches; breast with numerous spots tending to form one large spot in its center: haunts on or near tlie ground, generally in the vicinity of bushes; call-note, chimp; song musical; a permanent resident . . . . . . Songe Srarrow, page 188. 62. Length 6.35 inches; breast grayish with one spot in its center; Oct. to Apl. . . . . . . . TREz SPARrow, page 146.

B. Buck not streaked; breast spotted.

a. Length 11.40 inches; tail 5.00 inches; wing-hars white: upper parts, wings, and tuil bright cinnamon-brown; haunts undergrowth; sings from an exposed and generally elevated position; song loud, striking, and continuous; Apl. 25 to Oct. . Brown 'Turasher, page 175.

b. Length under 9.00 inches; tail under 3.00 inches; no wing-bars; back reddish or cinnamor-brown.

b2. Length $8 \cdot 25$ inches; breast and sides heavily marked with large, round, black spots; head and upper back brighter than lower back and tail ; call-note, a sharp pit or liquid quirt; Slay to Uct.

Wood Thrush, page 184.

69. Length $7 \cdot 15$ inches; breast with wedge-shaped black spots; sides unspotted, washed with brownish ashy; tail reddish brown, brighter than back; call-note, a low chuck; A pl. 10 to May 10; Oct. and Nov. . . . . . . . . Ireurt Tarush, page 185.

63. Length 7.50 inches; upper breast lightly spotted with small, wedgeshaped, brownish apots; tail the same color as the back ; sides white; call-note, a clearly whistled wheè ; May to Sept.

WiLson's Thausu, page 188.

a. Length under 9.00 inches; tail under 8.00 inches; no wing-bars; back olive-green.

c. Length $6 \cdot 10$ inches; center of crown pale browniah bordered by black; haunts on or near the ground in woodland: a valker; song, a ringing crescendo, teacher, teacher, TEACuER, TEACIIER, TEACHEK; May to Sept. . . . . UVEN-BIRD, page 170. 


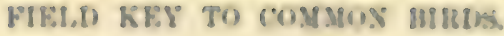

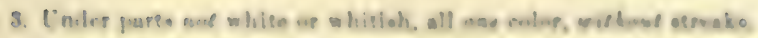

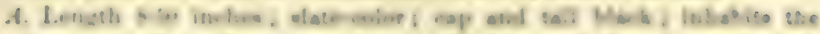

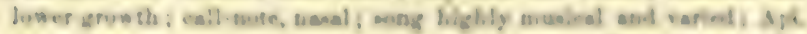
as to Oet.

Caravia pare 182

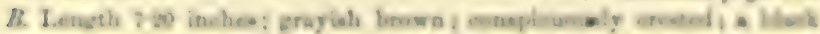

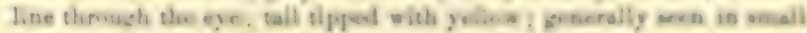

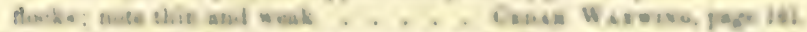

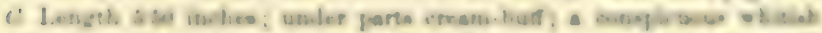

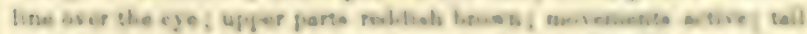

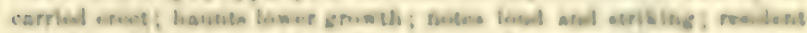

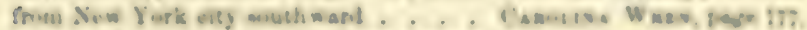

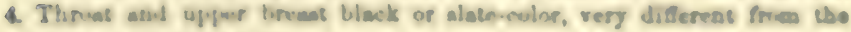
while or chenterus belly.

4. Throes bleck.

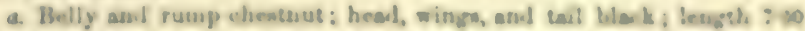

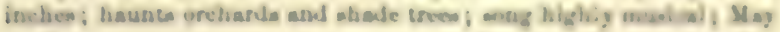
so sope. . . . . . . . Oncmane Umoun pare 12.

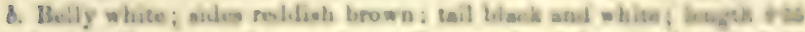

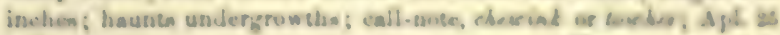
to thes. . . . . . . . . . . Tesenses pege val.

A. Throat alato-eolor.

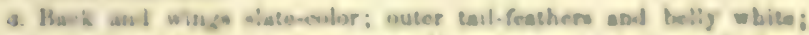

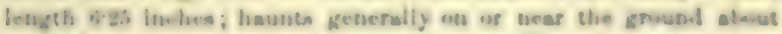

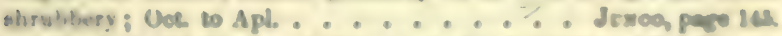

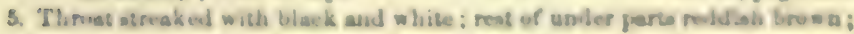

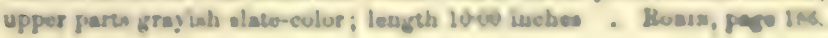




\section{OUR COMMON BIRDS.}

\section{THE WATER BIRDS.}

\section{DIVING BIRDS. (ORDER PYGOPODES.)}

\section{Grebes。 (FAMILy Podicipid A6.)}

THE study of water birds requires special advantages and equipments, among which are a suitable location, much time, and a gun. Our coasts and shores are becoming so popular as "resorts" that many of the former haunts of waterfowl are now thickly populatel, and the birds are comparatively rare. Furthermore, the larger number of our water birds nest in the far North and winter in the South, visiting the Middle States only while on their migrations. It is evident, therefore, that if we would become familiar with these birds, we must devote ourselves especially to their pursuit.

There are, however, some species, notably those which frequent bodies of fresh water and nest in this latitude, - Fied-billed Grobe, which deserve to be ranked among our Podilymbus podicepw. commoner birls. Of these, one of the Plate II. best known, by name at least, is the Pied-billed Grebe, whose aquatic powers have given it the expressive title of Hell-diver.

Under favorable conditions this little Grebe may breed anywhere from the Argentine Republic to British America, but in the Middle States it occurs chiefly as a spring and fall migrant. When nesting, a quiet, reedy pond or lake is chosen for a home, the nest 1 eing made on a pile of decaying regetation. The eggs, four to eight in number, are dull white, more or less stainell by the nesting material, which the parent bird rarely fails to place over 


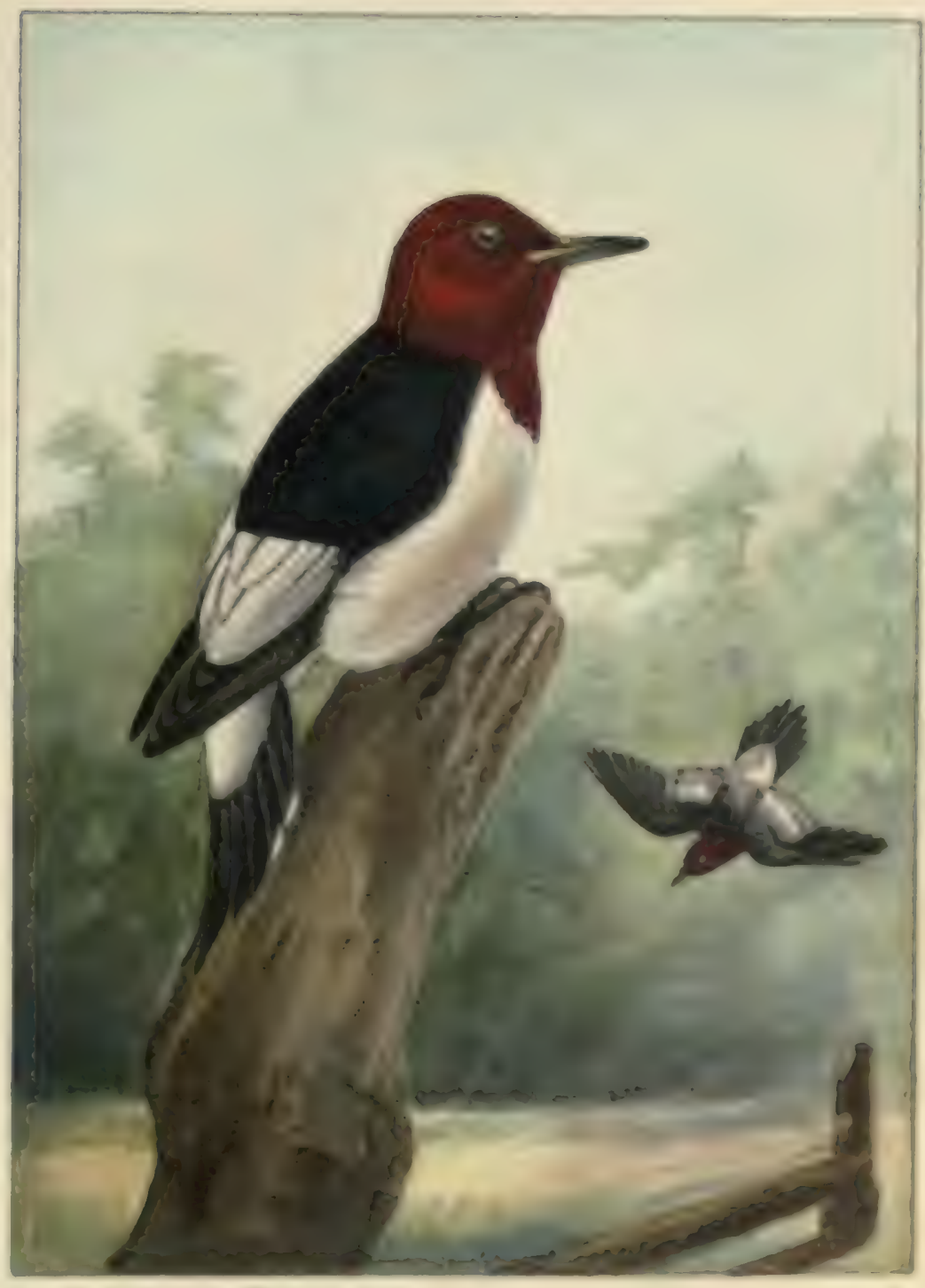

Puts XXV.

PAar IIR.

\section{RED-HRADED WOODPWCKRA}

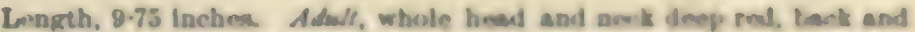

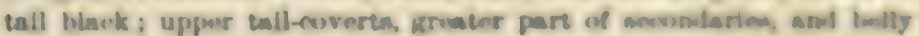

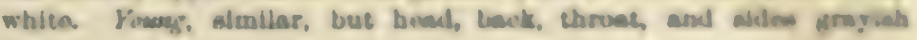
black. 
. 
thens when learing the nest. The young aro hom corems with down and ean swim wo lirth. The Tiej-balled Grebe is one of our aum ajuatie links. When pronsued,

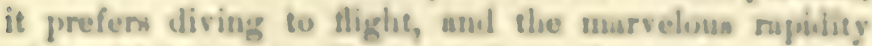
with which it can dinappenor from the nurface of she water, to reappear in a quite unexpereteal place, jumbifien its reliasee on its own nutatorial powen. It cas owim under water with only its bill expremen, whea it becomes practscally invisible.

When on land (irebes prugreas surkwanlly. They van, it is acail, stand erect on their toen, but, when resting. support themselves on the whole lemgth of the fout or tansus (nee Fig. S, the (ireat Auk).

On the wing Gretes resemble suall Duroks, lut their pointed bill and their feet stretched out behisd tho rudi. mentary tail will serve to distimguish them.

\section{Loosa (Faxily Crusatomd $x$ )}

The Loon, like its small relative the Grebe, is known to aluowet every one ly mme, hut only thuse who have Loon, visitel its summer hants among the Erinusser imbor. Nurthern lakes and heard its wild call Plase III. can lie anil to know it. Nuttull writes of its cry as "the and and wolfinh eall of the solitary Loon, which, like a dismal erho, seems slowly to invale the enr, and, rising as it procese la, dies away in the air." It "may he hearl sometimes fur two or three miles, when the lind itself is invisible, or reduced almost to a sperk in the distance." The Iamon is as nquatie in haloita sas the Grelve, but is much stronger on the wing. It mignutes by day, and probably also ly night, and we may sometimes see it passing over-a large, ducklike linl-in March and Octolver.

When on laxd, it is nearly helpione, progrewing awls- 
wardly by the use of feet, wings, and bill. For this reason it nests near the water's edge, often where it can slide from the eggs directly into its true element. The nest is a slight depression in the earth, in which are laid two elliptical eggs, in color olive-brown, slightly spotted with blackish.

LONG-WINGED SWIMMERS. (ORDER LONGIPENNES.)

Gulls and Terns. (Family Larida.)

No birds are more widely distributed than the Gulls and Terns. Some species are pelagic, visiting the land

Herring Gull, only at long intervals and when nestLarus argentatus ing; others live along the coast, and smithronianus. several species resort to inland waters. Plate IV.

About one hundred species are known, fifty being Gulls and fifty Terns. The former are, as a rule, larger, stouter birds than the latter, and, generally speaking, are more maritime. The commonest of the ten species found in the Eastern States is the Herring Gull. It nests from Maine northward, and is found southward along our coast from Oetober 1 to April. This is the Gull we see in such numbers in our bays and harbors, flying gracefully and apparently aimlessly about, but in reality ever keeping its bright black eyes fixed on the water in search of some floating morsel, which it deftly picks from the surface. It frequently follows vessels, hanging over the stern day after day, and deserting its post only to feed on scraps thrown overboard from the galley. There are said to be reliable records of these birds following the same vessel from the Irish coast to New York Harbor.

Gulls do excellent service in devouring much refuse that would otherwise be cast ashore to decay ; but, useful 


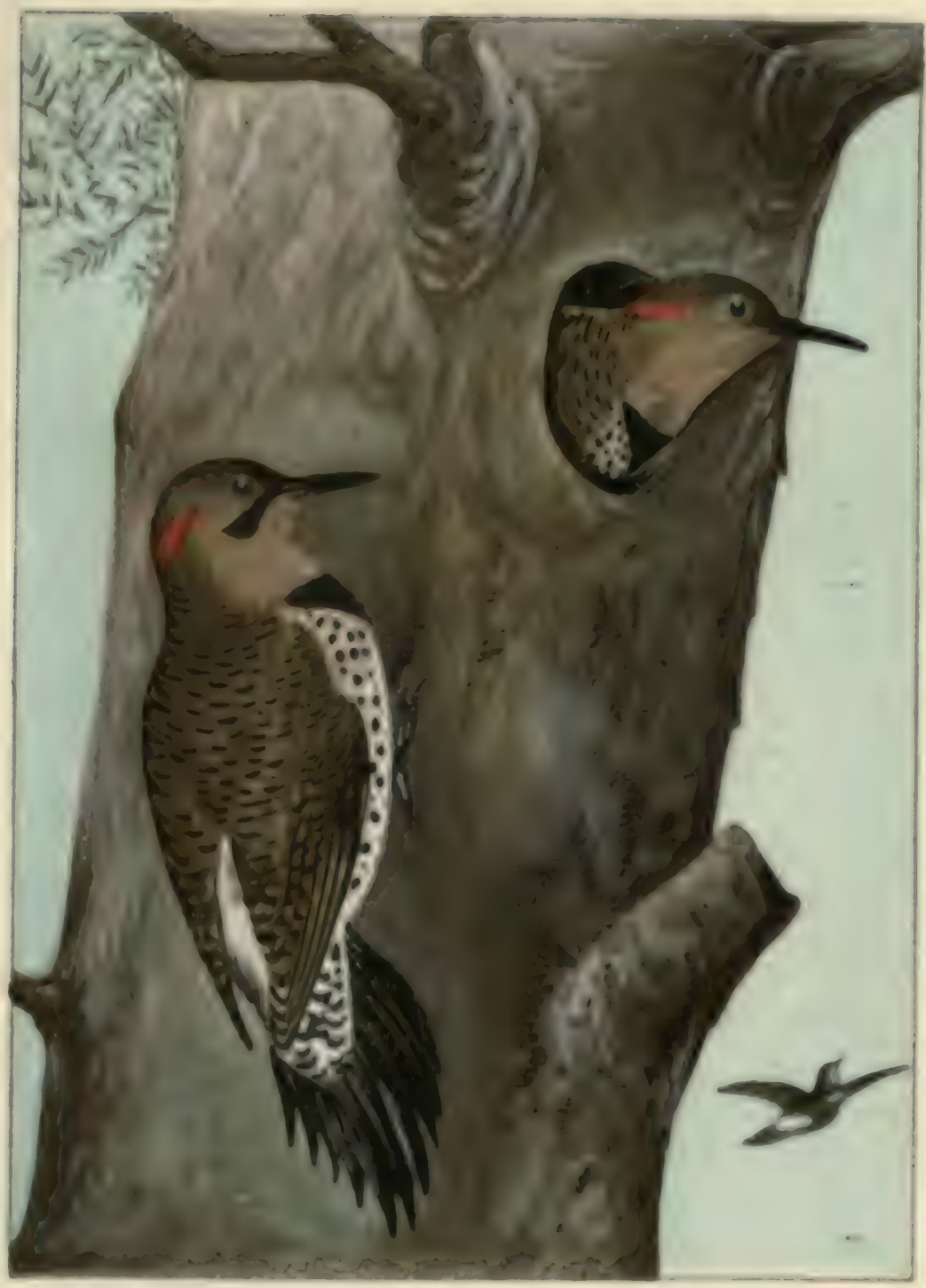

Prate IXVL.

Page 118.

\section{FITKER.}

Length, $18-00$ inchea Mabe, erown Eray, napa scarlet, hank tinownlah

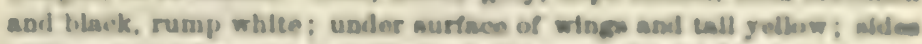

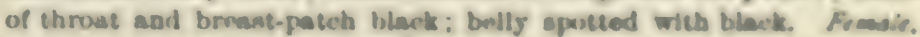
similar, but no black on abdes of throat. 

as they are as senvengen, I feel that their place in Ninture is to animate the harren wastes of the sea. How, when at sea, the pressence of a single Gull changen the whole aspect of Nature! The great expranie of water, which hefore was oppressire in its Ireary lifelessines, is trannformed by the white-winged Gulls inte a scene of rave heauty. Every voyager, be he naturalist or not, adminem their grace of form and motion. They seem born of the waves, and as much a part of the ocean as the foany whitecaps themeelres.

The beautiful Terns or Sea Swallows are even more graceful than the (inulls. They are slenterer lirks, lighter

common Ien, and more active on the wing, with long, sternas hirsmb. forked tails and pointed bills. They Plate $\mathrm{X}$. arrive from the South in May and romain until September, nesting in colonies.

Terns are littoral rather than pelagie, seldom being found far from the shore. Like the Gulla, they seem so in harmony with their surroundings that no coast view is perfect from which the Terns are missing. They ald the requivite touch of life, and make still more impressive the thunder of the surf dashing over rocks or curling in long, combing waves on the beach.

During recent years these birds have been killed in snch numbers for millinery purposes that on the middle Atlantic const the only survivors exist on three or four uninhahited islets. If one protests against the merciless destruction of these exquisite creatures the excuse is, "Well, what gond are they ?"-an answer betraying sucli an utter lack of appreciation of beauty that explanation seems hopeless. IBnt can we not learn, before it is tos late, that these birls are even more deverving of proteo. tion than the works of art we guard so zealously ? 


\section{TUBE-INOSED SWIMMERS. (ORDER TUBINARES.)}

\section{Petrels. (Family Procellariddes.)}

Petrels, or "Mother Carey's Chickens," are true children of the sea. Their home is the ocean, and they come to land only when nesting. To the Petrels, landsman, therefore, they are strangers,
Plate IV. Plate IV. but to most people who have been to sea they are known as the little, white-rumped swallowlike birds who on tireless wing follow in the wake of the ship day after day, patiently waiting for the food which experience tells them will be thrown overboard.

Two species of Petrels are found off our coasts, Wilson's and Leach's. The former has a yellow area in the webs of the toes and a square tail, while Leach's Petrel has the webs of the toes wholly black and a slightly forked tail. These differences, however, would not be appreciable at a distance. Wilson's Petrel nests in certain islands of the southern hemisphere in February, and later migrates northward, resching our latitude in May and spending the summer, or what in fact is its winter, in the North Atlantic. It is, therefore, probably the Petrel most frequently seen by transatlantic voyagers at this season.

Leach's Petrel nests on our coasts from Maine northward, arriving from the South in May. The nest is made in a burrow in the ground or beneath a rock, and a single white egg is laid. Generally one of the birds spends the day on the nest while its mate is at sea, but at night the incubating bird leaves the nest, its place being taken probably by the one who has been feeding during the day. 


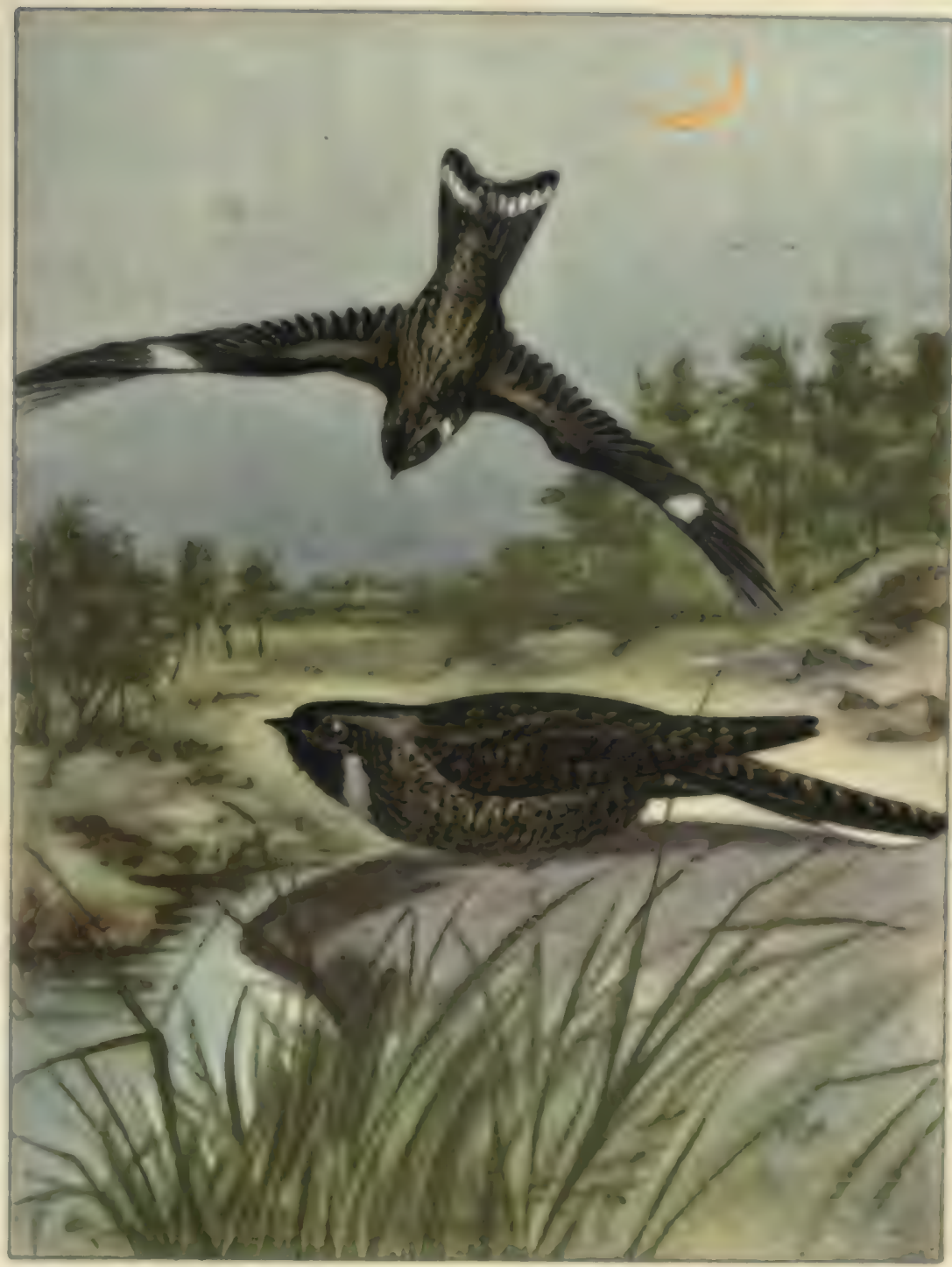

PuAT XXVII.

\section{NTOHTHAWK.}

Pane 128, 118.

Length, inton Inchan Nale, above. blacts. whites, and ruaty: below,

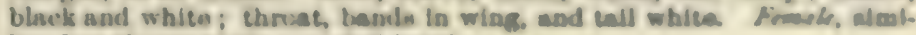
lar, but throat rusty ; no tall-band.

\section{WHIP-100\%-WHA.}

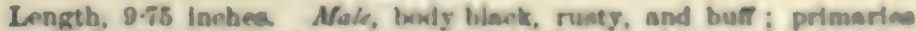

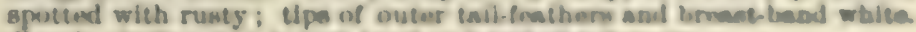
Female, similar, but breast-band and ead of enil rusty. 



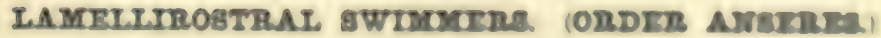

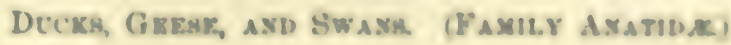

This family contains some two hundred nperien and is represented in all parts of the world. It includes five subfamilies: the Mergatsens (Mergina), or Finh.entirg Ducks; the Pond or River Ducks (Anatina), the Bay or Sea Ducks (Fuligulina); the Geese (Anserina); and the Swans (Cygnina).

Ducks, like all bunted binls, are exceclingly wild, and comparatively few species will come within rench of the student's opera-glase. The group may therefore the reviewed briefly. The Mergansen or Shelldrakes, sum. bering three species, have narrow, sermte bills which enable them to hold the fiah they ponsue and cate-h under water (see Fig. 1s).

The River Ducks have little or no lohe or fap on the hind toe. In this group belong our Malland, Widgewn, Pint til, Blne-winged and Cineen-wingerl IIver Deake, Teals, Black Duck, Wood Duck, and othen. All but the lasit two nest in the North and are found in our latitude only during their apring and fall migrations, or, if the weather le mild, in the winter. The Blacek Duck and Wood Duck neat rarely in the Midclle Stutes.

All theec birds feel in shallow water by "dabliting" or "tipping," terms which will be rovalily undentund by any one who has watcherd domesticated Ducks feeding.

The Bay and Sea Duekn, on the contmiry, are diven, and una desend to the hottom in water mone than one hundred and fifty feet in depth. They aro to te dia. tinguiahel from the River Duckin ly the precenie of a flap or lobe un the hind toe. The cummoner memivers of 
this subfamily are the Redhead, Canvasback, Scaup or Broadbill, Whistler, Bufflehead, Old Squaw, Eider, three species of Scoters or "Coots" and Ruddy Duck. These are all northern-breeding birds who visit the waters of our bays and coasts during their migrations or in the winter.

The bill in both River and Bay Ducks has a series of gutters on either side which serve as strainers. The birds secure a large part of their food-of small mollusks, crustaceans, and seeds of aquatic plants-from the bottom, taking in with it a quantity of mud, which they get rid of by closing the bill and forcing it out through the strainers, the food being retained.

Geese are more terrestrial than Ducks, and, thongh. they feed under water by tipping, often visit the land to procure grass, corn, or cereals, which they readily nip off. The white-faced, black-necked Canada Goose is our only common species. Its long overland journeys, while migrating, render it familiar to many who have seen it only in the air. It migrates northward in March and April and returns in October and November, breeding from the Northern States northward and wintering from New Jersey southward.

The two Swans, Whistling and Trumpeter, found in North America, are generally rare on the Atlantic coast.

\section{HERONS, STORKS, IBISES, ETC. (ORDER HERODIONES.)}

Herons and Bitterns. (FAmily Ardeid

OF the seventy-five known members of this family fourteen inhabit eastern North America. Most of these are Southern in distribution, only six or seven species regularly visiting the Northern States. Their large size 


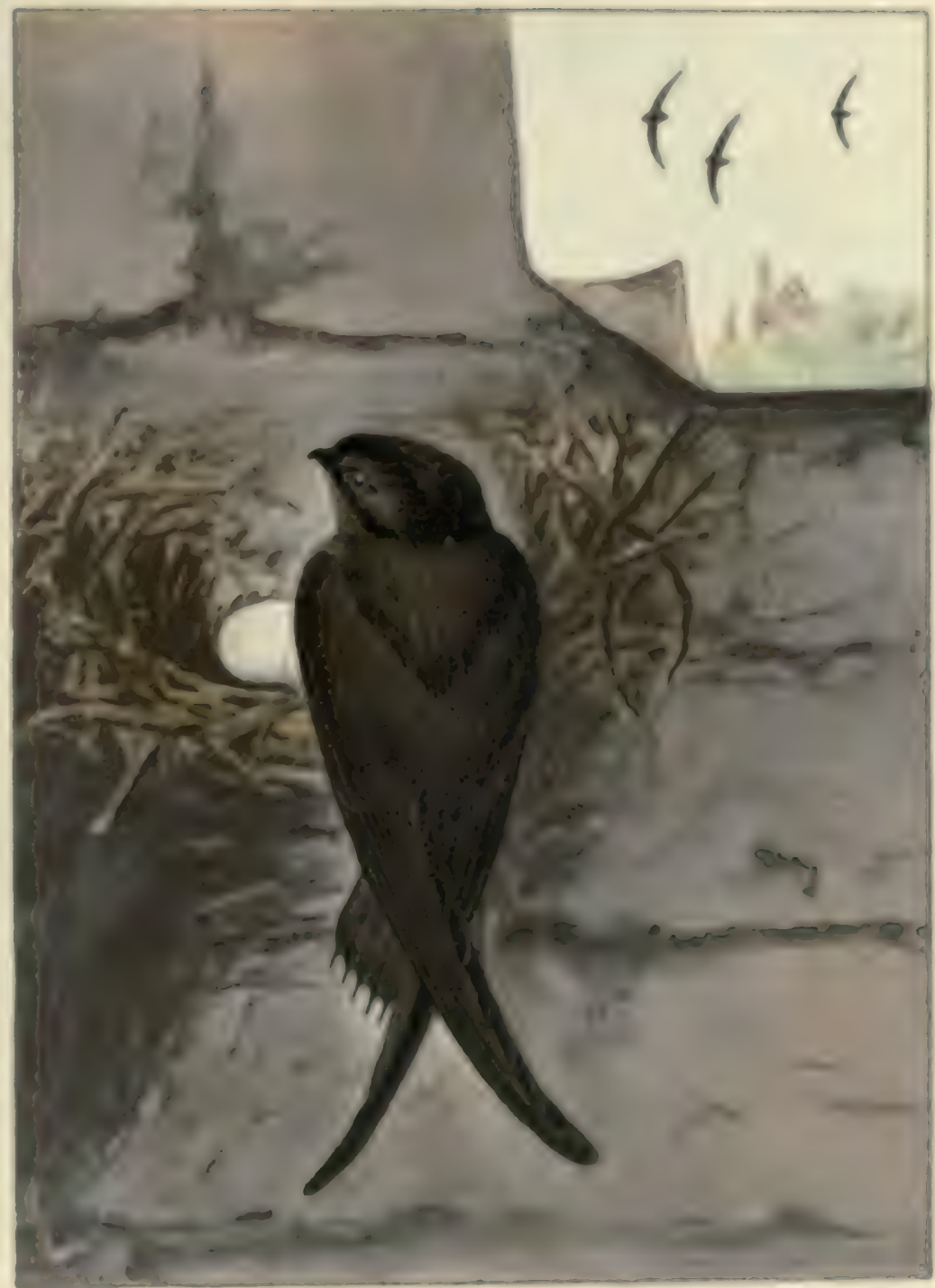

Pтит IXVIII.

Paลe 110.

CEIMNE AWIT.

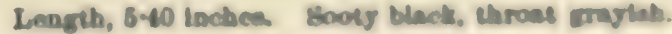



renders Herons conspicuous, and, though worthless as fool, few so-called sportamen can rowist the temptation of shooting at theou when oppurtunity offens. Several of the Southern species, notatily the Snowy Iferun and White Egret, are adoment during the nesting monson with the beautiful "aigrette" plumes which are apprarentsy m nerensury a part of woman's healgear that they will go out of fashion only when the birds go out of exintence. One can not blame the plume huntens, who are grenerally poor men, for killing birls whme plumes are worth moro than their weight in gold-ite Lhare lies in another yuarter. But I have no worls with which to exprosa my condemnation of the mun who kills one of these binds wantonly.

The presence of a stately (ireat IBlue Herun or "Crane" adds an element to the landscape which no Greas Bleo Heron, work of mitn enn equal. Its grace of Iridenheruduse. form and motion, emplaunized by its Plute VI. large size, is a constant delight to the eye; it is a symbol of the will in Nature; one never tires of watching it. What punishment, then, is severe enough for the man who rolus his fellews of so pure a souree of enjoyment? A rifle ball turns this nutsle creature into a useless mass of thesh and fenthens; the loss is irreparable. Still, we have no law to prevent it. Herons are sail to devour lagge numben of munall fish. But is not the lalurer wortlyy of his hire? Are the fiah more valuable than this, one of the grandest of binls ?

The Great Blue Ileron brents througheut North America, but there are now only a few localities in the morthenatern States where it man be found nosting. We usually see it, therefore, as a migmont in April and May. and from August to November.

The little fireen Heron is the smallest, as the Ginent Blue Heron is the largest, of our Herums. Its amall 
size, preference for wooded regions instead of marshes, and habit of nesting alone, not in flocks, like most HerIittle Green Eeron, ons, accounts for its being relatively Ardea virescens. common. It arrives from the South Plate V'. about April 20, and nests early in May. The nest, as is usual in this family, is a rude platform of sticks and is placel in a bush or the lower branch of a tree, often overhanging the water. The eggs number from three to six, and in color are pale greenish blue. The young, although born with a corering of bairlike feathers, are quite helpless and are reared in the nest. Adults have the crown and back dark, glossy green, the neck reddish brown.

The notes of this little Heron are a clear whistle and a harsh squawk, uttered when it is frightened. It then seeks refuge by alighting in a distant bush or tree, and with upstretched neck and twitching tail watches the intruter.

Tis Night Heron, or Squawk, doubtless owes its escape from the fate of most Herons to its nocturnal

\section{Black-crowned}

Night Heron, sycticorus: nycticoras, toler. They nest in large colonies, a nevius.

Plate VI. habits. These birds arrice from the South in April and remain until Ocrookery not far from New York city being inhabited by at least one thousand pairs. It is in a low, rooded tract, and the nests are built in the trees at an average height of thirty feet. The eggs number four to six, and in color are pale bluish green.

At night, while feeding, these Herons are doubtless distributed over a wide area. When flying, they often utter a loud squawk, the origin of one of their common names. It is a surprising sound when heard near by at night, and has doultless aroused the curiosity of many persons who live near a line of flight followed by these birds in going to and from their nests. 


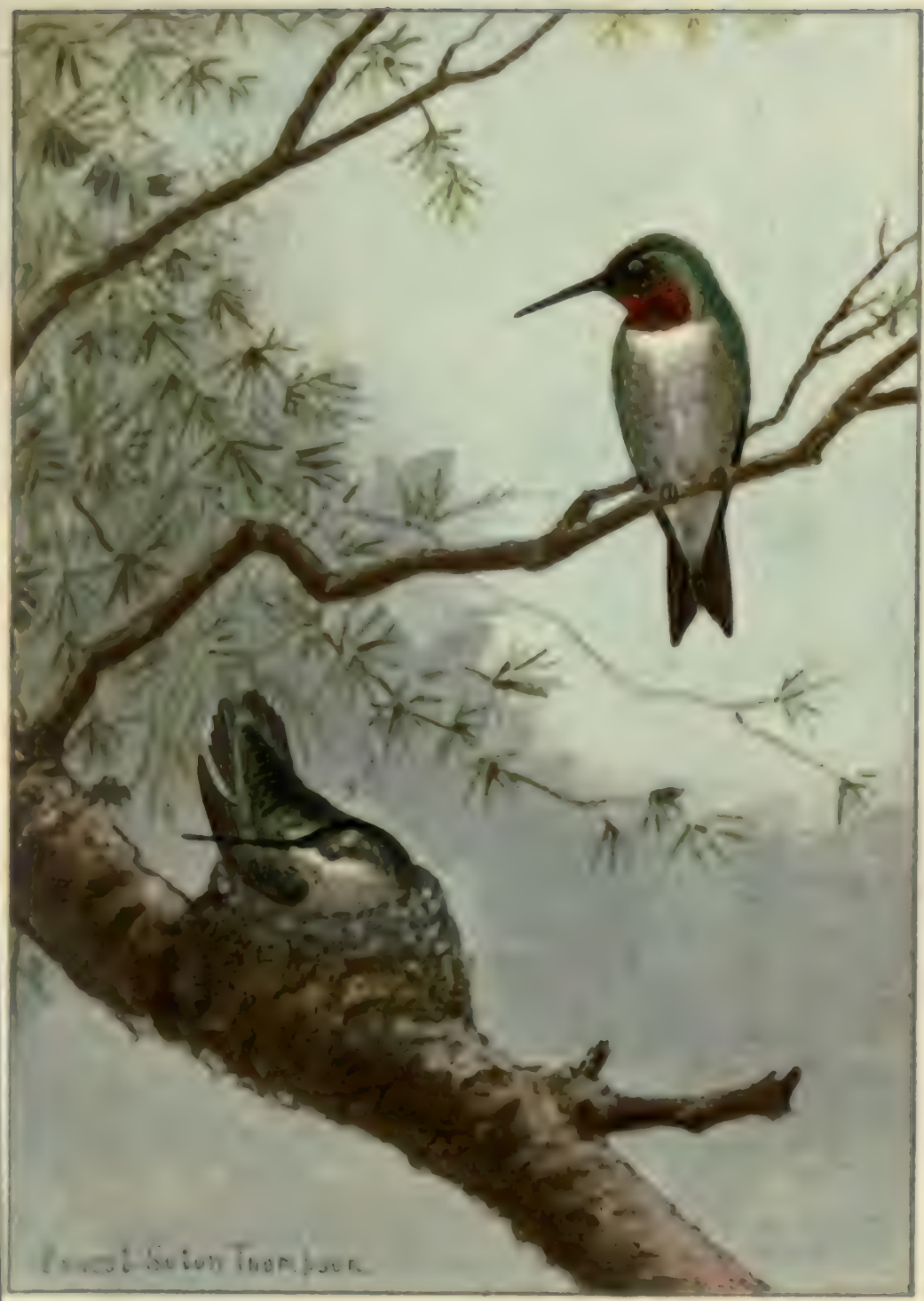

Plate XXIX.

PAOR 180.

REBI-THROATED HUMMINGBIRD.

Length, 3.75 Inches. Adwls male, upper parts metalllo green; throat metallie ruby-red; belly grayish; sides groonish. Adult fomale and young, similar, but throut white. 

The Bittern, or Stake Driver, is a summer resilent of our larger marshes, arriving early in $A$ pril and remaining

Amerioas aitura, until Oetoler. Though by no mean

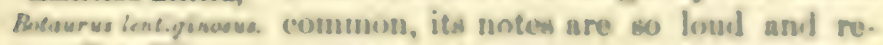
Pate Sit. markable that even a single calling bird is more likely to attract attention than many amaller abundant species. Tnder fuvoralole circunnatances theme notes $\mathrm{m}$ y be heard for at least three fourths of a mile. They are of two kinds. One is descrilnal as the "pump. ing " eall, and is generally written prump.er-luenk, prusnp. er-lunk, piomp-er-lunk, while the other is deceptively like the sound produce l by driving a stake in the mud. Mr. Brudford Torrey, one of the few ornitholugints who hus observed the bird while it was uttering these singular cries, tells us (The Auk, vi, 15s?, p. 1) thut they are attended by vislent, convulsive movements of the heal and neck, which suggest the contortions of a servick penson, but that the birJ's bill is neither immened in water nor plunged in the mud, as has been popularly supposed.

\section{ORANES, RATIS, ETO. (ORDER PALUDICOLA, \\ Ralls asd COots. (Fasily Rallida)}

RaILs are marsh-inhabiting birds, more often heard than seen. They are very reluctant to take wing, and when pursued seek sufety by running or hiding rather than by flying. When flushed, they go but a strort diw: tance, and with dangling legs swon drop back into the grasees.

Of the one hundred and eighty members of this family, fourteen inhabit North Amerien and eight risit the northeastern United States. Only three or four of these, however, are abundant, the muet numerous and 
generally distributed species being our Sora or Carolina Rail, so well known to sportsmen. This bird passes

Sora,

Porzana curolina.

Plate VII.

us in the spring in April and nests from Massachusetts northward. It returns in August and lingers in our wild-rice marshes until October. During the nesting season it lias two calls-a whistled, ker-wee, and a high, rolling whinny. In the fall it utters a luk or peep when disturbed.

There is no sexual difference in color in this species, but birds of the year lack the black about the base of the bill and on the throat, and have the breast washed with cinnamon.

Our other species of Rail are the King, Yellow, and Little Black Rail, all of which are rare; the Virginia Rail,

Clapper Rail, Rallus crepitans.

Plate VIII. which is more common, and the Clapper Rail or Marsh Hen, an abundant species in some of the salt marshes along our coasts from Long Island southward. It is a noisy bird with a peculiar cackling call which it utters in a way that suggests the sound produced by some automatic toys.

Its nest is made of dried grasses, the surrounding marsh grass being slightly arched over it. Eight to twelve buffy, speckled eggs are laid, a number which, in connection with the abundance of the lird, has led to the persistent robbing of its nests by men who sell the eggs for food. As a result of this practice the birds have greatly decreased in numbers during recent years.

The Coot, Mud-hen, or Crow-duck differs from the Rails in having lobed toes (see Fig. 12) and in being

American Coot, Fulica americana.

Plate VIII. more aquatic. In fact, it is more like a Duck in habits than like a Rail, but its pointed, white-tipped bill will prevent its being mistaken for one. 
Erment Seton Thampen
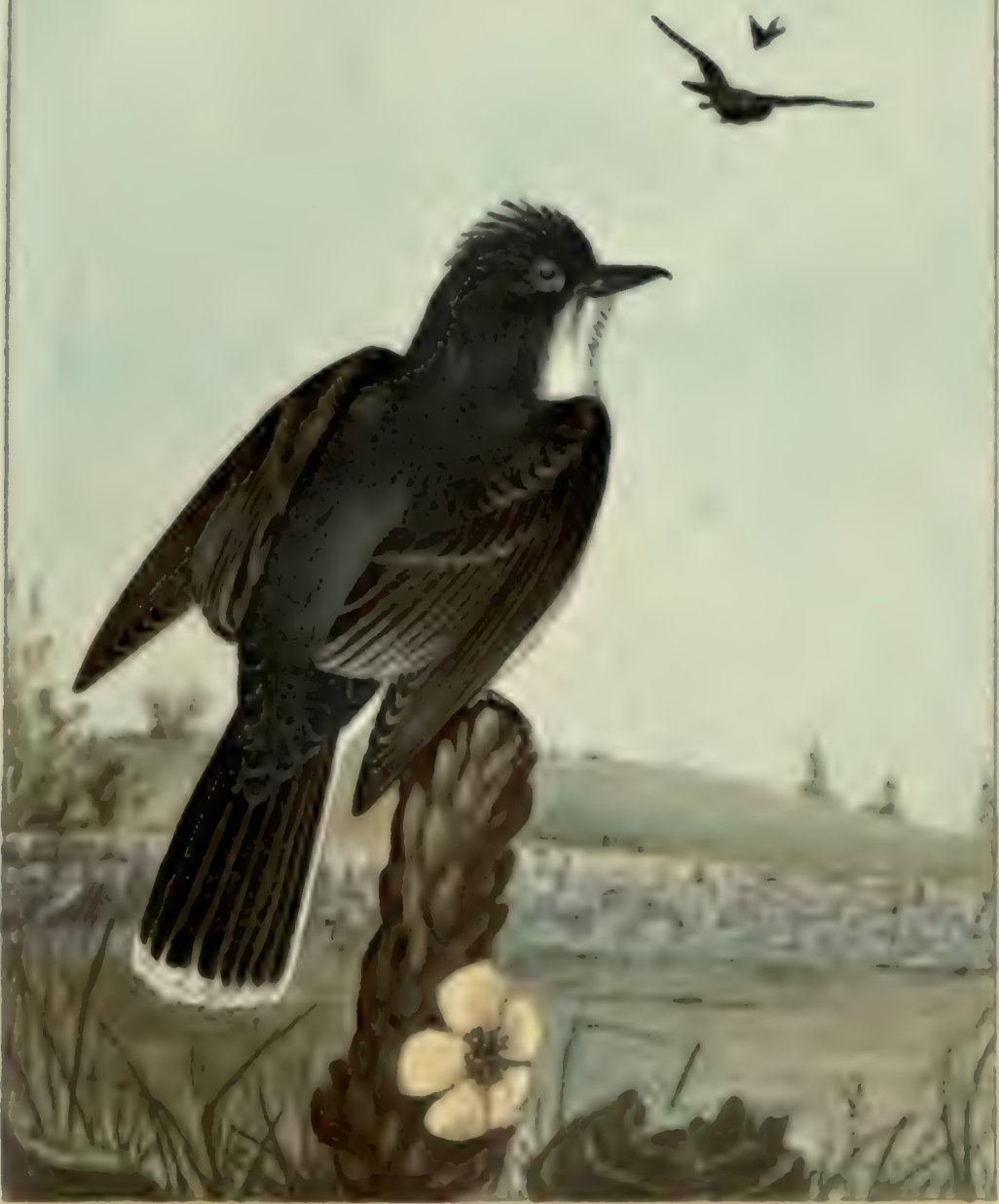

PTATE XXX.

KINABIRD.

Longth, $8 \cdot 50$ inches. Upper parts grayleh black; tip of tall and under parts whlte: an orange-red erown-pateh. Youss, similar, but without ornngo-red in crown. 

It rarely breeds on the Atlantic coast, but is sometimes common on our marsh-bordered streams in the fall.

\section{SHORE BIRDS. (ORDER LIMICOLAE.)}

\section{Sitpes asd Sandpipers. (Family Scolopacide.)}

TuE successful pursuit of shore birds on our coaste requires a specinl knowledge of their notes and habits. Thirty of the one hundred known species visit us annually, but of this number only two or three nest, most of the others migrating in May to their breeding grounds in the far North. The return migration takes place during July, August, and September, but with some exceptions these birds are seen only by those who hunt them sys. tematically with decoys.

Only these exceptions and our summer resident species will be mentioned here. Commonest among the latter is the Woodeock, a bird so unlike other

Woodoock,

Ihiluhelu minur. Snipe in his choice of haunts that he seems quite out of place in this family. Nor is he, strictly speaking, a summer resident, for there are only three months in the year when the Woodeock is not with us. He comes in March as soon as the frostbound earth will permit him to probe for his diet of worms, and he remains until some December freeze drives him eouthward.

Low, wet woods, where skunk cabbage and hellebore thrive, or bush-grown, springy runs, are the Woodcoek"s early haunts. In August, while molting, he often visits cornfields in the bottom lands, and in the fall wooded hillsides are his resorts. But, wherever he is, the Woodcock leaves his mark in the form of "borings"-little holes which dot the earth in clusters, and show where the bird 
has probed for earthworms with his long, sensitive bill, the upper mandible of which, as Mr. Gordon Trumbull has discovered, the bird can use as a finger.

The Woodcock's nest is made of driel leaves, and the four large, pear-shaped eggs are buff, spotted with shades of reddish brown. The young are born covered with rich chestnut and buff down, and can run as soon as dry.

As a songster the Woodcock is unique among our summer birds. Orlinarily sedate and dignified, even pompous in his demeanor, in the spring he falls a victim to the passion which is accountable for so many strange enstoms in the hird world.

If some April evening you visit the Woodcock's haunts at sunset, you may hear a loud, nasal note repeated at short intervals-peent, peent. It resembles the call of a Nighthawk, but is the Woodcock sounding the first notes of his love song. He is on the ground, and as you listen, the call ceases and the bird springs from the ground to mount skyward on whistling wings. $\mathrm{He}$ may rise three hundred feet, then, after a second's pause, one hears a twittering whistle and the bird shoots down steep inclines earthward. Unless disturbed, he will probably return to near the spot from which he started and at once resume his peenting. This, with the twittering note, is vocal; the whistling sound, heard as the bird rises, is produced by the rapid passage of air through its stiffened primaries.

Our only other common summer resident Snipe is the Spotted Sandpiper. It frequents the shores of lakes, spotted sandpiper, ponds, and rivers, and is also found Actitis mucularia. near the sea, but wherever seen may be

Plate XI. known by its singular tipping, tetering motion, which has given it the names of Tip-up and Teter Snipe. It is also called Peet-weet, from its sharp 


$$
R
$$



call, mpidly repented as it flies over the water. After gaining healway it sails for some distance, when its widestretched wings bhow a white bar or band.

The Spotted San.lpiper arrives from the South late in April and remains until Oetober. It nests in the latter half of May, laying four pear-shaped eggs, in color white or buff, thickly spottel and specklel with chocolate, ehiefly at the larger end. The young, like thuse of all Snipe, are born with a covering of downy feathers, and can run as soon as dry. The egg is, therefore, large in proportion to the size of the bird, and measures 1.25 by .93 inches. (See Fig. 24a.)

Enlike the two preceding birds, Wilson's or the English Snipe is not a summer resident in the Middle

Willoon's Baipe, Gallinatge deliculas.

Pluate IX. States, but as a rule nests from northem New England northward, though there are records of its breeling as far south as Connecticut and Pennsylrania. It migrates northward in March and April, and the return journey occurs during Septemher and Octoher. It is not a true shore birl, but frequents fresh-water marshes and meadows, and in rainy April wenther, when the lowlands become more or less floode l, it may be found in places where few persons would think of looking for Snipe.

Like the Wondcock, Wilson's Snipe proles the mud for food, and when on the ground among the grasses its colors and pattern of coloration so closely resemble its surroundings that it is almost invisible.

When flushel, it utters a startled scaip, and darts quickly into the air, flying at first in so erratic a manner that it has become farnous among sportsmen as a difticnlt mark.

Like the Nighthawk, Wilson's Snipe sometimes dires enrthward from high in the air, making as he falls a sound which Minot compares to that produced by throw. 
ing a nail held crosswise in the hand, though it is louder and more full. This performance is generally restricted to late evening and early morning during the spring, but is occasionally practiced in the fall.

Most of our transient visitant Snipe are true shore birds. Many of them are classed as game birds, and have Semipalmatod now become so uncommon that, as

sandpiper, before remarked, it requires a special Ereunetes pusillus. knowledge of their ways in order to Plate $\mathbf{X}$.

find them. But there are some species too small to be worthy the sportsman's attention, and they are often numerous on our beaches. They are generally known as Peeps or Ox-eyes, but in books are termed Semipalmated Sandpipers-active little fellows, with black, gray and rusty backs and white under parts, who run along the shore, feeding on the small forms of life cast up by the waves. They are sociable birds, and even when feeding the members of a flock keep together, while when flying they move almost as one bird.

These Sandpipers visit us in May, when journeying to their summer homes within the Arctic Circle, and return in July, to linger on our shores until October. Their call-note is a cheery, peeping twitter, which probably suggested one of their common names.

\section{Plovers. (Family Charadrim as.)}

Most Plovers differ from Snipe in possessing three instead of four toes, and in having the seales on the tarsi rounded, not square or transverse. Their bill is shorter and stouter than that of Snipe, and they do not probe for food, but pick it up from the surface.

Although several species visit dry fields and uplands, they are ranked as shore birds or bay birds, and, as with Snipe, the species large enough to be ranked as game 


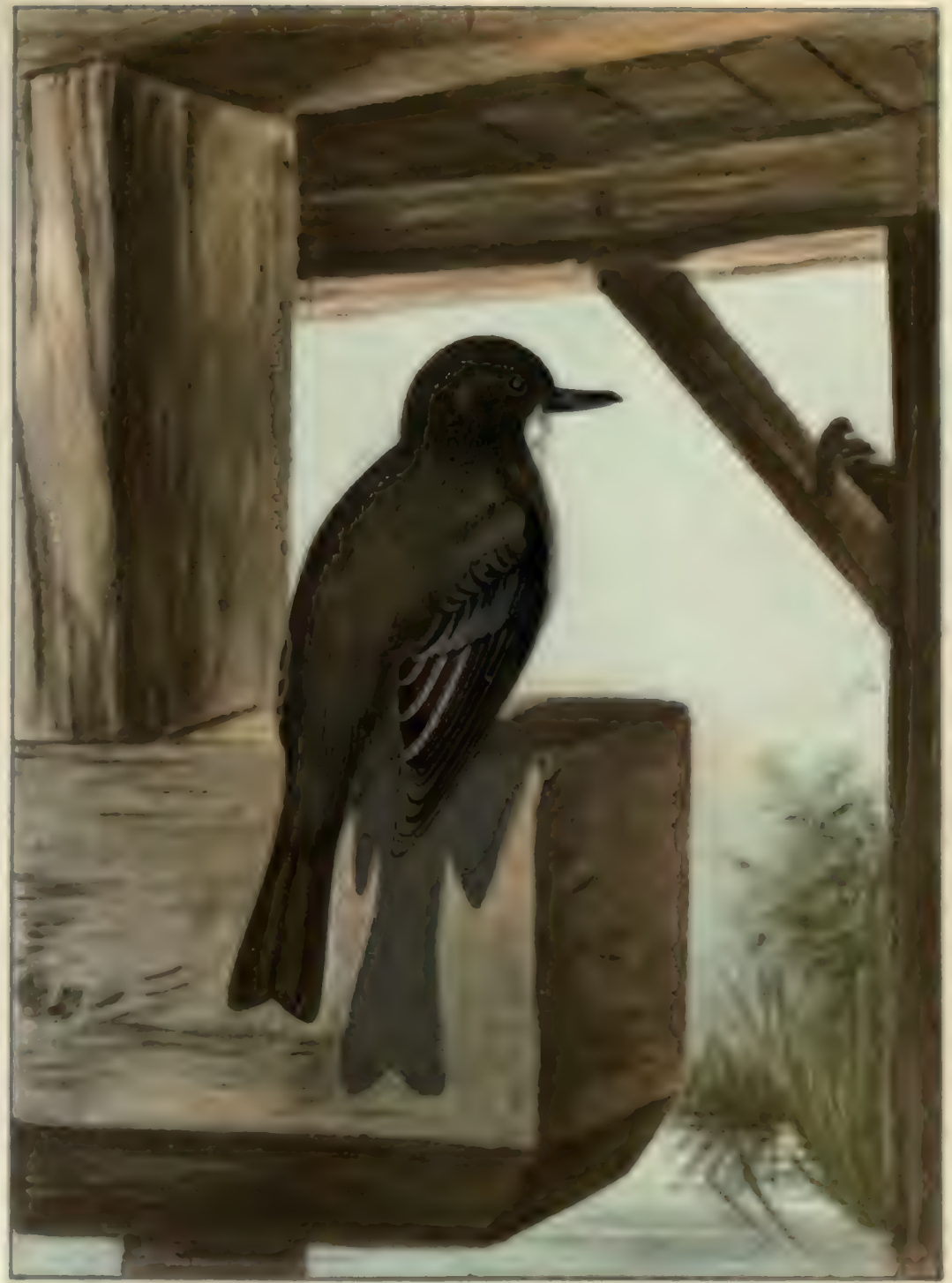

PIATE XXXII.

Page 124.

\section{PHOBE.}

Longth, 700 Inches. Back dusky ollve; orown blackiah; under parts white tinged with yellow; onter margin of outer tall-fenthers whitish; bill black. 

have become comparatively rare. Of the one hundred known species, six visit eastern North America-the Black-breasted, Golden, Piping, Wilson's, Semipalmated, and Killdeer Plovers. Only the last two of these are common enongh to deserve mention here.

Kindeer,

The Killdeer, with the exception of . Fyialitis rocifera. the Piping Plover, is the only bird of I'late XI. this family that nests with us. It is irregularly distributed in the northeastern States, but its noisy call, kildee, killee, and striking markings render it a conspicuous bird even where it is uncommon. It frequents uplands and lowlands, fields and shores, but prefers the vicinity of water. Its nest of grasses is made on the ground, and its four eggs are whitish, spotted and scrawled with chestnut, chiefly at the larger end.

The Semipalmated or Ring-necked Plover looks like a miniature of the Killdeer, but, in addition to other difsemipalmated Plover, ferences, has only one band on the Epialitis breast. The male has the upper parts acmipalmala. brownish gray, the under parts, nape, Plate $\mathrm{X}$. and forehead white, while the breastband, crown, and cheeks are black. In the female these black areas are brownish gray. This Plover visits our shores and beaches during its northward migration in May and southward migration in August and September. Thanks to its small size, it is not hunted as game, and for this reason is almost as common as the little Peeps or Ox-eyes, with which it often associates. Its call is a simple but exceedingly sweet and plaintive two-noted whistle. 


\section{THE LAND BIRDS.}

\section{GAITENACEOUS BIRDS. (ORDER GAIITNA2.)}

Bob-whites, Grodse, etc. (Family Tetraonid ze.)

THIs is the family of the game birds-the aristocrats of the bird world. They are protectively colored birds, their rich brown, buff, and black plumage harmonizing with their surroundings. Relying on their inconspicuousness, they avoid danger by hiding rather than by flight, taking wing only as a final resort. Then, with a startling whir-r-r, they spring into the air, their short, strong wings enabling them to reach their greatest speed within a short distance of the starting point.

One of the best-known members of this distinguished family is our familiar Bob-white, the Quail of the North

Bob-white, and Partridge of the South. The fact Colinus virginiamus. is, he is neither a true Quail nor Partridge, and those who claim that but one of these names is correct may compromise on "Bobwhite."

The Bob-white inhabits the eastern United States, and wherever found is resident throughout the year. The sexes are much alike in color, the only important difference being in the throat and the line over the eye, which are white in the male and buff in the female.

No bird better illustrates the peculiar potency of bird song, and the hopelessness of attempting to express its charm. If I should describe Bob-white's call to à person who had never heard it, as two ringing notes, do you suppose he would have the faintest conception of what 


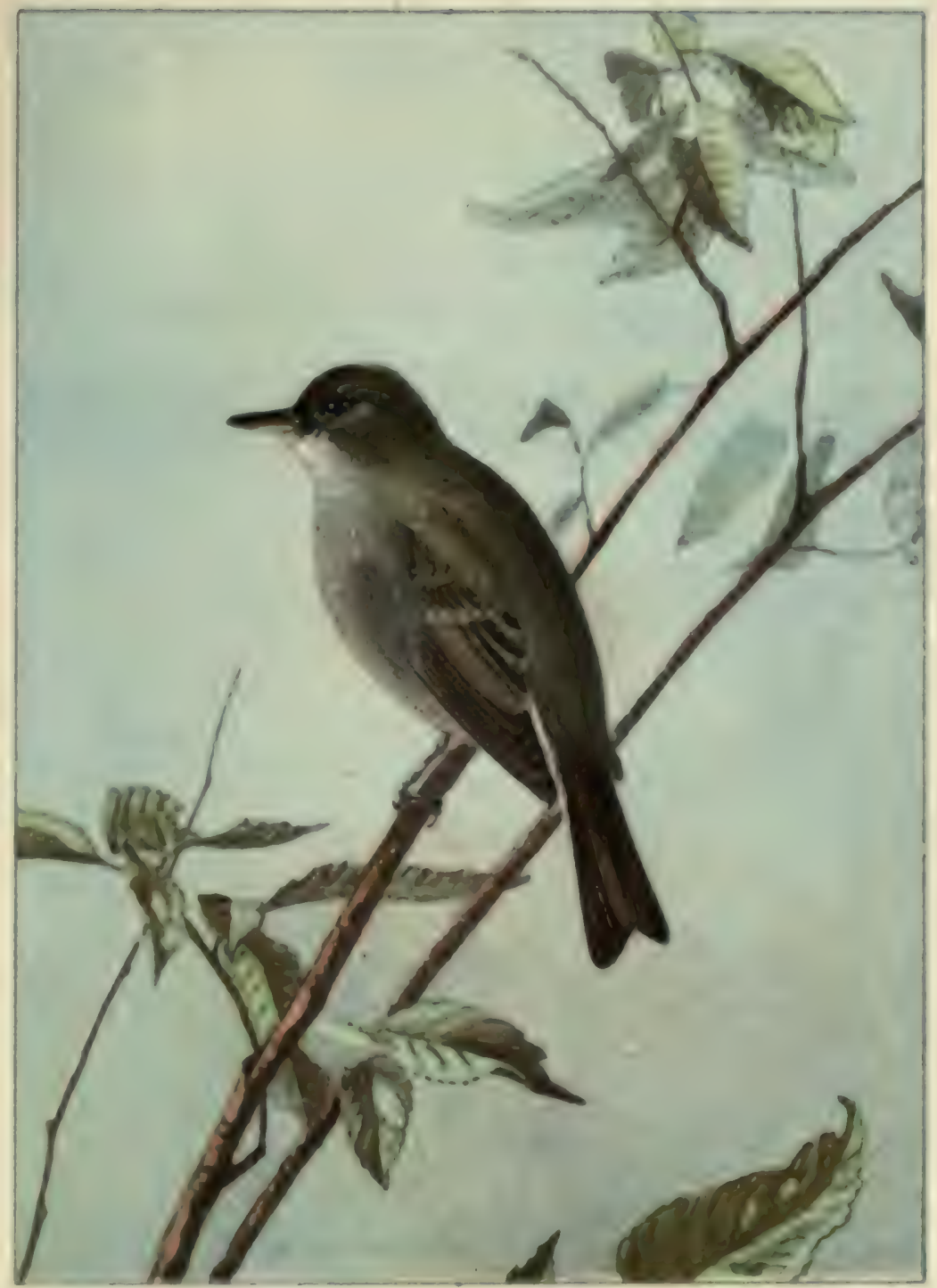

Phate XXXIII.

PAQE 126.

WOOD PEWER

Length, 6.50 Inches. Opper parts duoky ollve-green; under parts whitlah, washed with dusky; lower mandible yellowlah. 

they mean to those who love them i The promise of Spring, its fultillment in summer, is clearly told in Bobwhite's greeting. Then, in the sutumn, when the mern. bers of a scattered bevy are signaling each other, their sweet vhìre are you \& where are you ? is equally associated with the season.

The Bob-white nests about May 20, laying from ten to eighteen white eggrs in a nest on the ground.

The Ruffed Grouse, or Partridge of the North and Pheasant of the South, is properly a true Grouse, and

Rafled Groase,

Bonsea umbelluse. Plate XIL. can not be correctly called either Partridge or Pheasant. He is a more northern bird than the Bob-white, being found south of Virginia only in the Alleghanies. Requiring large tracts of woodland for his haunts, he is less generslly distributed and not so common as his plump relative.

I always associate the Grouse with the astounding roar of wings made by the bird as he springs from the ground at my feet and sails away through the forest. I watch him at first with dazed surprise, then with a keen sense of pleasure in the meeting. One need not be a sportsman to appreciate the gaminess of the Grouse.

To find a hen Grouse with young is a memorable experience. While the parent is giving us a lesson in mother-love and bird intellizence, her downy chicks are teaching us facts in protective coloration and heredity. How the old one limps and flutters! She can banely drag herself along the ground. But while we are watching her, what has become of the ten or a dozen little yellow balls we almost stepped on? Not a feather do we see, until, poking about in the leaves, we find one little chap hiding bere and another equatting there, all perfectly still, and so like the leaves in color as to be nearly invisible. 
The drumming of the Grouse, as described by Mr. Thompson, begins "with the measured thump of the big drum, then gradually changes and dies away in the rumble of the kettle-drum. It may be briefly represented thus: Thump - thump - thump - thump, thump; thump, thump-rup rup rup rup, $r-r-r-r-r-r-r-r-r$. The sound is produced by the male bird beating the air with his wings as he stands firmly braced on some favorite low perch."

The Ruffed Grouse makes its leaf-lined nest usually at the base of a tree or stump, and the eight to fourteen buff eggs are laid early in May.

\section{PIGEONS AND DOVES. (ORDER COLUMBA.)}

Pigeons and Doves. (Family Columbida.)

The three hundred species belonging in this order are distributed throughout most parts of the world, but only two of them are found in the northeastern States. One of these, however, the Wild Pigeon, is now so rare that its occurrence is worthy of note. Less than fifty years ago it was exceedingly abundant, but its sociable habits of nesting and flying in enormous flocks made it easy prey for the market hunter, and, with that entire disregard of consequences which seems to characterize man's action when his greed is aroused, the birds were pursued so relentlessly that they have been practically exterminated.

The Mourning or Carolina Dove has happily been more fortunate. Nesting in isolated pairs, and not Mourning Dove, gathering in very large flocks, it has Zenaiduru macroura. escaped the market hunter.

Plate XIII. This Dove is found throughout the greater part of North America. In the latitude of New York it is a summer resident, arriving in March and 


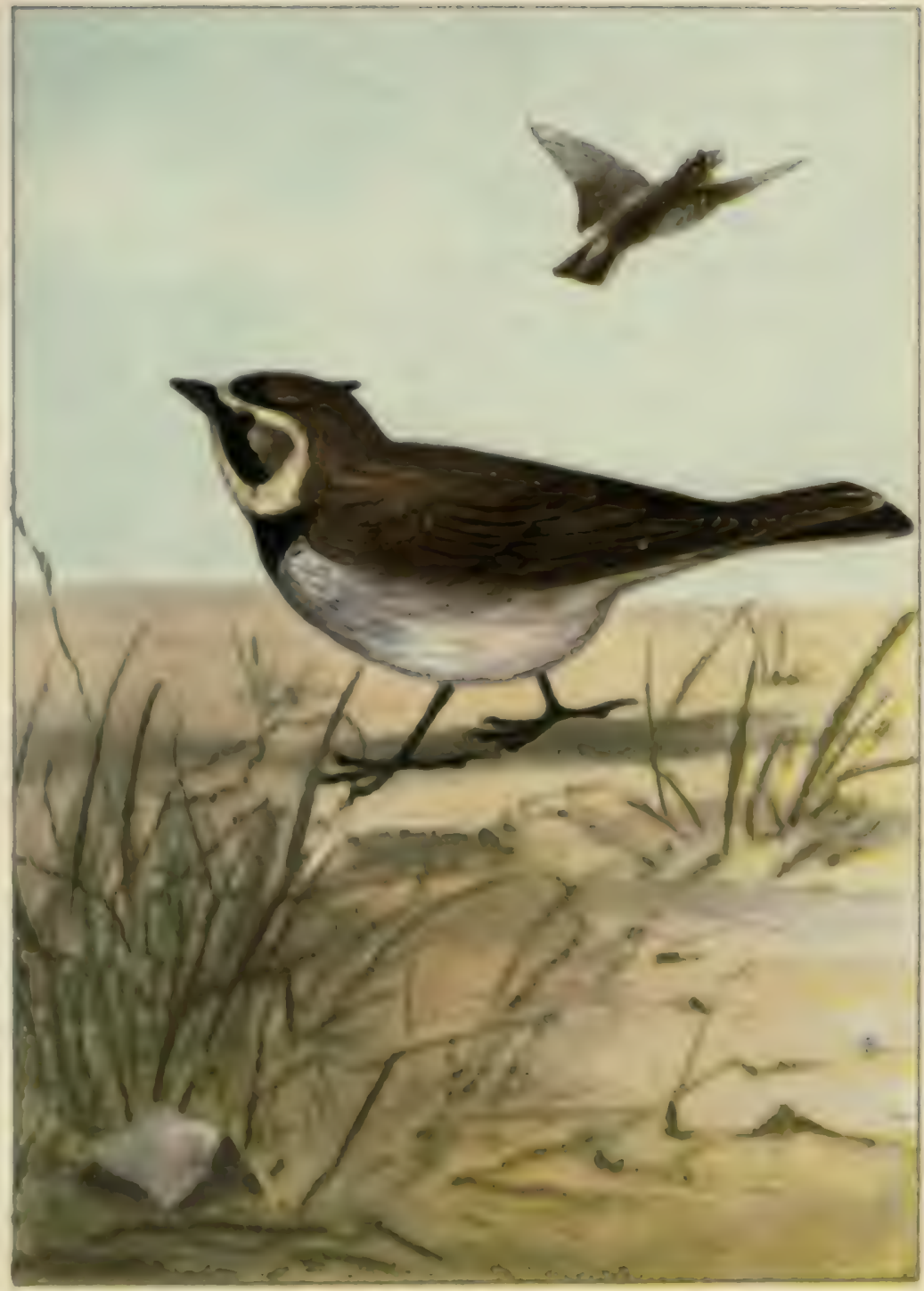

PUATE XXXIV.

Psan 18s

BORNED LABX.

Length, 7.75 Inchea. Upper parts browalab and andy: moat and aldes of crown, aldes of throet, and breast-patub black: forebead. theo over eye, and throat pale yellow: breast duiky, bolly whte, tell bluck, outer feachers mangined with white. 

remaining until November. In A pril we may bear its

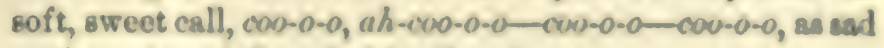
as the voice of the wind in the pines.

Although the birl is as beautiful in appearance an it is graceful in flight, it is a surprisingly poor housekeeper. Its platform neat of a few twigs is about as flimsy as any. thing worthy the name can be, and one wondens how even two eggrs are kept on it long enough to hatch. In the West the nest is placed on the ground; in the East, on the lower branch of a tree.

Like all the members of their family, Doves immense the bill while drinking, and do not withdraw it until the draught is finished. The young are fod on softened food regurgitated from the parent's crop.

\section{BIRDS OF PREY. (ORDER RAPTORTA)}

\section{Ayericas Velteres (Fayily Cithabtid a )}

THERE are but eight Vultures in the western hemisphere, and only two of these, the Black and the Turkey Vulture, are found in the eastern Cnited States. The forner is not often seen north of North Turkey Vultura, Carolina, but the Turkey Vulture, or Turkey Buzzard, as it is more frequent. ly called, comes each summer as far as Princeton, N. J., and occasionally strays farther north.

The Turkey Buzzard is one of Nature's scavengers, and, as such, is one of the few birds whose services to mankind are thoroughly appreciated. There are othen of equal or even greater value who daily earn their right to the good will which we stupidly and persistently refuse to grant them; but of the Turkey Buzzard's aseintance we have frequent convincing proof, and the decree has gone forth that injury to this bird is punishable by fine. 
No other birds are so well protected; and as a result Turkey Buzzardsand Black Vultures walk about the streets of some of our Southern cities with the tameness of domestic fowls. If we should similarly encourage our insectivorous birds, who can predict the benefits which might accrue?

Hawks, Falcons, and Eagles. (Family Falconid

To this family belong the diurnal birds of prey, which number some three liundred and fifty species, and are distributed throughout the world. They are birds of strong flight, and capture their prey on the wing by striking it with their sharp, curved claws, the most deadly weapons to be found in any bird's armament. The bill is short, stout, and hooked, and is used to tear the prey while it is beld by the feet.

The voices of Hawks are in keeping with their dispositions, and, while their lives typify all that is fierce and cruel, no birds are more often wrongly accused and falsely persecuted than our birds of prey. To kill one is regarded as an act of special merit; to spare one seems to place a premium on crime. Still, these birds are among the best friends of the farmer. There are but two of our common species, Cooper's and the Sharp-shinned, who habitually feed on birds and poultry. Our other common species are, without exception, invaluable aids to the agriculturist in preventing the undue increase of the small rodents so destructive to crops.

Any one reading Dr. Fisher's reports on this subject can not fail to be impressed with the array of facts he Bed-shouldared presents in proof of the value of these Hawk, birds. For instance, the Red-shoulButeolinentus. dered Hawk, to which the name Plate XIV.

Chicken or Hen Hawk is often applied, has been found to live largely on small mammals, 


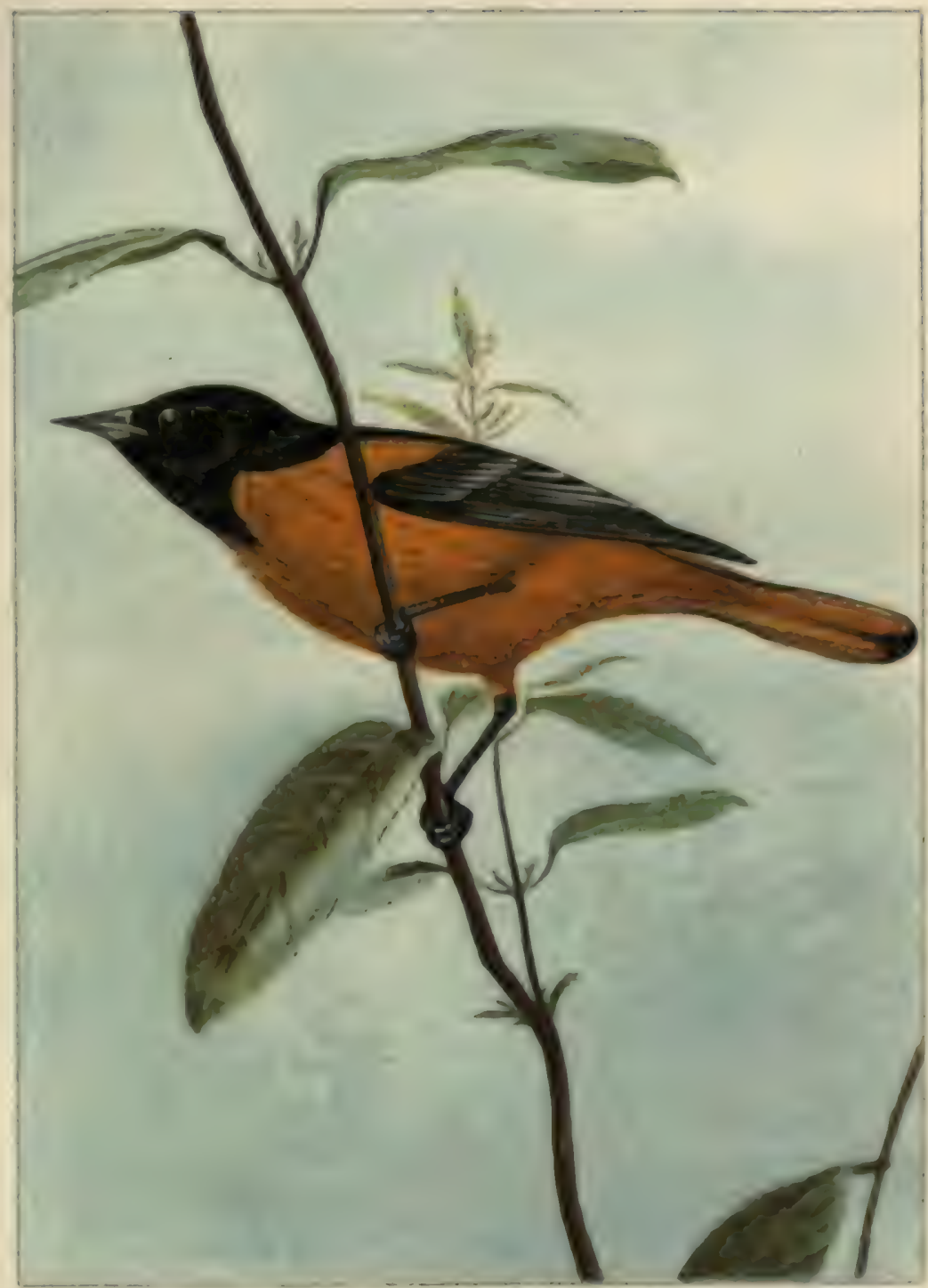

Pute XXIV.

Paos 191.

BALTIMORE ORIOLE

Longth, 7.60 Inehes Male, crown, upper hack, and thronit black: hower back, outer tall-f sathers, breant, and belly Het omage; fono ole, uppor parts mixed black and yellowiah, rump and tall dirty yellow; under parts dusky yellow. 

reptiles, batrachians, and insects. Indeed of 220 stomachs which were examined of this so-called "Chicken" Hawk, only 3 contained remains of poultry 1 Of the rest, 12 contained birds; 102, mice; 40, other mammals; 20 , reptiles; 39 , batruchians; 92 , insects; 16 , spiden; 7 , crawfish; 1 , earthworms ; 2 , offal ; 3 , fish; and 14 were empty." The usefulness of this Hawk is therefore obvious, and in killing it we can readily see that we not only harm ourselves but render an important service to our enemies.

Fortunately, this valuable ally is one of our commonest Hawks, and is with us throughout the year. Its loud scream, kie-you, kie-you, as it suils ahout, high in the air, is a familiar summer sound. The "red" shoulder is in reslity a rich, reddish chestnut on the lesser wing-coverts, and serves to identify the bir 3 in both immature and adult plumige. The Rel-shoulier's nest, like that of most of our IIsw'ks, is constructed of sticks and twigs, with a lining of celar bark, mose, or some other soft material, and is situatel in a tree thirty to sixty feet from the ground. Apparently the same pair of birds return to a loeality year after year, sometimes using the same nest, at others building a new one. The eggs are about as large as those of a hen and in color are dull white, more or less sprinkled, spotted, or blotched with cinnamon-brown or chocolate. They are laid early in April, most of the Hawks being early breeders. The young are born covered with white down, but are helpleas, and are reare 1 in the nest.

The Red-taile.1 Hawk is also known as the Hen Hawk or Chicken Hawk, but has almost as good a record as

- See Fisher, The Hawks and Owls of the United States in their Relation to Agrieuleure: Bulletin Xn. 3. Uivision of Umithologs and Mammalogy, United States Departmont of Agriculture, 1803. 
the Red-shoulder, and is equally deserving of protec. tion. He is larger than the Red-shoulder, whom he resembles in habits, and has a reddish

Red-tailed Hawk, brown tail and a broken black band Buteo borealis.

across the breast when adult. His call is a thin, long-drawn, wheezy whistle, which reminds one of the sound produced by escaping steam.

The Marsh Hawk courses to and fro over field and meadow, like a Gull over the water. He never sails,

Marsh Hawk,

Circus hudsonius.

Plate XV. however, but on firm wing flies easily and gracefully, ever on the watch for prey in the grasses below. He may sometimes mistake birds for mice, but he captures far more of the latter than of the former, and only 7 of the 124 Marsh Hawks whose stomachs were examined by Dr. Fisher had eaten chickens.

The Marsh Hawk is migratory, and in winter is not often found north of southern Connecticut. He nests later than the resident Hawks, and, unlike them, builds his nest of grasses on the ground in the marshes, laying from four to six dull white or bluish white eggs early in May.

The Sparrow Hawk has a perfectly clean record, as far as chickens go, not one of the 320 whose stomachs

Sparrow Fawk,

Falco sparverius.

I'late XVI. were examined by Dr. Fisher, having partaken of poultry, while no less than 215 had eaten insects, and 89 had captured mice. Grasshoppers are the Sparrow Hawk's chief food, and we may often see him hovering over the fields with rapidly moving wings. Then, dropping lightly down on some unsuspected victim below, he returns to the bare limb or stub he uses for a lookout station, uttering an exultant killy - killy — killy as he flies.

The Sparrow is distributed throughout the greater part of North America, but in winter is not found north 


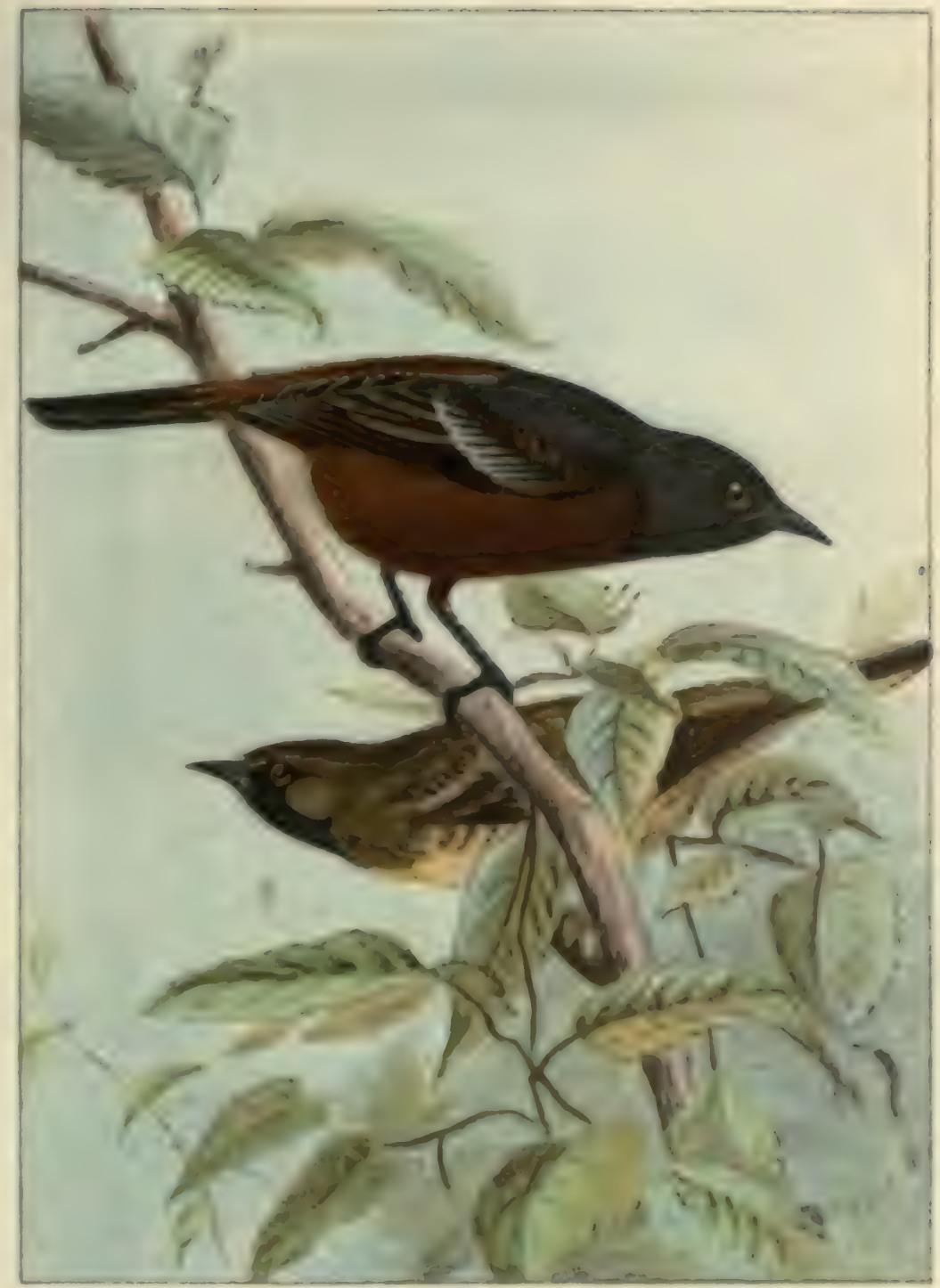

PLAтี XXXVL.

Psan 13:

\section{OROHARD ORTOLR.}

Length, 7.30 Inches. Adsult esule, emwn, hack, sont throat biant, res-

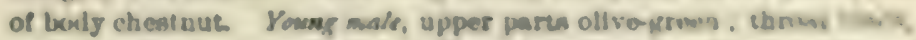

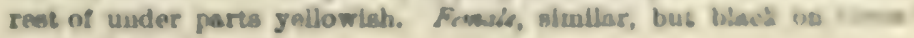
raplaced by jellowish. 

of sumthern New York. It migrates northward in Feb. ruary and March, but does not nest until May. U'nlike our other Ilawke, it chiones a hollow tree for a home, often taking possession of a Wooupecker's deserted hole. It lays three to seven eggs, which are finely and evenly marked with reddish brown.

It is the Sharp-shinned and Cooper's Hawks who are the real culprits in Hawkdom. They feed almost excluDharpahinned Hawk, sively on birds, and, having once acAmpier relias. quired a taste for tender young broilens, Plate XVII. they are apt to make dnily visits to the hen yards. They are less often observed than the Hawks previously mentioned, seeking less exposed perches and surring comparatively little; but, when seen, their slender bolies and long tails should aid in distinguishing them from the stouter, slower-flying Hawks. As a rule, they are silent. It is difficult to explain the differences between these and other Hawks with sufticient clearness to prevent one's killing the wrong kind, but if the farmer will withhold his judgment against Ilawks in general, and shoot only those that visit his poultry yard, he will not go far astray.

Cooper's Hawk resembles the Sharp-shinned in color, but is about four inches longer, and its outer tail-feathers are about half an inch shorter than the

Cooper's Irawk, Anoupuer comperi.

middle ones insteal of being of equal length. With the preceding species it may be known by its slender form, long tail, comparatively short wings, and long, thin tarsi or "legs."

The Chinese and Japanese train Cormorants to fish

Amerteas Oprey, Mndion Aalraeswa cambinenaie. Plate XVIII. for them, but the services of these birds would soon be at a discount if the Osprey could bo induced to work for a master. What an inspiring sight it is to see one plunge fron the air upon its prey! One can 
sometimes hear the splash half a mile or more, and the bird is quite concealed by the spray. It is a magnificent performance, and when, after shaking the water from his plumage, he rises into the air, I am always tempted to applaud.

The Osprey, or Fish Hawk, as he is also called, adheres closely to a finny diet; neither flesh nor fowl appears on his menu, and he is consequently a migratory bird, coming in April when the ice has melted and remaining until October. In favorable localities he nests in colonies, returning year after year to the same nest.

One master, it is true, the Osprey has, though he makes a most unwilling servant. The Bald-headed Eagle is often an appreciative observer of the Osprey's

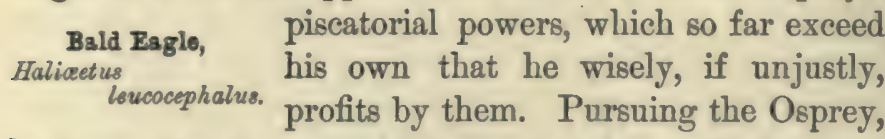
he forces him to mount higher and higher until the poor bird in despair drops his prize, which the Eagle captures as it falls.

Eagles are becoming so rare in the Northern States that their occurrence is sometimes commented on by the local press as a matter of general interest. Nevertheless, no opportunity to kill them is neglected, and the majestic birds who in life arouse our keenest admiration are sacrificed to the wanton desire to kill.

\section{The OWLS. (FAMILY BUBONID正)}

The Owls number about two hundred species, and are distributed throughout the world. As a rule they are nocturnal or crepuscular birds, passing the day in hollow trees or dense evergreens, and appearing only after nightfali; but there are some diurnal species, such 


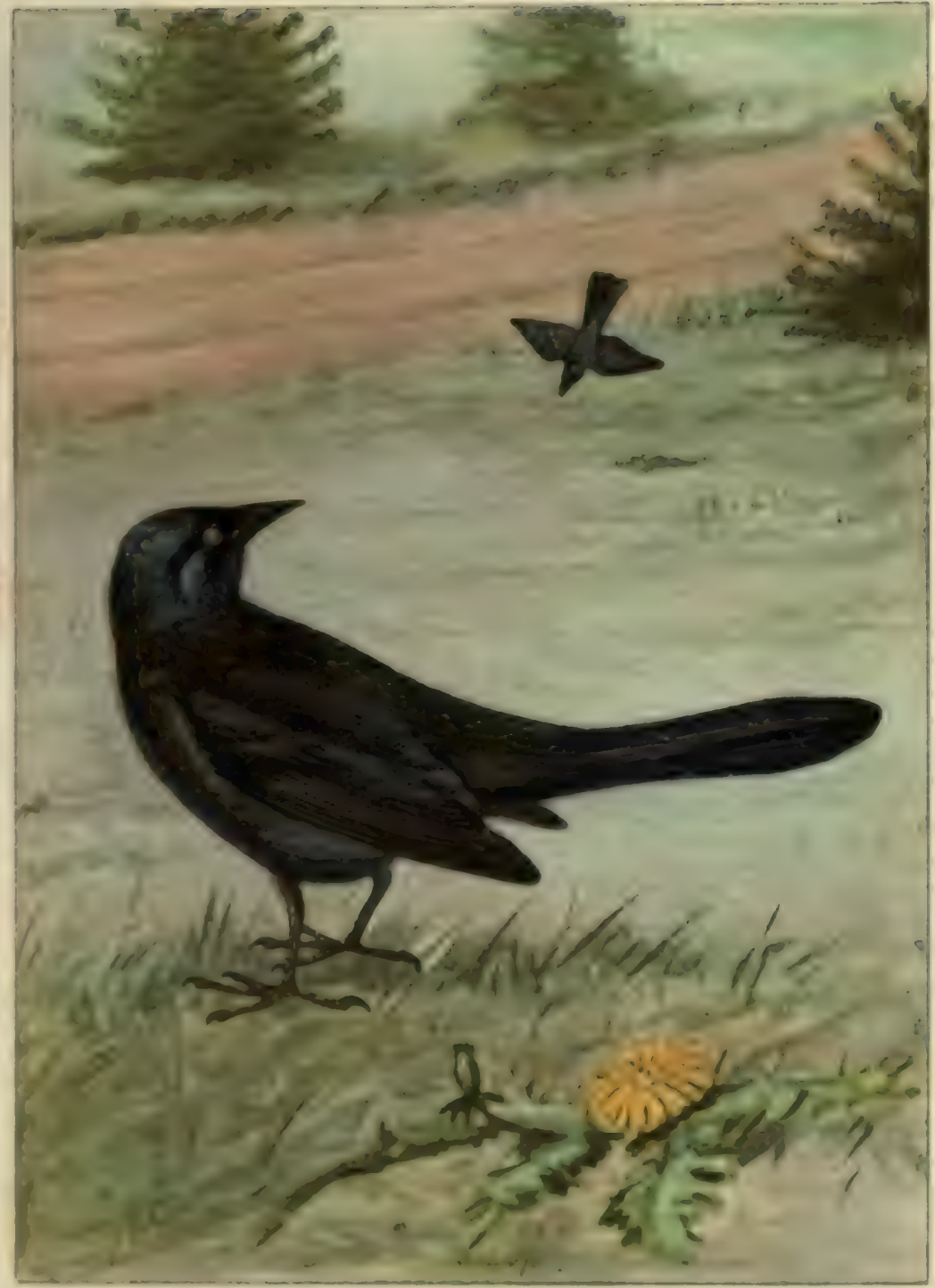

Рият XXXVIT.

\section{PORPLE GRACKLE.}

Page 193.

Length, male, $19-10$ Inches; fomnle, 1100 inches Male, head, neck, throat, and breast bright metallio blue, purple, or green; beck with Iridesent bars; belly paler; eje pale yellow. Female, muah duller than male. 

as the Sinowy Owl and IIswk Owl, northern birds that visit us rarely in winter.

Because of their nocturnal habits $O$ wls are even more deserving of protection than the beneficial IIawks, for they feod at a time when mice are abroad, and their fool consists largely of these destructive little rodents. They eapture their prey, like the Ilawks, by striking it with their powerful talons, when, if small enough, it is swallowed entire. The indigestible portions, hair, bones, and featlers, are formed into pellets in the stomach and ejected at the mouth. These may always be found in numbers beneath an Owl's roosting place, and form as sure an indieation of the Owl's presence as they do of the nature of his food. Thus, as before mentioned, two humlred pellets of the Barn Owl, taken from the home of a pair of these birls in the tower of the Smithsonian Institution, were found by Dr. A. K. Fisher to contain the skulls of 454 small marnmals.

Owls are generilly inhabitants of woods, but our Short-cured $\mathrm{Owl}$ is an exception to this rule, and lives

Bert-eared $0 \mathrm{w}$, dow ascipilrin us.

Plate XIX. in large, grassy marshes. It passes the day on the ground, but at dusk may be seen flying low over the marsh in search of the meadow mice which form a large part of its food. Dr. Fisher found, on exnmination of 101 stomachs of this Owl, that no less than 77 contained the remains of mice, convincing proof of its usefulness. Unlike any of our other Owle, the Short-eared makes its nest on the ground, laying from four to seven eggs. It is somewhat irregular in its distribution, but has been found nesting, locally, from Virginia northwand. It winters from New Jersey southward, and is sometimes associated in compunies at this season.

The Long-eared $\mathrm{O} w \mathrm{l}$ is about the size of the Shorteared Owl, but its "ear-tufts" are an inch or more in 
length, and its sides and belly are barred, not streaked, with blackish. It does not frequent marshes, but lives in swampy thickets or dense woods, and

Long-eared 0w1, Asio vilsonianus. makes its nest in the abandoned home of a Crow, Hawk, or squirrel. It is a permanent resident from at least Massachusetts southward.

Of our four "horned " Owls, the Long-eared has relatively the largest and most conspicuous "ear-tufts," the Short-eared the smallest, while in the Great Horned Owl and Screech Owl the ears are of about the same proportionate size. The Great Horned $\mathrm{Owl}$, however, is found only in the wilder, more heavily wooded parts of the country, and is hardly to be included in a list of our common birds. It is the largest of our resident Owls, the males measuring twenty-two inches in length, while its "eartufts" are nearly two inches long.

The Screech Owl is doubtless the commonest of our Owls, as it is also the most familiar, nesting about and

\section{Soreech Owl,}

Megascops ario.

Plate XX. even in our houses when some favor-. able hole offers. It has little to say for itself until its family of four to six fuzzy Owlets is safely launched into the world; then, in July or August, we may hear its melancholy roice-not a "screech," but a tremulous, wailing whistle. It has several other notes difficult to describe, and when alarmed defiantly snaps its bill.

Some Screech Owls are gray, others bright reddish brown, and these extremes are connected by specimens intermediate in color. This difference in color is not due to age, sex, or season, and is termed dichromatism, or the presence in the same species of two phases of color. The same phenomenon is shown by other birds, notably certain Herons, and among mammals by the gray squirrel, some individuals of which are black. The observa- 


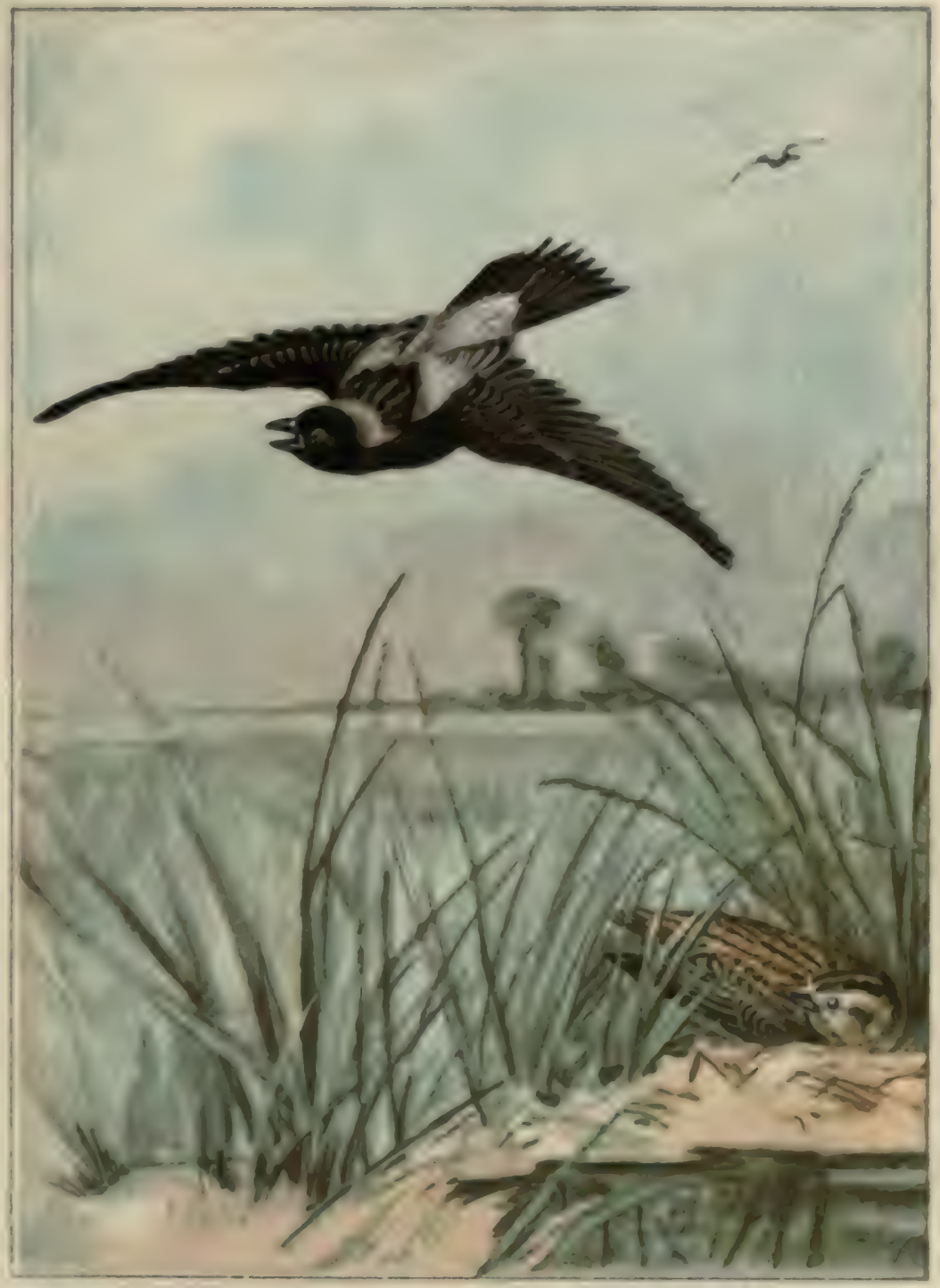

PLate XXXVII.

BOBOLINK.

Plas 13.

Leagth, 7.25 Inches. Male, in numwer, nape buff; shoulders and rump whitisb; crown and under parts black. Frmole, young, and male in wimer, sparrowlike; upper parte black, brownlsh, and buffy; under parts jellowiah white. 

tions of Dr. A. P. Chadbourne apparently show that the Screech $\mathrm{OWl}$ may pass from one phase to another without change of plumage."

We do not think of $\mathrm{Owls}$ as being insectivorous birds, but Dr. A. K. Fisher tells us that of 225 Screech Owls' stomachs examined, 100 contuined insects. As 91 of the remaining 125 contained mice, and poultry was found in only one stomach, the farmer may well consider the Sereech $\mathrm{Owl}$ a bird of good repute rather than of ill omen.

Next to the Screech Owl the Barred Owl is doubtless our most common representative of this family, but its

Barred 0wh, fondness for deep woods prevents its Syrnium nebulasum. being known to many who recognize the Plate XXI.

Screech Owl's mournful song.

In both voice and appearance the Barred $\mathrm{Owl}$ seems the most human of our Owls. Its call is a deep-roiced

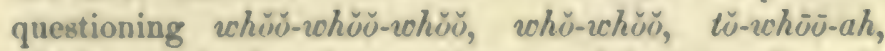
which may be heard at a distance of half a mile. It echoes through the woods at night with startling force, and the storics told of its effect on persons who were ignorant of its source are doubtless not without foundation.

Other calls are a long-drawn $v h \bar{\delta}-\bar{\delta}-\bar{\delta}-\bar{j}-\bar{a} h$, and rarely a thrilling, weird shriek. When two or more Owls are together, they sometimes join in a most singular concerted performance. One utters about ten rapid hoots, while the other, in a slightly higher tone, hoots ahout half as fast, both birds ending together with a whisi-ah. At other times they may hoot and langh in a most remarkable and quite indescribable manner.

The Barred Owl feeds largely on mice, and 46 of 100 stomachs examined contained remains of these rodents.

- The Auk (New York city), xiii, 1896, p. 321 ; xiv, 1897, p. 88. 
It is generally resident throughout its range, and in March makes its nest, selecting for a site a hollow tree, or the deserted home of a Crow or Hawk. Two to four eggs are laid, which, like the eggs of all Owls, are pure white.

\section{CUCKOOS, KINGFISHERS, ETC. (ORDER COCCYGES).}

\section{Cucroos. (F AMILY CUCULID AE.)}

AlL Cuckoos have two toes directed forward and two backward, but the cause or use of this character it is difficult to understand, so widely do the members of this family differ in habit. Some are arboreal, never visiting the earth, while others are terrestrial, running with great swiftness, and rarely perching far above the ground.

Most Cuckoos-all our thirty-five American specieshave noticeably long tails, which they raise and droop slowly just after alighting, or when their curiosity is aroused.

Of the one hundred and seventy-five known species, only two are found in the northeastern States-the YelYellow-billed Cuokoo, Coccyzus americanus. The former is generally the more comPlate XXII. mon. It is a retiring bird, and you will donhtless be first sttracted to it by its notes. It does not perch in an exposed position, nor make long flights, but usually flies from the shelter of one tree directly into the protecting foliage of another. If you catch a glimpse of it in passing, its long tail and brownish color will suggest a Dove.

Cuckoos are mysterious birds well worth watching. I would not imply that their deeds are evil; on the contrary, they are exceedingly beneficial birds. One of their favorite foods is the tent caterpillar which spins the 


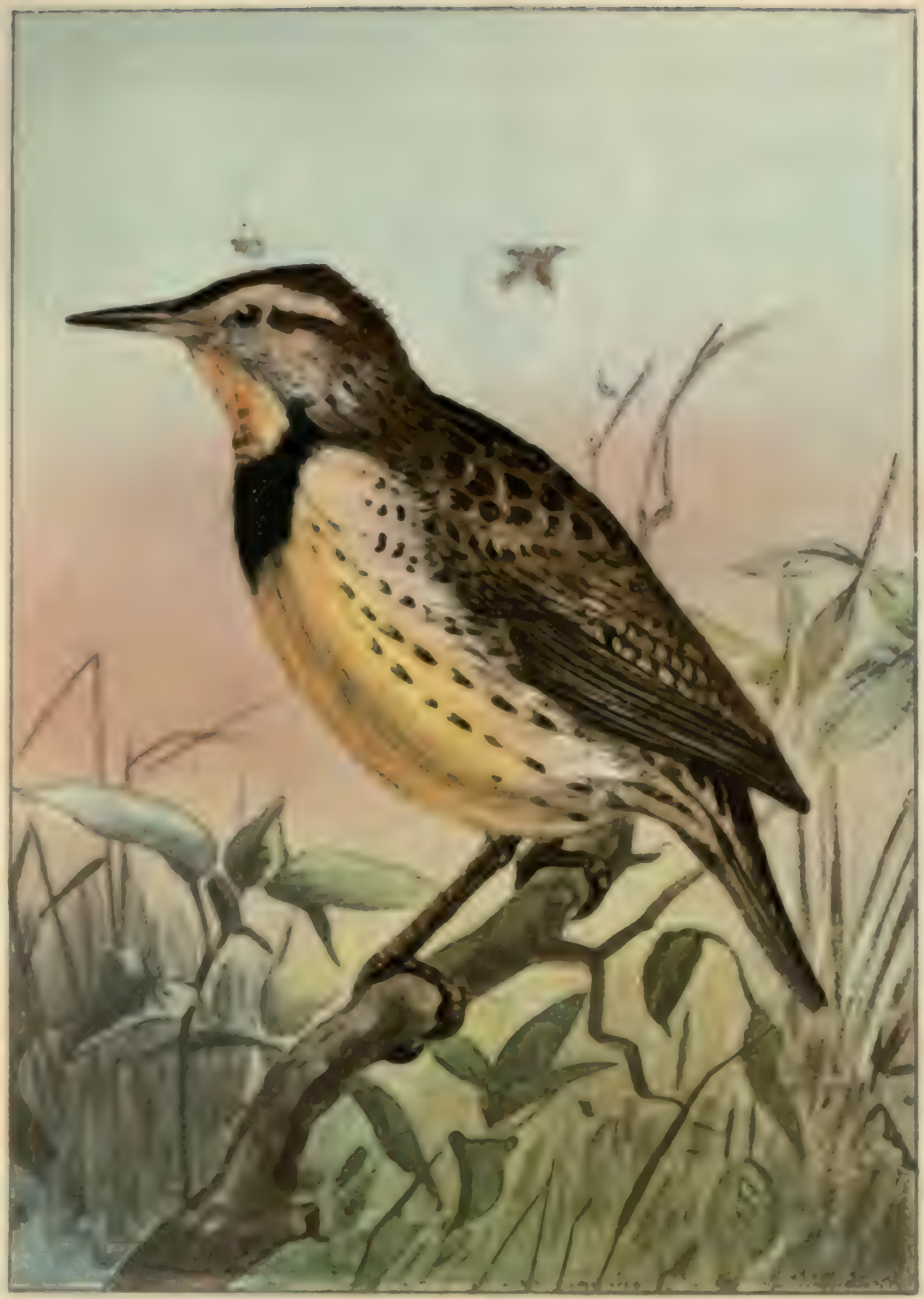

Plate XXX1X.

PAar 136.

\section{MEADOWLARK.}

Longth, 10.75 inches. Upper parts black, brown, and buff; under parts yellow, s black orescent on the breast, sides streaked with black; outer tall-feathers white. 

destructive "worms" nests" in our fruit and shade trees. Inleod, we should be very much better off if Cuckoos were more numeruus. Nevertheles, there is something about the Cnckoo's actions which always suggests to me that he either has just done, or is about to do, something he shouldn't.

The Yellow-billed Cuckoo's call begins with a series of tul-tuts or cl-uckin, and ends with a loud cono, conv, cono, conc, cove, cono. These noies are so unlike those of any other of our birds, except those of the Black-billed Cuckoo, that they will readily be recognized.

The Black-billed Cuckoo resenules the Yellow-bill, but has the bill wholly black, the skin about the ejo red, Black-billed Cuekoo, and the tail-feathers with only sniall, Cisecysus inconspicuous whitish tips. It resem-

eryehrophehulmus. bles the Yellow-bill in habits, but, as Mr. Brewster tells me, its tut and cluck notes are softer, and the cono-cono notes are connected.

Both our Cuckoos are migratory, wintering in Central and South America. They return to us about May 5 , and remain until October. Their nests are carelessly nade platforms of sticks with a few catkins added as a lining, and are usually placed in tangles of vine-corered bushes, or the lower limbs of trees. The eggs, three to five in number, are pale, greenish blue, those of the Black-bill heing slightly smaller in size and darker in color than those of its yellow-billed cousin.

\section{KiNaFtBHERs. (FAMILY AlCEDINID A.)}

Of the one hundred and eighty known Kingfishers, only eight are inhabitants of the New World, the headquarters of the farnily heing in the East Indies. The New Worlul species are mostly tropical, and but one of the eight reaches the eastem United States. This is our common 
Belted Kingfisher, familiar by voice and appearance to every one who lives near a river or pond. He comes Belted Kingfisher, in April, when the ice no longer covCeryle alcyon. ers his hunting ground, and remains

Plate XXIII. until November; or, if the season be exceptionally mild, he sometimes stays for the winter fishing. His nest is built in a hole in a bank, where, early in May, his mate lays from five to eight white eggs.

The Kingfisher is generally branded a fish thief and accounted a fair mark for every man with a gun, and, were it not for his discretion in judging distances and knowing just when to fly, he would long ago have disappeared from the haunts of man. We might now be a few fish richer, but would they repay us for the loss of this genins of wooded shores?

\section{WOODPECKERS AND WRYNECKS. (ORDER PICI.)}

\section{Woodpeckers. (FaMily Picid}

THE three hundred and fifty known species of Woodpeckers are represented in all the wooded parts of the world except the Australian region and Madagascar. Nearly one half this number are found in the New World, and of these twenty-five occur in North America.

Few birds seem better adapted to their mode of life than Woodpeckers, the structure of their bill, tongue, tail, and feet being admirably suited to their needs.

The notes of Woodpeckers can not be termed musical, and their chief contribution to the springtime chorus is a rolling tattoo which resembles the $k-r-r-r$-ring call of the tree frogs. The feathered drummer selects a resonant limb and pounds ont his song with a series of strokes de- 


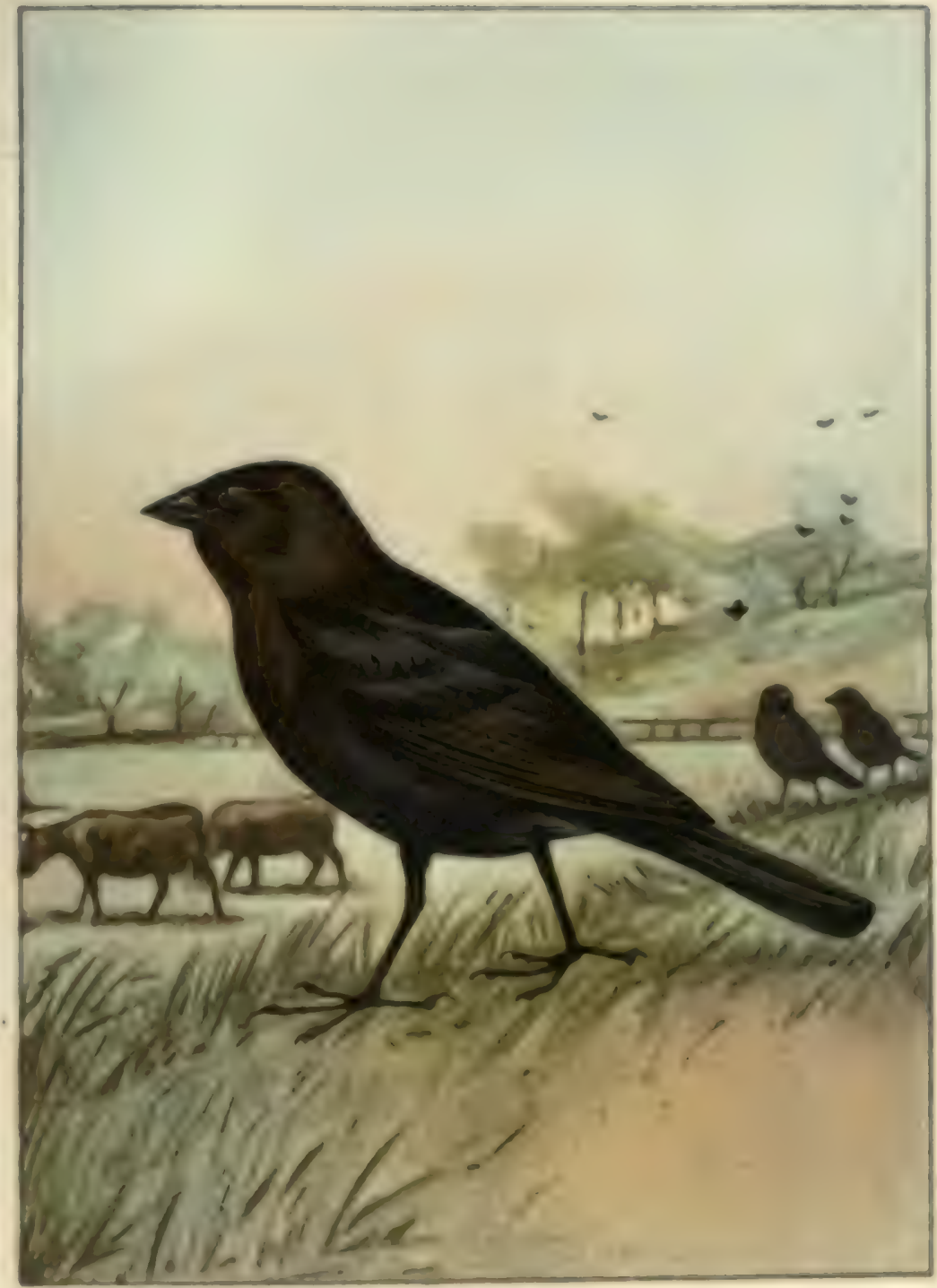

Plate IT.

Pras 18.

COW BIRD.

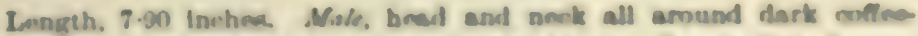

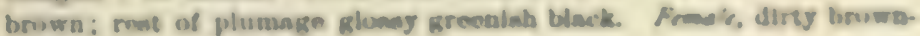
lob Bray: throes whleth. 

livered so quickly that his head becomes a series of mazy heads.

Watch the Downy Woodpecker, our commonest species, while he is engaged in this surprising performDowny woodpecker, ance. How he seems to enjoy it! His linybuse pubroceno whole appearunce is martial and defiPlato XXIV. modianus. ant. It is his challenge to the Woodpecker world. After ench roll he looks proudly sbout him and perhaps utters his call-note, a sharp peek, pwek, which suggests the sound produced by a marlile cutter's chisel. More rarely this call is prolonged into a convected series, when one can readily imagine that the quarrier has dropped his tool.

The Duwny is a hardy bird and is with us throughout the year. In the winter he forms a partnenship with the Chickadee and Nuthatch, and if the good this trio does could he expresied in figures, these neglected friends of uun miglit receive some small part of the credit due them. Who ean estimate the enormous numbers of in. sects' eggrs and Iarva which these patient explorers of truak and twig destroy?

The Downy, as well ss some other Woodpeckers, belieres in the comfort of a home. He will not pass cold, wintry nights clinging to the leeward side of a tree when ly the use of his chisel-hill he can hollow a sung chamber in its heart. So, in the fall, we may sometimes find him preparing his winter quarters. Ir nest is constructed in the same manner, and his eurgs, like those of all Wood. peckers, are glossy white.

The Hairy Woodpeeker, the Downy's big cousin, is not quite so common as his smaller Balsy Woodpoeker,

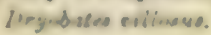
relative. The two birds are nearly alike in color, and differ only in the markings of the outer tail-feathers. In the Downy these are white, harrel with blark; in the IJairy, white withont 
black bars. The case is interesting, and shows how nearly alike in color distinct species may be. In size, however, the difference is more noticeable, the Hairy being nearly three inches the longer.

In life the Hairy is a somewhat shier bird, fonder of the forest than of the orchard. His peek note is louder and sharper than that of the Downy, and his rattling call suggests that of the Kingfisher.

The gayly colored Red-headed Woodpecker is as erratic in his goings and comings as he is striking in Red-headed dress. In the northeastern States he is

Woodpeokrs. locally common in summer, and if well Melanerpes supplied with beechnuts, may remain erythrocephalus. during the winter. Some years the Plate XXV.

grayish headed young birds are exceptionally abundant in the fall, but their white wing-patches, which show so conspicuonsly when they fly, and their loud, rolling call of ker-r-muck, ker-r-ruck, are unmistakable marks of identity.

The most interesting of our Woodpeckers is the Flicker, or High-hole, whose popularity is attested by

Flícker,

Colnptes auratus.

his list of no less than thirty odd comPlate XXVI.

mon names. Surely here is an instance illustrating the necessity of one scientific term by which the "Piquebois jaune" of Louisiana may be recognized as the "Clape" of New York. $\mathrm{He}$ is also a Yucker, a Flicker, and a Yellow-hammer; all these names being based on his notes or plumage.

The Flicker is less of a carpenter than are others of his faunily, and generally selects decayed logs and stumps as his hunting grounds. Here he hunts for his favorite food of ants, which he also procures at their holes and mounds. This is the reason we so often flush the Flicker from the ground, and, if we mark the spot from which he 


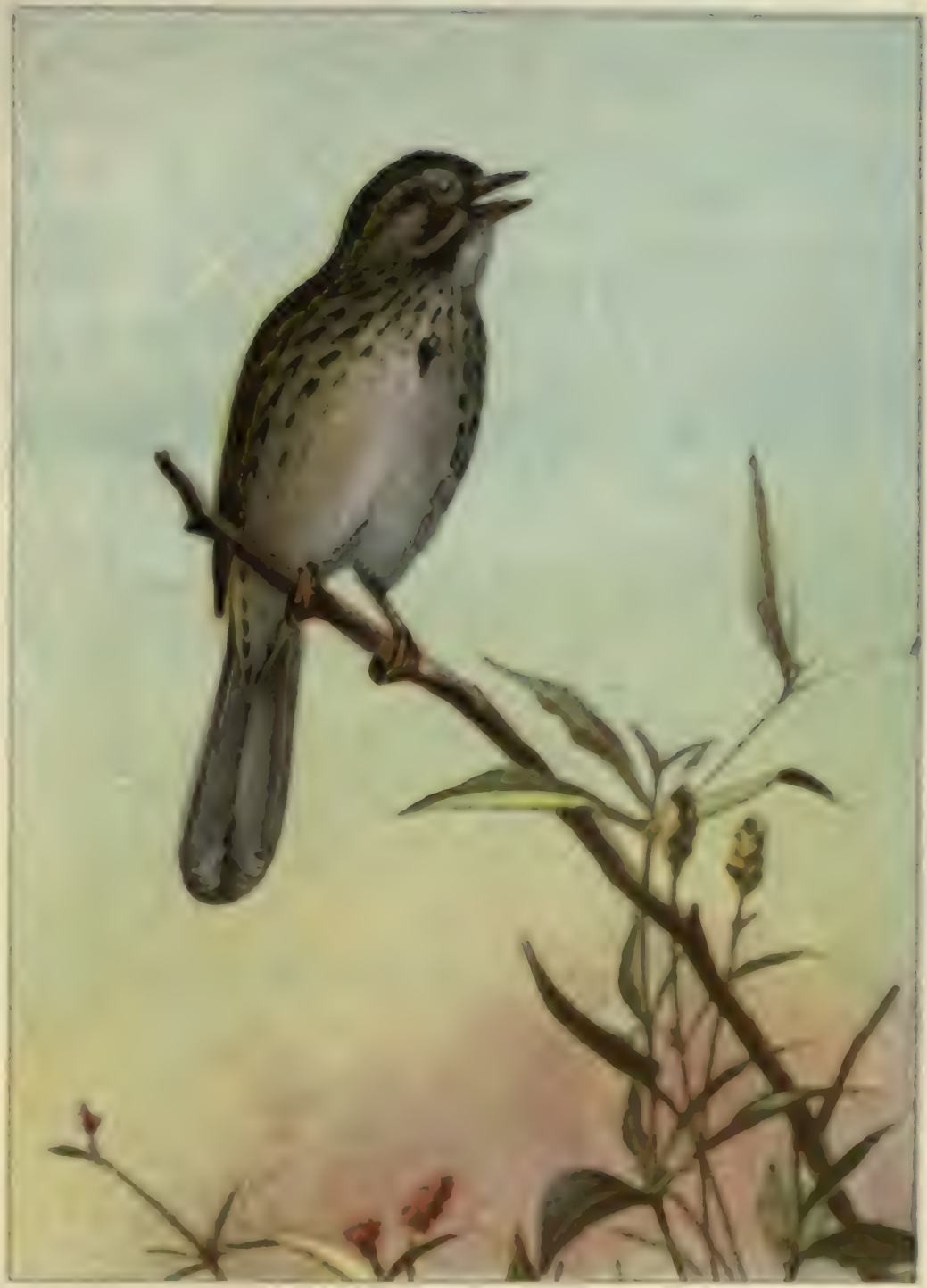

Plate XII.

Paor 8 sm.

\section{EONO EPARROW:}

Length, 6.25 Inctea I'pper parts ebrotnut. may, and Mlants; under parts white, streaked with ebeotnut and black; outer Lail-fmotbent shortest. 

rises, the probabilities are that we shall find there a smuch. disturbenl comunuity of ants.

Profeseor Beal has blown that nearly one half of the Flicker's food consists of ants. He further tells us that as ants aid in the incresse of the plant lice mo injurious to vegetation, the binls which feed on ants are therofure the friends of the agriculturist.

The Flicker's must prominent marka, as with a low chnckle be bounds up befure you, are his white runuy patch and his wings, which show yellow in flight. His notes ane eyually chara-teristic. The most common is a loud, vigorous kie-yer, apparently a signal or salute. In the spring, and occusionully in the fall, he utten a pless. ing, rather dreamy cüh-cuhh-cibh-ciuh, many times repeated. When two or more birls are together, and in my experience only then, they aldress each other with a

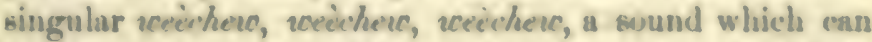
he imitater by the swishing of a willow wand. Much ceremony evidently prevails in the Flicker family, and on these occasions there is more bowing end scruping than one often sces outside of Spuin.

\section{GOATSUCKERS, BWTPTS, AND FUMMTABTRDE. (ORDER MACROCHIRES.)}

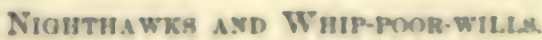
(Fayily Captarorotba.)

Is this family the mouth of birls resches its grentent development, while the lill proper is correspondingly small, bearing mu h the same relation to the mouth that a clasp does to a purse. These binds feed at night upon inserts which they catch on the wing, and their enormous gape is obviously of great amistance in this morle of fcerl. ing. Often the sides of the mouth are beset with long 
bristles, which doubtless act like the wings to a fish-net, steering unfortunate insects down the bird's cavernous throat.

The Nighthawk, or Bull-bat, as he is called in the South, is familiar to most persons who have the gift of $\begin{array}{cl}\text { Nighthawk, } & \text { seeing birds, but-in the northeastern } \\ \text { Chordeiles } & \text { States, at least-he is usually confused } \\ \text { virginianus. } & \text { with the Whip-poor-will, and little is } \\ \text { Plate XXVII. } & \text { known of his real character. }\end{array}$

The Nighthawk is a bird of the sky. He passes the day perched motionless on a limb in wooded regions, on the ground in treeless regions, or even on a house top, when, as sometimes happens, he makes his home in a city. Probably he will not change his perch during the day, but as night approaches and his day begins, he will spread his long wings and fly away heavenward to course far above the earth in his search for insect food.

The Nighthawk, unlike most members of its family, has limited vocal powers, its only note being a loud, nasal peent uttered as it flies. But it has musical talents in another direction. Sometimes in May or June, if you happen to be where Nighthawks are found-for they are rather local in distribution when nesting-you may hear a strange booming, rushing sound; you will vainly seek its cause until you chance to see a Nighthawk with set wings diving earthward from the sky. It is a reckless performance, and you may suppose the bird's object is suicidal, but, when within a few yards of the earth, it will turn suddenly upward. At this moment you will hear the loud, humming sound, dou'tless made by the air passing through the bird's stiffened wing-quills.

Nighthawks, being insect-catchers, are of course highly migratory. They come to us early in May, and return to their winter quarters in South America in Oc- 


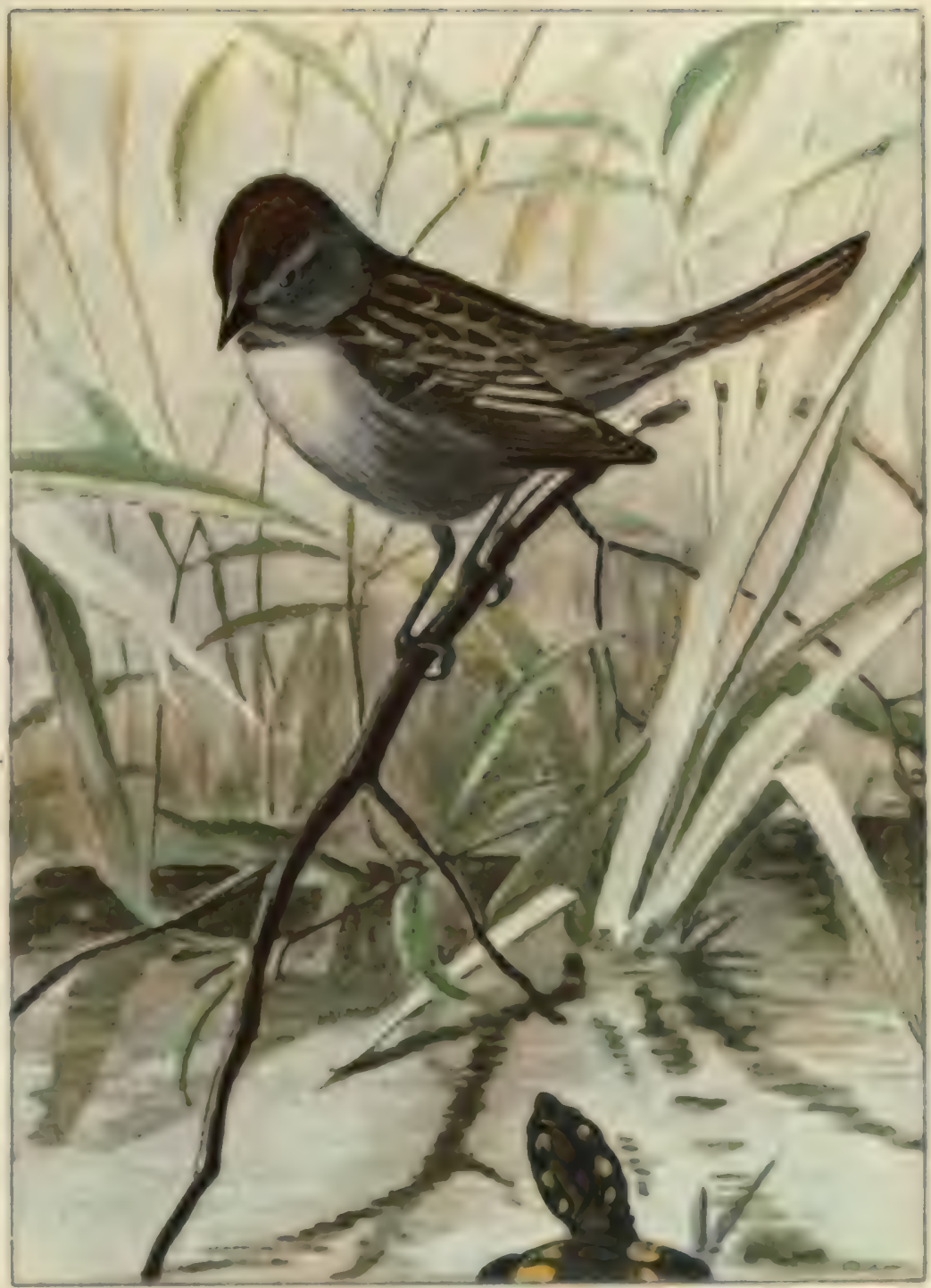

DTAT XLII.

PaOA 130.

\section{BWAMP SPARHLW,}

Leagth, B.90 Inchea. Sunwer Abumagr, erown bright chestrut : beck black, brown, and buff; breast kroytab; belly whlte ; aldes brownich. Winser pinemagre, aimillar, but crown stresked with cheatnut-brown black, ad gray. 

tober. During the fall migmations they often gather in flocks of several hunctred, and as they sail alwout you may notice their best field mark, a white spot in each wing. Nighthawks lay two elliptical, muttled egghs on the bare ground or a flat rock in open fields, and, rarely, on a honse top in the eity.

We see the Nighthawk and hear the Whip-poor-will; one reason perhaps why the birds are so often confuserl. Whip-poor-wll, While the Nighthn wk is darting through Antrostomus teiferma. the sky, the Whip-poor-will is perched

Plute XXVil. on a rock or fence rail below, industriously whipping out a succession of mpid velip-powvoills interspersed with barely audible chucks. When the call ceases, the bird is donbtless counsing low through the wooded fields and glades in its search for insects.

During the day the Whip-poor-will usually rests on the ground in the woods. Here also. the eggs are laid, being deposited upon the leares. They are two in number, dull white, with delicate, obscure lilac markings and a few distinct brownish gray spots.

Whip-poor-wills arrive from the south late in April, and remain with us until October.

\section{SwIFT8. (FAMILY MICROMDID R)}

Swirts are the most aêrial of all the small land liris. Our Chimney Swift, the only one of the seventy-five Chimnoy swith members of this family that occurs in Chatures polumpien. eastern North Amerien, is but five and

Plate XXviu. a half inehes long. while its spread wings measure twelve and a half inches from tip to tip. Its feet are proportionately small, and so weak that the bird can rest only by clinging to an upright surface. The tail is then used as a prop, its spiny-tipped fenthere being evidently a result of this habit. 
Swifts naturally nest in hollow trees or caves, and it is only in the more densely populated parts of their range that they resort to chimneys and outbuildings. The nest of our Chimney Swift is a bracketlike basket of small twigs. They are gathered by the bird while on the wing, and are fastened together and to the wall of the tree or chimney with a glutinous saliva.

The Chimney Swift arrives from the south about April 20, and remains until October. Few birds are better known, and under the name of "Chimney Swallow" he is familiar to every one who distinguishes a Crow from a Robin. But, beyond similar feeding habits, Swifts have little in common with Swallows; in fact, are more nearly related to Hummingbirds.

\section{Hummingirds. (Family Trochilid ze.)}

Humming arrds are peculiar to the New World. About five hundred species are known, but only one of them is Raby-throated found east of the Mississippi. This is

Hummingbird, our Ruby-throat, the sexes of which are Trochilus colubris. sometimes thought to represent differPlate XXIX. ent species. The Ruby-throat winters as far south as Central America, but about May 1 we may expect him to return to us, for he is as regular in his migrations as though his wings measured a foot and a half instead of an inch and a half in length. If you would have him visit you, plant honeysuckle and trumpet flowers about your piazza, and while they are blooming there will be few days when you may not hear the humming of this tiny bird's rapidly vibrating wings.

The Ruby-throat feeds on insects as well as on the juices of flowers, and when you see him probing a corolla he is quite as likely to be after the one as the other. The young are fed by regurgitation, the parent bird insert- 


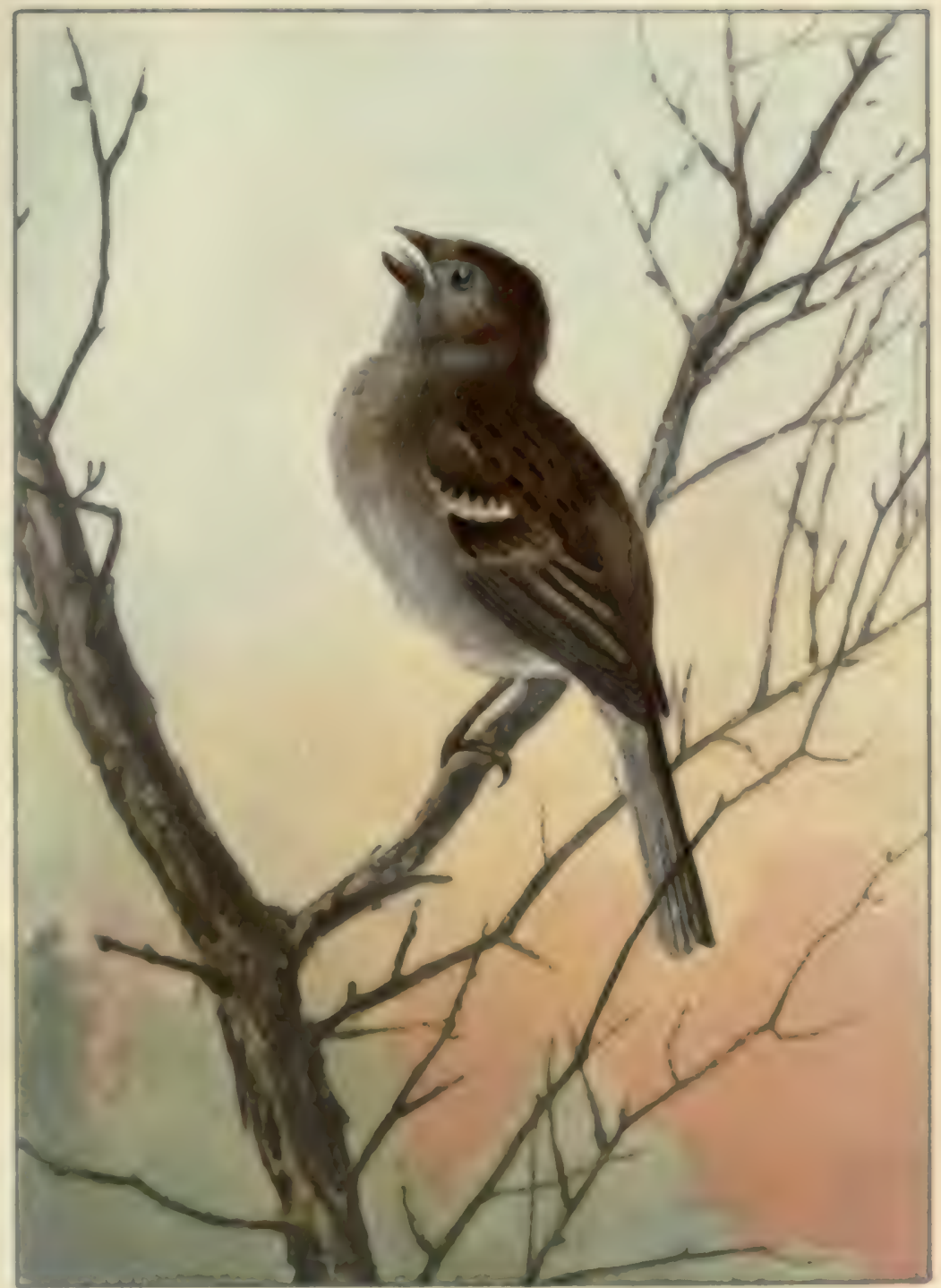

Pимт xIII.

Paen 140.

MELD 8PARROW.

Length, 5.70 Inches Opper parts brieht roddlah brown and black: under parts grastoh whle: bill reddlah brown. 

ing its bill into the mouth of its offupring and injerting food as though from a syringe.

Some tropieal Hummingliods have mongw worthy the name, but the notes of our Ruby-thruat are a mere suguesk, sometimes prolonged into s twitter.

Under any circumstances a Ilumuingtirl's nemt ex. cites admiration. But if you would appre inte its fuirylike besuty, find one where the birds lave placed it, probably on the hurizontal limb of a birch. Douletenes it will be oceupied by the female, for it seems that the male takes litt!e or no part in family affains after incubation begins. As fur as known, all Ilumminglinds lay two white egh - frail, pearly ellipses, that after fourteen days' incula. tion develop into a tangle of tiny dark limls and hoolies, which no one would think of calling birds, moch lewe "wingod gema"

\section{PERCHING BIRDS. (ORDER PASSERES.)}

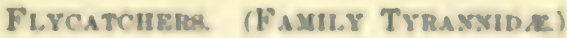

Doentusas, every orler of hir.ls has had its dny when, if it was not a dominant type, it was at least aufficiently near it to be consilered modern : and as we review what is known to us of that great serien of feathered formos, from the Archuopteryx to the Thrushes, we can real. ize how varied has been the chanacteriatic avifiouna of eareh succeeding eproch from the Juraseic perient to the present.

Now has mome the day of the omler Panacrea, the Perching Birds; here belong our Flycatchen. Oriulen Jays, Sparrows and Finchen, Vineon, Swallows, Warblem Wrena, Thrushes, and many othens. A revent autherity claseifies lirds in thirty-four onlen, but fully one talf of 
the thirteen thousand known species are included in the single order Passeres. The North American members of this order are so alike in more important structural details that they are placed in but two suborders, the suborder Clamatores, containing the so-called Songless Perching Birds, and the suborder Oscines, containing the Song Birds. The Flycatchers are the only members of the suborder Clamatores in Eastern North America. They differ from the Oscines, or true Song Birds, in always having ten fully dereloped primaries, in having the tarsus rounded behind as well as in front, and chiefly in the anatomy of the syrinx, or voice-producing organ. In the Oscines this possesses four or five distinct pairs of intrinsic muscles, while in the Clamatores it has less than four pairs of muscles, and is not so highly developed.

Flycatchers are the Hawks of the insect world. Their position when resting is erect, and they are constantly on the watch for their prey, which is captured on the wing, with a dexterity Hawks may well envy. The bill is broad and flat and the gape large, as in other fly-catching birds. After darting for an insect, as a rule, they return to the same perch, a habit which betrays their family affinities, though it is occasionally practiced by some other birds.

Among our Eastern Flycatchers the Kingbird undoubtedly deserves first rank. In books he is sometimes

Kingbird,

Tyrannus tyrannus.

Plate XXX. in a just cause. His particular enemy is the Crow, and during the nesting season each Kingbird evidently draws an imaginary circle about his home within which no Crow can venture unchallenged. From his lookout on the topmost branch of a neighboring tree the Kingbird darts forth at the trespasser, charging him with a spirit 


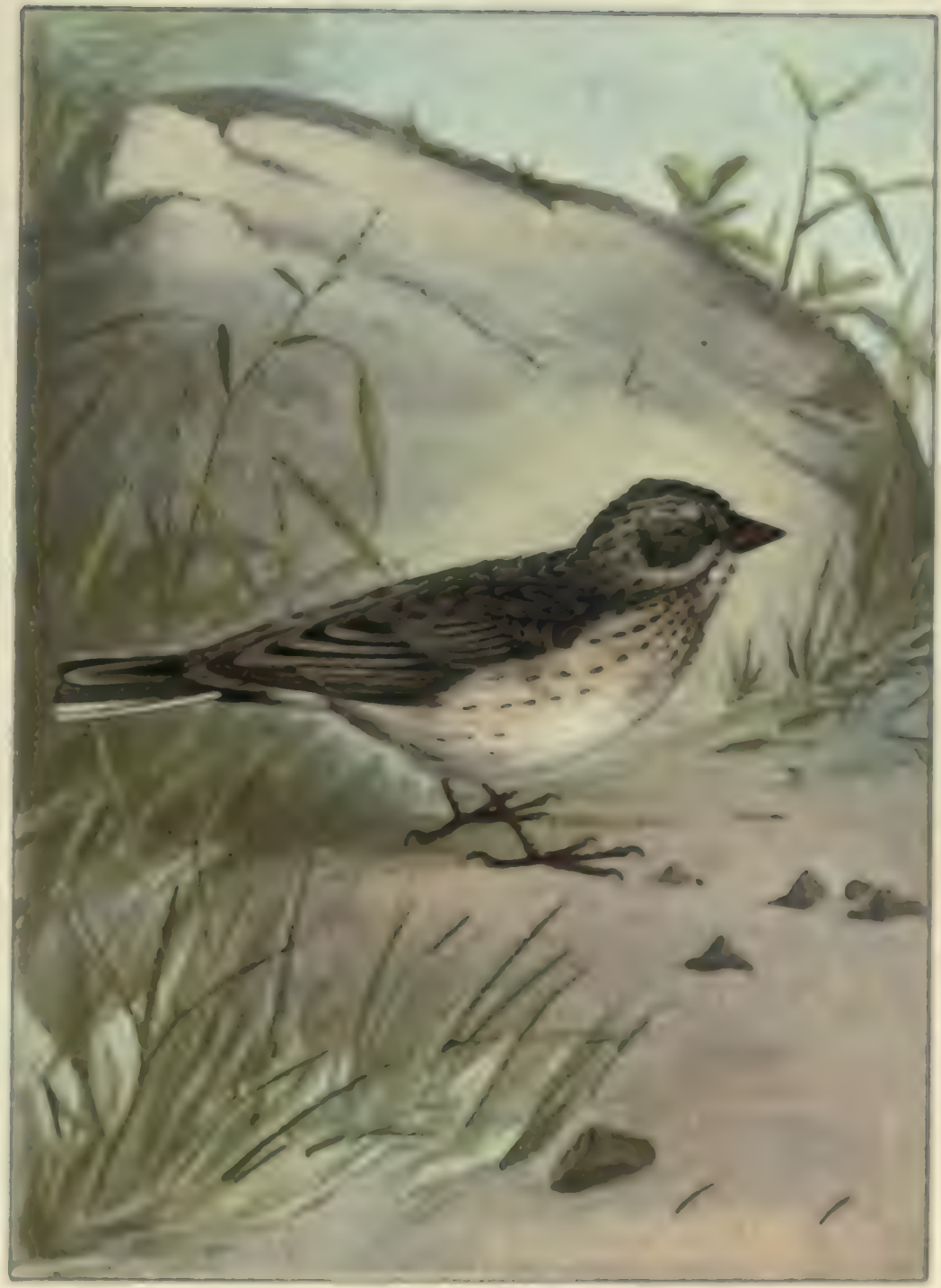

Puate XI.IV.

PaOd 14.

\section{VEAPER RPARBOW.}

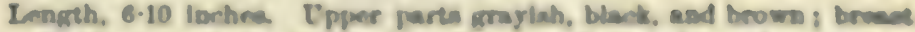

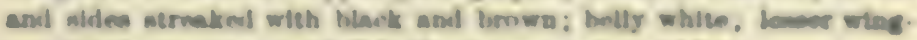
curerto chewtaus; outer talb-fenchen more or lnow whila 

and fearlesenes which no lird can withenand. It is a cano of "right usakes miglit," abled to a very dexterous use of wings and bill. The Crow, if he be experienced, turns tail at once and, lejonil protesting mquarkn, unkes so attempt to defend hituself. But the Kingtbind is deaf to pleas for mercy: he too has had experience, and well knows that ouly his own watchfulness has anved his eggn or young. Fur in the distance be relentlesty pumues his foe, leaving him only when he has ndwinistere.l a lesson which will not be forgotten. Then he returus to his pust and, with crest erect and quivering wings, gives roice to cries of victory.

Bee-keepers accuse the Kinglird of a taste for honeybees, but the examination, made by Prof. Beal, of two - hundred and eighteen Kinglirils' stomachs shows that the elaurge is unfoumled. (Only fourteen stonuachs contained remains of bees, most of which were drones, while sixty per cent of the Kinglinds' food was found to con. sist of injurions insects.

Kingbirls winter in Central and Sonth Anerien, returning to us in the spring alwot May 1, and renaining until sepptember. Their nest is a companct, symuetrional structure of weed stalks, grasees, and mose, lined with plant down, fine grases, and rootleta, and is usually place 1 at the extrenity of a limb alvout twenty foet from the ground. The eggn, three to fire in numler, are white, epotted with chocolate.

The Crested or Great Crested Flycatcher is as a rule. not so common as the Kinghinl, and its habits prevent it crevted Fyeatober, from being mo emily obeervel. King. Myiurseserinisus. biris ean he seen whenever hearl, but Plate XXX1.

you may hear the Grenterest a whistle many times hefore you nee the whistler. Generally he lives in the wools ligh up in the trees, but be is also found in old oreharis. Ilis call, like an exclausation, 
rings out above all other birds' notes. What! he seems to say, and, as though hearing something which not only surprised but amused him, follows this call with a chuckling whistle.

The Greatcrest arrives from the south about May 7, and remains until September. Nesting is begun early in June, a hollow limb being the home usually selected. In collecting its nesting materials, the bird displays a very singular trait, and gives evidence of the stability of habit. With rare exceptions it places a bit of cast snake-skin in its nest. Various reasons have been advanced to account for this singular habit, but none of them is satisfactory. Recently Lieutenant Wirt Robinson has discovered that one of the commonest and most generally distributed species of this genus in South America places cast snake-skin in its nest, and it is well known that the Arizona Crested Flyeatcher follows the same custom. The habit is therefore widespread, and is common to birds living under greatly varying conditions. Rather than consider it of especial significance in each species, it seems more reasonable to believe that it is an inheritance from a common ancestor, and has no connection with the present surroundings of at lesst those species living so far from the center of distribution of this tropical genus as our Myiarchus crinitus.

The Phœbe is domestic; he prefers the haunts, or, at least, handiwork of man, and when not nesting on a beam

Phobe,

Saymrnis phrebe.

Plate XXXII. in a barn, shed, or piazza, selects the shelter of a bridge for a home. Here he places his nest of mose and mud; a structure of generous proportions, for the Phœbe's family may number five or six.

Flycatchers, because of the nature of their food, nsually make extended migrations. For the same reason they arrive late in the spring and depart early in the 


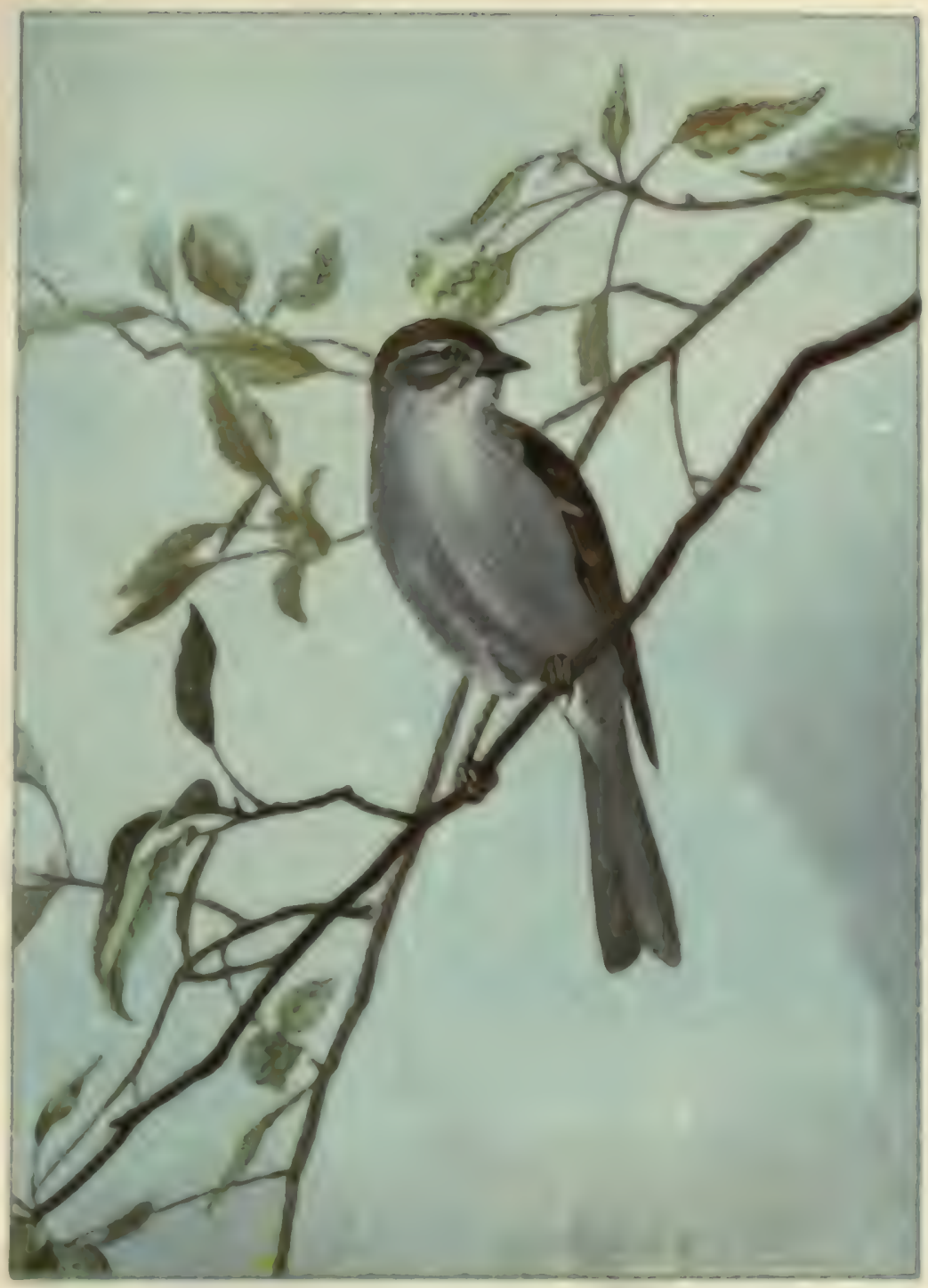

Puars XIV.

Psas 142

CHIPPINO APABROW.

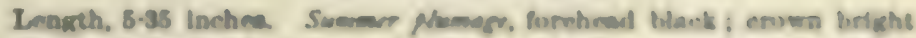

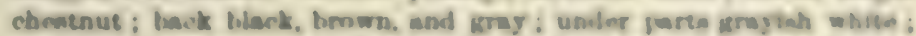

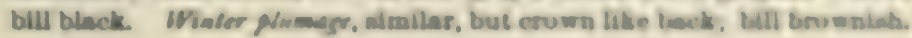



full; but the Phorke is an exception to this rule. Not only does he winter north of the fromt line, but he contes to us as early as Mareh 20 and remains until Oetolver.

The Plughe owes his name to his song of percit-pharlu, percit-phemen, a bumble lay uttered hetween rigorous wags of the tail. This tail-wagging is a chanacterintie motion, and also nceompanies the Phabe's call-note, pwe, pwe, which it uttens at intervals.

The Least Flycateher shares the Phophe's proference for the virinity of houses and is most often found nesting

zoast nyousabor, in our shiule or fruit trees. The nest,

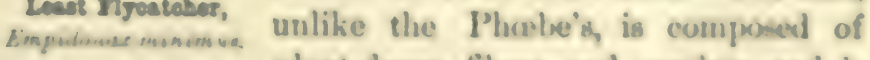
plant-down, fiters, and rootlets, and is placed in the eroteh of a tree. The eggs resemble the Phobe's in being white.

It is difficult to describe our smaller Flycatrbens so that even when in the land they may lee sutisfurtorily identified, and it is quite improssible to describe them so that from color alone they muy lie recognizal in the field. Fortunately, the calls of our commener aperies are so unlike that, when learned, there will be no difficulty in naming their anthors.

To say that the Lenst Flycatcher is five and a lanif inches long, olive-green above and grayiah white helow, does not aid one in distinguinling it from keremal of its cousins: but when I add that its call is a snappy chelic, chelic, the bind will he known the finst time it is heard. It is this eall which has given the hind its common name.

The Cheher comes to us in the spring, about $\mathrm{A}$ pril 25, and remains until September.

You will rarely find two menbers of the snme family with more different dispositions than these of the King. hird and Wount Pewee. Their natures might symbolize war and pesce, no combatice is the Kinglini, mo gentle the 
Pewee. As so often happens among birds, their voices are in keeping with their temperaments. The soft,

Wood Pewee,

Contopus virens.

Plate XXXIII. dreamy pee-a-wee or pee-a-wee peer of the Pewee is as well suited to its character as the harsh, chattering cries of victory are to the Kingbird's.

The Pewee is the last of our more common Fly. eatchers to come from the South, arriving about May 10, and, like the Chebec, remaining until October. It is less social than either the Chebec or the Phøeb. Forests are its chosen haunts, but occasionally it is found on wellshaded lawns and roadsides.

The Pewee's nest rivals the Hummingbird's in beauty. It is a coarser structure, composed of fine grasses, rootlets, and moss, but externally is thickly covered with lichens. Usually it is saddled on a limb from twenty to forty feet above the ground. The eggs, three or four in number, are white, with a wreath of dark brown spots around the larger end.

\section{LARK8. (FAMILY ALAUDIDAE.)}

This family contains the true Larks, birds with long hind toe nails, and a generally brown or sandy colored plumage, the Skylark being a typ.cal species. There are some one hundred species of Larks, but of these only the Horned Lark and its geographical varieties are found in this country.

The variation in colcr shown by the Horned Lark throughout its range is remarkable. From the Mexican

\section{Horned Lark,}

Otocoris alpertris.

Plate XXXIV. tableland northward to Labrador and Alaska no less than eleven different geographical races are known, each one reflecting the influence of the conditions under which it lives, and all intergrading one with another. Only two of 


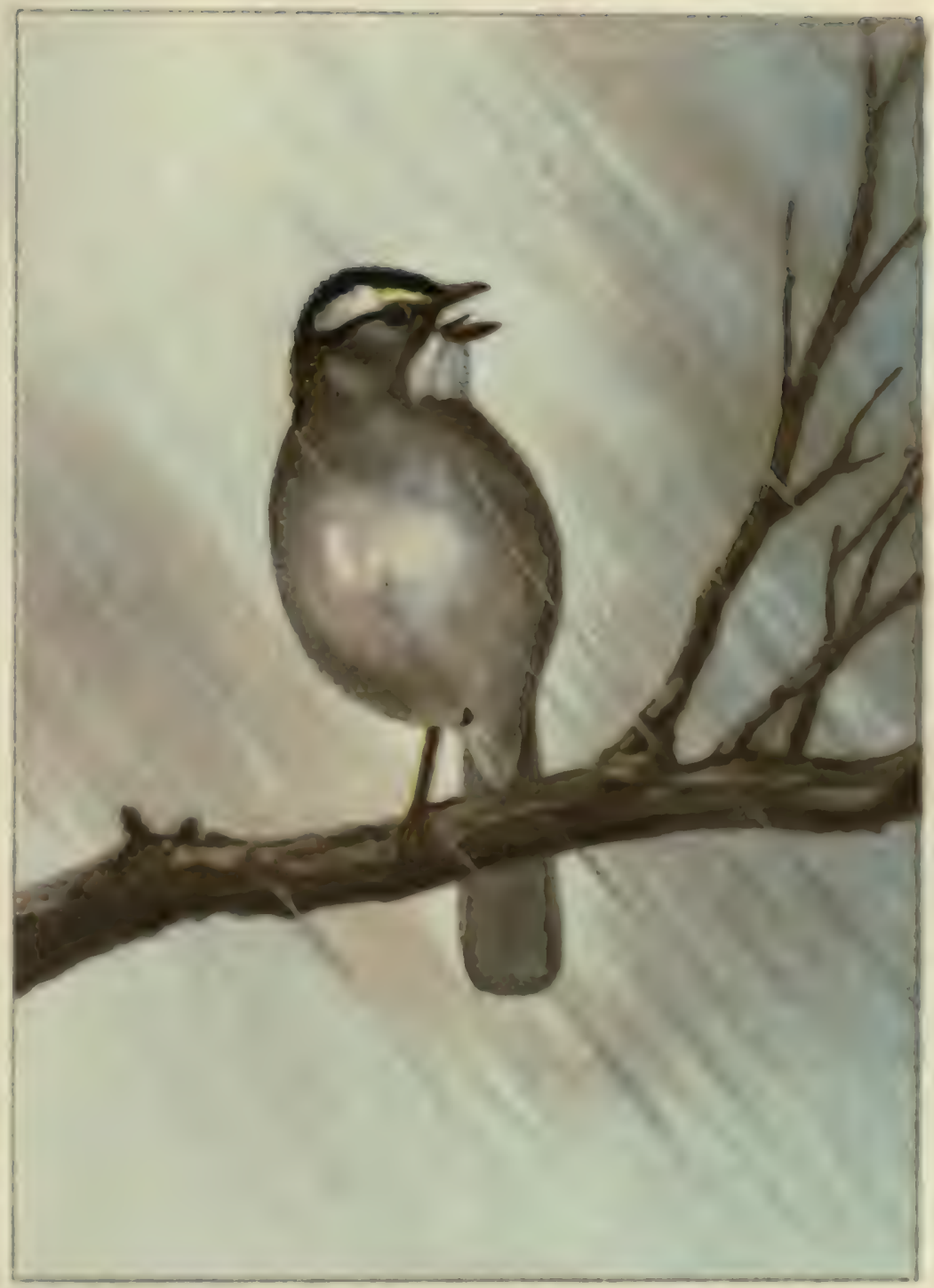

Puare ILVI.

Page 19.

WHTTE-THROATED SPAMIOY.

Length, 6.78 Inches Adw, lom and bead of wing yellow: crowe black and whike: back chestnut-brown, black, and bula; throat wbite:

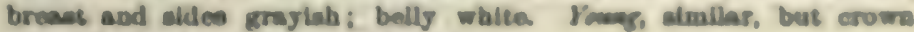
more like back; yellow marking duller. 

these races are found in the eastem linited Staten, tho Horned Lark and the P'nirie llomed lark. The former visits us in the winter; the latter oceuns at all senson, but during the sumuer is found only in certuin regions. At this senson it inhabits the upyer Miminsippi Valleg, whence it extends eanitward through northwentern Pens. sylvania and central New York to weatern Maveachu. setta. From Oetoler to A pril it may be found with the Horned Iark as far south ns South Carolina. The two birds differ in size and color. The Ilorned Iark's wing averages 4.27 inches in length, the Prairie Lark's wing urernges but 4.05 inches in length; the former s forched and eye-line are yellow, the latter's white.

Horned Larks are eminently terrestrial, rarely if ever choosing a higher perch than a fence. When on the ground they do not lop, but walk or run. When flushed they take wing with a sharp, whistled note, but often return to the place from which they started. When nesting. they may be found in fields, pastures, and piains in mattered pairs, but during the winter they are ason. ciaten in flicks, which resort to the vicinity of the seacoast or large open tracts in the interior. The nest in, of course, luilt on the ground. The egas, three or four in number, are pale bluish or greenish white, minutely and evenly spockled with grayish brown.

The Horneal Lark, like its famous relative and many other terremtrial species, sings while on the wing, soaring high above the earth, and often repesting its song many times hefore alighting. The effort is wortly of letter results, for the hird's song is simple and unmusical. 


\section{Crows, JaYs, RTC. (Famli CORVID}

There are systematists who think that the members of this family should hold the place usually assigned the Thrushes, at the head of the class Aves. Leaving out of the case anatomical details whose value is disputed, we might object to a family of songless birds being given first rank in a group whose leading character is power of song. But while Crows and Jays may, from a musical standpoint, be considered songless, no one can deny their great vocal powers. Song, after all, does not imply high rank in bird-life, and some of the sweetest singers (among others, some Snipe, and the Tinamous and Wood Quail of South America) are not members of the suborder of Song Birds.

If, however, the relative intelligence of the two families be taken into account, there can be no doubt that Corvidae fully deserve to be considered the most highly developed of birds. How many tales are told of the human actions of the Raven, Rook, Jackdaw, Magpie, Jay, and Crow!

Of the two hundred members of this family, six inhabit eastern North America, by far the most common being the Crow. No one of our birds Amarioan Crow,
Corvus americanus. is better known, and still, how ignorant

we are of his ways! I am not sure that he does not know more about ours. We have not even recorded his notes, for, in spite of the current opinion that the Crow's calls are restricted to canv, he has an extended vocabulary. I am not aware that he ever ascends to the height of a love song, but that he can converse fluently no one who has listened to him will question. Of the variants of caw, each with its own significance, there seems no end; but if you would be 


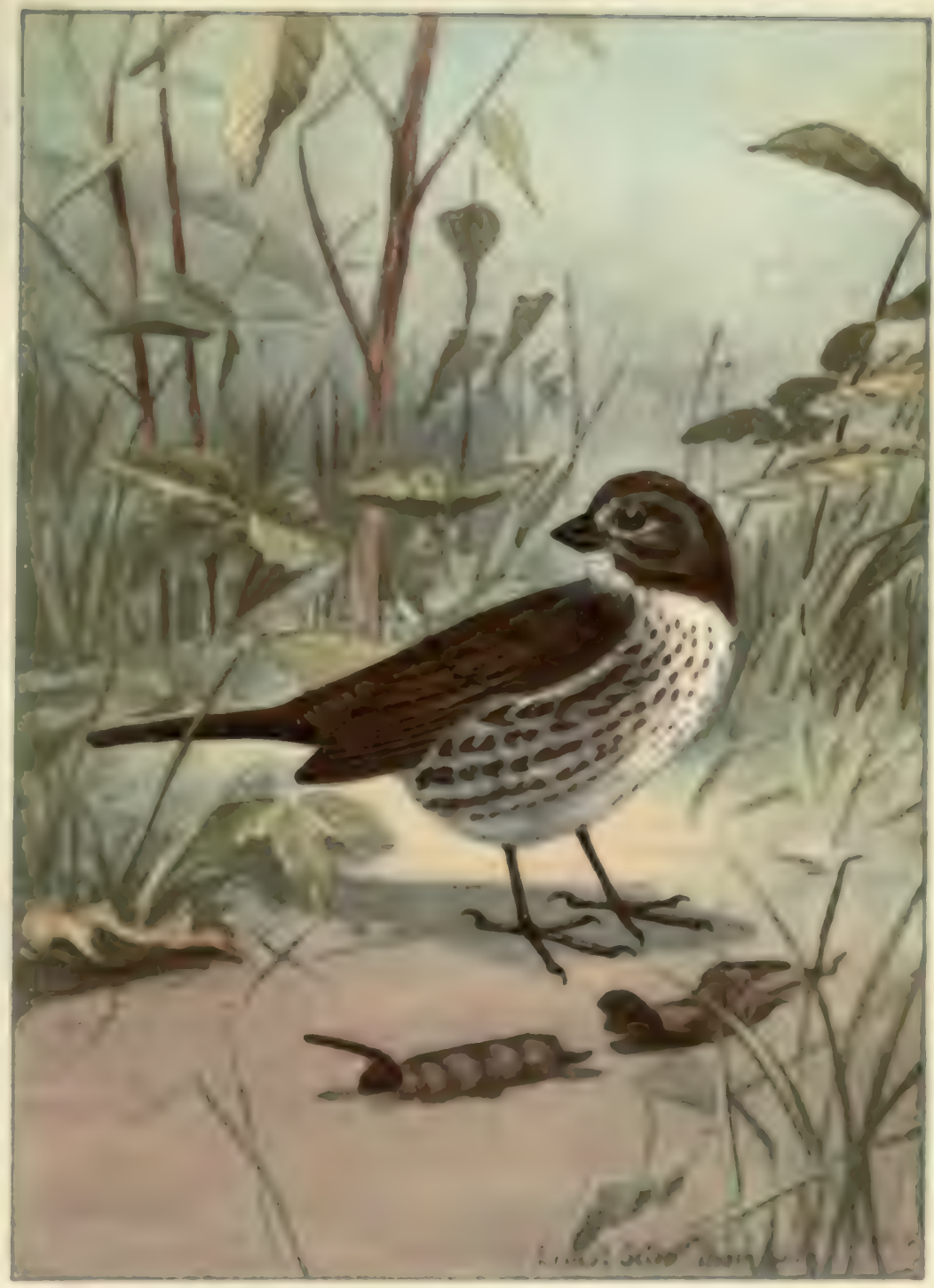

Рнат XIVI.

PaON 146.

POX SPARBOW.

Length, 7.25 Inchen. Tpper parts winge, and call bright reddtab brown: beck and hred mlsed with orowner color: under parts whlto and bright redilish brown. 

impressed with the Cruw's eleqquence you must hear him when, in the funcied privacy of his own flock or family, he discusses the affairs of the day. His notes then are low, and so raried in tone that one can not donbt their conversational character.

During the winter Crowe aswemble in lange flocks contuining many thousand individuals, who nightly neturn to some roost, which perlaps has been frequented for years. In March they leegin to pair and the nest is constructed eurly in $\mathbf{A}$ pril. It is a bulky affair of sticks, lined chiefly with graperine lark, and is placed in a tree, usually about thirty feet from the ground. The four to six eggs are bluish green, thickly marked with shades of brown.

Crows share with Hawks the reputation of being harmful birds. That they do much damage in the cornfield is undeniable, but, after the examination of nine hundred Crows' stomachs, Dr. Merrian, of the Depart. ment of Agriculture, stites that the amount of good done by the Crow in destroying grasehoppen, May beetles, cutworms, and other injurious insects, exceeds the lose caused by the destruction of corn. Moreorer, if the corn be tarred hefore planting, the Crows will not touch either the kernel or young sprout. The corn should finst he soaked in water overnight, and then placed in a ressel containing enough soft tur to cont earh kernel. It should then be rolled in plaster of Paris or wood ahles, so that it can be more easily handled."

The Blue Jay, in his uniform of blue and white, is so brightly colored, so large (he is nearly twelve inches in length), and often so noisy, that every one knews lim.

- See Barrnws and Shwarz. The Common Crow, Mulietin Ni G, Inited Sintes Departwebt of Agriculture, Division of Uraitbelong and Mammalogy. 
Liko the Crow, he is with us throughout the year. During the summer he is not very common, and is remarkably quiet, but in September and Octo-

Blue Jey, Cyanooitta cristata. ber migrants arrive from the North, and the birds are then abundant in bands. These bands roam about the country like a lot of schoolboys out chestnutting, pausing wherever they find acorns and chestnuts abundant, or leaving their feast to worry some poor $\mathrm{Owl}$ whose hiding place they have discovered.

The Blue Jay's best friend could not conscientiously call him a songster, but as a conversationalist he rivals the Crow. I have yet to discover a limit to his rocabulary, and, although on principle one may ascribe almost any strange call to the Blue Jay, it is well to withhold judgment until his loud, harsh jay! jay! betrays the caller's identity. Not content with a language of his orvn, he borrows from other birds, mimicking their calls so closely that the birds themselves are deceived. The Red-shouldered, Red-tail, and Sparrow Hawks are the species whose notes he imitates most often.

The Blue Jay nests in the latter part of May, building a compact nest of rootlets in a tree ten to twenty feet from the ground. The eggs are pale olive-green or brownish ashy, rather thickly marked with varying shades of cinnamon-brown.

Ortoles, BlackBirds, etc. (FAMILY ICTERID A.)

The popular naines of many of our birds were given them by the early colonists because of their fancied resemblance to some Old World species. The fact that some of these names are incorrect and misleading has been pointed out scores of times, but they are now as firmly fixed as the signs of the zodiac. 


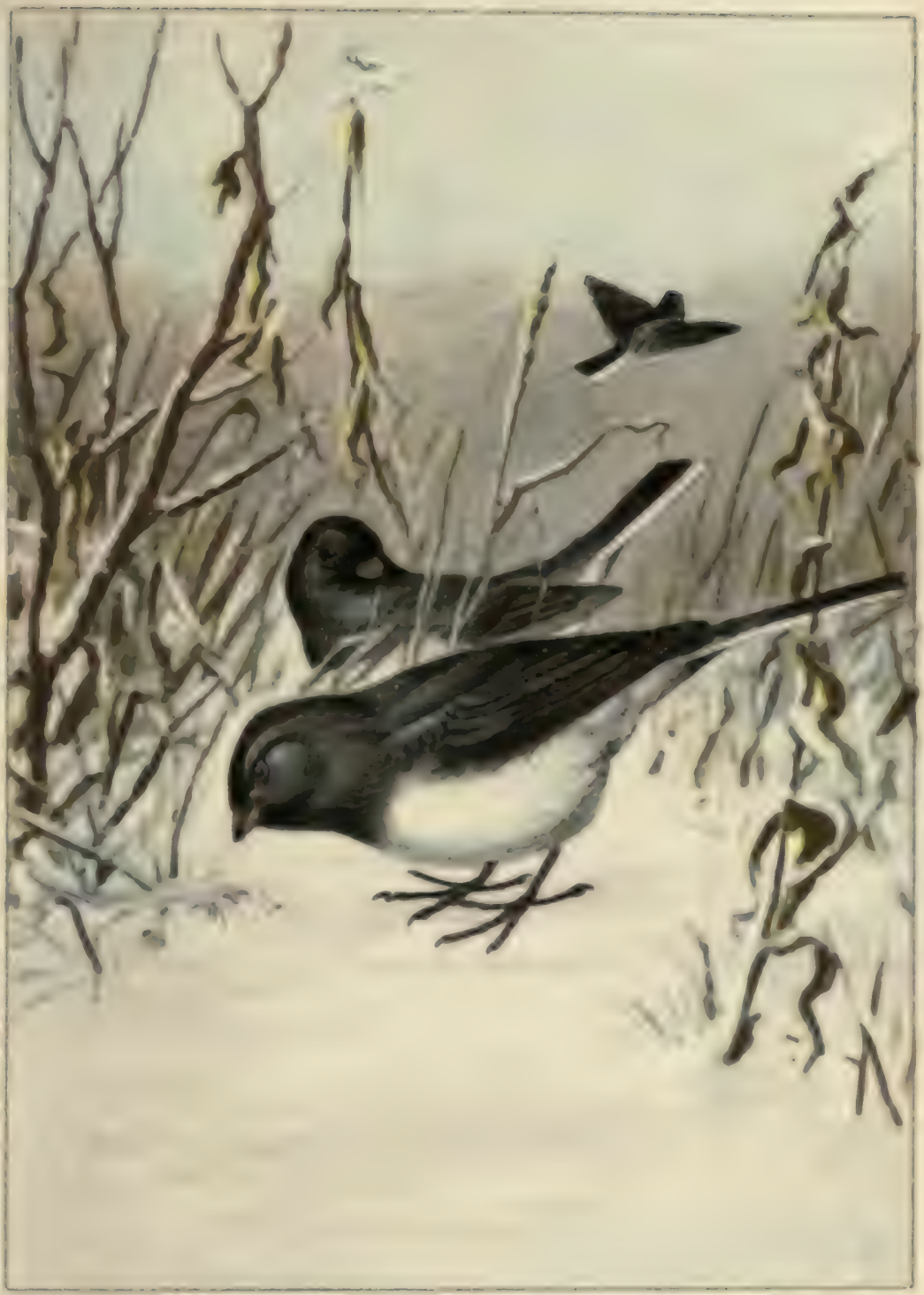

PLAT XIVII.

Psor 145.

JUNCO.

Length, 6.25 Inches Male, upper parts, throat, and bresat elate-oolor: belly and outer tall-feathers white. Fomale, atmillar, but plumage moro or lees waibed with browniab. 

Thus the Robin is not a Robin but a true Thruah, the Meadowlark is not a Tark but n Sturling, and the Orioles are not Orioles at all, but memilens of a distinar tively Amerien faunily havieng no representatives is the Old World. This family ooutains one lunulrol und fifty speries, of whieh nearly one thint helong in the genus Herme. The presailing colors of the binls of this genus are anange and black, hence their nsarmilanee to the true Orioles (gonus Orialua) of the Old Worlul.

Our baltimone Orible is a worthy representative of a group renarkable for its light colons. It is to these Eastimore ortab, sune colon that the liril owes nut only

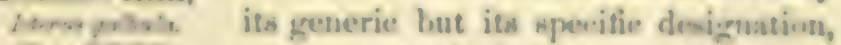
Fate ixxr. onage and black being the livery of Juml Jaltinume, after whom the lind was named.

The Thattimore Oriole, or, ns it is almo calles, Firelini, Goiden Robin, or llangneat, winters in Central America, and in the spring reaches the hatitule of Now York eity alout May 1. I always look for it when the elierry trees bunt into blosesom, and at no other time dons its beantiful plunuage appreur to incter alvantage shan when seen atrinat a background of white flowers. To the charn of leauty it adds the attmetion of song, a rich, ringing whistle, which enn be mare or less sucesefully imitater, when the bird immediatedy responda, clatlenging the supyosed trespuserer on lis domain.

The Paltimore's nest is a lag about five inehes deep and three inches in diameter, woven of plant-filwen, thresul, etr., and suspren leal from the terminal portion of a limbl, generally of an elm tree. The four to six egrs, are white, singnlarly s.rowled with fine blaek lines, and with a few sputes or blecehos.

The Oreland Orime is neither mo eomman nor mo gayly dresesel as his brilliantly colinod relatives nnd, being fonder of orchards than lawns and elm-shated highwass. 
is not so well known. The female is especially easy to overlook, her suit of plain olive-green closely harmonizOrohard Oriole, ing with the leaves in color. Young Icterus spurius. males at first exactly resemble her, but

Plate XXXVI. the following spring return, wearing their father's black cravat. In this plumage they might readily be taken for another species, so little do they resemble their parents in appearance. The adult chestnut and black plumage is not fully acquired until the second, or perhaps even the third spring.

The Orchard Oriole winters in Central America, and in the summer is found throughout the eastern United States from the Gulf of Mexico to Massachusetts. It arrives from the South about May 1, and is one of the firet birds to leave in the fall, rarely, being seen after September 1. Nesting is begun late in May. The nest is pensile, but not so deep as that of the Baltimore Oriole, having more the proportions of a Vireo's nest. It is composed entirely of freshly dried greenish grasses, and is suspended from near the extremity of a branch at a height of fifteen to twenty feet. The three to five eggs are bluish white, spotted, blotched, and scrawled with black.

The song of the Orchard Oriole resembles that of his orange-and-black cousin, but is far richer in tone and more finished in character.

The male Redwing, with his black uniform and scarlet epaulets, is a familiar inhabitant of our marshes, but Bod-winged Blaokbird, many who know him are not acquainted Ageluius phaniceus. with his very differently attired mate. She wears a costume which above is black streaked with buff and rust-color, and below is striped dingy black and white, and is much more retiring than her conspicuous husband. Her place is low in the bushes or among the reeds near the nest with its pale 


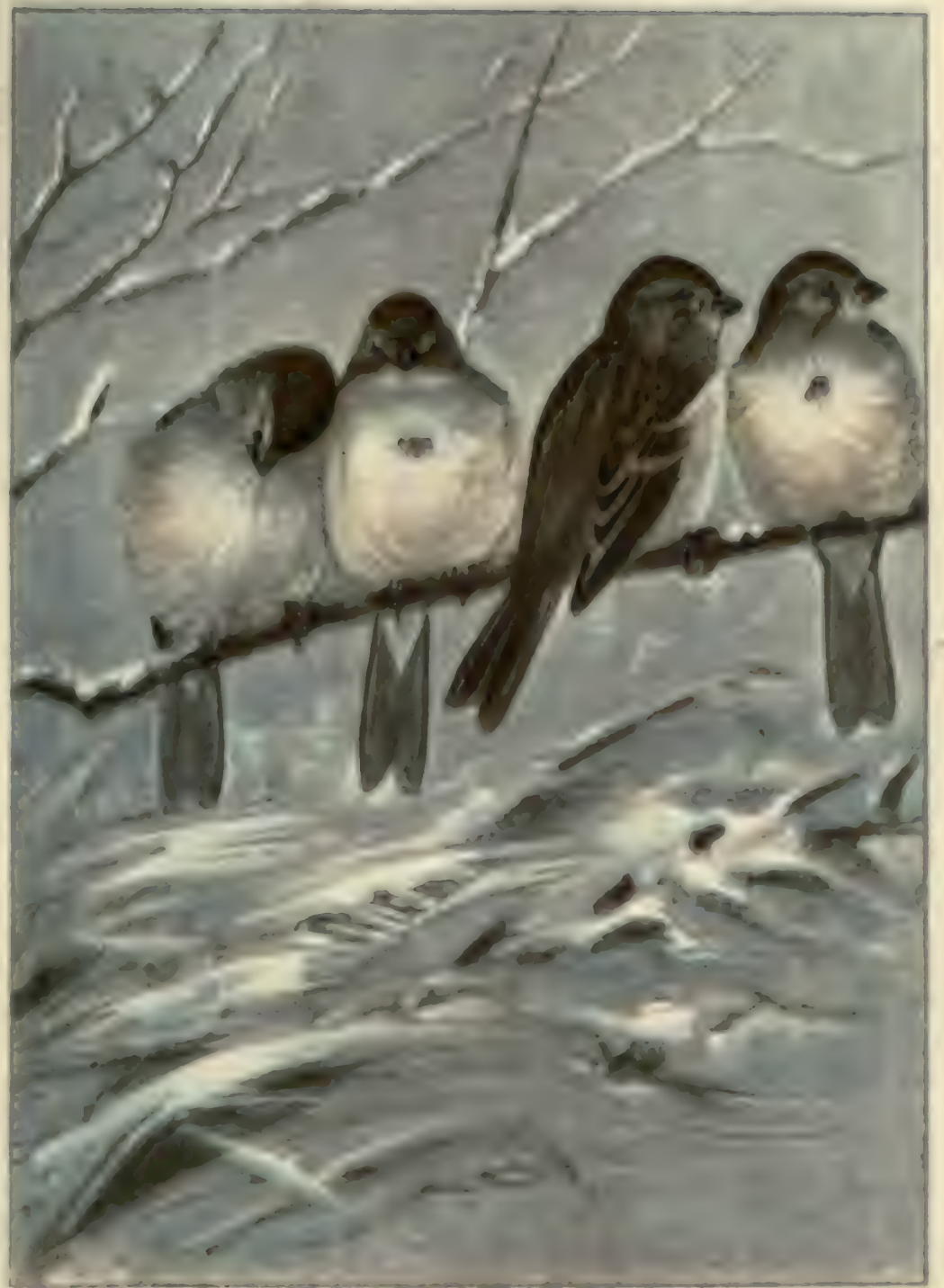

Prate XIIX.

PaOr INa

TREE BPARBOW.

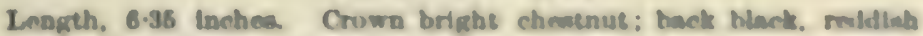
brown. sad bufty: under partu graylah: whes wabed wich browededs: a blacklsh spot to the oenter of the brenst. 

blue eggs, as singulerly scruwled with black. Ilo perches on the topmust linush of a neighlnoring tree, and douls. less supposes he is gnarding his home below, when is truth he is alvertising his treukure to every passer-by.

The Re.Jwing's liquid kieng-quir red is pleanantly anggentive of mashy places, but it is his early apring music for which we should ehiefly value him. The firse Rotins or Bluebirds are somewhat unrelialile signe of eppring. They are such hasiy binds that it reguires very little encouragenent from a fel,ruary sun to send a few skimishers northward. Wo can not to sure whether they represent the alvance guand or are individunls who have had the counge to winter with un. But when early in March the Redwings come. then we know that the tide of the year has turned. With perennial faich in the season they come in flocks of hundreils singing their springtime chorus with a spirit that March witads can nopt subdue.

About the time the Redwings come, late in Fobruary or early in March, we may expert the Purple Grackles Perple Cnokve, or Crow Blacklirds. They migmate in

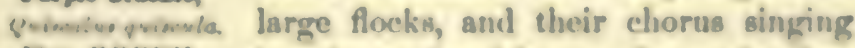

Mate XXXVII. is quite as inspiring as the springtime encerts of the Redwing. There are two kinds of Crow Blackbirds, known as the Purple Grackle and the Bronned Grackle. The former has iridewent hars on the tack and in the Northern States is found only east of the Alleghnnies and south of Masaschusetts; the latter lans the lasck shining, brassy, bronze, without iridescence, and in the nesting geasm inhahita the country went of the Alleghnnies and north of Connertieut. The fermales of both species are smaller and duller than tho males.

Grackles are among the few of our land linis who live in flocks all the yeur. They pass the winter and migrate in larger companies, but when nesting ane in suallar 
bands or colonies. They generally select a pine grove, often choosing one in a cemetery, park, or other locality where they will not be disturbed. This may result in a scarcity of food when the young are born, but, rather than abandon a locality which experience has proved to be safe, they make long journeys in search of food for their nestlings. By watching the old birds one may then easily learn where they live. Their flight is direct and somewhat labored, and when going only a short distance they "keel" their tail-feathers, folding them upward from the middle, an action which renders Grackles conspicuous and easily identifiable when on the wing. On the ground they strut about with a peculiar walk, which, in connection with their yellowish white eye, adds to the singularity of their appearance.

The Grackle's nest is a bulky, compact structure of luud and grasses. It is usually placed in trees, twenty to thirty feet from the ground, but the bird may sometimes nest in bushes or even in a Woodpecker's deserted hole. The three to six eggs are generally pale bluish green, strikingly spotted, blotched, or scrawled with brown and black. But one brood is raised, and when the young leave the nest they roam about the country in small bands, which later join together, forming the enormous flocks of these birds we see in the fall.

The Bobolink's extended journeys and quite different costumes have given him many aliases. Throughout his breeding range, from New Jersey to Nova Scotia, Bobolink, and westward to Utah, he is known
wolichonyx oryzivorus. July nesting as the Bobolink. In
Plate XXXVIII. buff, and white werding dress, and gains a new suit of feathers resembling in color those worn by his matc, though somewhat yellower. This is the Reedbird dress, and in it he journeys nearly four 


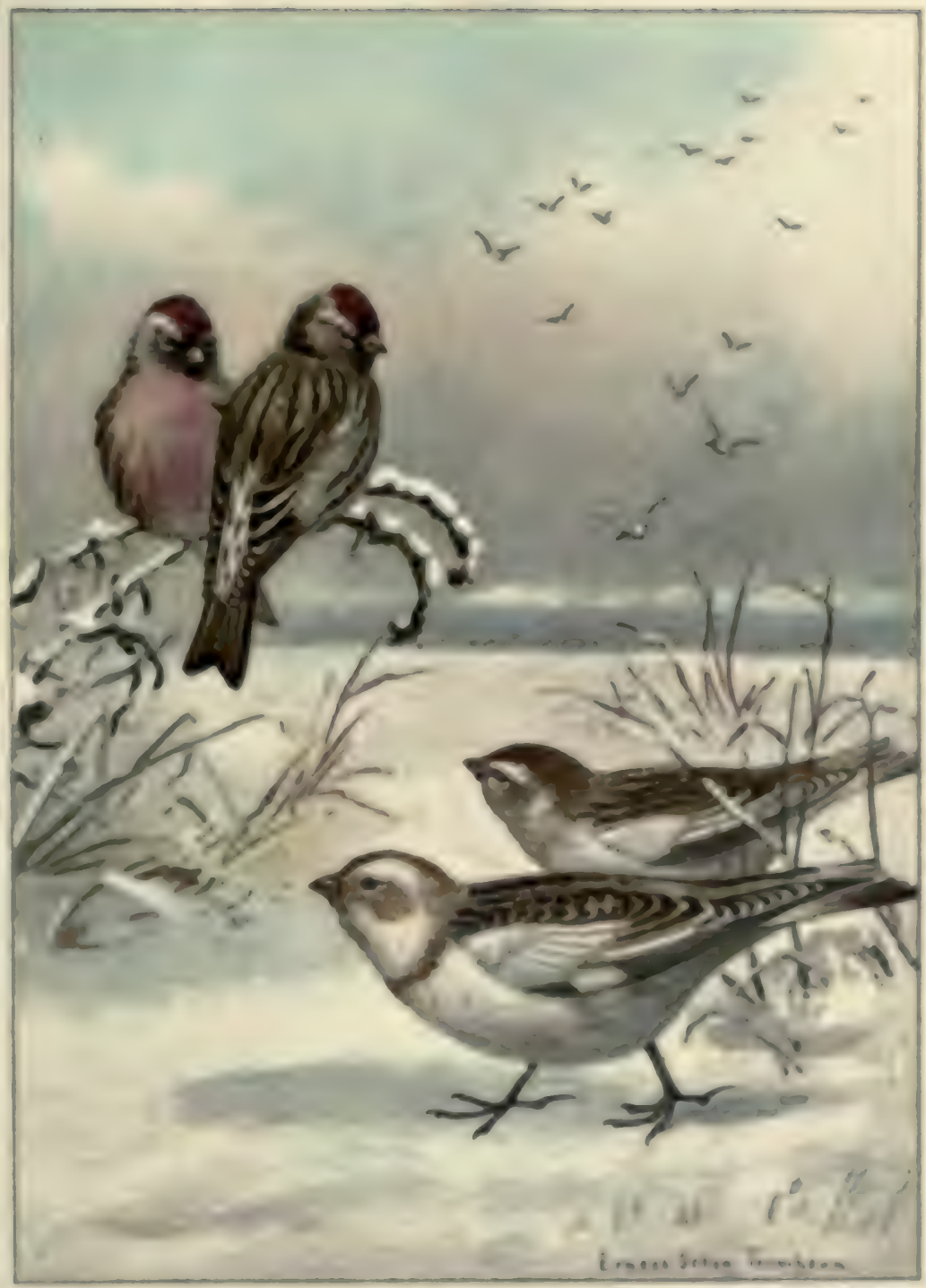

Puate L.

REDTOL.

Paom 24. 148.

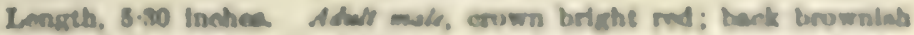

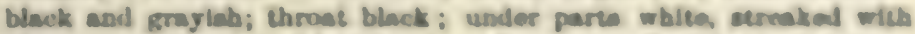

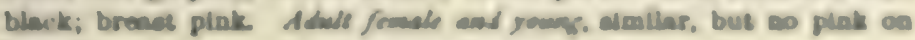
broat.

\section{ANOWTLAKR}

Lancth, 6-90 Iachen Opper parta brown and Mlack: whas aed call bleck and whlto; under parts whise; orenet and aldes browniab. 

thousund miles to his winter gaurters south of the Ama. $20 n$.

The start is male in July, when lie juins flochs of his kind in the northern will-rice (Zisania aysution) uar-hess. Tate in Auguat he visite the cultivated rive fields of South Carolina and Georgia, and it is at this seas. son we so of ten hear the metallie tink of passing mignants. The rice is now in the milk, and the Ricolinis, or Orts. lans, as they are called in the South, are so destructive to the crop that it is entimated they directly or indirectly cause an annual luse of $\$: 3,000,000$. Some lirds linger as fur north as New York until October 1, but by this time the lesulens of the south-lound host have resehend Cular, where they are called Chambergo. From Cuba they pass to the coast of Yucatan, and thence soutliwar] through Central America or to the island of Jamaien, where, beranse of their extreme fatness, they are known as Butterhirls. From Jamaiea they go to the muinlaud, either of Centmal America, or by one contisusous flight of four hundrod miles to northen South America, thence traveling routhwand to their winter bouse.

The northward journey is legun in Mareh or April, and about the 2ith of the latter month the ranguan reaches Florida. It is composed only of males, now callea Maylirida, all in full song. Let any one who knows the Polnolink's song imagine, if lie ent. the effect produced loy three humdreil hirds singing together!

About May 1 Botwolinks reach the vicinity of New lork eity. The females sown follow the males, and early in June the lirids are nesting. This is the glad menson of the Bobolink's year. For ten months he luss leen an exile, lut at last he is nt home agnin, amb lio gires roice to his joy in the jolliest tinkling, ripp?ing. rollieking song that ever isened from birl's t?

In the fielda made werry ly the musie of bolnolinks one 
is almost sure to find Meadowlarks. They are strong. legreil walkers, and spend all their time while feeding Meadowlark, on the ground. Like all terrestrial, Sturnells mayna. protectively colorel birds, they often

Plate $\Sigma x \mathrm{xIX}$. try to escape observation by liding in the grasses rather than by flying. When perched in a tree or other exposed position, they are among the shyest of our smaller birds, rarely permitting a near approach; but when they fancy themselves concealed on the ground they sometimes "lie as close" as Bob-whites. When flushed they fly rapidly, alternately flapping and sailing, showing as they fly the white feathers on either side of their tail. These feathers are the Meadowlark's best field character. They are very conspicuous when he is on the wing, and, when perching, if he is alarmed or excited, he exposes them by nervously flitting or twitching his tail. This morement is generally accompanied by a single nasal call-note, which changes to a rolling twitter as the bird takes wing. Neither of these notes gire any indication of the sweetness of the bird's song, a high musical whistle, clear as the note of a fife, sweet as the tone of a flute. It is subject to much variation both individual and local, but the song I oftenest hear in northern New Jersey may be written :

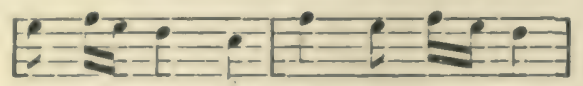

When singing, the birds usually perch in an exposed position, generally choosing the topmost branches of a tree or a dead limb.

The Meadowlark's nest is placed upon the ground, as a rule, in a tuft of grasses which is arrange:l to form a dome over it. The eggss, fonr to six in number, are laid about May 15, and in co'or are white, spotted or speckled with cinnamon or reddish brown. 


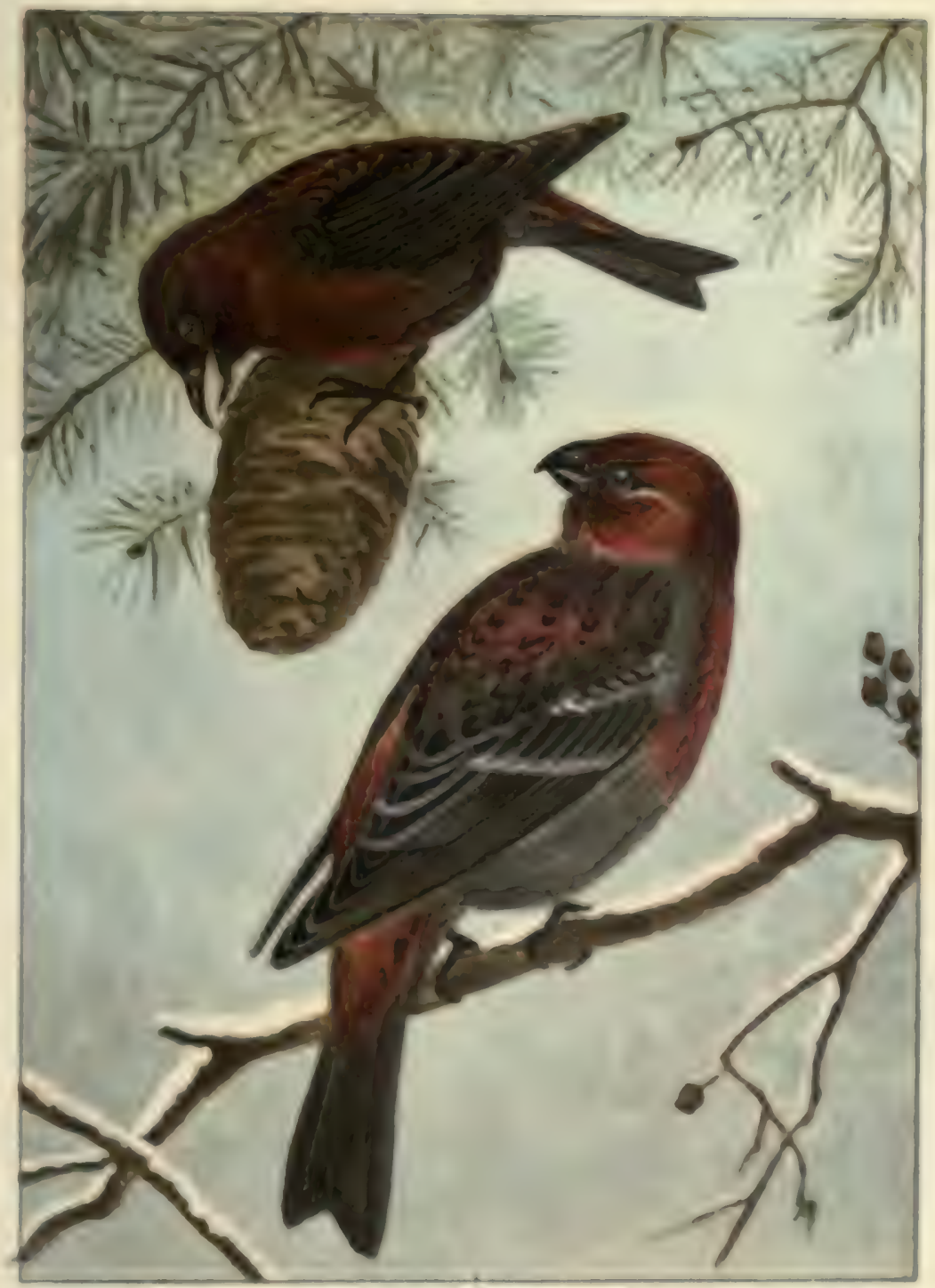

Prate LI.

\section{AMERICAN CROGSRILL.}

Pane 147, 148.

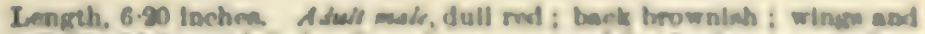

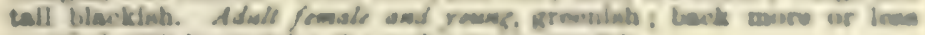

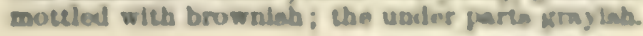

\section{PINE CItOSTIEAR.}

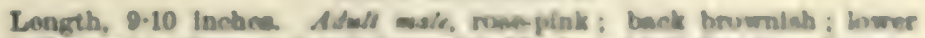

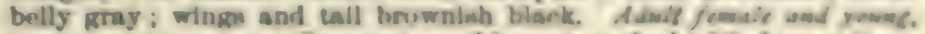
kray, crown, uppor call-oureren, and breas wadbund with deop yedirow. 

Occasionally Cowbirds are scen during the winter near New York eity; but, as a rule, they retire farther

Cowbird,

Molushrus ator.

Plute XL.

south at this serson, and are first ob. served there in the spring about March

2). They do not come in large flocks, but singly or in small bands. The male may now be seen perched in an exposed position on a treetop, calling his long-drawn-out, glassy kluck, tsè-e-e-e. Later, when wooing the fcmale, he utters a curions, gurgling note, resernbling the sound made by polving water rapidly from a bottle, and accompanying it by motions which suggest extreme nausea. We often see these birds feeding near cattle in the pastures, always in small flocks, for they do not pair nor even construct a nest, the female laying her egg in the nest of another and generally smaller species. Few birds seem aware of the imposture, and not only do they incubate the erg but they may attend to the demands of the young Cowbird at the expense of their own offspring, who sometimes die of starvation. Even after leaving the nest the young parasite continues its call for food, and when seeing a Maryland Yellowthroat, or some other small bird feeding a clumsy fledgling twice its size, one wonders it does not detect the deception. The better we know birds the more strongly are we impressed with their individuality. To one who has no friends in fenthers it seems pure fancy to endow rome insignificant "Chippy" with human attributes; but in reality there are as clearly defined characters among hirds as among men. To be convinced of the trutb of this statement we have only to compare the Cowbird, a thoroughly contemptilile creature, lacking in every noral and maternal instinct, with the bird who constructs a well. made nest, faithfully broods her eggs, and cares for her young with a devotion of which mother lore alone is capable. 


\section{Sparrows, Finches, etC. (Family Fringillid $x$.)}

This, the largest family of birds, contains between five hundred and fifty and six hundred species, and is represented in all parts of the world except the Australian region. Sparrows are the evergreens among birds. When the leaves have fallen from the chestnut, oak, and maple, the hemlock, pine, and cedar are doubly dear. So, when the Flycatchers, Warblers, and Thrushes have left us, the hardy Sparrows are more than usually weleome. Feeding largely on seeds, which their strong, stout bills are especially fitted to crush, they are not affected by the changes in temperature which govern the movements of strictly insectivorous birds.

Some species are with us throughout the year, some come from the South in early spring and remain until snow falls, others come from the far North to pass the winter; so that at no season of the year are we without numbers of these cheery birds. Fortunately, some of our best songsters are members of this family. Their music is less emotional than that of the Thrushes, but it has a happier ring - the music for every day.

It is the Song Sparrow who in February opens the song sparrow, season of song. and it is the Song Meloepiza fusciata. Sparrow who in November sings its Plate XLI. closing notes; nor, except during a part of August, has his voice once been missing from the choir.

His modest chant always suggests good cheer and contentment, but heard in silent February it seems the divinest bird lay to which mortal ever listened. The magie of his voice bridges the cold months of early spring; as we listen to him the brown fields seem green, flowers bloom, and the bare branches become clad with softly rustling leaves. 


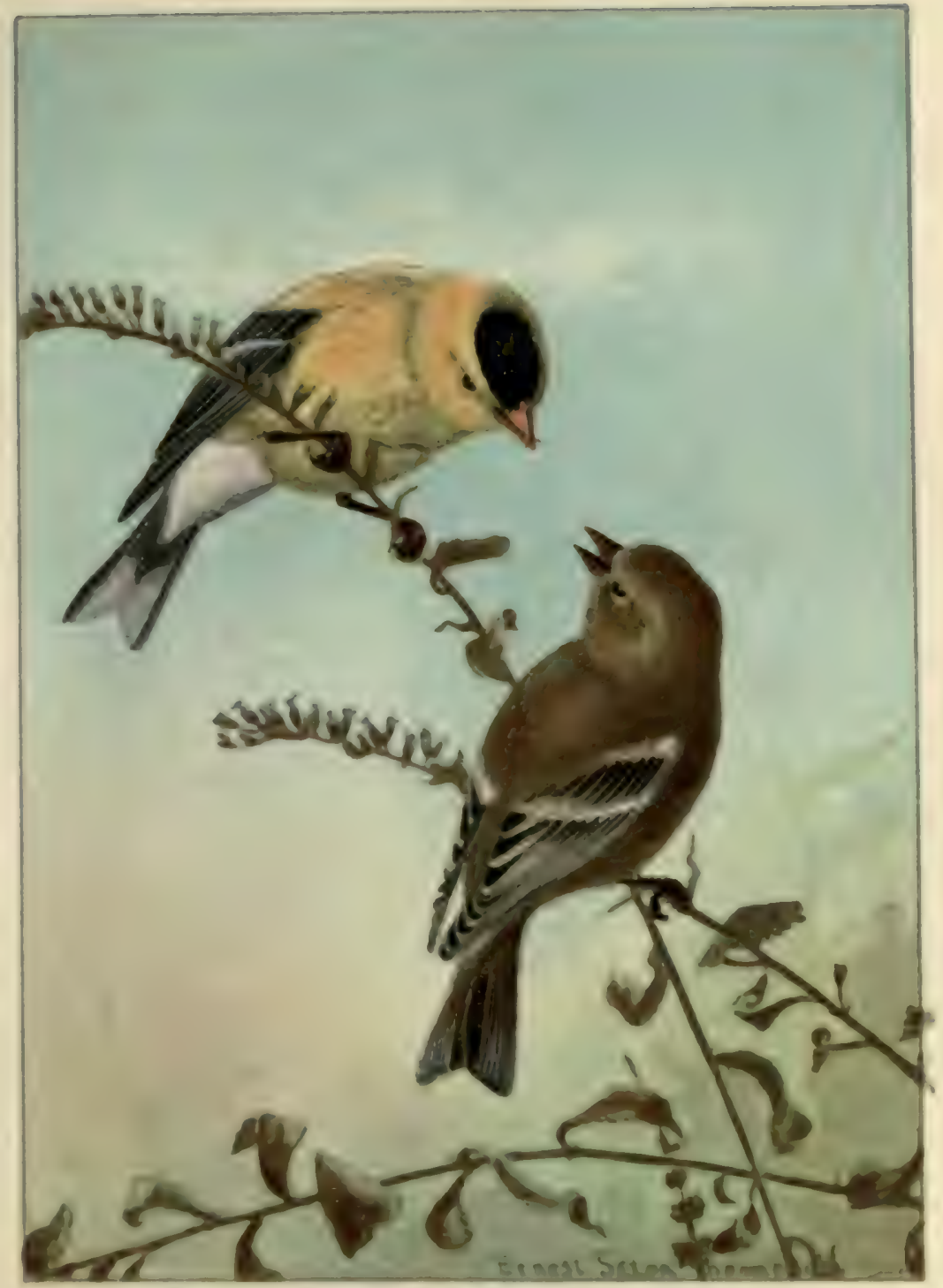

Pruxe LIT.

Paan 148.

\section{AMRRIOAN GOLDFINCH.}

Length, $5 \cdot 10$ Inches Adwlt male in summor, erown black; reat of body yellow; whings and tall black and white. Adrelt female and males in zoineor, upper perts graylsh brown; crown yellowlah; under parts solled whitiah; throat yellow. 

You ean not go far afield without meeting this singer. He is not only our commonest Sparrow, but one of our commonest birds. Gencrally you will find him on or near the ground at the border of some undergrowth, and if there be water near by, preferably a meadow brook, his presence is assured. When flushed he will doubtless make for the nearest thicket, "pumping" his tail, as Thompenn expressively says, in descriling his somewhat jerky flight. Now he questions you with a mildly impatient chimp or trink, a call-note not to be mistaken for that of any other species, when once you have learned it. Equally diagnostic is the bird's spotted brenst with one larger spot in its center.

The Song Sparrow's nest is usually placed on the ground, but sometimes a bush may be chosen for a nest. ing site. The ergns, four or fire in number, are bluisl: white, thickly marked with reldish brown. The Song Sparrow rears three broods each year, the nesting season lasting from May to August.

The Swamp Sparrow, a well-named cousin of the Song Sparrow, resembles his relative in his fondness for

Swamp 8parrow, Yelooprase georginna.

Plate Xi.II. the ricinity of water and halit of taking refuge in low cover. He is a true manh or swamp bird, and is particularly alundant in large marshes. His call is an insignificant cheep, while his song is a simple, sweet, but rather monotonous theet-tinet-tineet, repeated many times and cecasionally muning into a trill.

The Swamp Sparrow nests from northern Illinois and Penneylvania northward to Labrador. Its nest and eggs resemble those of the Song Sparrow. It is migratory in the northern part of the range, and is rare in winter north of southern New Jersey.

Both the Song and Swanp Sparrow are, as we have seen, birils of the lowlands, though the latter also inlsab- 
its higher ground, but the two Sparrows now to be mentioned are birds of the uplands, rarely if ever living in low, wet places.

An old hillside pasture, dotted with young cedars or elumps of bushes, in which he may place his nest, is the

Field Jparrow, favorite home of the Field Sparrow.

spizellu pusilla. Here you may look for him early in

Plate XLIII. April. He is a rather shy bird, who will fly some distance when alarmed, and then alight on a bare twig near or at the top of some bush or sapling. Very different this from the Song Sparrow's way of diving into a bush.

From his exposed position he watches you and gives you an equally good chance to watch him. Note the whitish, unstreaked breast, the reddish brown or sorrel crown, the gray face and whitish ring about the eye, and especially the pale brownish or flesh-colored bill. These are all good marks, and if now you can hear him sing his identity will be settled without question. His song is one of the most pleasing I know. It is very simple but very expressive, a siveet, plaintive cher-wee, cher-wee, cher-wee, cheeo dee-e-e-e-e, which goes straight to one's heart. It is sung most freely after sunset, and is in keeping with the peacefulness of the evening hour. At this time, too, the bird seems inspired to more than usual effort, and its ordinary song is often so elaborated and prolonged as to be scarcely recognizable.

The song season ends in the latter part of August, and, although the birds are with us until November, I have rarely heard them sing in the fall.

The Vesper Sparrow, Grass Finch, or Bay-winged Bunting-for he bears all three names-prefers more open grounds than the Field Sparrow selects. There is something free and spirited about this hird and its song which demands space for its proper development. No 


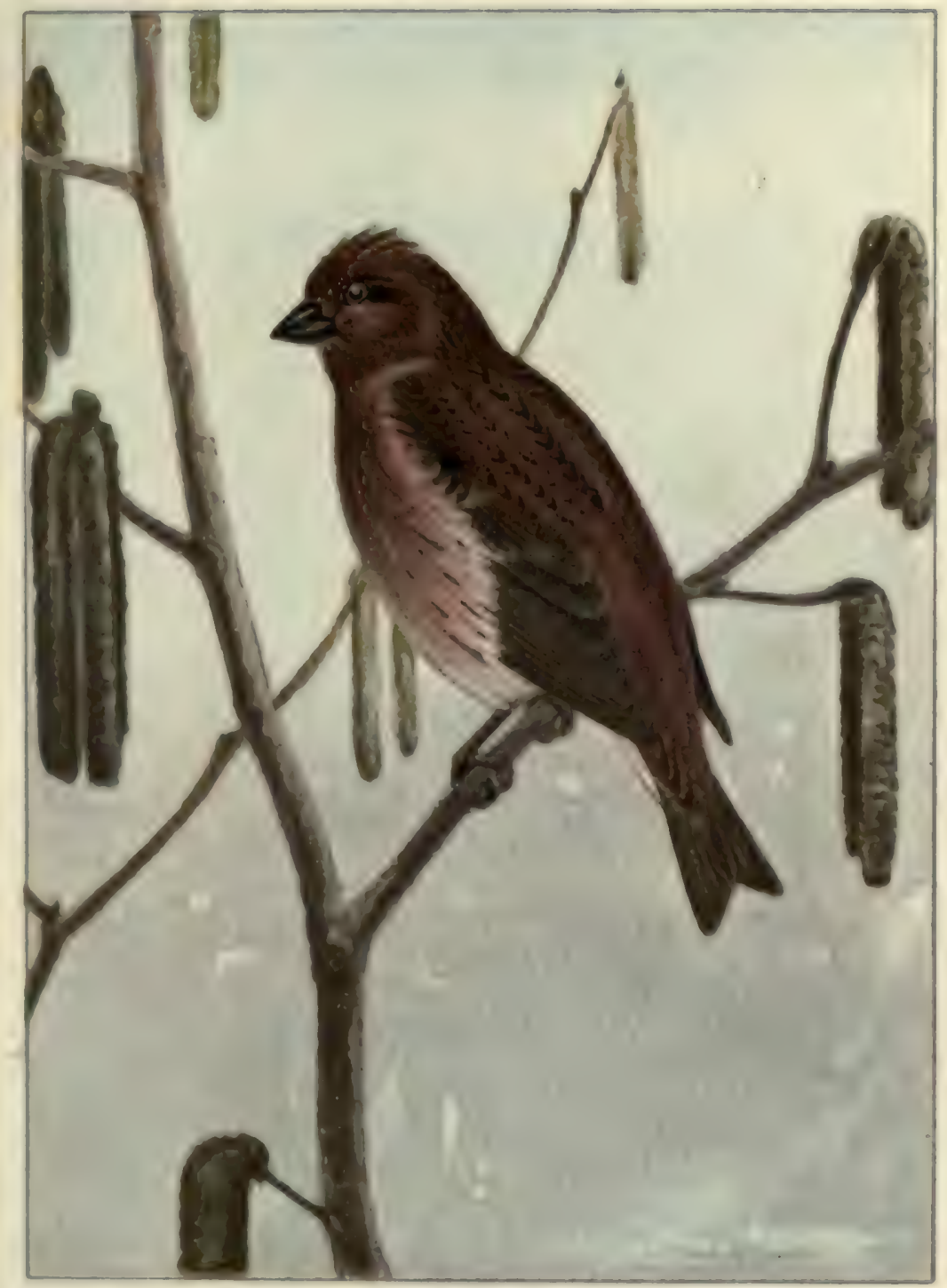

Prats LIII.

PAOR 149.

PURPLE FINCE.

Length, 6-20 lochen Aduls male, rose-pink; back brownish; lower belly white: no white in winga. Aduli female and young, upper parts streaked browniah and graylah; ander parts white, streaked with brownish; bill rounded on top; a tuft of bristly feathers ovar the noetrila. 

swamp or thicket wi!l do for him, but in grent broad fields he is at home. If a roadway leads through his haunts,

Venper sparrow, you may often see him on the ground Pucuen gramineme. ahead of you, and when he flies the Plute XLIV. white feathers shown on either side of his tail will give you an excellent clew to his identity. Probably he will fly on ahead a little way and alight again in the road, or a longer flight may lead him to a neighboring fence or the upper branches of a more distant tree. It is from positions of this kind that he most often sings. With him song is evidently a matter of importance. He can not, like many birds, sing between the mouthfuls of a meal, but ascending to his perch he gires perhaps half an hour entirely to music, resting motionless between the interrals of each song.

It is impossible to satisfactorily describe this song. It resembles that of the Song Sparrow, but is finer and willer. It opens with one low note, followed by two higher ones, while the Song Sparrow begins with three notes, all of the same kind.

The Vesper Sparrow is migratory, coming to us with the Field Sparrow early in April and remaining until Noremher. Its nest is placed on the ground, and the bluish or pinkish white speckled eggs are laid early in May.

It is strange, is it not, that the only bird we all detest sliould also be the only one who insists on sharing our homes with us. The House or English Hoase Bparrew,

Rueur domesticus. Sparrow, is a product of the times; a remarkably keen-witted bird, who, like a noxinus weel. thrives and increases where a less hardy speries conld not exist.

This harsh-roiced little gamin soon detects and aroids anything like a systematic attempt to entrap him, and, being productive past all belief, seems likely to completely 
overrun the land. He was introduced into this country in 1851 , and in 1870 was found only in the cities of the Atlantic States. Now he has spread over the greater part of the United States and Canada.

If he were restricted to the cities we should have only his never-ceasing, maddening chatter and our soiled walls to complain of ; but he lias invaded not only the towns and villages and the neighboring houses, but visits also our grain fields and fruit orchards, our woods and marshes. No effective method for his externination has been devised, and I fear we must accept the Sparrow as a penalty for the shortsightedness and ignorance which permitted us to meddle with the laws of Nature.

If we except this ever-present nuisance the Chippy is the most domestic of our Sparrows. He seems thorChipping sparrow, oughly at home about our doorsteps; a Spizella socialis. contented, modest little bird who apPlate XLV.

parently tries hard to believe in the goodness of human nature, even though he meets with but little encouragement. One wonders why he has not long ago given up the attempt to make friends with us, so rarely do we show any appreciation of his advances. The house cat is Chippy's chief enemy. Crouching and crawling, waiting and watching, she misses no opportunity to pounce on an unsuspecting bird. It is surprising that any escape. But each spring, about $\Lambda$ pril 10 , the Chippy comes back to us after a winter in the cotton, corn, and broom-sedge fields of the South, and soon we hear his unpretentious, monotonous chippy-chippy-chippy, many times repeated, and occasionally running into a grasshopperlike trill.

About a month later we may find further evidence of lis too often misplaced trust in a neat, hair-lined nest built in the vines on the veranda or a neighboring tree. The eggs are unexpectedly pretty, a bright blue or bluish 


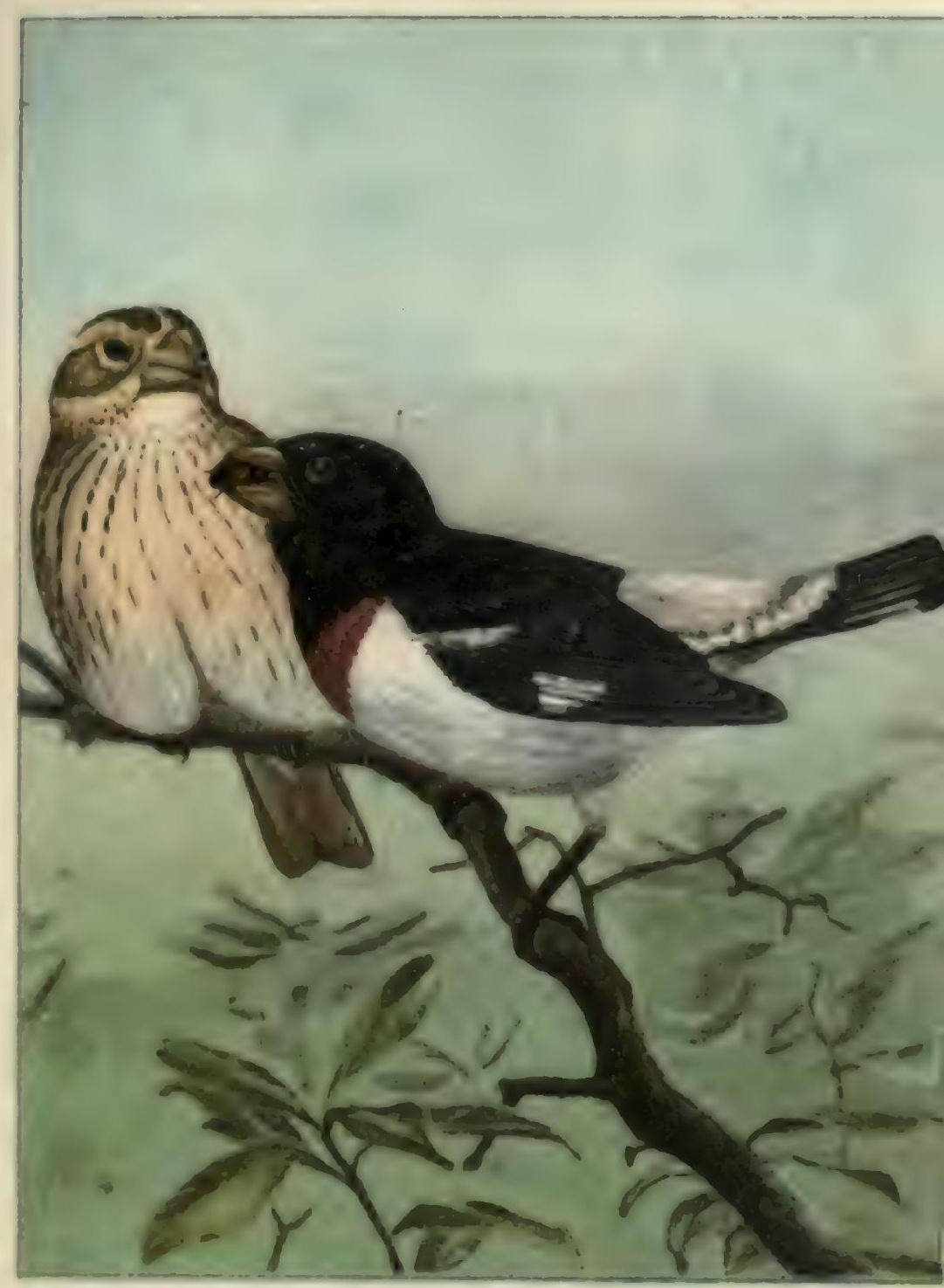

\section{Pнate IIV.}

PaAs 150.

\section{ROSE-BREASTED GROSBEAR.}

Longth, 8.10 Inchea. Adult male, crown and back black; ramp wilite; throat black; breast rose-red; belly white. Adwll female, upper parts dark brown and buff; a white line over eye; under parts bufty. streaked with browniah; under wing-ooverts ornnge. 

green, spotted, chiefly at the larger end, with cinnamon. brown or llackish markings.

Up to this time the Chippy has giren us a good opportunity to see his chestnut eap and black forehead, but when the nesting season is over he will change these for a cap to matchl his coat, and with others of his kind gather in old, weedy fields, remaining there until cold weather drives him southward.

Alout the time of the first frost a new Sparrow will appear in the hedgerows and thickets and the underWhita-throeted growth of the woods. The white patch sparrow, on his throat may aid in his identificaZonotrichis abbicolias. tion as the White-throated Sparrow, a Plate XLVI. Northern bird who in the summer nests from northern New England northward, and in winter is found from southern New England to the Gulf of Mexico.

He is disposed to be rather quiet for several days after his arrival, and, beyond a few low notes addressed to his companions, has little to say; but if you whistle to him even a poor imitation of his song, nearly every lir.d in the company will hop ug from the tangle of lranches and, perching on the outer twigs, look for the friends who called. Perhaps some may esay a tremulous re-ponse, but for a week or more they will make few attempts to sing. Later, you wiil hear the sweet, plaintive nures that give to this bird the name Peabody-bird.

The White-throat's call-notes are a low tseep and a very characteristic sharp chink, which has been well likened by Mr. Bicknell to the sound of a marble cutter's chisel. At this senson the White-throuts roost togrether in floseks of varying size, and if you chance to the near their home at hedtime you will hear this chink note given as a "quarrien' chorus." Finally, as the gloom deepens, it will renas, and from the dark depths of the 
thicket will come only the cozy, contented twitterings of the birds wishing one another good night.

The interest with which one examines a flock of Whitethroated Sparrows is intensified by the probability of White-crowned finding their distinguished relative the Zonotrichia sparrow, White-crown. In the Mississippi Valley he is often common, but in the leucophrys. Atlantic States he is sufficiently rare to be a character of importance.

The White-crown differs from the White-throat in having no white on the throat, which, like the breast, is gray, and in having the space before the eye black instead of yellow or white. In the fall his crown is brown, with a paler line through its center.

Near New York city I look for the White-crown in September and October, and again about May 15. Thompson describes its song as "like the latter half of the White-throat's familiar refrain, repeated a number of times with a peculiar sad cadence and in a clear, suft whistle."

Some fine day about the middle of March you may hear a song so unlike,any you have ever heard, that be-

Tox Sparrow,

Pusserella iliaca.

Plate XLVII. fore the singer ceases you will know you are on the verge of a discovery. The song is loud, exceedingly sweet, and varied. Its richness of tone seems to accentuate the bleakness of the bird's surroundings. It is a song for summer, not for leafless spring; but heard at this season it seems all the more attractive, and with pleasurable excitement you hasten toward the second growth, near the border of which the bird is perchel. His large size and bright reddish brown upper parts readily distinguish him from other Sparrows, and, in connection with his spotted breast, give him a general resemblance to a Hermit Thrush, for which bird he is sometimes mistaken; but a 


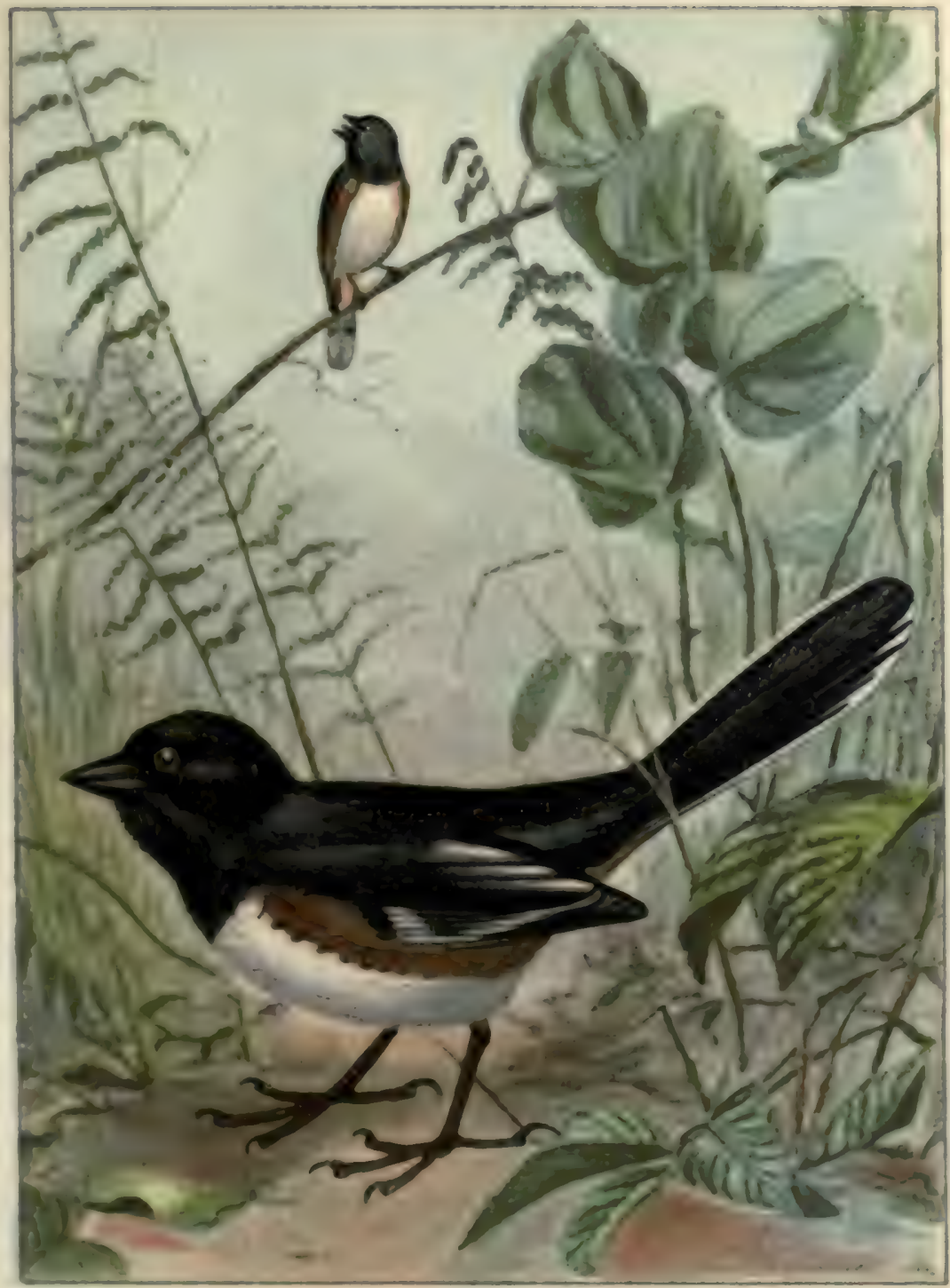

Puate LV.

TOWHJAR.

PAon 161.

Lenpth. N.3: Inchere Adult male, upper parts, throat, and breast hlack; boilg white; aldes reddloh brown. Adalt fomale, similar, but black replaced by browniah. 

glance at his short, stout bill at once shows his family relationships, and you should have no difficulty in identifying him as the Fox Sparrow.

A month later he will leave us for his summer home in the far Nortl, but in October and November his ringing notes may again be heard as he pauses a day or two on his journey southward.

After the Fox Sparrows go, our bird-life is reduced to its winter elements - that is, permanent residents and win-

\section{Janoo,}

Junce hyemalis.

Plate XI.VIII.

ter visitants. Of the latter the Junco or Slate-colored Snowbird is the commonest and most generally distributed. Although we call this bird a winter visitant, he is with us nearly eight months in the year, arriving late in September and remaining until early May.

The Junco is one of the birds whose acquaintance can be easily made. His suit of slaty gray, with its low-cut vest of white, is not worn by any other of our birds; and while some species show white onter tail-feathers in flight, the Junco's seem to be more than usually conspicuons.

Except when nesting, Juncos associate in loose flocks of from ten to fifty. Generally you will find them feeding on the ground near evergreens, into which, when disturbed, they will fly with a twittering note. If they are exrited hy your appearance you will hear a sharp, kissing call; but if unalarmed they will utter a rapidly repeated cherc-chere-chen, expressive of the utmost contentment. In March and $\Lambda$ pril, before leaving for their summer home in northern New England or the crests of the Alleghanies and Catskills, the Juncos sing a simple trill or low, twittering warlle. Moulest in manner and attire, there is nothing of esperial interest in the Junco's habits, and only bird-lovers can un.lerstand what a difference his presence makes in a winter landecape. It brings a sense of companionship; it is a link between us and Nature. 
The bird's cheery twitter is as welcome as a ray of sunlight on a cloudy day.

With the Juncos we may often find a company of Tree Sparrows or Winter Chippies. They resemble our

Tree sparrow, Spizella monticola.

Plate XLIX.

familiar Chipping Sparrow, but the blackish dot in the center of their breasts is a good distinguishing mark. Then, too, the true Chippies all leave for the South in November, while the Winter Chippies come in October and remain until April.

Tree Sparrows are sociable birds, with apparently the best of dispositions. They are usually found in small companies, each member of which seems to have something to say. Watch them feeding on an old weed stalk left uncovered by the snow. It bends beneath the weight of half a dozen birds, but, far from attempting to rob one another, they keep up a conversational chatter bespeaking the utmost good fellowship. Too-lā-it, too-lä-it, each one calls, and I have only to remember this note to bring clearly to mind a bright winter morning with the fresh snow crystals sparkling in the sunshine, and in the distance a tinkling chorus of Tree Sparrows at breakfast.

Another winter associate of the Junco's, and an intimate friend of the Tree Sparrow's, is the Redpoll, RedRedpoll, poll Linnet, or, as he is sometimes Acanthis linaria. $\quad$ called, Red-capped Chippy. The RedPlate L. poll nests in the far North, and the extent of his southern journeys depends very much upon the supply of food he finds in his winter wanderings. When there are seeds in abundance north of the United States, we do not see many of these birds, but if the larder fails they may come into New England in great numbers, and a few may venture as far south as Virginia. One can not tell, therefore, when to expect them, but it is well to be on the lookout from November to March. 


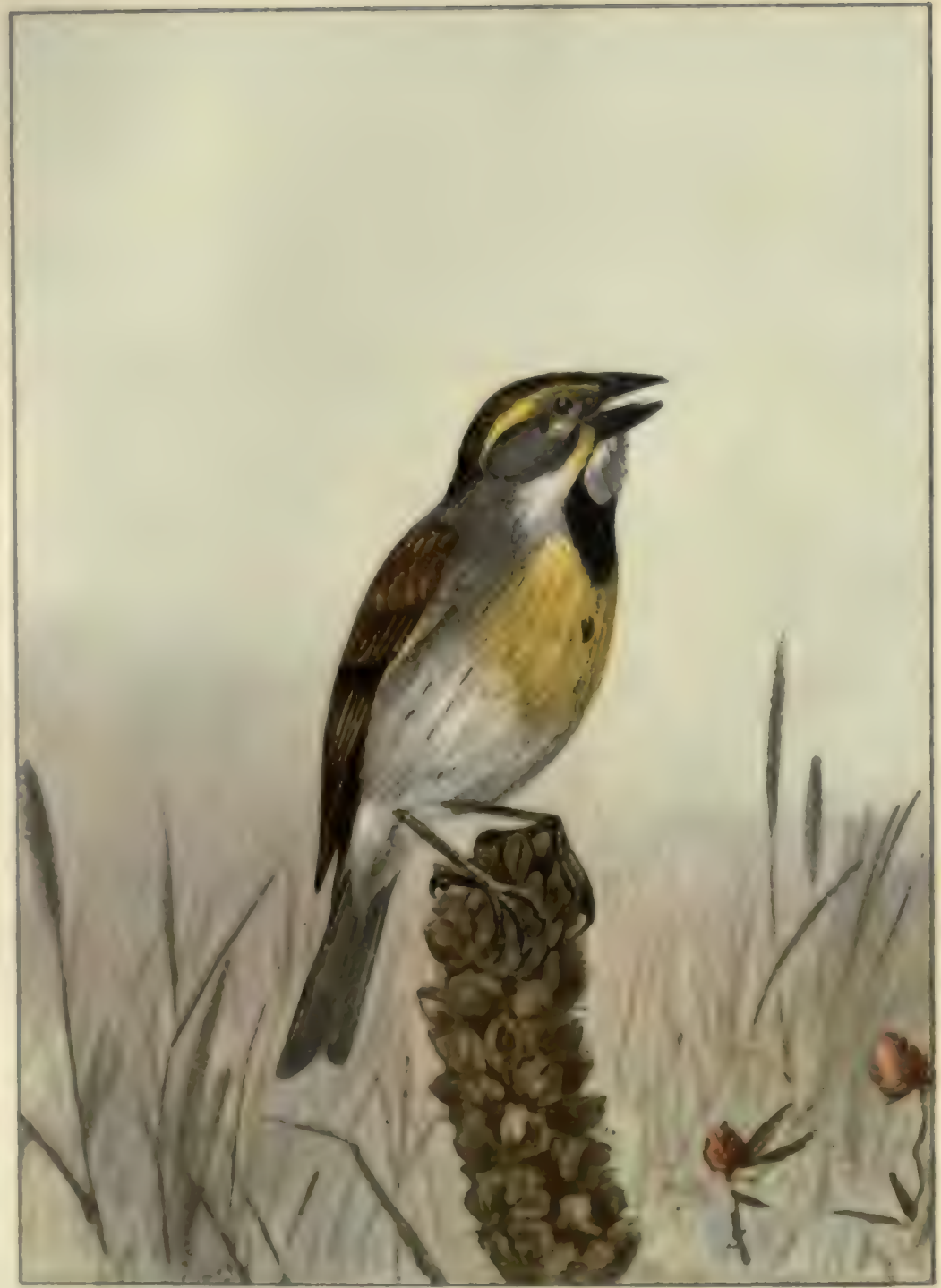

Puate LVI.

Pagi 165.

DICKCIBSEL.

Length, 6-00 Inchea Adwll wale, back black, chestout, and graylsh; leaser wing-coverts bright chestnut ; chin white; throat black ; breast yellow; belly white. Adult female, upper parts stresked black and graylsh; throat white; brenst yellowish, with bleck strenks; belly whito. 

With the Tree Sparrows and Juncos, Redpolls feed on the seeds of plants left uncovered by the snow, and they also incluble hirch buds in their fare.

None of our winter hirds hetter illustrate the flocking habit than the snowflaker, Snow Buntings, or, as they

\section{Bnowflake,} IVabrophiones wiralis. Plute 1.

are also called, White Snowbirds. With a uniformity of movement which would put to shame the evolutions of the best. ilrilled troups, they whirl over the snow-clad fields, wheeling to right or left, as though governed by a single impulse. Suddenly they swing downward into a weedy tield, alighting on the snuw or ground, where they runnot hop about-like little leach birds. Sometimes, it is said, they sing on the wing while with us, but their usual note is a low chirp. They are terrestrial birds, and, although they may often perch on fences or buildings, are rarely seen in trees.

Snowtlakes nest within the Arctic Circle, and, like other of our winter birds that come from the far North, are irregular in their movements. As a rule they do not wander much south of Iong Island and northern Illinois, hut ocensionally they go as far as Virginia and Kansas, and are thus anong the possibilities which add so much to the plessure of winter days in the field.

The Crossbill is a pmssibility at any season. None of our birls is more erratic in its migrations. As a rule, it

American Cromblli. Lewis cerrimueres Plate I.I. is found in the Middle States only between Novemlier and March, but I minor. have seen it in Central Park, New York viry, as late as May. In the higher parts of the Alleghanies and in northern New Enghand it is resilent thronghout the year. Crosshills usually wanler as far south each winter as Connecticut, but lesond this are of irregular occurrence.

They feral slmont entirely upon the seeds of pines, and 
are not often seen far from coniferous trees. Their singular bill might, at first glance, be considered misshapen, but if you will watch a Crossbill push his crossed mandibles beneath the scale of a pine cone, and with a quick twist force it off and secure the seed at its base, you will readily admit that for the bird's purposes his bill could not be easily improved.

In hunting for Crossbills it is a good plan to look through the woods for falling scales of pine cones, and when you see a shower of them whirling softly downward it behooves you to learn the cause of their descent. The birds often follow them to the ground, to secure the seeds which have dropped there.

Crossbills fly in compact flocks, and often utter a sharp, clicking note while on the wing. Their song is sweet and varied but not loud.

Pine Grosbeaks are among our rarer winter visitants. They come as far south as Massachusetts in vary-

Pine Grosbeak, ing numilers, and occasionally reach Pinicola enucleator. Connecticut, but south of this point Plate LI. are of very infrequent occurrence. At irregular intervals Pine Grosbeaks become abundant during the winter in New England, when, because of their size, they attract general attention. They usually resort to coniferous trees, upon the seeds of which they feed, but they also eat berries and buds, and are said to be especially fond of the fruit of the staghorn sumach.

No one seeing the Goldfinch or Yellowbird in his summer costume of gold and black would imagine that 80

Goldfinch, dainty a creature could brave the storms

Spinus tristis. of winter; but late in the season, when

Plate LII. his home life is ended, he changes the gay wedding dress for a plainer suit, and joins the ranks of winter birds.

I wish that every one knew the Goldfinch. His gen- 


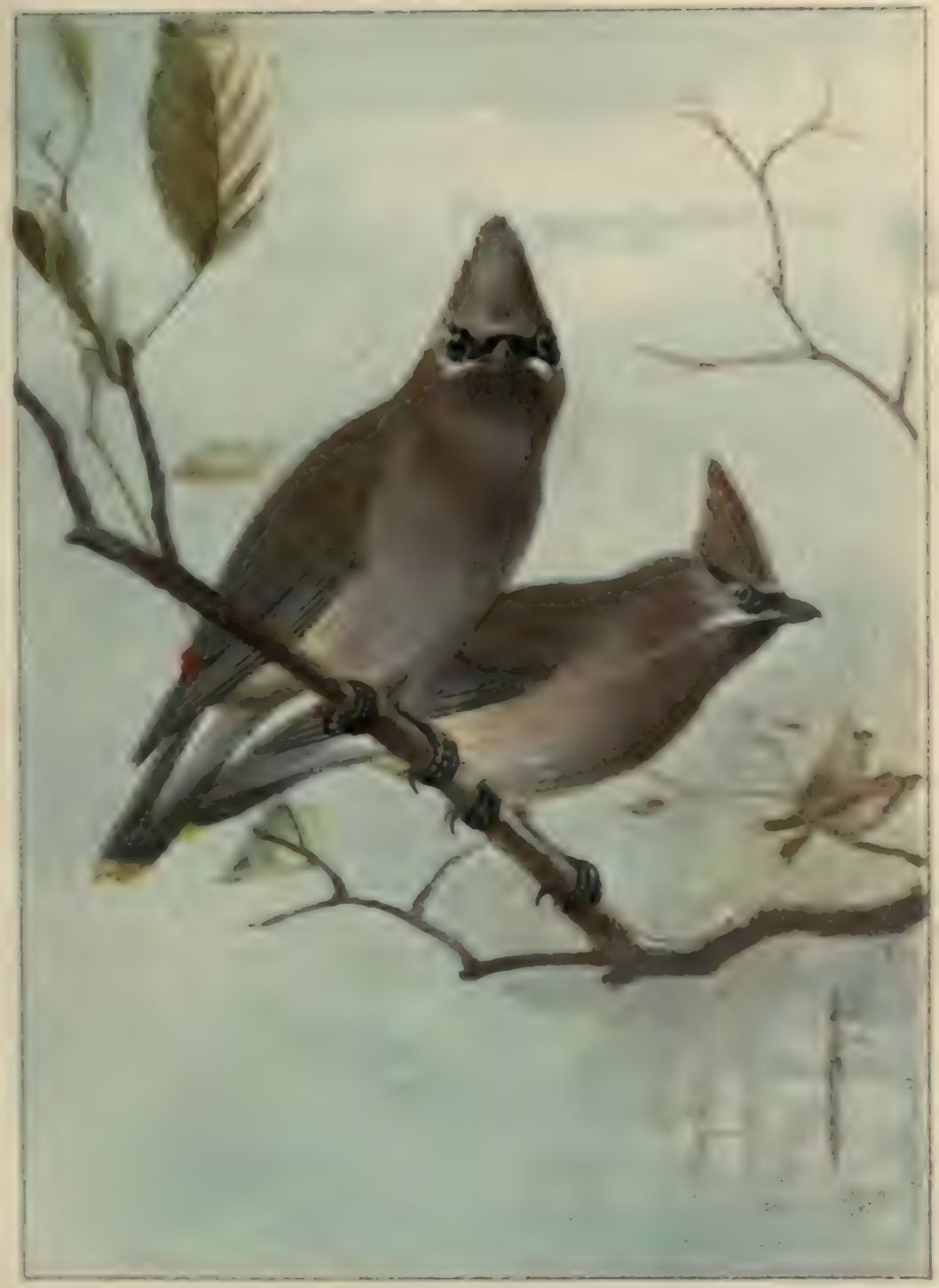

PuATE LVIL.

Plar 161.

CEDAR WAXWING.

Length, 7.20 inobus Grayish brown; upper tall-coverts gray; lower belly yellowtsh; end of ull yellow; secondaries sometimes with rea? ceeling-wax-llke Ups; atripo through taoe black. 

tle ways and sweet disposition are never-failing antidotes for discontent. One can not be long near a flock of these birds without being impressed by the refinement which seems to mark their every note and action. They show, ton, a spirit of contentment from which we may draw more than a passing lossun. Ileur me, heur me, deurie, they call as they feed among the weeds or on the birch buds, and, no matter how poor the fare, they seem thankful for it. The meeds of the dandelion, thistle, and sunflower are among their favorites; and if you would attract Goldtinches as well as some other birds, devote a corner of your garden to suntlowers.

The meal finishel, the birls launch into the air, and to the tume of a cheery per-chic-o-ree, per-chic-o-ree, go swinging through space in long, bounding undulations.

In April the males regain their loright colors, but they are eridently believers in prolonged courtship, and, although the nuptial dress is acquired so early, housekeeping is app urently not thought of until June. Then a neat home of bark and fine grasses, thickly lined with plant down, is placed in a lush or tree, five to thirty feet from the ground, and in it are laid three to six pale, bluish. white egges.

Now the song season has reached its height. Choms singring has been alonulone 1 . Euch hird has become an inspired soloist, who, perchet nesr his home or flying in brond cirrles alwout it, pours forth a flood of melody. It in an ereenlingly attractive song, sweet and varied and suggesting a Cannry's, but still is no more like it than a huthouse is like a tropical forest.

Creuk, crecil, the notes are clear but faint, and may Parplo nach, come from any place beyond arm's reach. canuis. Phery are the Purple Finch's HightFinte L.III. calls; one might think his wing joints neelet oiling. Alighting on the topmost twig of a 
forest tree, he utters a low, wild, questioning whistle. With crown-feathers slightly erect he seems alert and restless, and before we can fairly see him is off again to parts unknown.

Purple Finches, in small companies, may often be seen feeding near the ground with Groldfinches, but if alarmed they soon return to the tree tops. The old males may be known by their pinkish red color, which is brightest on the head and breast, and fades to brownish on the lower back and tail and white on the belly. The young males and females are Sparrowlike in appearance, the upper parts being dark grayish brown, the under parts white, streaked with dusky. A whitish line passing over the eye is a characteristic mark.

During the winter Purple Finches are irregularly distributed throughout most of the Eastern States, but in summer they are not found south of northern New Jersey. They now become more social and may nest in our gardens. Generally a coniferous tree is selected, and the nest of twigs, grasses, and rootlets is placed at a height of about twenty feet. The eggs, four to six in number, are blue, spotted with dusky about the larger end.

Count yourself fortunate if a Purple Finch makes his home near yours. He may appropriate a few buds and blossoms, but he will repay you with music and leave you his debtor. His song is a sweet, flowing warble; music as natural as the rippling of a mountain brook.

Some morning early in May you may meet the Rosebreasted Grosbeak, just returned from a winter's sojourn

Rose-breasted

Zamelodin

Grosbeak,

ludnviciana. Plate LIV. he appeared as a revelation, and after fifteen years I still in South America. Perhaps his fame will have preceded him, when you will in a measure be prepared for his charms of song and plumige, and so miss the keener pleasure of surprise; but to me 


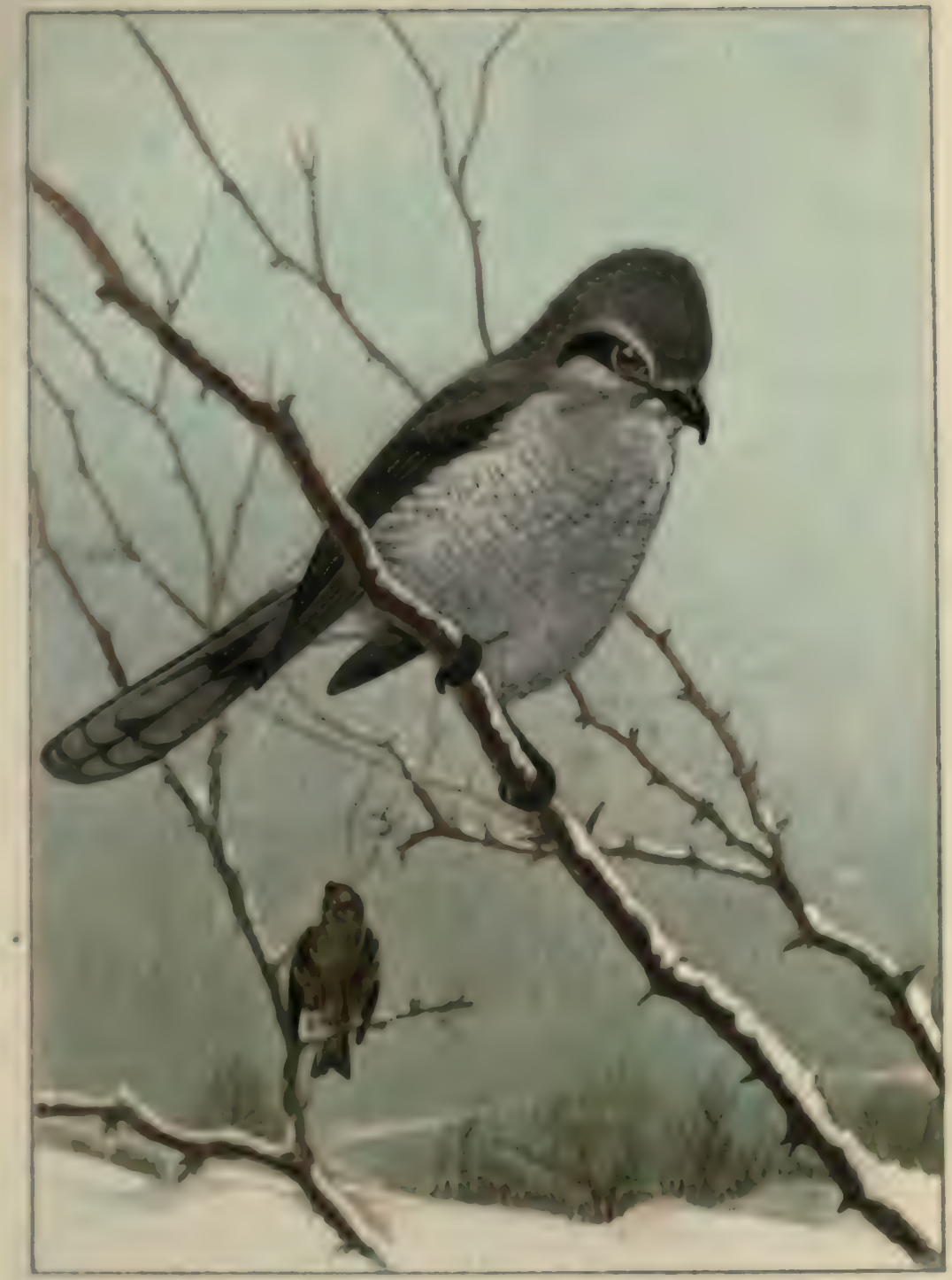

Prate LVII.

Paos 162.

NORTHEBN 8HRIKE.

Lonuth, 10-30 Inches Adalt, upper parts gray; tall black and white; under parta whites. with liackiab bans: Jom graylah; ear-ooverta black. Yowar, sicullar, but plutrage wabher wilch brownish. 

finl it diflicult to believe that, unknown to me, this bean. tiful creature could long have heen an inhabitant of my woods.

The firuslienk prefers young second growtle, with a lilemal proportion of oaks. In one of these trees he will doubless build his nest, a structure so lightly made that one ean almonst soe the blue, spotterl eags from below. The male is not only an ardent lover but an admirable lusband, and, unlike most brightly attired birds, shares with his mate the task of inculntion, and, it is said, sinns while on the nest. Ilis mate is so unlike him in color that fow would suspect their relationship. She silguests an overgrown female Purple Finch, with the eye-stripe especially prominent; but if you should chance to see the under surface of her wings, you would find that they were linel with gold. Ilowever, the call-notes of buth sexes are alike - n sharp, characteristic peek, which you will have no difficulty in recognizing after you have learned it.

The Grosheak's song will remind you of a Rohin's, but it is in truth \& much higher type of bird music. It is a joyous carol, expressive of a happy disposition and a clear conscience.

The Towhee, or Chewink, is an important member of any hiri community. He comes early-A pril 20 may Pipile find him with us-and he stays late, Towheo,

enyesmphethationus. P'Inte I. $\mathrm{V}$. sometimes remaining until November 1. I) uring this period there is not an hour of the day when you can not find a Chewink if you know how to look for him. At milday you will perhaps have to summon him by a whistled to. whice from the depths of his bushy home on the border of a wood or thicket; but he will soon respond, and with a fluff-Alnff of his short, rounded wings, tly jerkily up to inquire what's wanted. 
Some birds, such as the Red-eyed Vireo, can sing just as well while hunting food as at any other time ; in fact, I do not remember ever seeing a Red-eye pause long in its search for insects - song and search go on together. But with the Chewink singing is a serious matter, not to be associated with the material question of food; so, when singing, he abandons the dead leaves he has been tossing about so vigorously, and, mounting a perch, becomes an inspired if not gifted musician. Sweet bird, sing, a friend writes it, the "sing" being higher, sustained, and vibrant. To this there is often a refrain which suggests an answering, tremulous I'll try.

Matins or vespers over, the Chewink returns to the ground and resumes his occupation of scratching among the leaves for breakfast or supper, as the case may be.

The Chewink's nest is placed on the ground, often in dried grass, beneath a tangle of running wild blackberry. The eggs, four or fire in number, are white, finely and evenly speckled with reddish brown.

There are three birds who sing not only through the heat of midsummer but are undaunted by the warmth of

Indigo Bunting,

Passerina cyanea. a midday sun. They are the Wood Pewee, the Red-eyed Vireo, and the Indigo-bird or Bunting. The Pewee and Vireo, singing dreamily from the shady depths of a tree, carry the air to the hummed accompaniment of insects; but the Bunting, mounting to an upper branch, gives voice to a tinkling warble, more in keeping with the freshness of early morning than the languor of noon. July, July, summer-suminer's here; morning, noontide, evening, list to mee, he sings so rapidly that human tongue can scarce enumerate the words fast enough to keep pace with him. The Indigo-hird is in song when he comes to us from the South early in May, but it is not until other 


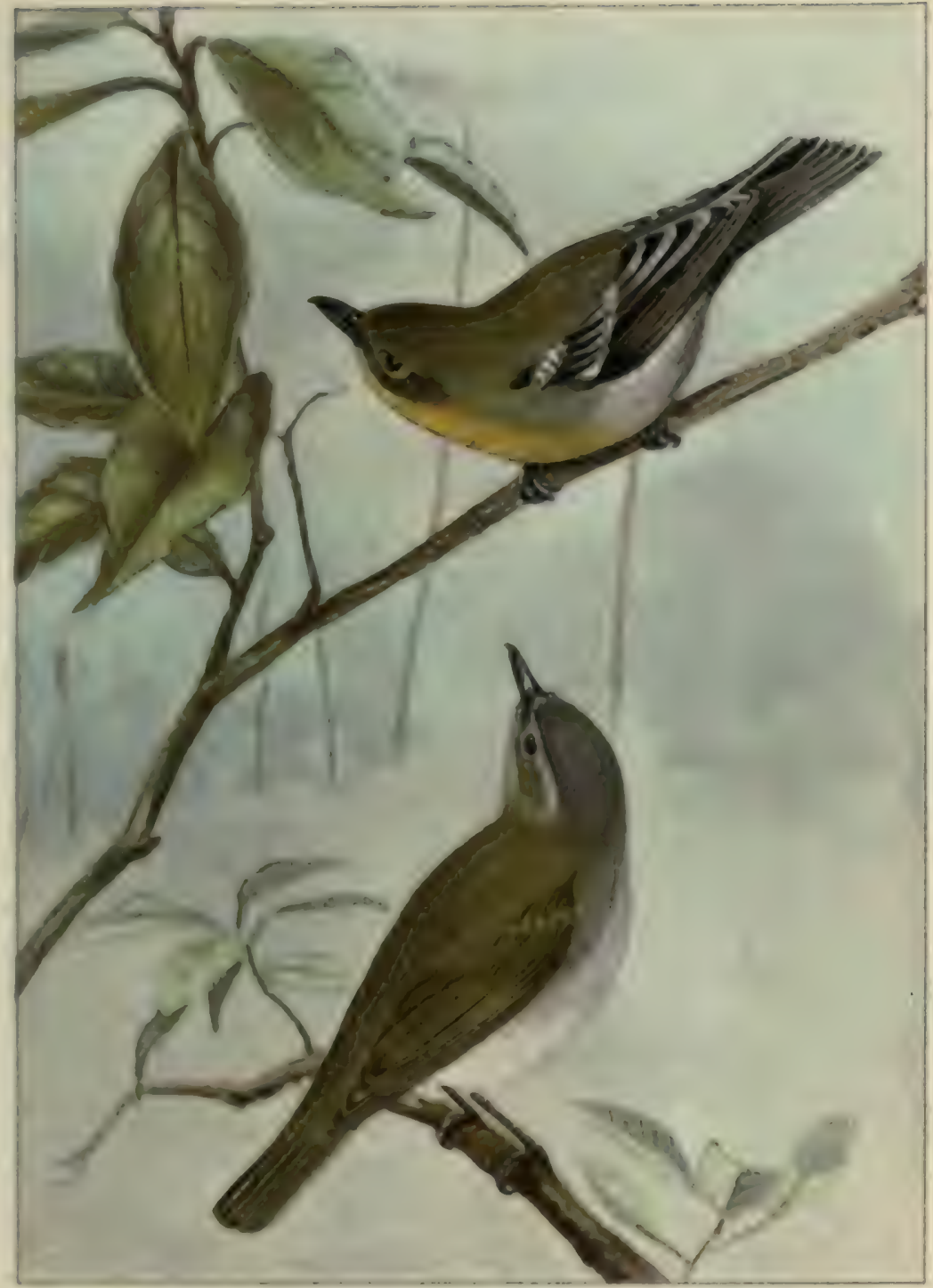

Phave 1.IX.

RED-EYED VIREO.

PAON 164, 165.

Length, 6.25 Inchea. Crown gray, hordered by black and whlte; back, winge, and tall ollvergreen; under parts wulte.

\section{YEI.LOW-THBOATED VIREO.}

Length, 5.85 Inches. Crnwn and back greenish yellow; rump gray; breast bright jollow; bolly whlte; whig-bars whlte. 

singers have dropped from the chorus that his roice becomes conspicuous.

Not far away his mate is doubtless sitting on her blnish white eggs in a nest low down in the crotch of a bush. He in his deep indigo costume may be easily identified, but she is a dull brownish bird, about the size of a Canary, sparrowlike in appearance, though with unstreaked plumage, and a difficult birl to name, even when you have a specimen in your hand, while in the bush, if silent, she is a puzzle. But she is far too good a mother not to protest if you venture too near her home, and her sharp pit or peet usually calls her mate, whom you will recognize at once.

The Cardinal is about the size of a Towhee, with plumago which, except for a black throat, is almost wholly rosy red. Seeing a mounted

Cardinal, Candimales curdinatio. Cardinal, one might imagine that he was a conspicuous bird in life and easy to observe; but the truth is that, in spite of his bright colors, the Cardinal is a surprisingly difficult bird to see. You may often hear his sharp, insignificant tsip without catching a glimpse of the caller, so well can he conceal himself. Ilis olive-brown mate is, of course, even more difficult to find, and when you do see her you wonld hardly suspect the relationship were it not for her actions and the striking crest worn by both sexes.

The Cardinal's song is a rich, sympathetic whistle. His mate also sings at times, and I carry in my memory a musical courting I once observed, in which a pair of these beautiful birds were the actors. The song begins with unhee-yom, whee-ynu, long-drawn notes, which are followed by a more mapid hurry, hurry, hurry; quick, quick, quick, and other notes difficult of description. The Cardinal is a bird of the Southern rather than of the Northern States, and is rarely seen north of New 
York city. It is, however, a permanent resident throughout its range, and to one who associates it with magnolias and yellow jessamine it seems strangely out of place amid snowy surroundings.

The Cardinal builds its nest about four feet from the ground in thickets, laying three or four eggs, which are white or bluish white, speckled and spotted with grayish or reddish brown.

In the Mississippi Valley and westward there are several members of this family who are rarely found east

Lark Finoh, of the Alleghanies. Prominent among Chondestes them is the Lark Finch, a handsome grammacus. bird, about six and a quarter inches long, with ear-coverts and sides of the crown chestnut, the back grayish brown streaked with black, the outer tail-feathers tipped with white, and the under parts white, with a single black spot in the center of the breast.

This is a migratory bird, arriving in southern Illinois about the middle of April and remaining until September or Octoher. Mr. Ridgway, in his Birds of Illinois, says that its favorite resorts are "fertile prairies and meadows adjoining strips or groves of timber. In Illinois it evinces a special fondness for cornfields, in which it builds its nest at the foot of the stalks, while the male sings from the fence or the top of a small tree by the roadside."

Its song, the same writer continues, is "composed of a series of chants, each syllable rich, loud, and clear, interspersed with emotional trills. At the keginning the song reminds one somewhat of that of the Indigo-bird (Passerina cyanea), but the notes are louder and more metallic, and their delivery more vigorous. Though seemingly hurried, it is one continuous gush of sprightly musie; now gay, now melodious, and then tender beyond description-the very expression of emotion." 


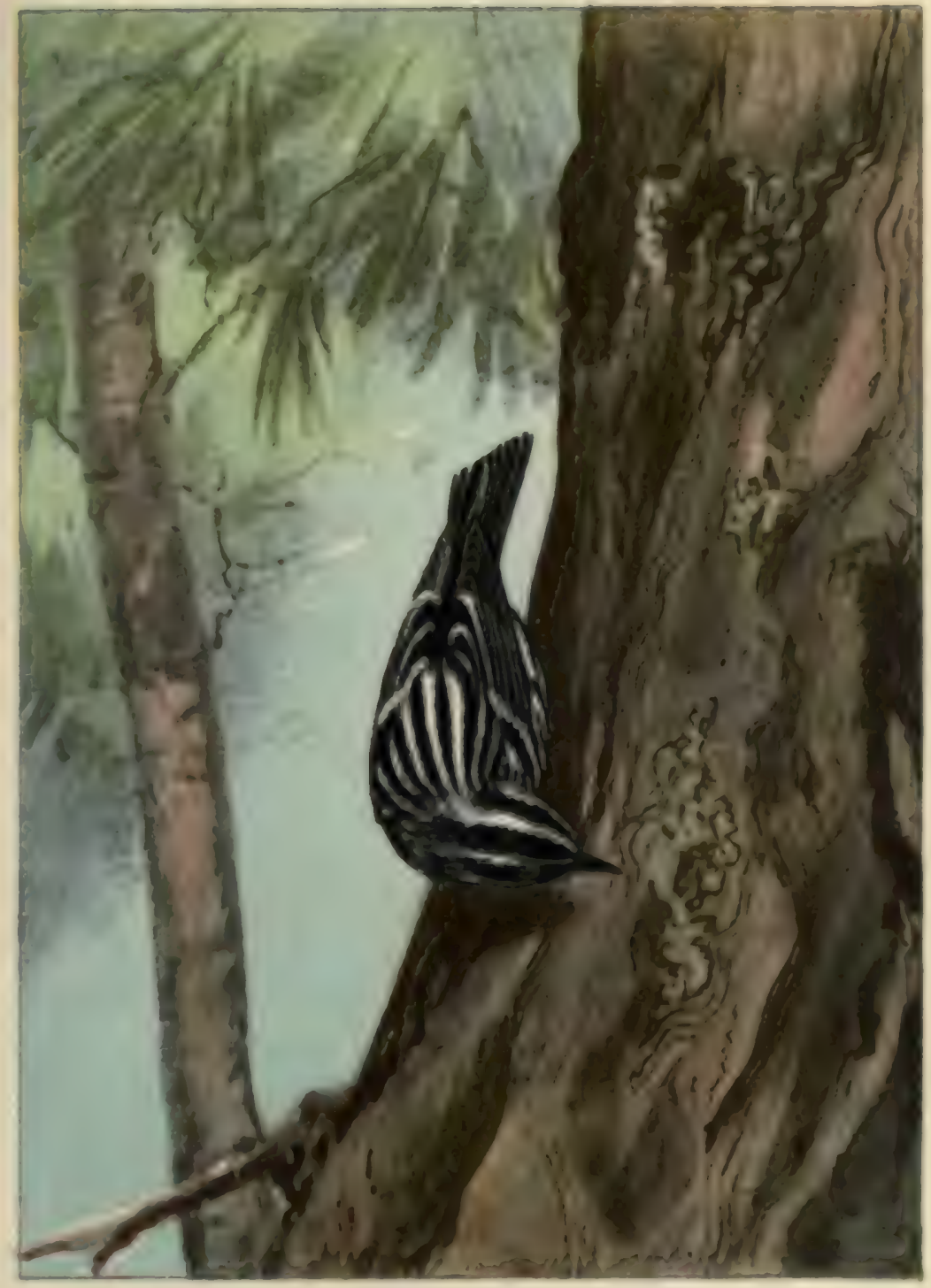

Phate LX.

Page 167.

BLACK AND WHITE WARBLER.

Length, 5.25 Incheas Adwis male, npper parte, breast, and sides black and white: belly whlte. Adull female, similvr, but with leses black on usder parta. 

Some thirty or forty yeans ago the Dickcisisel, or Black-throated Bunting, was a locilly common bird in

Diekoissel,

ipisa amerisesas

I'late L.VI. the Middle Atlantic States. Now it is rarely found east of the Alleghanies, and even in the Mississippi Valley its range is becoming restricted, and it is of irregular distriLution.

It migrates in large flocks, the males in the spring being several days in advance of the females. About May 1 it reaches the latitude of Chiengo, and by the middle of the month is mated. The nest is placed on the ground, or in low trees or bushes; the egrgs, four or five in number, are pale blue.

In the work previously quoted from, Mr. Ridgway writes of this species: "While some other birls are equally numerous, there are few that announce their presence as persistently as this species. All day long, in spring and summer, the moles, sontimes to the numher of a dozen or more for ewh mealow of consiclerable extent, pereh upon the summits of tall weed stalks or fence-stakes, at short intervals, crying out: Ses, seeDirk, Dick Cissel, Ciswel ; therefore 'Dick Cissel' is well known to every farmer's hoy as well as to all who visit the country during the seanon of elover blossoms and wild rumes, when 'Dame Nature' is in her most joyous mool."

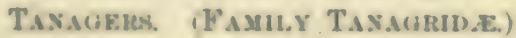

The Tanngen, numbering sume three hundred and fifty species, are found only in Amerien. Their home is in the troppies, where they are among the most abundant of birds. But two species reach the eastern Inited States, the Summer leedbird of the South and our Scar. let Tanager, Inoth worthy representatives of a group of birls which in brillianey of color rival even the IIum. 
mingbirds. The male Scarlet Tanager, with fire-red body and jet-black wings and tail, is the most brightly plumaged of our birds. Seen against a scarlet Tanager, leafy background, light seems to radiPiranga erythromelas. ate from his glowing feathers. But the female, clad in dull olive-green, is so in harmony with the color of her surroundings that she is not easily discovered. The young male at first resembles his mother, but has blackish wings and tail, and does not acquire the full scarlet and black plumage until the following spring. After the nesting season is over the male exchanges the nuptial dress, which has rendered him so conspicuous, for a costume similar to that worn by the young male.

The Scarlet Tanager spends the winter in Central and South Ameriea with his numerous relatives, and in the spring reaches the latitude of New York city about May 5 , remaining until October. It frequents both high and low woods, but prefers rather open growths of white oak. Its nest is usually placed on the horizontal branch of an oak limb. The three or four eggs are pale greenish blue, with numerous reddish brown markings.

The Tanager's call-note is a characteristic chip-churr ; his song is not unlike the Robin's, but is not so free and ringing. Mounting to the topmost branch, often of a dead or partially dead tree, he sings, Look-up, way-up, look-at-me, tree-top, and with frequent pauses repeats the invitation.

\section{Swallows. (FaMily Hirundinid}

Primarily, Swallows are remarkable for their power of flight. Their long, bladelike wings show how well they are fitted for life in the air; their small feet, on the other hand, are of little service except in perching, and give evidence of the effect of disuse (see Fig. 6). 


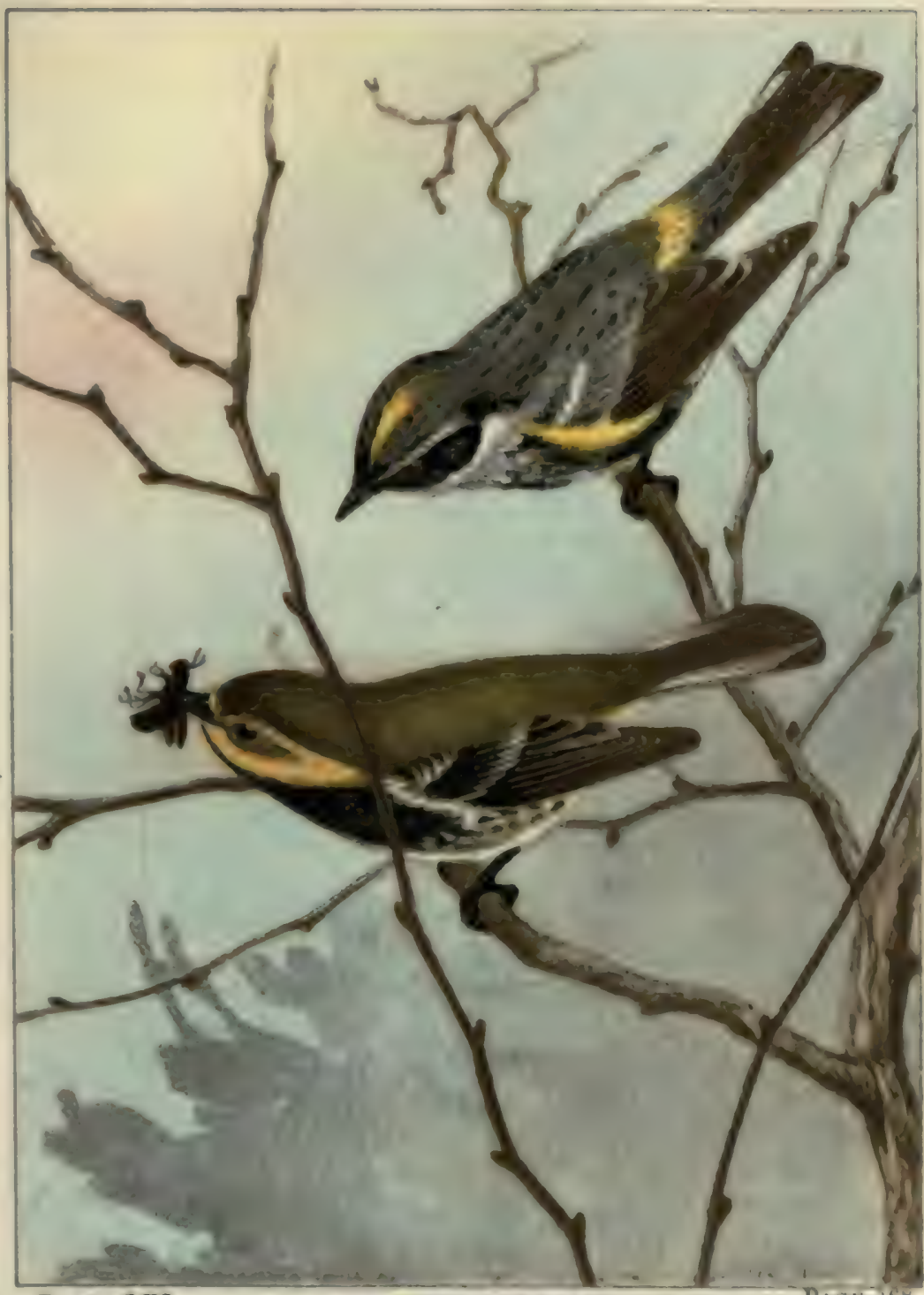

Plate LXI.

MYRTLE WARBLER.

PAGN 168.

Length, 8.65 inchee. Winer plumage, orown-patch, rump, and sliles of bromant yellow; baik brown and black; under parts black and white. Summer plumage, simllar, but upper parts gray and black; more black on under parta.

BLACK-THROATED GREEN WARBLER.

Length, 5.10 Inches. Upper parts yellowleh green; face brighter: breast black; belly white. 

The aerrial aliility of Swallows accounts for their wide distribution, the eighty known spe:ies being represented in all parts of the world. Only six of them inhabit the northeastern States, hut they are so active and so easily observed, that they rank anong our most abundant and hest-known birds.

Swallows are eminently insectirorous. The Tree Swal low is known to feed on baylerries when its usual fare is wanting, lut, with this exception, it is doulttful if any but insect food passes a Swallow's bill from one year's end to another. Recalling now the activity of Swallows, which both necessitates a large supply of food and procures it, and we must realize that these birds are incalculably beneficial.

Both the feeding halits and powers of flight of Swallows are such as their structure would lead us to expect, but when we examine their nests we are amazed at the architectural skill of builders so poorly provided with tools. The large mud pocket of the Barn Swallow, the elay retort of the Cliff Swallow, and the long burrow which the Bank Swallow excarates, are surely not the kind of homes we should expect these small-billed, weak. foote - duinty creatures to construct. We will note, too, that these feathered architects are quick to pereeive and tnke advantage of the new and farorable conditions for nest-huilding found alout the home of man.

The Bank, Rough-winger, and Tree Swallows, and the Purple Martin, lay white eggs; the eggrs of the Barn and Cliff Swallows are speckled with cinnamon, olive, and reddish brown.

It is when nesting that Swallows best show one of their strong characteriatic - their sociability. Many birds live in flocks during part of the year, but separnte in pains when nesting: lut most Swullows live on terms of such intimary that their nests seem to be merely apartments in 
one great dwelling. $\Lambda$ photograph of part of a colony of Cliff Swallows in Montana shows one hundred and forty nests, nearly all of which adjoin one another.

The songs of Swallows are humble efforts, but are so expressive of the happy dispositions of the birds, and so associated with scenes with which they are inseparably connected, that the merry twitterings of these birds are as dear to us as the voices of friends.

The sociability of Swallows does not end with the nesting season, as it does with many birds that are then brought into communities by force of circumstances. When the young take wing, Swallows begin to collect in flocks, which gradually unite, and in August and September form assemblages containing millions of individuals. They generally make their headquarters in some large marsh, where they roost in the reeds and grasses, but they also resort to trees. Early in the morning they scatter over the country in small bands, flying at a considerable height, and during the day we may often see them feeding over fields and ponds or resting on wayside telegraph wires. Late in the afternoon they begin to return to their roosts. At first they fly slowly and circle about to feed, but as the light fails they fly with increasing swiftness, and the last comers shoot through the dusk with incredible rapidity.

These remarks apply with equal truth to all our Swal. lows; it remains now to briefly mention the characters by which they may be distinguished specifically. The four common species are figured in the frontispiece, which clearly shows most of their diagnostic marks, which are: Tail forked, Barn Swallow; forehead whitish, rump rusty, Cliff Swallow ; a band across the breast, plumage without metallic colors, Bank Swallow; breast pure white, Tree Swallow. 


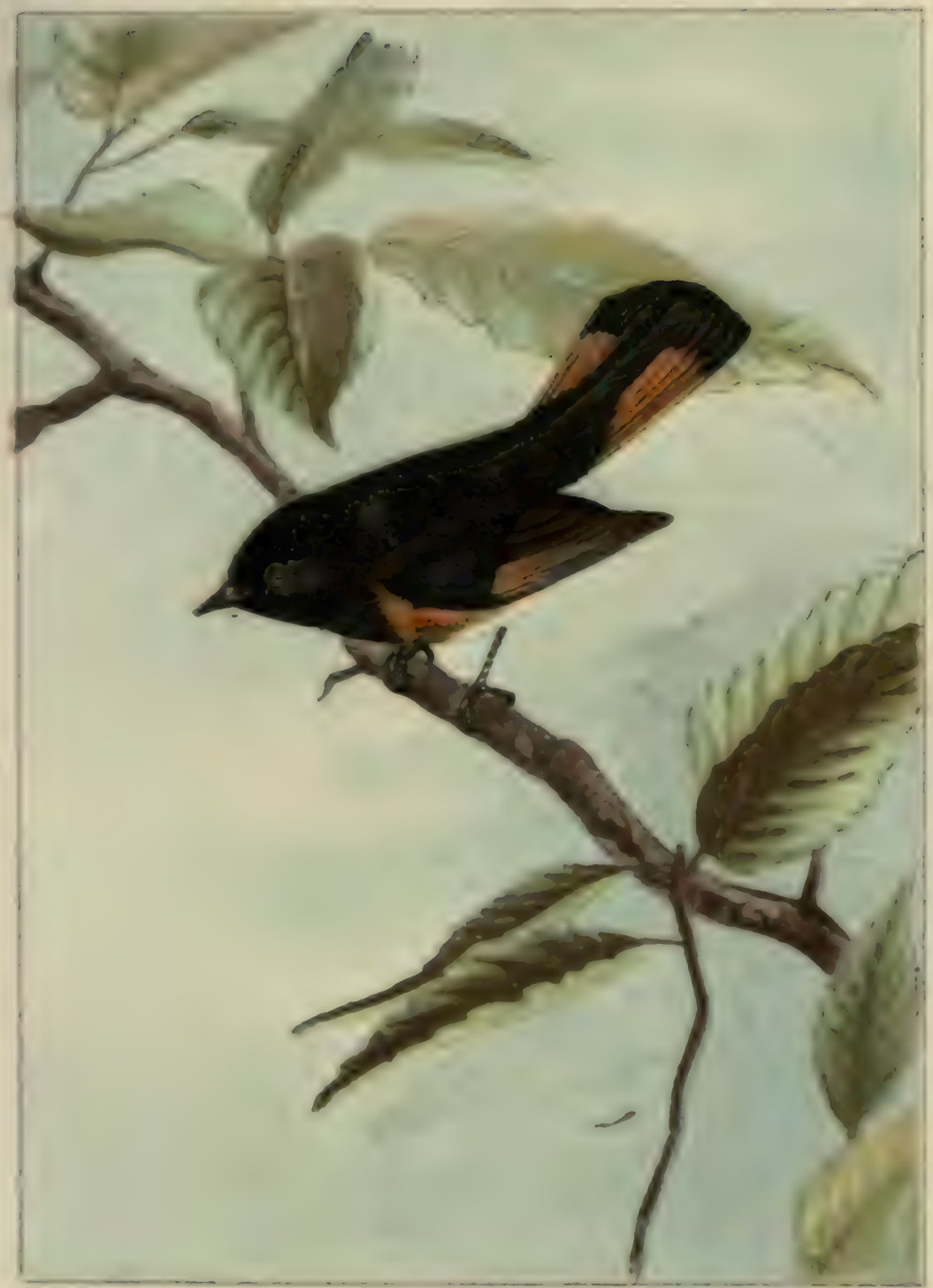

PLate LXII.

KRDSTYRT.

Length, B-40 Inches. Adwht male, band In wings; base of tall and stdes of breast deep malmon; belly whito; rest of plumage hlauk. Adwht female and young, altullar, but ealmon replaced by yellow; upper parts graylah brown; under parts whito; breast yellowish. 

The Bam Swallow is the most generally distributed of our Swallows, its labits of nesting in outluildings Ban swallow, making it at home wherever they offer
it a suitable nesting place. It is about
(Frenti-phowe.) seren inches long; the upper parts and
sides of the breast are stecl-blue, the forehend and throat chestnut, the rest of the under parts puler; the tail deeply forked and marked with white. Its long tail is a most eficient rudler, permitting the alorupt turns which make its flight more erratic than that of any other of our Swallows. It skims low over the fields, or clurts through the village streets with a rapidity and indireetness which I never witness without astonishment.

The Barn Swallow arrives from its winter home in the tropies about $A$ pril 15 and remains until late in September. It nest is generally placed on a beam in a larn or other outbuilding, and is composed of mud and graseses linet with feathers.

The Cliff or Fave Swallow is less generally distributed than the IBarn Swallow. It nests in colonies, placing its

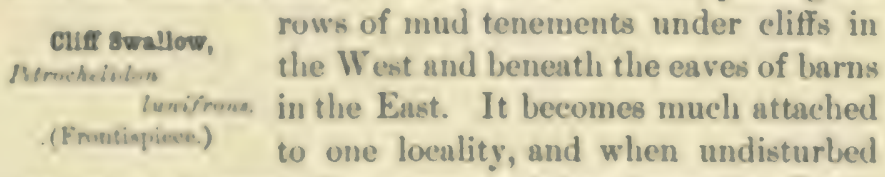
returns to it year after year, arriving from the South utout Masy 1, and remaining until late September. It is six inches long; the forehend is whitish, the crown and hasck steel-bilue, the rump rusty; the throut chestnut with a blackish ares: the belly white.

like the Cliff Swallow, the Bank Swallow nests it. colonies, and is very lesal during the breeding season. A Bank smillow, sandbank facing a stream or pond is

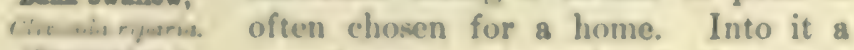
ifrentiones tunnel two or three feet in length is borel, and at its end a nest of grawes and feathers is built. 
The Bank Swallow winters in the tropics and reaches us in the spring about April 20, remaining until late September. It is the smallest of our Swallows, measuring only five inches in length, and is the only one, except the Rough-wingel Swallow, which has no metallic coloring in its plumage, the back being plain brownish gray, the under parts white, with a clearly defined brownish gray band across the breast. The Rough-wing is a more southern bird, being rare north of southern Connecticut. It resembles the Bank Swallow, but differs chiefly in having the whole breast brownish gray. It nests in holes in banks, and also about stone bridges, trestles, and similar structures.

Though very generally distributed, there are large areas within the breeding range of the Tree Swallow

Troe Swallow, where it is known only as a migrant. Tachycinuta bicolor. In the wilder part of its range it nests

(Frontispiece.) in hollow trees; in the more settled portions it uses bird-boxes. During recent years, as $\mathrm{Mr}$. Brewster has remarked, the always-present House Sparrow has pre-empted the former abodes of the Tree Swallow, so that it no longer nests about our homes; but as a migrant its numbers are undiminished, and it is probably our most abundant Swallow.

Being the only Swallow to winter in the eastern United States, the Tree Swallow is the first to arrive in the spring, coming to us from Florida early in April. It is also the last of its family to leave us in the fall, often remaining near New York city until October 20.

Immature birds have the upper parts brownish gray instead of shining steel-blue, as in the adult, but in either plumage the bird may be known by its pure white under parts, which have given to it the name of White-bellied Swallow.

In the northern United States Martins are very local. 


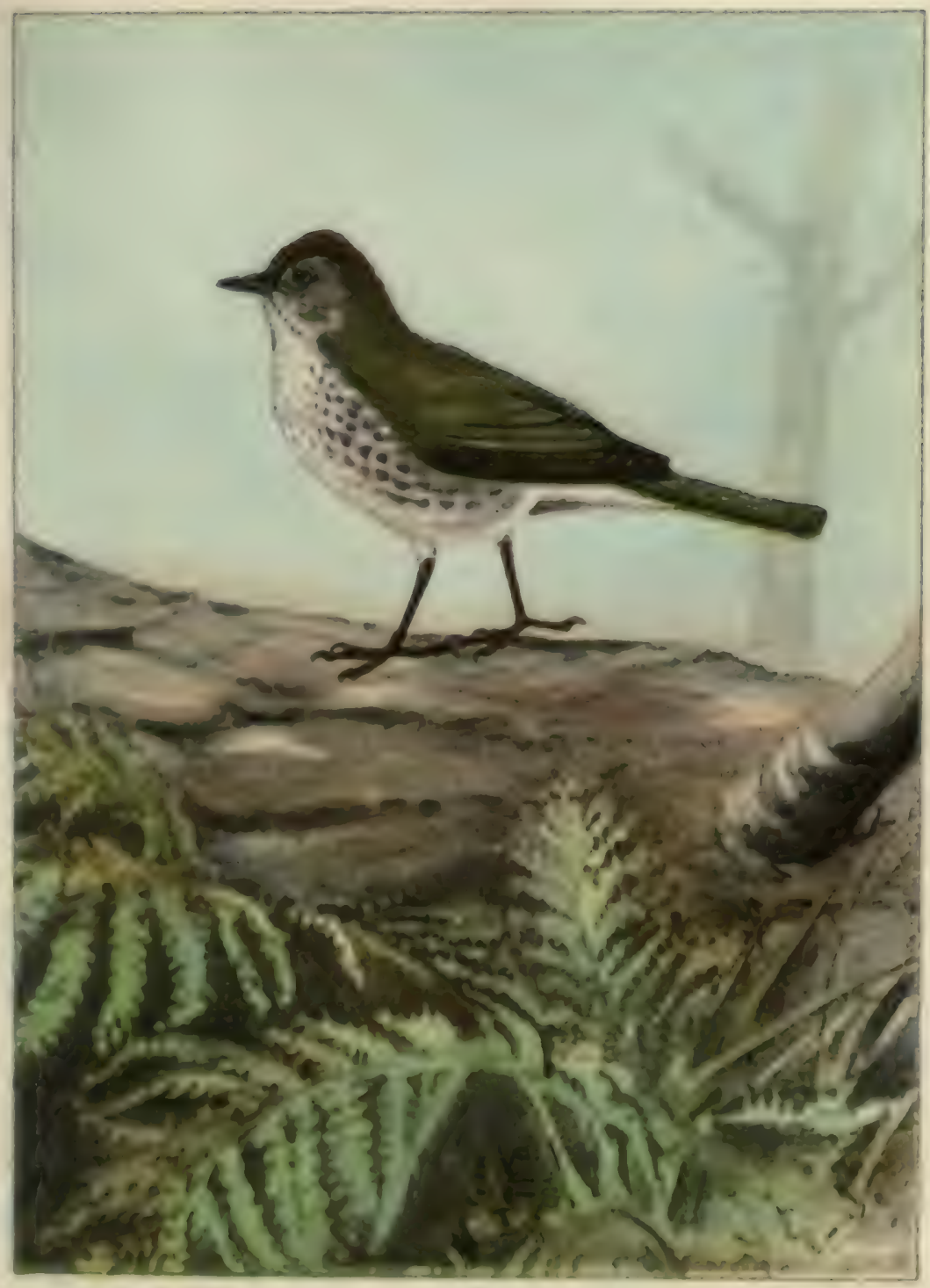

Puate IXIIL.

PAOX 170.

\section{OVEN-BIRD.}

Leagth, 6.16 Inehee. Orown resdlsh brown, bordered by blaok; back, whogen and tall ollve-green; undes parts black and white 

They have long since abandoned their habit of building in hollow trees, and now nest only about houses or in lawns where gourds or boxes are erected for Puple Martin, Phoyno oubie. their occupation. To these they return year after year, corriving in the spring about A pril 25 and remaining until September. The male is uniform steel-blue, and appears black in the air; the female is grayish, tinged with steel-blue alove; the breast is gray, the belly white. This is the largest of our Swallows, measuring eight inchos in length.

\section{Waxwivas. (FAMLY AMPElide.)}

One of the two species of Waxwing is a bird of the far North; the other, our Cedar Waxwing, is found throughcodar Warwing, out North America. Waxwings posAmpeche edrurum. sess in an unusual degree two charac-

Plate LVII. teristics which are not supposed to he sociated-ociability and silence. None of our birds is more companional,le, none more quiet. In their fondness for one another's society they seem to delay the pairing senson, and long after other birds have gone to housekeoping they are still roving about in flocks. Finally, late in June, they settle down and build a nest of generous proportions, often in some fruit tree, about ten feet from the ground. The three to five eygs are pale bluish gray or putty-color, apotted with black or brownish black.

Waxwings fly in close rank and alight as near each other as the nature of their perch will ailow. They sit very atill, like little Parrots or Doves, but often mise and lower their crests, and perhaps whisper a fine lisping note, which is prolongerl into a louder call $\longrightarrow$ a string of beady notes - as they take wing.

Their fare varies with the season - cedar berrien, strawberries, cherries, both cultivated and wild, the berries 
of the woodbine, sour gum, and others being taken in turn.

In August the Waxwing shows no mean gifts as a flycatcher, while as a destroyer of the cankerworm he is especially beneficial, repaying us with interest for the fruit he may have appropriated earlier in the season.

The Waxwing's wide range and ability to withstand great extremes in temperature are doubtless due to the ease with which it adapts itself to a change in fare. It nests from Virginia to Labrador, and winters from Massachusetts to Costa Rica.

\section{Shrikes. (FAMILY LaNidD正)}

The marked difference in the temperament of birds is emphasized by finding among the song birds, who feed

Northern Shrike,

Lanius borealis.

Plate LVIII. on fruit, seeds, and insects, a bird who in his position and choice of food is truly hawklike. Shrikes are solitary, never assembling in flocks or associating with other birds. Their days are days of waiting, varied by a pounce upon some unfortunate field mouse or dash into a flock of unsuspecting Sparrows. But, while they resemble the Hawks in these respects, their manner of eapturing their prey differs from that of their larger prototypes. The Shrike has a Hawk's bill but a Sparrow's foot, and, lacking the powerful talons which make so deadly a weapon, he captures his prey with his strong mandibles. Possibly it may be due to his comparatively weak feet that he pursues the singular custom of impaling his prey on some thorn or hanging it from a crotch where he can better dissect it.

The Shrike, or Butcher-bird, as he is also called, belongs to a large family, but, with the exception of his smaller cousin the Loggerhead, he is the only one of the two hundred known species found in America. He nest? 


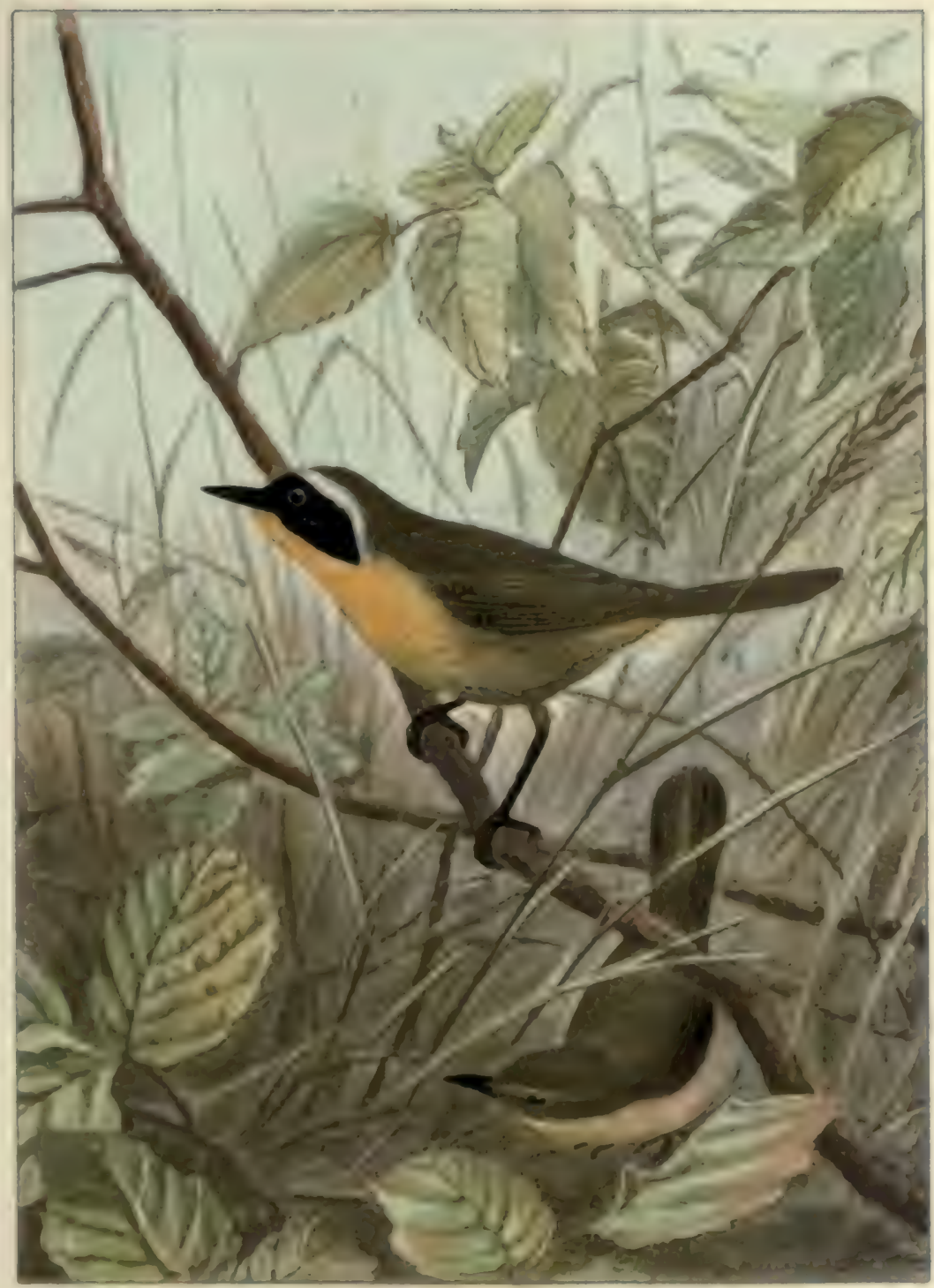

Phats LXIV.

MARYLAND YRLLOW-THROAT.

Paen 171.

Length, 5.80 Inches. Adwlt mak, thoe black, bordered by ahy; back olive-green; breat yellow; belly paler. Adult female, simllar, but no black on twoe; under parto paler. 

within the Aretic Circle, and in Oetoler journeys south. ward, rurely as far a Virginia, and remains in the United States until April or May.

The Loggerliead Slurike is common in the Southem States and Mississippi Valley, whence it has apparently extended eastward through central New York to Ver. mont and Maine. It nests in these States, but sonthward to Maryland is known only as a rare migrant-a unique: ease in distrilution. It differs from the Northern Shrike in being an inch and a quarter smaller, in the alssence of the wavy bans on the breast, which is pure white, and in hav. ing jet-black lores and a narrow black line across the foreheal at the base of the bill. Its song is creuky and anmusical, but the song of the Northern Shrike, as de. scribed by Mr. Brewster, is "really pleasing," and "not. unlike that of the Thrusher, but more disconnected and less lond and varied."

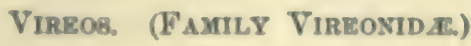

Vireos are gleaners, and are to be distinguished from other troe-inhaliting, greenish hirds of the same size by their habit of carefully exploring the under surface of leares and various nooks and corners in the lark and foliage, while the more sctive Warblers are flitting about the terminal twigs and the Flyentchers are swinging out in aürial loops at passing insects.

They are highly musical little birds, haring songs and call-notes which may he quiekly recognized once they are known. The nests and eggn of our four sunumerresiclent species are so much alike that they are to he known only when accompanie. l by their owners. The White.eyed Vireo inhahits thickets and, as a rule, builds nearer the ground than the arboreal Red-eyed, Yellow. throaterl, and $\mathrm{W}$ arbling Vireos. The nesta are small, 
pouchlike affairs of strips of pliable bark, bits of dead wood, plant-fibers, tendrils, fine grasses, etc., firmly interwoven and suspended from the arms of a forked twig. The eggs are white, with a few black or brownish black spots, chiefly about the larger end.

The Vireos are an exclusively American family, and number some fifty species, of which seven reach the

Red-eyed Vireo, Vireo olivaceus.

Plate LIX. northeastern States. Of these, by far the most common is the Red-eyed Vireo. There are few favorable localities in eastern North America where, in the summer, one may not hear the cheerful sung of this bird. Still, it is so well protected by the foliage, with which its plumage agrees in color, that to those whose ear is not attuned to the music of birds it is unknown. But listen near some grove of elms or maples, and you will not fail to hear its song - a somewhat broken, rambling recitative, which no one has described so well as Wilson Flagg, who calls this bird the Preacher, and interprets its notes as "You see it-you know it-do you hear me?-do you believe it ?" The Red-eye evidently has an inquiring mind, for he never tires of asking these questions. He not only sings all day, but seems unaffected by the heat of summer, and at midday is often the only bird to be heard. One would imagine that few birds had a more even temperament than this calm-voiced singer, but when annoyed he utters a complaining whang-a sound which is a good indication that sumething is wrong in the bird world.

The Red-eye winters in the tropies, and reaches us in the spring about May 1, remaining until October 15 .

A near relative of the Red-eye's is the Warbling Vireo- $\mathrm{a}$ somewhat smaller bird, with a brown, in place of red eye, and without the black margin ahove the white eye-line which can be so easily seen in the Red-eye. The Warbling Vireo is the less common of the two, and is 


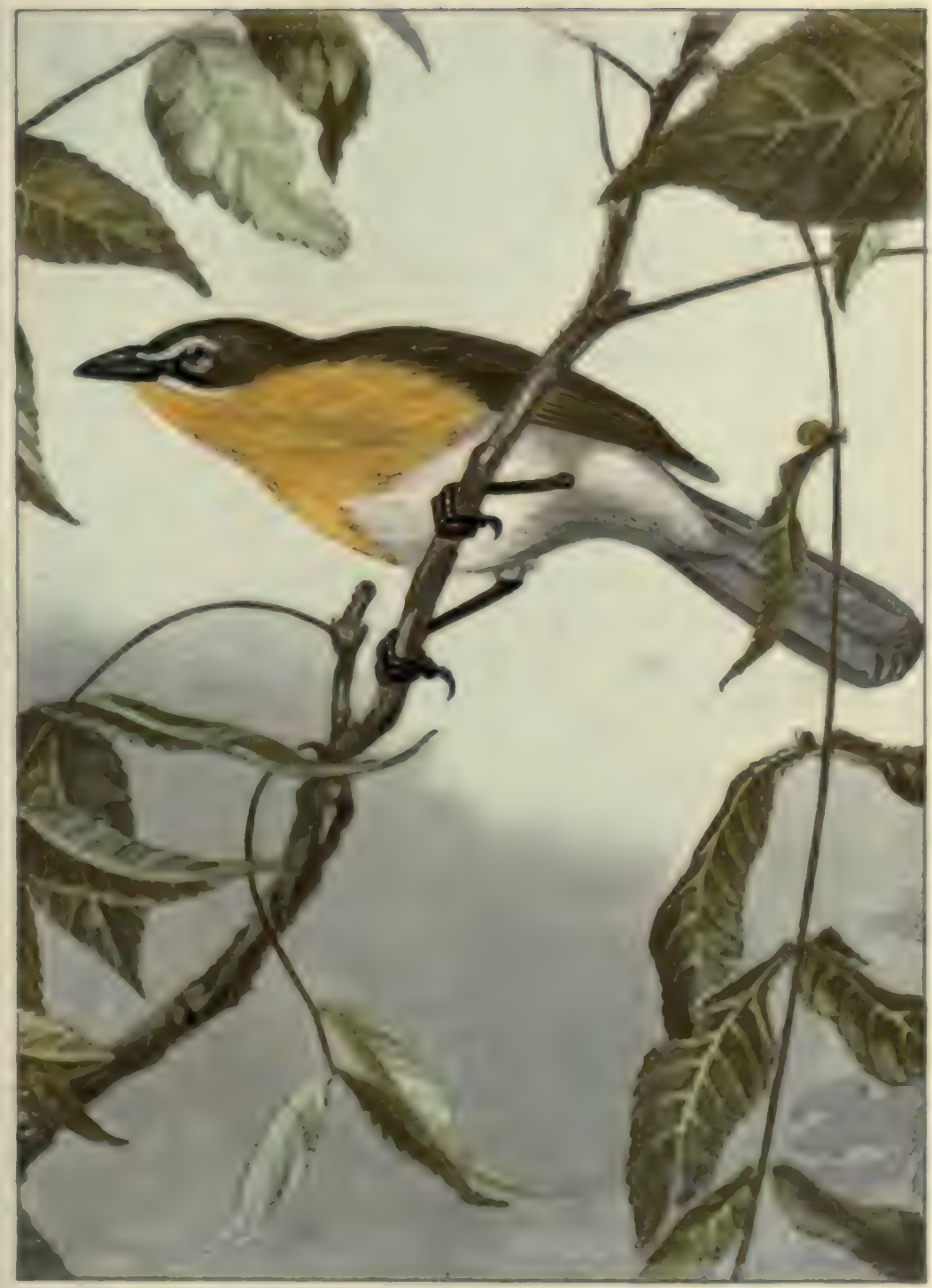

PuAte LXV.

PAan 172.

YELLOW-BREABTED CHAT.

Length, $7 \cdot 45$ Inches. Upper parts ollve-green; breast yollow; belly white; lores black, bordered by white. 

more locul, showing a murked fondness for rows of elms -a taste which makes it a dweller in towns and villages.

Its so $\mathrm{g}$ bears no resemblance to that Warbling Vireo, of the lied-eye, being a continuous, rifoo gileme flowing warble, with an alto undertone, suggestive of the song of the Purple Finch.

The $W$ arbling Vireo arrives from its winter home in the tropics about May 5, and remains until late in September.

Although the Yellow-throated Vireo is least like the Red-eye in color, it resembles it the most closely in choice Yollow-throated of haunts and in song. Still, the YellowVireo, throat's song is sung more deliberately rimo darifrems. and with longer pauses between the Ilute LIX. parts, while in tone it is deeper and richer. To my mind lue says: "See me; I'm here; where are you?" repeating the question in varying forms. Rarely he utters a Leautiful, mellow trill which suggests the song of the Rulyy-crowned Kinglet, and he has also a cacking, scolding note like that of the White-eye. The Yellow-throat's nest is often a more elaborate structure than those of our other Vireos, heing thickly covere.l with lichens, which add greatly to its beauty.

Like the two preceding species, the Yellow-throat winters in the tropics, and reaches the latitude of New York city about May 1. It iloes not, however, remain as long as its relatires, leaving us about September 15 .

The White-eyed Vireo is the genius of his family. What the Chat is among Warblers the White-eye is among Vireos-a peculiar, eccentric Whito-oyed Vireo, bireo nosceburescesnais. bird of strong character, who regards mankind with disapproval, and will hare none of us. Excellent reasons these why we should court his acyuaintance.

Unlike our other Vireos, the White-eye lives in the 
lower growth; thicliets of cat-brier are his favorite haunts. He is therefore nearer our level, and seems to address us more directly than do the birds that call from the tree tops. If you linger near his home he will inquire your business with a vigorous "I say, who are you, eh?" and if you do not take this hint to move on he will doubtless follow it with a scolding whose intent is unmistakable. He has a variety of exclamatory calls, and sometimes may be heard softly singing a song composed largely of imitations of the notes of other birds.

The White-eye can easily be known from the Red-eye and Warbling Vireos by the narrow white bands across the tips of its wing-coverts. In this respect it resembles the Yellow-throat, from which it is to be distinguished by its smaller size (length $5 \cdot 25$ inches), white iris, and white breast, only the sides of the breast being tinged with yellow. It winters from Florida southward, and reaches us in the spring about May 1, to remain until October.

\section{WARBLERS. (FAmily MNIOTILTID An.)}

Warblers may be described as among our most abundant, most beautiful, and least-known birds. Of the thirty-five species regularly found in the northeastern States, only three or four are familiar to the casual observer. The presence of the others is unsuspected, and when some chance brings one of these exquisite little creatures into our lives, the event is attended by all the excitement of an actual discovery. We never forget our first Warbler.

It is because we do not see Warblers unless we look for them that they are strangers to so many persons who go to the woods. They are, with some exceptions, small birds of limited vocal powers. They live in the tree tops, 


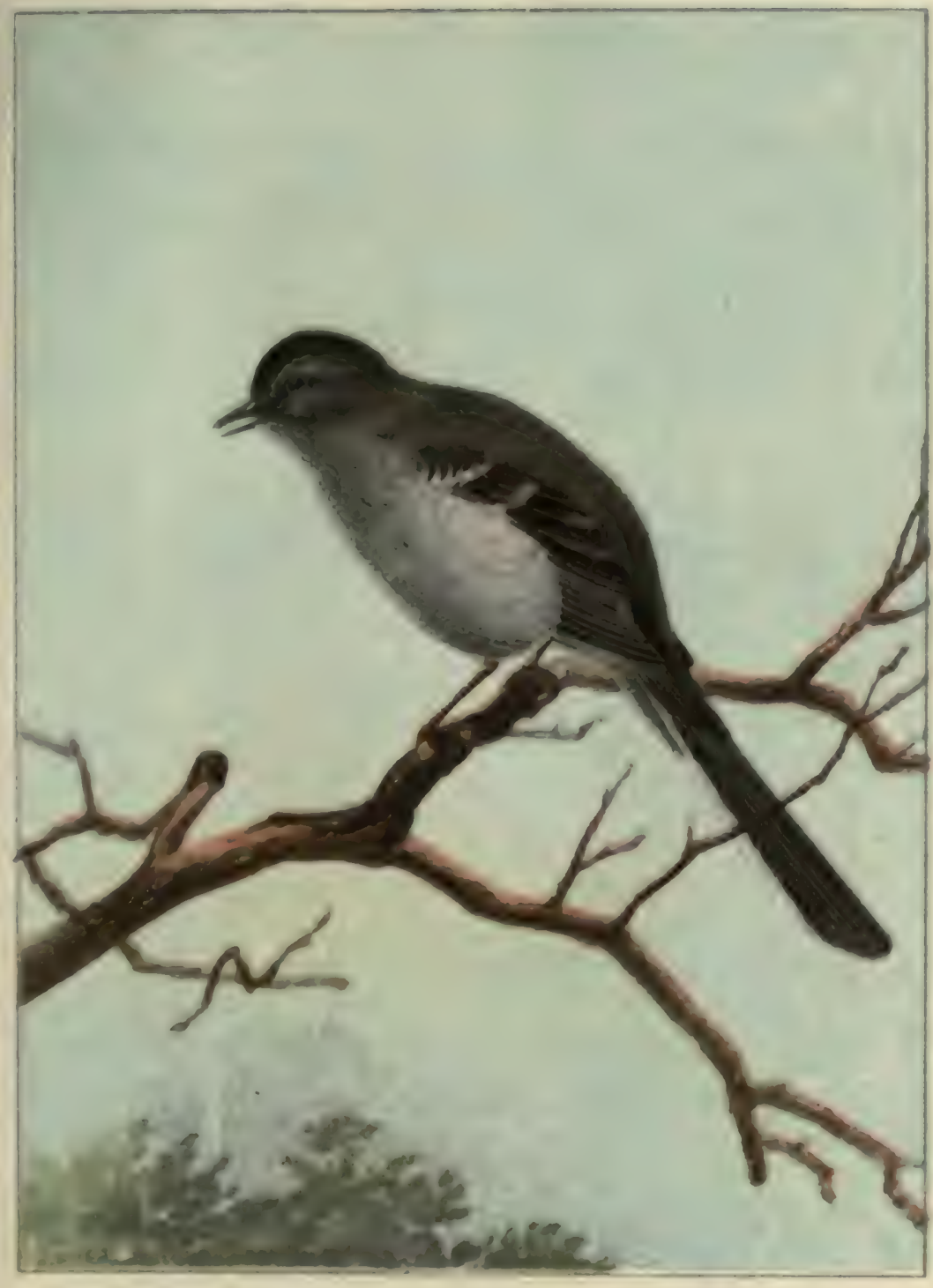

Puate LXVI.

PAa: 17 t.

IOCKING BIRD.

Length, 10-50 Inelime. Uipur parts ashy gray ; wings and tall brownish black and white; under parts white. 

and therr lisping notes blend with other woodland voices without attr: ting our attention.

May and September are the months for Warblers. Some species arrive in April, but they are most numerons between May 5 and 15 , when the woods are thronged with their flitting forms. Less than half of our thirty-five species remain to breed; the others go to their summer homes in the coniferous forests of the North. These northern birds return in the latter part of August and abound in September. Many of the Warblers seen at this season are immature birds wearing plumages so different from those of the adult birds scen in the spring, that their identity is not suspected, and, in effect, they are new birds to us.

To the field ornithologist Warblers are therefore the most difficult as well as the most faseinating birds to study. Long after the Sparrows, Flyeatchers, and Vireos have been mastered, there will be unsolved problems among the Warblers. Some rare species will be left to look for-it may be a memher of the band flitting alout actively in the branches ahove us-and in the hope of finding it we eagerly examine hird after bird until our enthusiasm yields to an aching neck.

Acquaintance with more familiar birds will d/ubtiess arouse the enthusiasm necessary to a successful pursuit of

\section{Dlack and Whito}

Warblers, hut in the meanwhile I will Warbler, mention only those species that can be Snimailtra caria. most easily olserved. Among them is Plate I.X.

the Black and White Warbler, whose habit of creeping or climbing over trunk and limb aids in his illentifiention. He is a summer resident, and about A pril 20 we may expect to hear the thin, wiry see-seesee-see notes which form his song. A month later we may find his nest, placel on the ground at the base of a stump or stone and containing four or tive white 
eggs speckled with reddish brown, chiefly at the larger end.

The Yellow Warbler is also a summer resident, arriving in the spring about April 30 and remaining, with the Black-and-white Warbler, until late Yellow Warbler, in September. It has the general apDendroica astiva. pearance of being an entirely yellow bird, and is sometimes called "Wild Canary," but it has a much more slender bill than the Canary, and its breast is spotted with reddish brown. Most Warblers are woodinhabiting birds, but the Yellow Warbler, unlike its relatives, prefers lawns, parks, and orchards to woodlands. Its nest, of fine grasses, fibers, and a large amount of cottony plant-down, is placed in shrubbery or shade trees. Its eggs are bluish white, thickly marked with cinnamon and olive-brown.

The Black-throated Green Warbler nests in pine forests from southern New England northward, arriving Black-throated from the South about May 1 and reGreon Warbler, maining until October. Its nest is Dendroica virens. usually placed in pine trees; its eggs Plate LXI. are white, spotted and speckled with dark brown.

The songs of many Warblers are possessed of so little character that the best description conveys no idea of them, but the quaint zee-zee, zee-ce, zee of the Blackthroated Green, which Mr. Burroughs writes - - v will be readily recognized.

The Myrtle or Yellow-rumped Warbler nests from northern New England northward, and in winter is the Myrtle Warbler, only Warbler to remain in the NorthDendroica cornata. ern States, being often found as far Plate LXI. north as New York city, when its favorite food of bayberries can be procured. At this season there is little or no black on the breast and the 


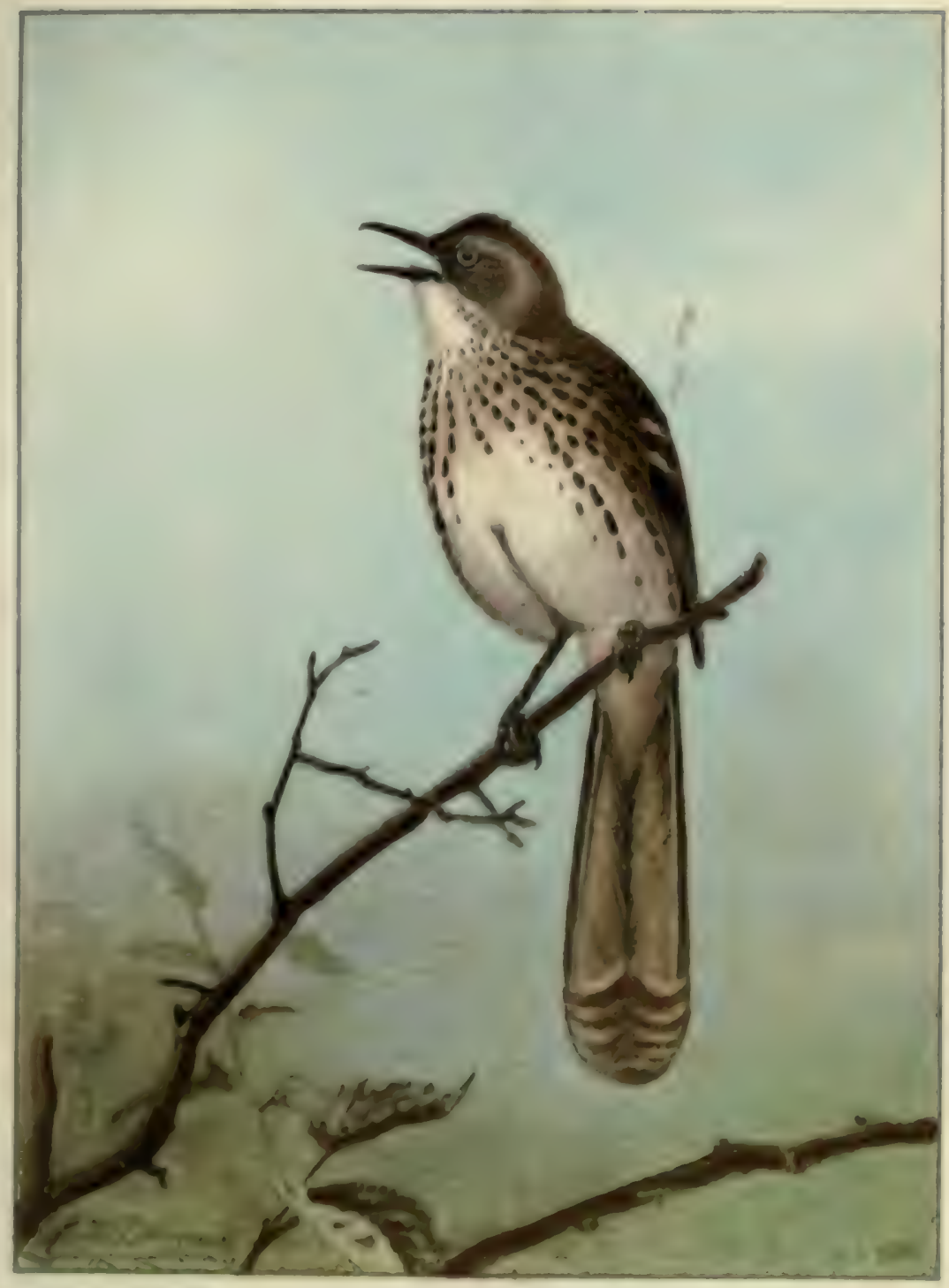

Puars LXVI.

Page 178.

BROWN THRABHER.

Leagth, 11 t0 Inchea Upper parts bright reddlah brown; under parts whlte and blaok; eges yellow. 

back is grayish brown, but this Warbler may always be known by its four patches of yellow and its characteristic call-note of tchip.

The Redstart belongs to the group of fly-catching Warblers, and, as an indication of its manner of feeding,

Rodotart, his bill is much broader and flatter than Setophergys ruticilla. is usual in this family. The Redstart is Plute LXII. not so patient and methodie a flycatcher as the hirds to whom this name rightly belongs. They sit quietly until some insect comes within reach, and then with unerring aim launch out at it, returning to their perch to devour it at leisure. But the Redstart darts here and there, falls and rises and spins about, catching an insect at every turn and at the same time displaying his bright colors to such advantage that he seems the most beautiful as he is the most animated bird of the woods. As he pironettes from lim's to limb, with drooped wings and spre.td tail, he sings ser-wee swee, swee-ee, a simple but merry little jingle.

The Redstart's bright colors, like some mark of special distinction, are not acquire. $\mathrm{l}$ at once. The young male must pass through a periol of probation before he is worthy to wear the orange-red and black. In the meantime he appe.rs first in the costume of the female, and by successive chinges reaches the full dignity of Redstart estate at the nge of three vears. He nest, however, the first year, when his plumage closely resembles that of his mate. The nest, of fine strips of hark, plant-down, and other materials, is built in the crotch of a sapling ten to twenty feet from the ground. The eggrs are grayish white or bluish white, spotted and blotchel, chiefly at the larger end, with cinnamon and olive-brown. They are laid about May 28-four weeks after the birl's arrival from the South.

All the Warblers thus far mentioned are tree-inhabit- 
ing birds, but the species now to be spoken of pass most of their time in the undergrowth or on the ground. The

Oven-bird, Seiurus aurocapillus.

Plate LXIII.

Oven-bird chooses the latter locality. He has been well compared by Mr. Burroughs to a little Partridge, and if you have enough perseverance to find the author of the sharp cheep with which this somewhat suspicious bird will greet you, you will see a modestly attired little walker daintily picking his way over the leaves and fallen branches, with crest slightly erect, and head nodding at each step.

Probably, however, your first acquaintance with the Oven-bird will be made through the medium of his song. There are few bits of woodland where in May and June you can not hear numbers of these birds singing. It is a loud, ringing, crescendo chant, to which Mr. Burroughs's description of "teacher, teacher, TEACHER, TEACHER, TEACHER" is so applicable that no one would think of describing it in any other way. The bird seems to exert himself to the utmost, and no one hearing this far from musical performance would imagine that he could improve upon it. But if some evening during the height of the mating season you will visit the Oven-bird's haunts, you may hear a song whose wildness is startling. It is the flight-song of the Oven-bird, transforming the humble chanter into an inspired musician. Soaring ligh ahove the trees, he gives utterance to a rapid, ecstatic warbling so unlike his ordinary song that it is difficult to believe one bird is the author of them both.

As an architect the Oven-bird is also distinguished. His unique nest is built on the ground of coarse grasses, weed stalks, leaves, and rootlets, and is roofed over, the entrance being at one side. It thus resembles an oldfashioned Dutch oven, and its shape is the origin of its builder's name. The Oven-bird arrives from the South 


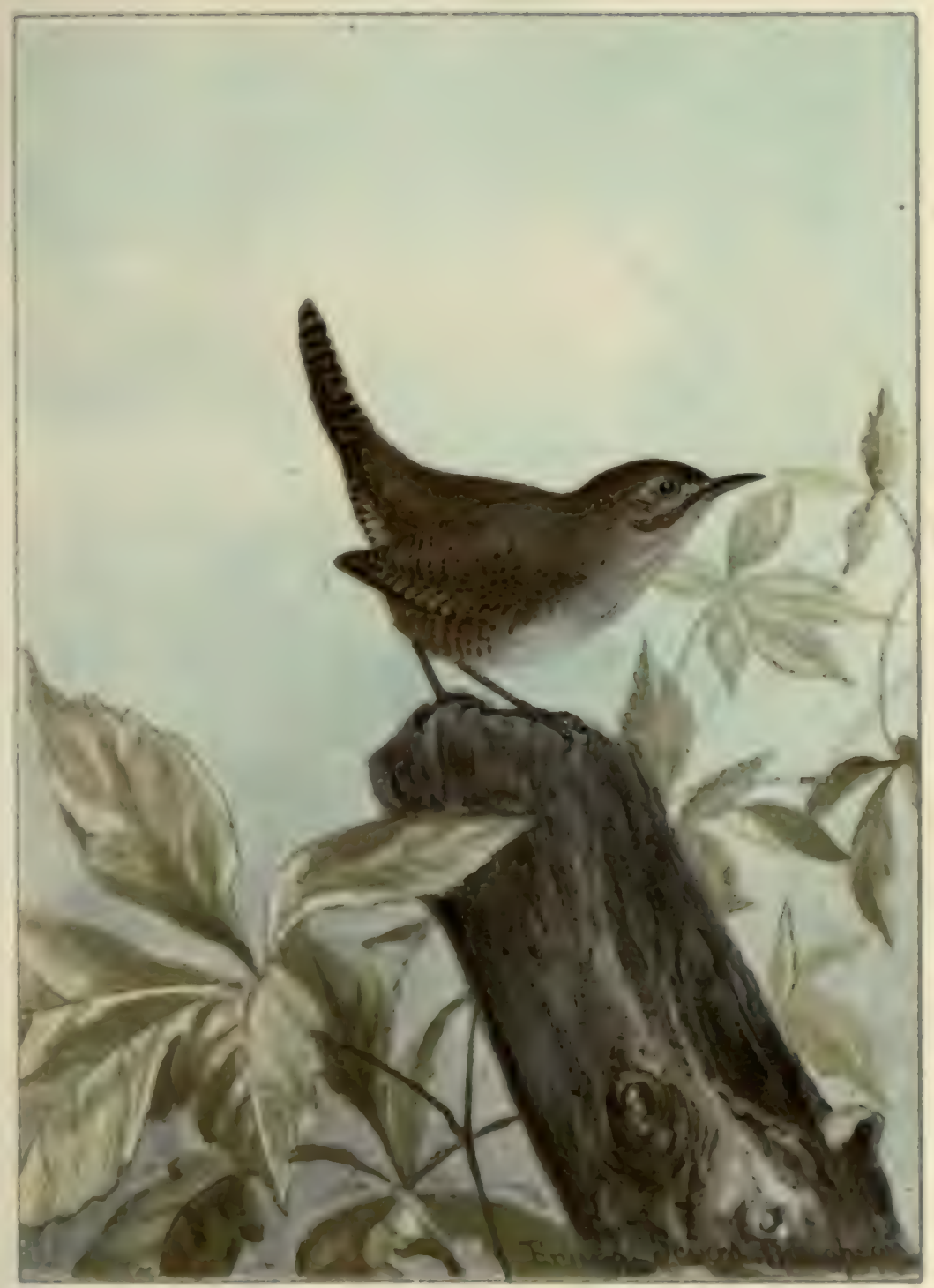

Puate IXvII.

PAOT 175.

\section{HOUBE WREN.}

Length, 5.00 inches. Upper parts brown, marked with black and grayish; ander parts graylah white. 

alout Mray 1, and its eggs are laid about the 20th of the month. They are white, speckled or spotted with cinna. mon and reddish brown.

The Maryland Yellow-throat is an abundant inhabitant of thickets and bushy undergrowths, readily iden-

\section{Maryland} titied by his black mask and yellow Yellow-thront, breast, nervous activity, and characterGeothlypia trichas. istic notes. Some birds must be apPlute LXIY. proached with caution, but nothing save an actual attack upon his home will eause the Yellowthroat to leave its shelter. Hopping from limb to limb, he advances to the border of the thicket, then retreats to it deptlis, all the time uttering an impatient chack, chit, or pit, and, if forced to $\mathrm{fly}$, he goes only to the next clump of bushes.

The Yellow-throat's somewhat explosive song is so easily set to words and so variable that there are many versions of it. It is described as whitititee, whitititee, mhitititee; rapity, rapity, rapity, rap, or witch-e-scee-o, witch-e-acee-o, witch-e-inee-o. Mr. Burroughs says he has heard birds whose notes sounded like the words "Which way, sir?" and I have heard some who seemed to say "Wait a minute."

To this the Yellow throat sometimes adds a flight song, which is a miniature of the Oven-tird's aërial serenade. It is generally adderl to his usual song, and is unst often heard late in the senson at evening, when the birl may be seen springing into the air above his bushy retreat.

The Yellow-tluroat arrives from the South about May 1 , and remains until the middle of October. Late in May a bulky nest of grasses, strips of hark, and dead leaves, lined with finer materials, is built on or near the ground. The three to five eggs are white, rather thinly speckled with reddish brown. Often an egg of the Cow. 
bird will be found in the nest, Yellow-throats being one of the birds most frequently chosen by the Cowbird as foster-parents.

The Chat is the largest of the Warblers, and so unlike them, or any other birds, in disposition that if classificaYellow-breasted Chat, tion were based on character, the Chat Icteria virens.

Plute LXV. would surely be placed in a family by itself. The Chat's peculiarities are numerous, but are most evident in his song. Many times I have sat, note-book and pencil in hand, trying to express in words the song of a Chat singing in a neighboring thicket, but I have never succeeded in putting on paper anything which would convey an adequate idea of the bird's remarkable vocal performances. Of others who hare attempted the same task, I think Mr. Burroughs comes nearest to interpreting the bird's strange medley. He says: "Now he barks like a puppy, then quacks like a Duck, then rattles-like a Kingfisher, then squalls like a fox, then caws like a Crow, then mews like a cat. . . C - r-r-r-r-r-whrr-that's. it-chee-quack, cluck, yit-yit-yit-now hit it - tr-r-r-r-when-caw-caw -cut, cut-tea-boy-who, who-mew, mew." You may be pardoned for doubting that a bird can produce so strange a series of noises, but if you will go to the Chat's haunts in thickety openings in the woods, or other bushy places, and let him speak for himself, you will admit that our alplabet can not do him justice. To hear the Chat is one thing, to see him guite another. But he will repay study, and if you will conceal yourself near his home you may see him deliver part of his repertoire while on the wing, with legs dangling, wings and tail flapping, and his whole appearance suggesting that of a bird who has had an unfortunate encounter with a charge of shot.

But if the Chat's song is surprising when heard during the day, imagine the effect it creates at night when 


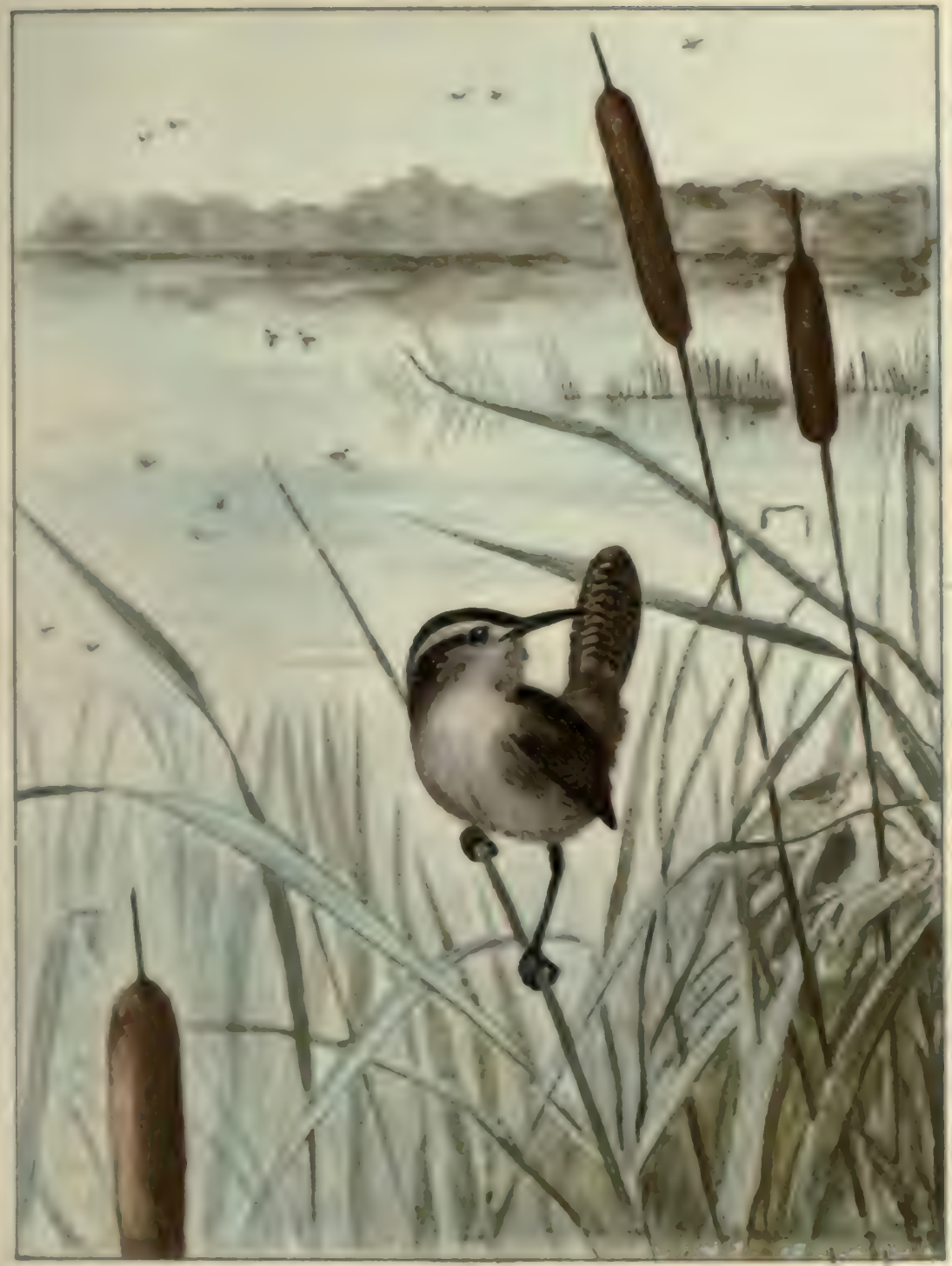

Pzate LXIX.

\section{LONG-BILLED MARBE WREN.}

Page 177.

Length, 5-20 inchea Upper parts brown, black, and white, a white Une over eye; under parts white, sides brownish. 

he has the stage to himself, for he is one of our few birds who sing regularly and freely during the night, moonlit nights being most often selected.

The Chat is a rather southern bird in its distribution, heing found north of Connecticut only locally and rarely. It winters in the tropice, coming to us about May 1 and departing early in September. Its well-made nest of grasses, leaves, and strips of bark is generally placed in the crutch of a sapling within three feet of the ground. Its three to five egns are white, rather evenly speckled and spotted with reduish brown.

\section{Turasners, Wress, etc. (FAMILY Troolodytida.)}

The Enstern representatives of this family are apparently too unlike to be classed in the same group, but when all the two hundred members of the family are studied, it is evilent that the extrenes are connected by intermediate speries possessing in a degree the characters of both Wrens and Thrashers.

The Catbird belongs to the subfamily Mimina, which contrins also the Mockinglirds and Thrashers, numberGatbind, ing some fifty species, all being restricted to North America.

carolinensis. The Catbird is one of the most familiar feathered inhahitants of the denser shrubbery about our lawns and gardens. The sexes are alike in color, both heing slaty gray, with a black cap and tail, anil lirick-rel under tail-coverts. They arrive from the South about A pril 29, and remain until October. Their nest is usually placed in thickets, shrubbery, or heavily foliaged trees, and the deep greenish blue eggs are laid the fourth week in May.

It is unfortunate that the Catbird's name should have originated in his call-note rather than in his song. The 
former is a petulant, whining, nasal tchay, to me one of the most disagreeable sounds in Nature, and so unlike the bird's song that he seems pussessed of a dual personality. The Catbird's song, from a musical standpoint, is excelled by that of few of our birds. His voice is full and rich, his execution and phrasing are faultless; but the effect of his song, sweet and varied as it is, is marred by the singer's too evident consciousness.

The Catbird's relative, the Mockingbird, is an abundant inhabitant of the southern United States from Vir-

Mockingbird, ginia to California, and ranges southMimus polyglnttos. ward into Mexico. In the Eastern

Plate LXVI. States it is not common north of southern Mlinois and Virginia, but in summer it is found in small numbers as far north as Massachusetts, where a few pairs breed each season. It is exceedingly domestic in its habits, and in the South there are few suitable gardens, either in the town or country, which are not inhabited by a pair of Mockingbirds.

The power of mimicry for which this bird is celebrated has, I think, been unduly exaggerated, and the fact that its usual song contains several notes resembling those of other species doubtless in part accounts for its much overrated ability as a mimic. It is unnecessary, however, for the Mockingbird to borrow the notes of other birds, for his own song places him in the front rank of our songsters. It is delivered with a spirit and animation which add greatly to its attractiveness. The Mockingbird does not sing between mouthfuls, as do the Vireos, or quietly from a perch, like the Towhee or Thrasher; he frequently changes his position, hopping from place to place, making short flights, bounding into the air, and displaying the white markings of his wings and tail, as though it were impossible for him to give expression to his emotion through the medium of voice alone. During 


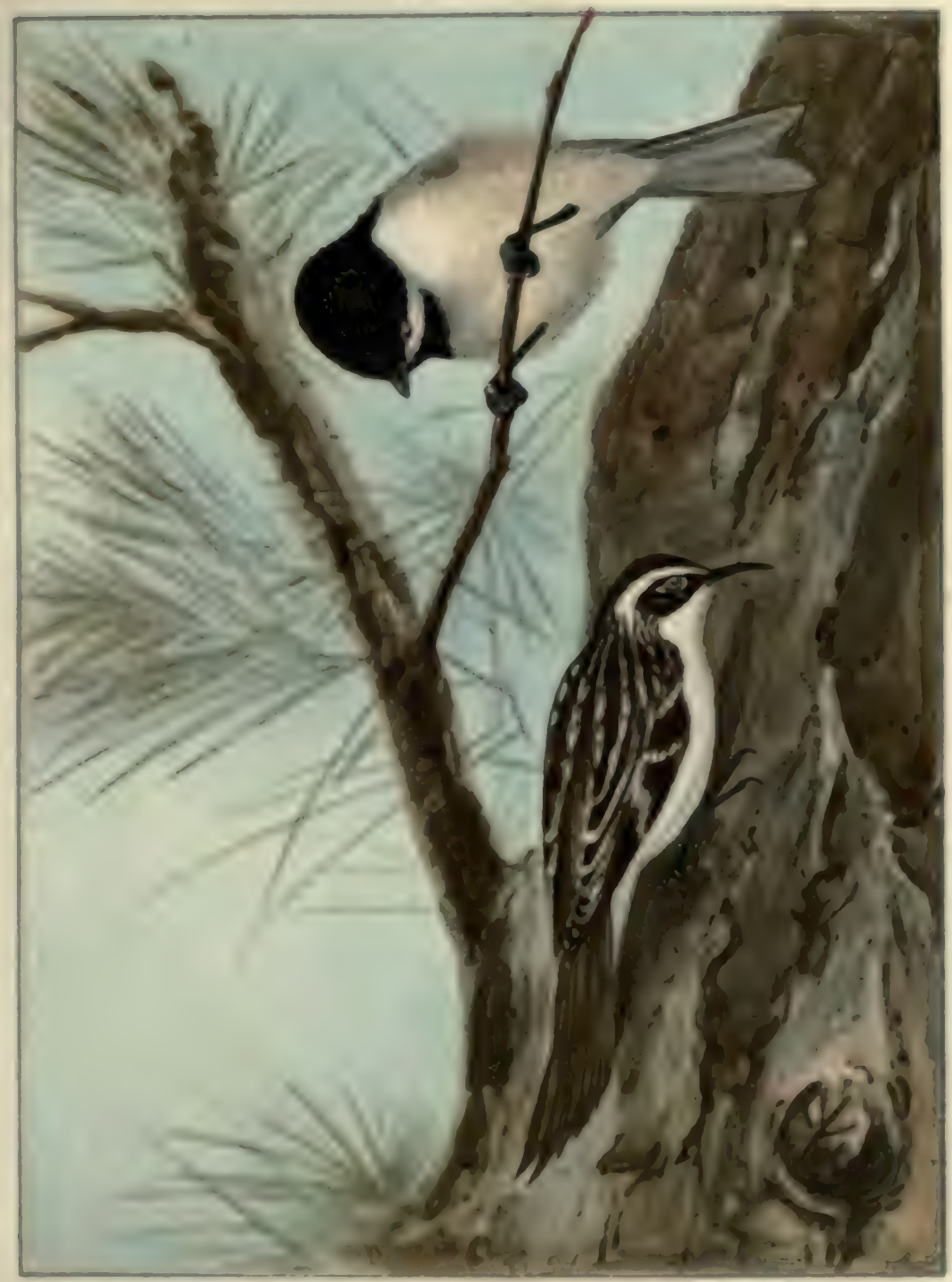

Puatx LXX.

OHIOKADEL.

Pagrs 178, 179.

Length, 5.25 Inobea Orown and throat black; cheaks white; back gray; belly white, washed with brownish.

BROWN CREEPER.

Langth, 6.65 inchea Upper parts brown, rusty, and whlte; under parts white. 

moonlight nights of the nesting serson, Mockingbirds sing all night. They are then less active, and, mounting to some favorite perch, often a chimney top, flood the still air with entruncing melody.

Like the Catlird and Mocker, the Brown Thrasher or Brown "Thrush" inhalits thickets and undergrowth.

\section{Brown Thrasber,} Hurgarhyochua rufius.

Plate L.XFIt.

He is, however, a inuch less domestic bird, and prefers l.rushy pasture lots and wayside hedges to lawns or gardens. IIe arrives from the Suth the latter part of $\mathrm{A}$ pril, and often remains until late in October. The nest is built ahout May 15, and is placed on the ground or several feet above it. The eggs are bluish or grayish white, thickly, evenly, and minutely speckled with cinnamon or reddish brown.

As a songiter I should rank the Thrasher between the Mocker and the Catbird. His song is less varied and animated than the Mocker's, and while his technique may nit excel that of the Catbird, his song, to my mind, is much more effective than the performance of that accomplished musician. Mounting to the topmost limb of a tree, he sings unintermptedly for several minutes. The notes can be heard for at least a third of a mile, ringing out clear and well defined above the medley of voices that form the chorus of a May morning.

The intense vitality which characterizes the life of birils finds its highest expression in the Wrens. Perpet-

Fouse Wren,

Truploclyea un lien.

Plate L.XFIII. ual motion alone describes the activity of these nervons, excitable little creatures. Repose seems out of the question; as well expert to catch a weasel aslecp as to find a Wren at rest.

In his morements, song, and nesting habits our House Wren exhibits the characteristic traits of his family. He is ever hopping. flitting, hobbing, or bowing, pausing 
only long euough to give voice to his feelings in fidgetty, scolding notes, or an effervescing, musical trill, with the force of which his small body trembles. It is a wonderful outburst of song, and the diminutive singer's enthusiasm and endurance are even more remarkable. The song occupies about three secouls, and I have heard a Wren, in response to a rival, sing at the rate of ten songs a minute for two hours at a time.

The House Wren nests in almost any kind of suitable hole or cavity, and will frequently take possession of a bird box, if the House Sparrows have not already set up a claim to the same property. To prevent intrusion from the Sparrows, the entrance to the house should be made not larger than a quarter of a dollar. Whatever be the site the Wrens select, their surplus energy is employed in completely filling it with twigs, half a bushelful being sometimes brought with endless pains. The nest proper is composed of dried grasses, and is placed in the center of this mass. Even in egg-laying the exhaustless vitality of $W$ rens is shown, as many as six or eight eggs being deposited. In color they are uniformly and minutely speckled with pinkish hrown.

The House Wren arrives from the South late in April and remains until October. Shortly before its departure in the fall a Wren comes from the Winter Wren, North that resembles the House Wren Troyludytes hiemalis. in appearance, but is smaller and has the under parts pale brown, the breast and belly being finely barred with a darker shade of the same color. This is the Winter Wren, a bird that nests from northern New England northward and southward along the crests of the Alleghanies to North Carolina. It remains with us in small numbers throughout the winter, returning to its summer liome in April. Mr. Burroughs writes of the Winter Wren's song as a "wild, sweet, rhythmical 


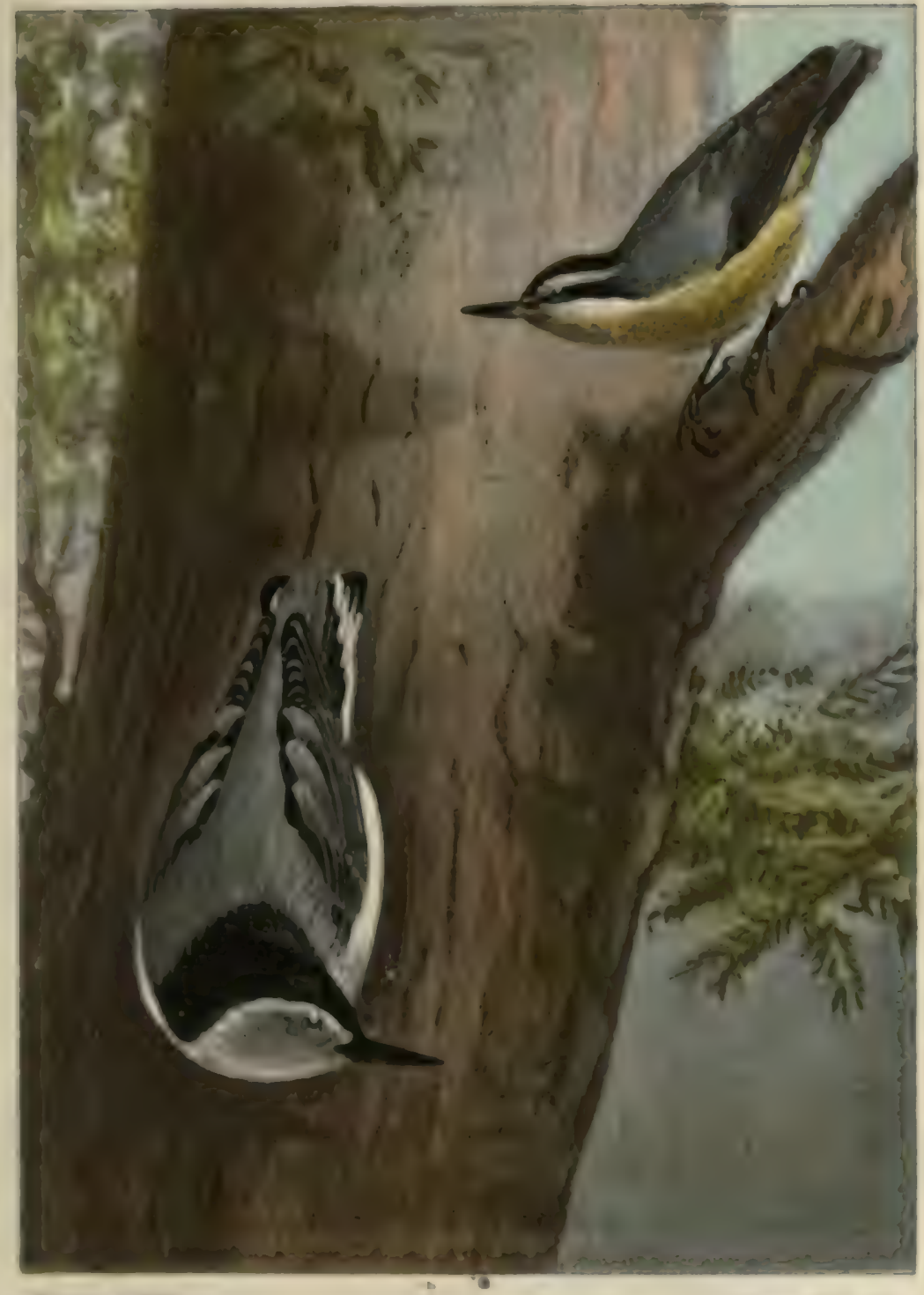

Pratr LXX.

PAOm 180, 181.

\section{RED-BRFASTED NUTH.ATH.}

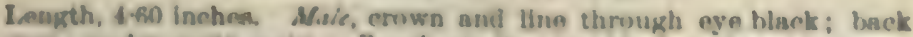
Rnay; under parts rusty. Fomole, simular, but black replacerl by gray.

WHITE-BREASTED NUTHATCH.

Lensth, 6-05 Inchne. Male, erown black; lavek gray; face and under parta white. Fonale, siailar, but erown alaty. 

calence that holds yon entranced," but while with us the hiral's only note is an inpatient chimp, chimp, suggesting the Song Sparrow's eall-note.

The Camolina Wren is a more southern bird than the House Wren. It is of only local distribution north 11 Carolina Wron, southern New Jersey, and is rare? Mrryollewina found north of the vieinity of New buducievinns. York city, where it appears to be incrensing in numbers and is found throughout the year. This Wren is half an inch longer and decidedly heavier than the llouse Wren; its upper parts are bright cinnamon, its under parts washed with the same color, and a conspicuous wlite line passes from the bill over the eуe.

The Carolina Wren is an exceedingly musical bird, and its houl whistle I calls are among the most characteristic birl notes in the South. They are numerous and varier, the most common resembling the svllables whee-

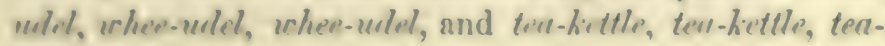
kettle.

The haunts of most marsh-inhabiting birds are as sharply defined as the limits of their ranges. The LongLoag-billod billed Marsh Wren is not known in Ranh Wron, the East north of Masencliusetts, but I ciafuehar. minatris. would as soon expect to find one of Mase I.XIX. these birds in Greenland as out of a mash. They arrive from the sonth early in May and remain until Oetolver, living in marshes where cat-tails grow, to which they may attach their bulky, glolular nests of roeds and grasses. With the superabundant viger of Wrens they builal more wests than they can possibly occupy, and many will he cxamined before the five to six dark hrown ergers nre found.

The Mansh Wren is quite as active and irrepressible as the other niembers of his family. His call is the cus- 
tomary scolding cack; his song, a bubbling, trickling tinkle that can not be called musical, but to my mind is indescribably attractive. It is often sung in the air, and in marshes where Wrens are abundant bird after bird may be seen springing a few feet above the reeds, singing his song, and then dropping back again.

\section{Creepers. (Family Certhidda.)}

Of the twelve known members of this family, the Brown Crceper is the only one inhabiting the New

Brown Creoper, Certhia familiuris

Plate LXX. World. It is a northern bird, breeding at sea level only from Maine northward, but extending southward in the Alleghanies to North Carolina. Several western races are found in the Rocky Mountain region and Sierra Madres. Our eastern bird migrates southward late in September, and from that date until April it may be found from Massachusetts to Florida.

The Creeper, like a Woodpecker, never climbs head downward, but, using his stiff, pointed tail-feathers (see Fig. 36 ) as a prop, winds rapidly up the trunks of trees in his apparently never-ending search for insects' eggs and larvæ hidden in crevices in the bark. If the Wrens are the most active birds, the Creeper is the most diligent. Except when it was stopping to secure some tidbit, I can not remember seeing a Creeper resting. He usually begins at the base of a tree and climbs in a serious, intent way for a certain distance, and then, without a moment's pause, drops down to the bottom of the next tree and continues his search.

The Creeper's only notes while with us are a thin, fine squeak; but Mr. Brewster tells us that during the nesting season he has an exquisitely tender song of four notea 


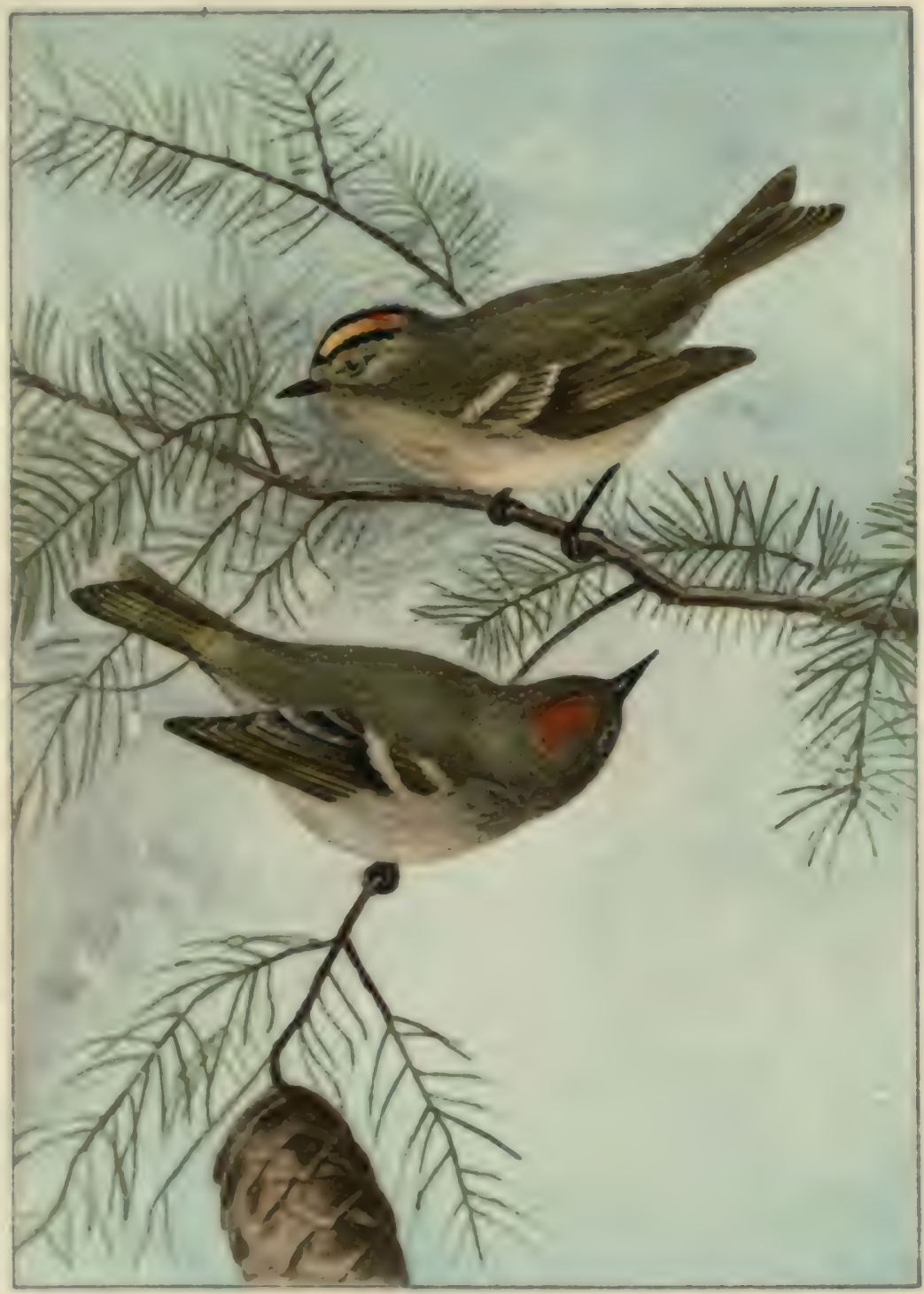

PLATE LXXII. GOLDEN-CROWNED KINGLET. PAaEs 181, 182.

Length, 405 inches Male, crown orange, yellow, and black; back olive-green ; under parts whitish. Female, similar, but crown without orange.

RUBX-CROWNED RINGLET:

Length, $4-10$ inchea $A$ dwll mak, arown-patch ruby ; back ollve-green; anclor parts whitish. Adult fomale and young, similar, but no errivn:pertah. 



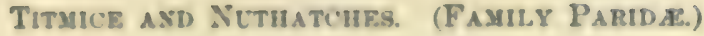

Comparing the Titmice with the Nuthatches, the former may le desicribed us short-billed birds with long tails who do not ereep, the latter as long-billed birds with short tails who do ereep. The two groups are, in fact, quite distinct, and by some systematists are placed in separate families.

The Titmice number some seventy-five species, four of which are found in eastern North America. The

Crisakadeo,

Purue atr...jullue.

Plate L.X. commonest and most generally distributeil is the Black-erpped Chickadee, which is found from Labrador to Maryland and in the Alleghanies southward to North Carolina. Fartier south it is replaced by the closely alliel Carolina Chickadee.

Throughout the greater part of its range the Chickadee is found ut all sensons, lut it is less common in the middle and southern New England States in summer than in winter, and is most numerous during its migration in October.

It is with winter that these merry little black and white milgets are generally associated. Their tameness, quaint notes, and friendly ways make them unusually companionalule birds; one need not lack for society when Chickmlees are to he found. Many of their notes are espocially conversetional in character, and in addition to the faniliar chickadee call, they have a high, sweet, plaintive two- or three-notel whistle.

The Chickadee nests about the middle of May, selecting some suitable carity or making one for himself in a decayed trunk or liml and lining it with moss, plantdown, and feithers. Tlie egers, five to eight in number, are white, spotted and speckled, chiefly at the larger end, with cinnamon or reddish brown. 
The Tufted Titmouse is a more southern bird than the Chickadee and is rarely found north of northern New Jersey, where, however, it remains Tufted Titmouse, throughout the year. It is six inches Parusbicolor. in length, gray above, whitish below with a black forehead, reddish brown sides, und a conspicuous crest. Its usual call is a whistled peto, peto. peto, which it will utter for hours at a time. It has also a de-de-de-de call, suggesting the Chickadee's well-known notes, but louder and more nasal.

With no especial structure other than slightly enlarged toe nails, the Nuthatches still differ markedly from other White-breasted birds in the ease with which they run Nuthatch, up or down tree trunks. The tail is Sitta carolinensis. short and square and is not used in Plate LXXI. climbing. The bill is rather slender, but proves an effective instrument in removing insects" eggs and larvæ from crevices in the bark and even in excavating a nesting hole in some decayed limb. Several species also use it to crack or "hatch" nuts after they have wedged them in a convenient crevice.

Of the three species of Nuthatches found in eastern North America the White-breasted is the most common and generally distributed, being a permanent resident from Florida to northern New England. Like many resident birds, it nests early, the five to eight eggs being deposited about April 20. They are white, thickly and evenly spotted and speckled with reddish brown and lavender.

This Nuthatch's usual call-note is a loud yank, yank, while its song is a singular, tenor hah-hah-hahhah-hah.

The Red-breasted Nuthatch is a more northern bird than its larger, white-breasted cousin. At sea level it nests from Maine northward, but in the higher parts of 


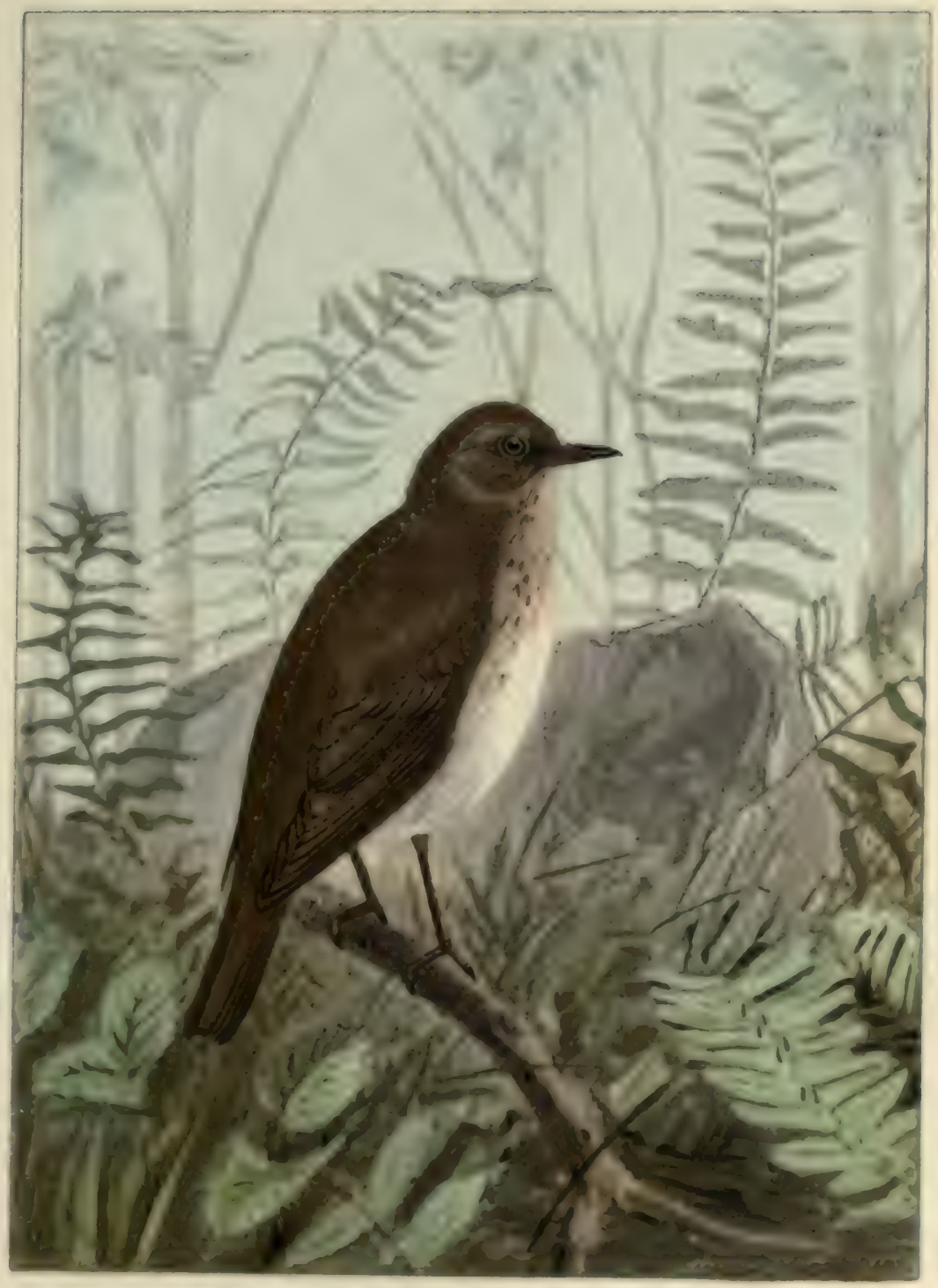

Puate LXXII.

VERRY.

PaGe 183.

Length, 7.50 inches. Opper parts, wings, and tall unlform light einnamon; breast buffy, Ught marked with ofnnamon; belly white; sides graylah. 

the Alleghanies it breeds as far southward as North Carolina. It comes to us from the north early in Septem-

\section{Rod-breasted} ber, and in the winter may be found in

Natsocth, varying numbers from Mrssachusetts to sittramidensio. the Grulf States. Its call-note is Plate LXXI. higher, thinner, and more drawled than the vigorous yunk, yank of the White-breasted Nuthatch, and suggests the sound produced by a penny trumpet.

Kinalets, Gastoatcherg, etc. (Family Sylviida.)

Of the three subfamilies included in this family we have representatives in eastern North America of only two-the two King?'ets of the subfamily Regulince and the Blue.gray Gnatcatcher of the subfamily Poliuptiline. The Gnatcatcher is a southern bird, occurring only locally or as a straggler north of Maryland. The Kinglets are both more northern in their distribution.

The Golden-crowned Kinglet nests from the northeru tier of States northward and southward along the Goldon-erowned crests of the Alleghanies to North CarKinglot, olina, In its autummal migration it Rerpulue entraps. rexches the vicinity of New York city

Plute LXXII. about September 2), and during the winter my be found in varying numbers from Maine to Florida.

The Golden-crown flits about the terminal twigs in its search for insect food and reminds one somewhat of the smaller, tree-inhabiting Warblers in habits. Its call is a fine $l i, l i$, one of the highest and least noticeable notes uttere. hy birds. Its song, which is rarely heard except in its nesting range, is described by Mr. Brewster as beginning with a succession of five or six tine shrill, high-pitched, 
somewhat faltering notes, and ending with a short, rapid, rather explosive warble.

The Ruby-crowned Kinglet is a more northern bird in summer and a more southern bird in winter than the Golden-crown, rarely being found at the latter season north of South Carolina. Throughout the Middle States it oc-

Ruby-crowned curs as an abundant spring and fall miKinglet, grant, passing northward from April 10 Regulus calenu'mla. to May 10 and southward between SepPlute LXXII. tember 20 and October 20. The Rubycrown resembles the Golden-crown in habits, but is more active. Females and young males lack the ruby crownpatch, but their white eye-ring, impatient, wrenlike little note, and manner of nervously twitching their wings are characteristic.

Taking the small size of the bird into consideration, the Ruby-crown's song is one of the most marvelous rocal performances among birds. As Dr. Coues remarks, the sound-producing organ is not larger than a pinhead, and the muscles that move it are almost microscopic shreds of flesh; still, the bird's song is not only surpassingly sweet, varied, and sustained, but is possessed of sufficient volume to be heard at a distance of two hundred yards. Fortunately, the Ruby-crown sings both on its spring and fall migrations.

\section{Threshes, Bluebirds, Etc. (Family Turdid fe.)}

On the basis of certain details of structure Thrushes are generally assigned highest rank in the class Aves. Without pausing to discuss the value of the characters on which this classification is made, there can be no question that from an æsthetic standpoint the Thrushes possess in a greater degree than any other birds those qualifications which make the ideal bird. There are many birds with 


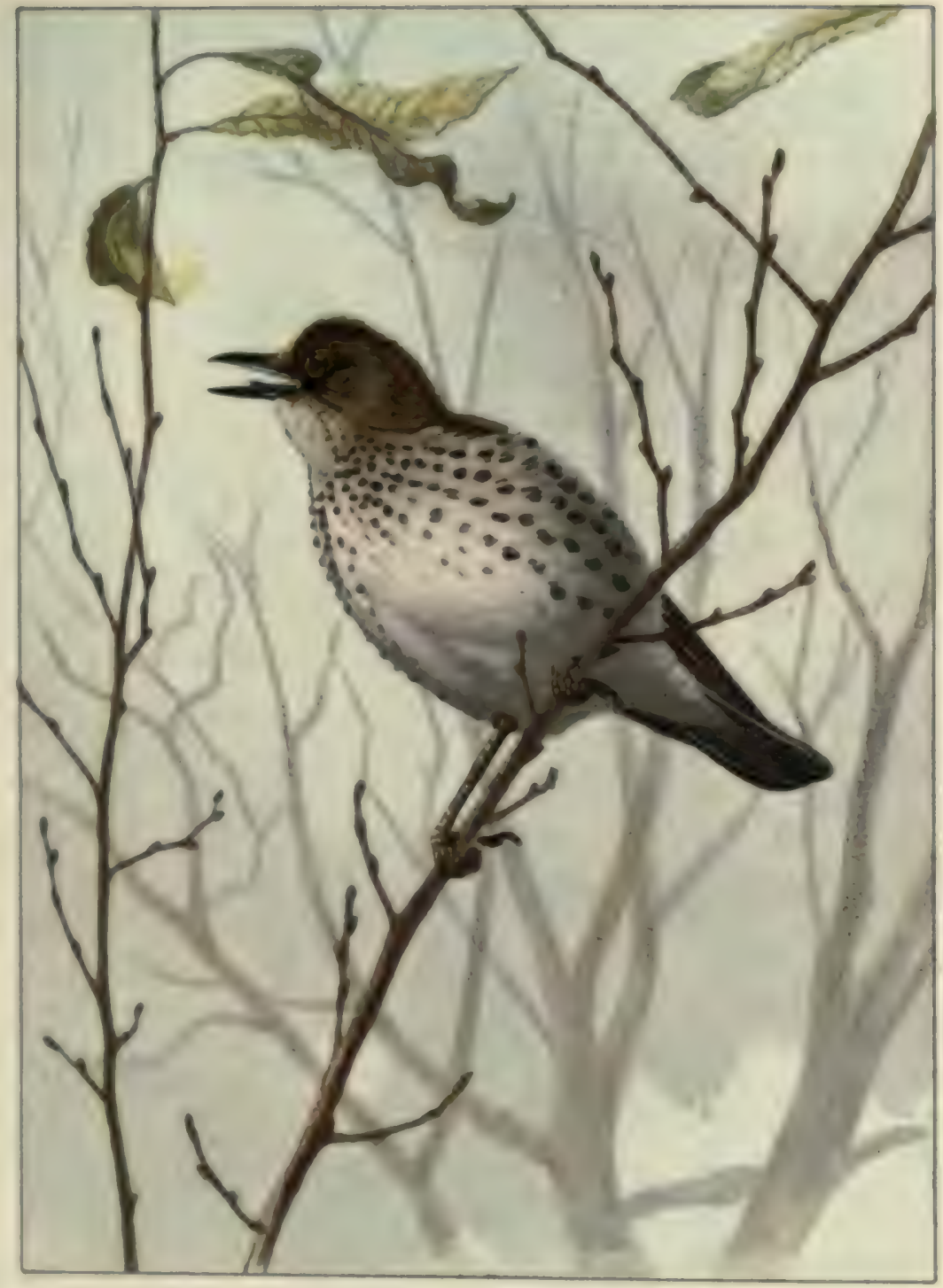

Plate LXXIV.

WOOD THRUSH.

Paan 184.

Langth, 8.30 Inchea. Upper parts bright, rusty cinaamon, brightest on back and emwn; under jarts white everywhere, except center of belly, with large, rounded black spota. 

brighter plumage, more striking voices, and more interesting habits, but there are none whuse bearing is more distinguished, whuse songs are more spiritual. The brilliant Il umminglirds and Tanagers excite our admiration, but the gentle, retiring Thrushes appeal to our higher emotions; their music gives voice to our nohlest aspirations.

Five of the true Thrushes of the genus Turdus are found in e.sitern North America. Three of them may le mentioned here-the Veery, Wood Thrush, and Her. mit Thrush $-\mathrm{a}$ peerless trio of songsters. The Veery's mysterious voice vibntes through the air in pulsating eircles of song, like the strains of an Eolian harp. The Wood Thruslis notes are ringing and bell-like; he sounds the matin and resper chimes of day, while the Hermit's hymn echoes through the wools like the swelling tones of an organ in some rast cathedral.

But it is impossible to so describe these songs that their charm will be understood. Fortunately, all three lirils are aluundant, and a brief account of their haunts and habits will enable any one to find them.

The Veery, or Wileon's Thrush, winters in Central Ameriea, and nests from northern Illinois and northern

Veery, New Jersey northward to Manitoba and

Tumbur furemens. Newfoundland and southward along the

Plute LXXI1. Alleghanies to North Carolina. It comes to us in the spring, about May 1, and remains until Septemler 15. Near the middle of May it begins to build its nest, placing it on or near the ground. Its eggs are greenish blue, and resemble in color those of the Wood Thrush, hut are slightly smaller.

The Veery's favorite launts are low, damp wonds with an abundant undergrowth. It is a more retiring birl than the Wood Thrush, and is moly seen far from tracts of woodland. It is to be distinguished from our other Thrushes by the unifurm cinnamon color of its 
npper parts, faintly spotted breast, and particularly by its notes.

The Veery's characteristic calls are a clearly whistled whèe-o or whèe-you, the first note the higher, and a somewhat softer too-voee or teweri, in which the first note is the lower. Its song is one of the most mysterious and thrilling sounds to be heard in the woods. Elsewhere I have described it as " a weird, ringing monotone of blended alto and soprano tones. ... It has neither break nor pause, and seems to emanate from no one place. If you can imagine the syllables vee-r-r-hu [or vee-ry] repeated eight or nine times around a series of intertwining circles, the description may enable you to recognize the Veery's song."

The Wood Thrush is a more southern bird than the Veery, breeding from as far south as Florida, northWood Thrush, ward to southern Vermont and MinneTurdus mustelinus. sota. It winters in Central America

Plate LXXIV. and reaches us in the spring, about A pril 30 , and remains until October 1 . Its nest is built about the middle of May, and is generally placed in a sapling some eight feet from the ground. The eggs are greenish blue.

The Wood Thrush is not such a recluse as the Veery. $\mathrm{He}$ is, it is true, a wood lover, and shares with the Veery his secludel haunts, but he seems equally at home in maples and elms about our houses, or even in the more quiet village streets. He is therefore more often heard than his mysterious relative, and, as a voice, is familiar to many who do not know the singer's name.

The call-notes of the Wood Thrush are a liquid quirt and sharp pit-pit. The latter is an alarm note, which, when the bird fears for the safety of its young, is uttered with much increased force and rapidity. It can be closely imitated by striking two large pebbles together. 


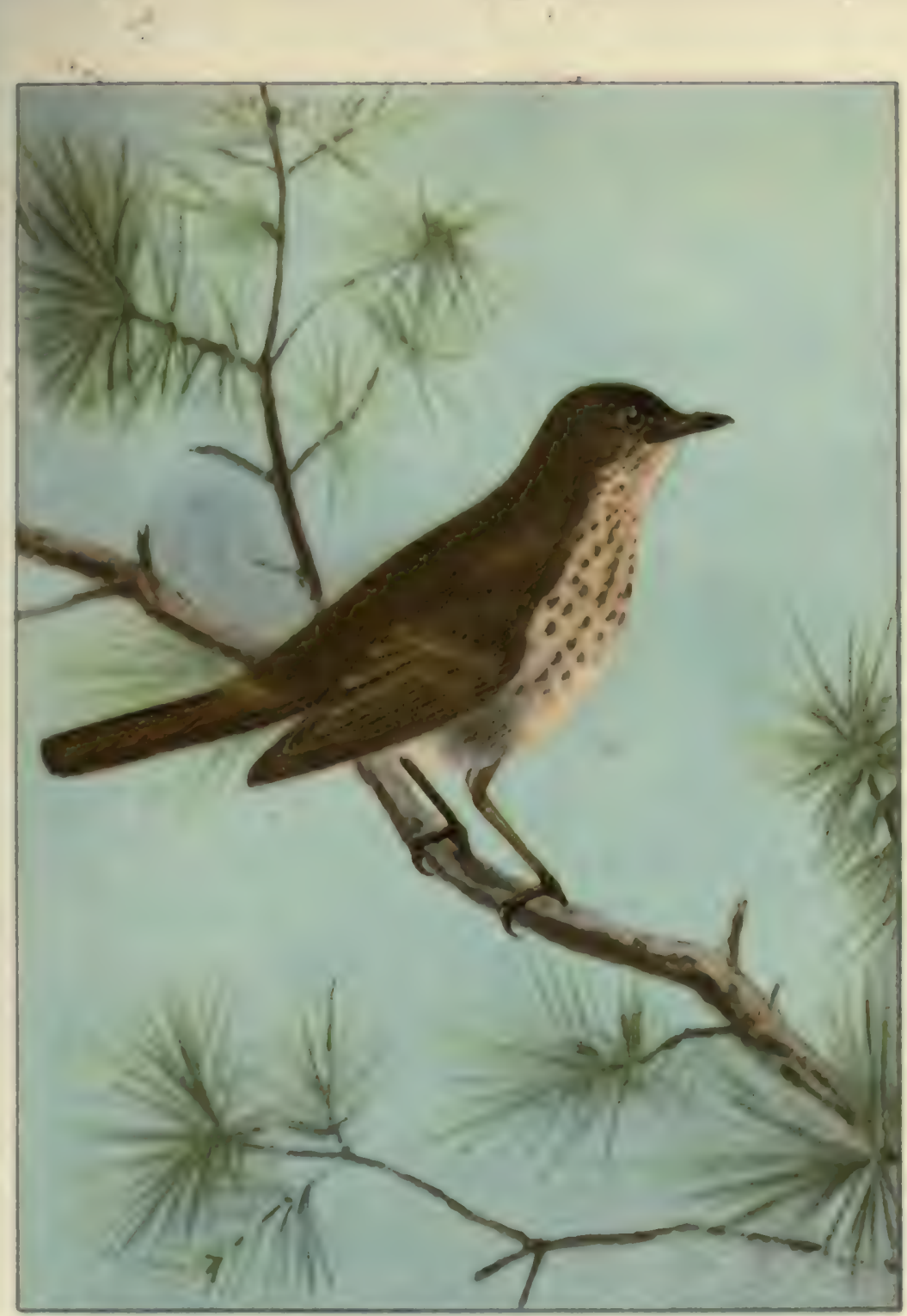

Prants LXXv.

Paas 185.

HERMTT THROSR.

Length, 7.15 inches. Upper parts and wings dark elnnamon-brown: tall bright roddiah brown; under parts white; brenst spotted with black; sides washed with brownlsh; belly white. 

The song of the Wood Thrush is wholly unlike that of the Veery. It opens with the flutelike notes,

$\therefore \therefore$

Come to me,

and is sung disconnectedly, being broken by pauses and by low notes, andible only when one is near the singer.

The Hermit Thrush is a more northern bird than either the Veery or the Wood Thrush. It rarely nests at

Hermit Thrush,

Twrulwo conuluach to pallavii.

Plate LXXV. sea level south of Vermont or northern Michigan, but in the higher portions of Massachusetts and on the crests of the Catskills and Alleghanies in Pennsylvania, it is also found breeling. It winters from southern Illinois and New Jersey southward to the Gulf, it being the only member of its genus to inhabit the eastern L'nited States at that season. Its spring migrations occur between April 5 and May 10, and in the fall we see it from October 15 to November 25, while occasionally it may winter.

During its migrations the Hermit Thrush usually frequents woollands, where it may often be seen on or near the ground. Like the Veery, it is a ground-nester, and its eggx, thongh slightly lighter in color, resemble those of the Veery and Wood Thrush in being plain, bluish green. When alighting, the Hermit has a characteristic labit of gently raising and lowering its tail, and at the same time uttering a low chuck. Sometimes it sings during the winter, in Florida, and also while migrating: hut if you would hear this inspired songster at his best, you must visit him in his summer home. The Hermit's song resembles that of the Wood Thrush in form, but it is more tender and serene. O spheral, spheral! O holy, holy! Mr. Burroughs writes the its opening notes, and there is something about the words which seems to express the spirit of heavenly peace with which the bind's song is imbued. 
It seems a long step from these gentle, refined Thrushes to their comparatively prosaic cousin, the famil-

Robin,

Merula migrutoria. place, and in March his cheery song is hymn in June. iar Robin... But the Robin las his quite as effective as the Hermit's

During the summer Robins are distributed throughout North America from the Gulf States and southern end of the Mexican tableland, northward to Labrador and Alaska. In the winter they may be found in numbers from Virginia southward, small flocks and single birds being occasionally met with as far north as Massachusetts. Robins are among our earliest migrants, appearing in the vicinity of New York city letween February 20 and March 1. Nesting is legun about April 15, the mud-lined nest and greenish blue eggs being too well known to require c'escription. Two, or even three broods may be raised. In June, the young of the first brood with some adult males resort each night to a chosen roost, often frequented by many thousands of birds.

The fall migration begins in September, lut the birds are with us in roving bands until December.

About the time that we first hear the Robin's ringing welcome to spring we may listen for the Bluebird's more

Bluebird,

Sialia sialis. gentle greeting. Doubtless the bird has been with us all winter, for Bluebirds winter in small numbers as far north as sonthern Connecticut, often living near groves of cedars, which offer them both food and shelter. In the Southern States they are far more abundant at this season, gathering in flocks containing hundreds of individuals.

The Bluebird is the first of our smaller birds to begin housekeeping, and early in April it may be seen pro-. specting about the site of last year's nest in a bird box or 
hollow tree, and the bluish white eggs will probab.y be laid before the middle of the month.

No birl's song is more associatel with the return of spring than the Bluebird's; nor is there a bird's note more expressive of the passing senson than the Bluckird's autumn call of für-azouy, für-away. 



\section{N D E X.}

Acanthis linarna, 146.

Aceipiter cooperi, 107. volox, 107.

Actitio mucularien 96.

Angialltis nemipalmaten 99. vociferm, 109.

A gelaius phoniceus, 182

A frreesive colontion, 4 .

Aigretre plames, 28.

Alsudida, 186.

Albatrom 18, 19.

Alecdinide 118

Ampolide, 181.

Ampolis cedrorum, 161.

Anatiden, 89.

Androulon, 82

Anhinger, 32.

Anseress 89.

Antroweomes vociforns 119.

Arehwoptery $x_{0}$ 8, 4, 18.

Ardes herolian, 91.

virescesa 92.

Anleiden 90.

Anin acel pitriana 109.

wilsonianus 110.

A uk, Groet, so.

Rasor-billed, 20.

A utte, $20,21,28,80$.

A vocet, 82, 23.

A rncottula, 81.

Bill, the a hand, 20.

a a moaical instrument 80 .

a a weapmon. 81.

coxual adornment of, 80.

uese of 80.
Birda altricial, 68. ancerton of, 2. beututy of, 9 . bill of, 30 . biography of, 78 characten of, 2 . colons of, 85. dimtrihution of, \&. econonsio value of, 6 . egyz of, 68 evolutinn of, 14.

fuet of, 27 .

fleld key to, $7 B$.

flighticn, 19.

grnce of, 10.

how to identify, $n$.

mating of, nis.

mental development of, 10.

migration of, 48

inusical powers of, 10.

nexts of, 65.

number of npecies of, 1 . place in Nature of, 1. preencial, 69. relation to man of, $B$. ecientifle value of, 5 . mones of, 11, 62. tail of. 2B.

copngraphy of, 74.

rnice of, 62

winew of. 17.

young of. 70 .

Bittem. A meriean, as.

Blackhird, Cmw, 18s.-

Relwinged, 182 -

Black hinla, 88, 180. - 
Bluebird, 49, 186.

-Bobolink, 16, 36, 87, 88, 54, 55, 60, 63, 134.

Bob-white, 86, 100.

Bonusa unbellus, 101.

Butaurus lentiginosus, 98.

Bubonidæe, 108.

Bull-bat, 118.

Bunting, Buy-winged, 140.

Black-throated, 155 .

Indigo, 68, 152.

Snow, 147.

Butcher-bird, 162.

Buteo boreulis, 106.

lineatus, 104.

Butter-bird, 185.

Buzzurd, Turkey, 104.

Buzzards, 8.

Call-notes, signiticance of, 63.

Canaries, 89.

Caprimulgidø, 117.

Cardinal, 158.

Cardinalis cardinalis, 153.

Carpodacus purpureus, 149.

Cassique, 23.

Cawowary, 19.

Catbird, 69, 178, -

Cuthurtes anra, 103.

Cathartida, 708.

Certhia familiaris americana, 178.

Certhiidæ, 178.

Ceryle alcyon, 114.

Shretura pelagica, 119.

Chambergo, 185.

Charadriidæ, 98.

Chat, Yellow-breasted, 172.

Chebec, 125.

Thelicion erythrogaster, 158

Chewink, 151.

Chickadee, 7. 8, 70, 179. -

Camlina. 179.

Chiply. 142.

Rod-cappod, 146.

Winter. 14k.

Chondestes erammacun, 154.

Chordeilus virginianus, 118.

eircus hudsonius, 106.
Cistothorus palustris, 177.

Clamatores, 122.

Clape, 116.

Clivicola riparia, 159.

Coccyges, 112.

Coecyzus americanus, 112. ery throphthalinus, 113.

Colaptes auratus, 116.

Colinus virginianus, 100.

Color and age, 36.

and climate, 39.

and food, 89.

and haunt and habit, 41.

and $\operatorname{sex}, 45$.

Colors of birds, 35.

Columbro, 102.

Columbidx, 102.

Contopus virens, 126.

Coot, 27, 28, 94 .

Cormorants, 69.

Corvida, 128.

Corvus americanus, 128.

Cowbird, 137.

Creeper, Brown, 16, 25, 178.

Creepers, 6, 15, 16, 178.

Crossbill, A merican, 147.

Crow, American, 128. -

Crow-duck, 94.

Cuckoo, Black-billed, 113.

Yellow-hilled, 7, 112.

Cuculidx, 112.

Cyanocitta cristata, 180.

Deceptive coloration, 44.

Dendrocolaptidær, 32.

Deudroica æstiva, 168.

coronata, 168.

virens, 168.

Dickcisuel, 155.

Dircetive colors, 44.

Diving Birds, 84.

Docimastes, 31.

Jolichony x ory zivorus, 184.

Dove, Curolina, 102.

Mnurning. 102.

Dryobater pubescens medianus, 116. villosus, 115.

Duck, Black, 89. 
Jluok, Bromalbill, 00.

Inuthelicul. se.

Canverbouks, so.

Eiilur. 90.

6) Kiquew, 90.

Beslitureal. vo.

Buddy, vo.

Scoup, 90.

Wood, 89.

[Ducke, $20,81,82,28,28,80,86,67$.

Eumple, Beld, 100.

kixise of binla, 68

Eigreh W' hite, yI.

Euppidonax avisimea, 128.

Eimu. 18, क0, 70.

Ereusetos pueillua, 98.

Eurnxervo, 81.

Yialso aparverion 106.

falcenide, 104.

fiseh the so bande, 29.

a weaponan 89.

ettects of ue aad disure of, 27 .

menanal change in serueture of, $2 \%$.

toces of, 87 .

Biold-allex, 72

Fiuch, Girna, 140.

Lark. 134.

Purple, 20, 149.

Finchen 42, 1 as.

Firobind, 181.

Fiah IInewts, 66.

Vlaviingn, 22, 29.

Flieker, ca 118.

Ply cateher, Arianns Crested, IIL.

('reated, 8Q 182

(imat Crowted, 12s.

Least. 12s.

Fl, -at. liess, 6, 85, 46, 121.

Prowe IHols, 5, 19

Progthlo iso.

Fulles anericana, 34

Gialmasomen camlinenate, 17s.

Q iallinase, bees

Govilinaere delienena, 9:

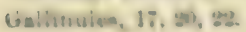

Ginzicta 82.

Geotblypin triches, 171.

Glucial period, B9.

Guatealeher, Bluv-gray, 181.

Goldtuch, 148.

Goove, Caruads, 94.

Grackle, Bronzed, 128.

P'usple, 188.

Grobe, Pied-hilled, 81, -

Grutes, 18, 80, 81, 28, 25, 27, 84.

Grombeak, Cardinal, 86.

I'ine, 148.

Rowe-breasted, 86, 180.

Grouse, Kutfed, 82, 101-

Grouve, 18, 19, 28, 87, 98, 86, 41, 62.

Gull, Ilerring, 86.

Gullu, 9, 67.

Inliwetua levcocephalus, 108.

llangnerh, 181.

Harporhy neloss rufus, 175.

Llawk, Chicken, J04, 106.

Cooper's, 8, 104, 107.

Finh, 14, 29, 107.

Ilen, 104.

Mansh, 64, 108.

Ked-ahouldered, 104.

Ked-tailed, 106.

Sharp-ahinnod, 8, 104, $10 \%$.

Sparrow, 106.

Ilawka, \%, 8, 29, 86, 44, B8, 66.

Hell-diver, 84. -

llerodiones, yo.

Heron, Bluek-erowned Night, 92.

Great Blue, 21.

Little Groen, 92

Saowy, 91.

Ilemea 20.

Hligh-hole, 68, 70, 116.

Hirundiaiden, 156.

Iloatzin, 17.

Ifuis-hınd, 8 s.

Humming-bird, A rocot, 81

Ruhy-thrmated, 120.-

sickle-billed, 81.

Siphon-billed, \&s.

sinell-billed, $\mathbf{s 1 .}$

Tooth-billed, s2. 
Hummingbirds, $5,6,14,18,23,25,31$, Microrhynchus, 31 . $42,67,69,70,120$.

IUis, Scarlet, 39.

Icteria virens, 172.

Ictcridæe, 130.

Icterus galbula, 181. spurius, 182.

Jacana, 24, 28.

Jay, Blue, 129.

Junco, 145.

Junco hyemalis, 145.

Juncos, 41, 44. -

Key to common birls, 75 .

Killdeer, 99.'

Kingbird, 122.

Kinyfisher, Belted, 114.

Kinglet, Golden-crowned, 181.

Ruby-crowned, 182.

Lantidıe, 162.

Lanius borealis, 162.

Lark, Horned, 41, 55, 126.

Prairie Horned, 127.

Laridøo, 86.

Larus argentatus smithsonianus, 86.

Lighthouses, 56, 57.

Limicolæ, 82, 95.

Longipennes, 86.

Loon, 85.

Loxis curvirostra minor, 147.

Macrochires, 117.

Malland, 89.

Man-o'-war Bird, 19.

Marsh Hen, 94.

Martin, Purple, 15\%, 161.

Mating of birds, 65 .

Meadowlark, 27, 44, 186.

Megascopв aвio, 110.

Melanerpes ery throcephalus, 116.

Melonpiza fasciata, 188. goorgiana, 189.

Ylergunsens, 82, 89.

Merula migratoria, 186.

Micropodidæ, 118.

Migration of birds, 48.

cause of, 59.

effects of changes of climate on, 59 .

extent of, 49.

highways, 55, 60.

manuer of, 54 .

nocturnal, 55, 56, 57 .

origin of, 58.

times of, 49 .

Mimus polyglottos, 174.

Mniotilta varia, 167.

Mniotiltidæ, 166.

Mockingbird, 174.

Molothı us ater, 187.

Molt, the, 87.

Momotus subrufescens, 25.

Motmot, 25.

Mud-hen, 94.

Myiarchus crinitus, 123.

Natural selection, 14, 15, 65 .

Nesting seazon, 64.

Nest of birds, 65 .

Nighthawk, 6, 23, 118 .

Notornis, 22.

Nuthatch, Red-breasted, 180.

White-breasted, 181 . -

Nuthatches, 6, 8. 7

Nycticorax nycticorax nævius, 92.

Opera-glass, 72.

Opisthocomus cristatus, 17.

Oriole, Baltimore, 181 -

Orchard, 87, 181, 182.

Orioles, 42, 44, 55, 180.

()rtolan, 185.

Oscines, 122.

Ukproy, American, 107.

Ostinops, 28.

Ostrich. $8,18,19,27,29,69,70$.

Otocoris alpestris, 126.

Oven-bird, 170.

Owl, Barn, 8.

Barred, 111.

Great Horned, 110.

Long-eared, 110.

Sereech, 41, 110. 
Owl, short-eared, 209.

Snowy, 14.

On ls, 7, 8, 80, 65, 108

Ox-aye, y8.

I'aludicolar, 98.

Pandion halisestus earolinenala, 107.

Paricis. 179.

Parrota, 8, 80, 20, 81, 89, 40.

Partridge, 18, 67, 100, 101.-

Parus atricapillea, 179.

bicolor, 180.

Pnomer donseticus, 141.

Panerolla illecen 14.

Paseores 181.

Pomerina cyanea, 152

Peubody-bird, 148.

Peacouk, $8 \%$.

Penguins, 5, 19, 21.

Pee $\left\{\begin{array}{c}0.95 \\ \text {. }\end{array}\right.$

P'ermaszent rewiclenex, detined, 38.

Petrel, Lewedis, ss."

Wiisern's. AB.

Petrochelidon luuifrome, $15 \%$.

Powea, Wood, 62, 186.

Phalarope, 27, 28, 70.

P'heasane, 108.-

Pbilohele minor, 28

Phobe, 18.

Pivi, 114.

lieidan, 116.

Figean, Carrier, 62. Will, :ive.

Pigeona, 20.

I'vicieola enveleator, 148.

Pisutail, 89

Pipile erythmphelialmua, 131.

Pryuetrois jaune, 18\%.

Piranga er thromelna, 165.

Plectrophenax nivalia, 16:.

Plower, Biack bormeated, 99.

Comliten, 59.

Kinhleer, 99.

Piping. 92.

Wilson's, 02

Kisug-neeked, 99.

Sennipalunaterl. 99.

Plovem 41, 19, 98.
Portllymbua padicepa, 84.

Podieipida, 84.

Poocectus granoineus, 141.

Purzane curolina, 94.

Procellariida, 68.

Progno subian 161.

Protective coloration, 42

. colora, 41.

Ptaruigana, 4h.

Pygopocion, 84.

Qunil, 100.

Qusile, 18, 19. 27, 41, 67.

Qunceal uw quisoula, 188.

Rail, Clapper, 94.

King, ve.

Little Black, OL.

Yellow, 24.

Vinginia, 94.

Rnile, $18,20,82,87,98$.

Rallidee, 98.

Rallus orepitans, $\mathscr{H}$.

Ruptores, 114.

Recoynition colors 14

Kedpoll, 146.

Rodstart, 160.

Reodbird, 18.

Regulus calendile, 182

satrapa, 181.

Rliea, 19.

Ricebind, 185.

Rohin, 7, 12, 36, 49, 55, 68, 186 Golden, 181.

Salmnn, B8.

Sandpiper, Semipalmated, os

Apmonbill. 28.

Spottod, 69, 26

Sauropaida. 1.

Sayornin phobe, 124

Scolopacida, 98.

Scotem, 9.

Sealy, B8.

Soiurus aumcapillux 170.

Betophaga ruticilla, 169.

Berual chancters, nocondary, 45. soction, 16. 
Shelldrakes, 89.

Shrike, Loggerhead, 162

Nurthern, 162.

Sialiu siulis, 186.

Signaling colors, $\mathbf{4}$.

Sitta cunadensis, 181.

carolinensis, 180.

Suipe, Wilson's, 97.

Snipus, 28, 36, 41, 43, 49, 67.

Snowbird, slate-colored, 145. White, 147.

Snowflake, 88, 147.

Songs of birls, 62 .

Sora, 44.

Spurrow, Chipping, 142.

Enylish, 141.

Field, 140.

Fox, 144.

Ilouse, 141.

Song, 40, 188 -

Swamp, 139.

'Tree, 146.

Vesper, 141.

White-crowned, 144.

White-throuted, 143

Sparrows, 6, 18, 41, 43, 49, 67, 183.

Spinus triatis, 148.

Spiza americana, 155.

Spizalla pusilla, 140.

monticolu, 146.

socialin, 142.

Spoonbill, Roseate, 33.

Squawk, 92.

Stuke Driver, 98.

Sterna hirundo, 87.

Sturnella magna, 186.

Summer residents, defined, 53.

Sylviida, 181.

Bymiun nebulosum, 111.

Swallow, Bank, 157, 159.

Barn. 157, 158, 159.

Clitt. 157, 158, 159. -

Euve. 159.

Kough-winged, 160.

Tree, 157, 158, 160. -

Swallowm, 6, 27, 55, 156.

Swan, Trumpeter, 90.

Whistling, 90.
Swif, Chimney, 119.

Swifts, 6, 15, 27, 55, 117.

Tachycineta bicolor, 160.

Tuil, the, expression of emotion with 26.

relution between form of, and flight, 25.

sexual characters in, 25.

uses of, 25.

Tunager, Scarlet, 36, 37, 156.

Tanagers, 42, 44, 155.

'Tunagride, 155 .

'Teul, Blue-winged, 89 . Green-winged, 89.

Telencope, 56, 57.

Tern, Common, 87.

Tetraouida, 100.

Thrasher, Brown, 175.

Thrush, Brown, 175. -

Hermit, 185.

Wilson's, 188.

Wood, 12, 184. -

Thrushes, 6, 55, 67, 182.

Thryothorus ludovieiunus, 177.

Titmouse, Tufted, 180.

Towhee, 44, 151.

Transient visitants, defined, 54.

Trochilidæ. 119.

Trochilur colubris, 120.

Troglodytes aédon, 175. hienıalir, 176.

Troglodytida, 178 .

Tubinares, 88.

Turdide, 182.

Turdus aonolarchkre pallaxil, 185.

furcencens, 188.

mustelinus, 184.

Turkey, 27.

Tyrannidæ, 121.

Tyrannus tyrannus, 122

Urinator imber, 85.

Uriuatoride, 85.

Veery, 68, 183.

Virco flavifrons, 165.

gilvus, 165. 
Vireo noveboracesaic, 185.

olivsoues, les.

Virea, Red-oyed, 1 S

Warbling, 16s.

Whilo-ayed, 1ES.

Vollow-chroated, 1CS.

Virenes \&, ss, 1 ea.

Virvonida, 163.

Vulture, Black, 108.

Turkey, 102

Vulturem, \&

W arbler, Black and $W$ Lite, 167.

Black-throated Groen, 168.

Myrele, 168.

Yelluw, 168.

Warblers, 6, 42, 85, 160.

Waxwing, Cedar, 101.

Whip-poor will, \&, 119. -

Widyeon, 89.

Wing, the, an a mosical inatrument ขs.

as wenpon, 24.

effects of use and disuse of, 18, 20

exprestion of ennotion with, 24.

molt of feathers of, 81.

nexual charecter in, $\boldsymbol{x}$.
Wing, tues of, 17.

Wiuter resideaty, defined, os

Woodcock, 23, 34, 48, 93.

Woodhewers, 38, 28, 82.

Wood peoker, Downy, 16, 115. -

Hairy, 118.

Pileared, 14.

Men-headed, 116.

Wood peckers, 5, 6, 8, 14, 16, 16, 25, 20 $64,67,69,114$.

Wren, Carolina, 177.

House, 178.

Long-balled Mansh, 177.

Winter, 176.

Wrens, 65, 178.

Wrybill, 88.

Yellow bird, 148.

Yullow-hammer, 116.

Yellow-throat, Mary land, 171.

Young binds, 70.

Yucker, 116.

Zamelodia ladoviciana, 160.

Zenaidura macroum, 102.

Zonotrichia albicollie, 148.

Zonotrichia leucophrya, 14. 



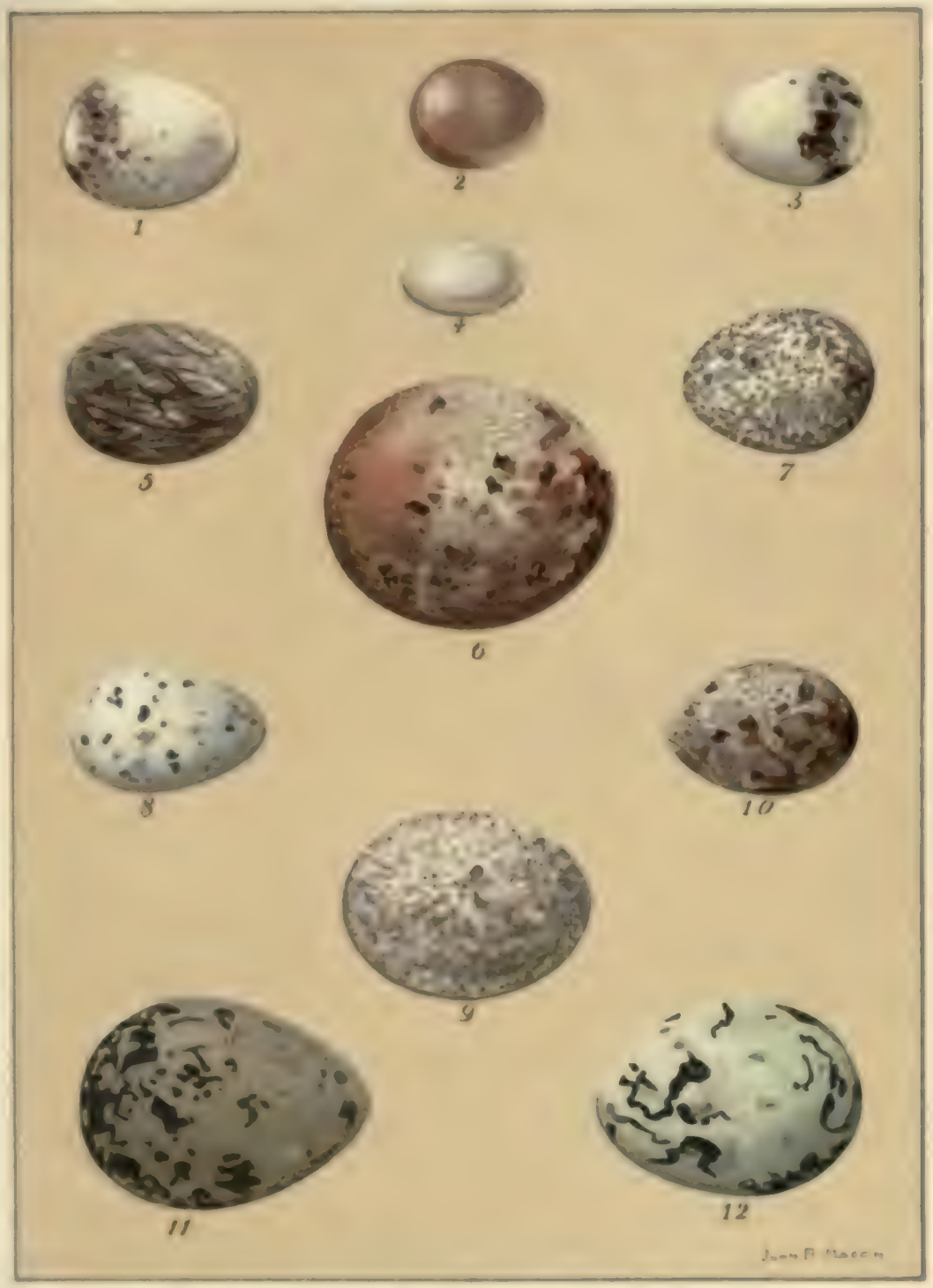

Plate ICI.

TYPES OF BIRD8 EGQ8.

1.-Oven-Bird (orate; spotted and wreathed). 2.-House Wren (ovate: minutaly spreckleal). 3.-Wood Pewree (ovate; blotched and weatherd). 4.- Bumminglird (esllptical; white, unmarkent). 6. -Crestond Flycatcher (elliptical-ovate; streaked). 6.-Sparmow Hawk (spherical: wnathoud, spaitoud and blotcherf). 7.-Cowbird (ovato; evenly epeckled and spotted). 8.-Cevlar Waxwing (olougateovate; eputted). 9.Nighthwok (elliptleal : mottled and marbled). 10.-Bobolink (ovate; appottes! and blotehed). 11. - Semipalmatend Sandpiper (pyriforma ; spotted). 12.-Purple Grackle (ovato ; scrawled). 



\section{APPENDIX.}

FOR TIIE USE OF TEACHERS. 



\section{PREFACE TO TEACHERS' APPENIIX.}

WrtLe the time available for zoülogical studies in our schools is too limited to permit of more than the treatment in outline of most of the classes of animals, the fact is now recognized that birds possess unusual clains to our attention. They are practically the only ones of the higher animals with which we may come in contact daily. Our large mammals have either been exterminated or driven from the vicinity of our homes, while most of the smaller species are nocturnal, and, therefore, rarely seen. Reptiles and batrachians are difficult to observe and are not popular; while fishes, from the nature of their haunts, can be studied only under certain conditims. Birds, however, aro ererywhere: in field and wood and sky, in our orchards and gardens; and some of them are with us at all seasons.

But birls' merits do not consist merely in their abundance. In beauty of plumage, grace of motion, and rocal ability they are withont rirals; in their migration, mating, and nesting habits they not only display unusual intelligence, but exhibit human traits of character that crente within us a feeling of kinship with them, and thus increase our interest in and love for them. Furthermore, as with increasing knowlerge we begin to realize their economic value, wo are more than erer im- 
pressed with the importance of becoming acquainted with them.

Still, it will be obviously impossible for the student to cover the whole field of ornithology, and the question arises, to what phase of the subject he should give special attention.

There are teachers who believe that classification is the principal object of natural history study, and the aim and end of their instruction is to teach the pupil the names of Orders and Families, and the characters on which they are based. So far as birds are concerned, the plan is excellent as a preliminary step, but to my mind it is of infinitely greater importance to be able to recognize a Wood Thrush or a Veery than to define the Lamellirostral Grallatores.

In this bool: structure and classification have, therefore, been subordinated to matter which will be of practical assistance to the student in identifying the birds about his home, and in teaching him to appreciate their economic, æsthetic, and scientific value.

If he lives in the country, this information may be of serrice to lim daily; and this, it seems to me, is a far more profitable kind of ornithology than that which treats only of "Orders," and "Families," and "leading types" which he will probably never see outside of a museum or a zoölogical garden.

Acting on this belief, I hare written of the living, rather than of the dead bird, and no attempt, therefore, has been made to describe the anatomy of birds, but, in preference, the questions of economics, æsthetics, form and habit, color, migration, song, nesting, etc., have been dwelt on with the ob- 
ject of both cultivating and directing the student's powers of observation. In order, however, to give him some ides of the bird's place in Nature, the subjects of relationships and clussification have been touched on briefly. Then follow a series of objec. tire, seasonal lessons which are the main feature of the book. The advantages of studying birds under sensonal groupings are two-fold. First, by eliminating species which are abseut, it greatly simplifies the question of identification. Second, it is more real. If the student can be told that a certain species will doubtless arrive from the south the same day on which he is reading about it, his interest in the subject will be at onco increased; it becomes a matter of contemporary history. Furthermore, by studying the birds with the seasons, we learn in the beginning to properly associate them with certain accompanying natural phenomena, and their comings and goings become significant events in our calendar.

As we become familiar with birds, and learn to recognize them, the question of identity will no longer remain a bar to our better acquaintance, and our interest in them will deepen. We shall begin to inquire into the questions of form and babit, color, migration, song, nesting, etc. ; and as a guide to observations of this character, there are given a series of lessons treating of the philnsophic,or subjective side of bird-study, the wide scope of which will bo readily appreciated.

F. M. C.

axrmas Mugeve of Natural Histort. 



\section{QUESTIONS ON CHAPTER I.}

THE BIRD : ITS PLACE IN NATURE AND RELATION TO MAN.

The Birl's Place in Nature (see Chapter I, pages 1-5).How many species of birls are known? In what class are they placed? Name the classes of higher animals; that is, mammals, fishes, and reptiles. In what respect does the class birds differ from all the other higher classes of animals if What place does the class birds occupy in the scale of life? To what class are they most nearly related ?

Are birds the only higher animals that fly? Are they the only ones that lay eggs? The only ones that incubate? What is the temperature of birds? Of nammals? Of reptiles ? Have any living birds teeth? What is the chief peculiarity of birds? From what kind of ancestors are biris believed to have descended? On what evidence is this belief basod ?

Describe the Archaopteryx. Where was it found i In what gerlogic age did it live? Do birds vary much in structure \& In habit?

Mention some varying habits of birds.

Economic Relations of Birds to Man (seo Chapter I. pages 3-3). - In what ways are birds useful to man? What loss are inserts estimated to inflict on our agricultural intorests annually 1 What birls eatch insects on the wing? In the foliage f On the tree trunks ? What kinds feed on terrestrial insects ? Describe Mr. Forbush's observations

- The teacher should deflne the menning of "Class" : as, fot example, the elnss Mnmmalia. the class Reprilia, cte.

f For example. such extreme representatives of the class Aves as the Ilumeninghiril anil Ostrich, resemble each other in more reaperts thar do, for instance, tbe Bat and the Elephant in the clase Mammalia. 
on the food of the Chickadee. What was found in the stomach of a Yellow-billed Cuckoo? Of a Robin? Are most Hawks and $\mathrm{Owls}$ beneficial birds? What forms the largest part of the food of the Red-shouldered Hawk? What was found in the castings * of the Barn Owl? What State offered a reward for Hawks and Owls? What loss is estimated to have resulted? Why are seed-eating birds of economic value? What birds are useful as scavengers? What was the result of killing birds on the Yucatan Coast ?

AEsthetic Relations of Birds to Man (see Chapter I, pages 10-13).-After learning to know. birds, what æsthetic characters shall we find that they possess? Mention several birds of beautiful plumage. Several of unusually graceful flight. Several musical birds. What buman traits of character are exhibited by birds? What pleasure is to be derived from acquaintance with birds? Is their study restricted to any special season? In what manner will birds appeal to us most strongly ?

Does familiarity with their notes increase the pleasure we receive from bircls? Is this the result of association? In what manner?

* Undigested pellets of hair, feathers, and bones, which are ejected at the mouth by Owls and some other birds. 
OBJECTIVE SEASONAL LESSONS.

Identificution (see Chapter VII). - As a preliminary step to exercises in identification the student should learn to name the parts of a bird's plumage as they are given in Figure 25. The teacher should then select a plato of a land-bird, and placing it at a distance of from twenty to thirty feet from the pupil, have him write a one-minute description of it. This description should include the bird's approximate length,* color of crown, back, tail, wings, throat, breast, and abdomen. It is well to have a blank prepared and ready to fill in with the descriptions of the parts named. To this may be added any particular characters of form (e.g., crests, long tail, etc.) or color (e.g., face or rump marks, eto.).

With this description in hand the student should then turn to the key on page 76 . This is primarily designed to identify birds in Nature, and its major dirisions aro based on the most striking habits of the birls. This, however, would not be appreciable in the birl plate, and the teacher should, therefore, designate in which of the three principal groups the bird belongs. The pupil should then proceed with

- A liohin is en inches, an English or IInuse Sparrow six and one-quarter inches, in length. Mental comparison with either of these familiar birls will enable one to reaclily estimate the length of any of our Passeres. 
the identification of the bird, as explained on page 75 .

Exercises of this nature should be repeated until the student can describe birds quickly and accurately and has thoroughly mastered the use of the key.

If possible, this class-room work should be frequently supplemented by observations in the field. When the country is not available, large parks often prove by no means poor substitutes, and during the migrations they are frequently thronged with birds.

Even when field lessons are out of the question, it is strongly advised that the studies of certain birds be made during the season when they are present. The best plan is to begin in December with the birds which are with us throughout the year, or the Permanent Residents, adding the Winter Visitants in January and February. As the migrants from the south appear, they may form the subjects of the month's lessons, and the course ends naturally in June, when all the summer birds have arrived.

This method associates the birds with their respective seasons, and for the field student is particularly advantageous. He takes up the subject at a time when the comparatively small number of birds present greatly simplifies the question of identification, and before the first migrants arrive in March, should have become familiar with the commoner Permanent Residents and Winter Visitants.

When field work is practicable, each student should keep a record of the birds observed. Notes of this kind, made during the migration, are particularly interesting. They may be entered on a large page ruleri in squares, similar in style to those of a roll-call 
book. The bird's nume is entered at the left side of the page, the date at the top, and the record for the day is placed in the square opposite the bird's name and below the date. It may consist simply of a check or mark indicating that the species was seen, but preferably should give the approximate number of individuals observed; whether the species was hearl singing; whether observed in flocks; and any other information which can be easily and inteili. gibly abbreviated.

A journal should be kept in which to write a more detailed account of the day's experiences. These may also form the subject of compositions, und the class-room work should now include comparison and discussion of observations made in the field. Compositions may also be written on certain species, when the outline of a bird's biography, given on page 73, will furnish suggestions as to the heads under which the subject may be treated.

Later, the philosophic or subjective side of birdstudy may be consiclered, and compositions written on structure and habit, color, migration, nesting, etc.

As a definite guide to seasonal bird-studies in "the midlle Eastern States, the following outline of the bird-life of a year is given. It is based on observations male in the ricinity of New York city, and includes all the land-birds and the commoner waterbirls inhabiting this region. It may be prefaced by a definition of the four groups in which our birds are placed, according to the manner of their occurrence (see page 53), as follows: 


\section{PERMANENT RESIDENTS.}

Permanent Resident species are those which are represented in the same lucality throughout the year. This does not imply that the same indiriduals lire in one locality continuously; few of our birds being Permanent Residents in the strict sense of the word. Doubtless, Ruffed Grouse, Bob-whites, and possibly a few other species, pass their lives in the vicinity of their birth; but most species ranked as Permanent Residents are, in fact, more or less migratory. Thus, in the vicinity of New York city, Chickadees and Bluebirds are found every month of the year; but in October, many migrants of both species may be seen, and it is probable that we then receive our $W$ inter Residents of these species, while the birds that were with us during the summer go farther south to pass the winter.

List of Permanent Residents.

Bob-white.

Ruffed Grouse.

Red-shouldered Hawk.

Red-tailed Hawk.

Broad-winged Ilawk.*

Marsh Hawk.

Sparrow Hawk.

Duck Hzwk。*

Sharp-shinned Hawk.

Conper's Hawk. *

Bald Eagle."

Screech Owl.

Long-eared $\mathrm{Owl}$.*
Short-eared Owl.

Barred Owl.

Great florned Owl.*

Downy Woodprecker.

Hairy Wood pecker.

Red-headed Woodpecker. (Irregular.)

Flicker.

Prairie Ilorned Lark.* American Crow.

Fish Crow.

Blue Jay.

Starling. (Introrluced.)

- Not common. 


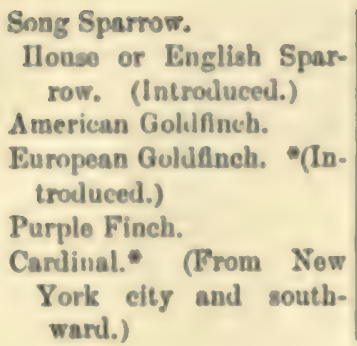

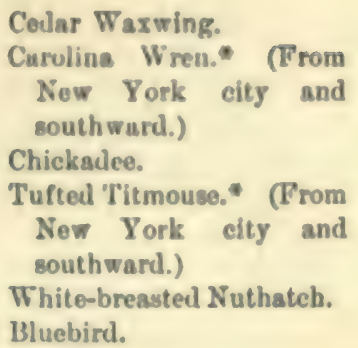

\section{WINTER VISITANTS.}

The term Winter Visitant, like that of Summer Resident, is not used in an exact sense, but is applied to birds that arrive from the north in the fall, pass the winter with us, and return to their more northern homes the following spring. Most of them arrive late in September and depart in A pril.

In addition to these regular Winter Visitants, there sometimes occur irregular Winter Visitants, whose coming cannot be foretold. Absent some winters, they may be abundant others; their presence or absence being apparently governed by the supply of food to the northward. When this fails, they sweep south ward in enormous numbers, becoming common in localities where they are usually rare or unknown. Pine Grosbeaks, Crossbills, and Redpolls are irregular Winter Visitants.

\section{Lise of Wivtea Pistravts}

Herring Gull.

Saw-whet Owl."

Horned lark.
Junoo.

Tree Sparrow.

Pine Siskin. $\uparrow$

- Not conimur.

+leregular. 


\section{Redpoll. $\uparrow$}

Snowflake.

Lapland Longspur.*

American Crossbill. $\uparrow$

White-winged Crossbill.*

Pine Grosbeak. $†$
Northern Shrike.*

Winter Wren.

Brown Creeper.

Red-breasted Nuthatch. $\dagger$

Golden-crowned Kinglet.

TRANSIENT VISITANTS.

This group includes species which pass us each spring in going to their more northern nesting grounds, and which visit us again in the fall in returning to their more southern winter homes.

The earlier Transient Visitants-for example, Wilson's Snipe and the Fox Sparrow-may remain with us a month or six weeks should the season be backward, but the later arrivals-for instance, the Warblers of May, who arrive when the weather is comparatively settled-pass us in a week or ten days.

Most of our Transient Visitants are Ducks, Geese, Snipe, and Plover, who travel far northward beyond the haunt of man to breed in security; and Warblers and Thrushes, who nest in the great spruce and balsam forests of northern New England and Canada.

\section{List of Transignt Visitants.}

Pied-billed Grebe.

Loon.

Blue-winged Teal.

Green-winged Teal.

Pintail.

Canada Goose.
American Coot, *

Wilson's Snipe.

Semipalmuted Sandpiper.

Solitary Sandpiper.

Semipalmated Plover.

Short-eared Owl.

- Not common.

+ Irregular. 
Yellow-bellied Woodpeeker.

Olive-aided Flycatcher.

Yollow bellied Fly. catcher.

Traill's Flycatcher.*

Rusty Blackbird.

Bronzed Grackle.

Nelson Sharp-talled Sparrow.*

Acadian Sharp-tailed Sparrow.*

White-crowned Sparrow."

Lincoln's Sparrow.*

Fox Spartow.

Philudelphin Vireo.

Bluo-healed Vireo.

Nashville Warbler.

Tennesece Warbler.

Cape May Warbler."
Blnck throated Blue Warbler.

Myrte Wurbler.

Magnolin Warbler.

Bay-breasted Warbler.*

Bluck-poll Warbler.

Blackburnian Warbler.

Black-throated Green Warbler.

Yullow Palm Warbler.

Small-billed WaterThrush.

Connecticut Warbler.*

Mourning Warbler."

Wilson's Warbler.

Canalian Warbler.

Titlark.

Ruby-crowned Kinglet.

Gray-cheeked Thrush."

Bicknell's Thrush.*

Swainson's Thrush.

Hermit Thrush.

\section{SUMMER RFSIDENTS.}

The term Sunmer Resident is applied to those species which come to us from the south in the spring, rear their young, and return to the south in the fall. Summer Residents, therefore, are present not only during the summer months, but may arrive in late February or early March, and remain until late November or early December.

As a rule, the first species to come in the spring are the last to leare in the fall, while the later arrivals are among the first departures.

Species that come in March or early April are

- Not common. 
present a month or more before beginning to nest, but those that come in May may be found nestbuilding within a few days after their arrival.

\section{List of Summer Residents.}

Laughing Gull.*

Common Tern.*

Wood Duck.*

Great Blue Heron.*

Little Green Heron.

Black-crowned Night Heron.

American Bittern.*

Least Bittern.

Clapper Rail.

King Ruil.*

Virginia Rail.*

Woodeock.

Spotted Sandpiper.

Killdeer.*

Mourning Dove.

Osprey.

Barn Owl.*

Yellow-billed Cuckoo.

Black-billed C'uckoo.

Belted Kingfisher.

Nighthawk.

Whip-poor-will.

Chimney Swift.

Ruby-throated Hummingbird.

Kingbird.

Crested Flycatcher.

Phobe.

Least Flycatcher.

Acalian Flycutcher.

Wood Pewee.
Baltimore Oriole.

Orchard Oriole.

Red-winged Blackbird.

Purple Grackle.

Bobolink.

Mealowlark.

Cowbird.

Grasshopper Sparrow.

חenslow's Sparrow,*

Swamp Sparrow.

Field Sparrow.

Vesper Sparrow.

Chipping Sparrow.

Rose-breasted Grosbeak.

Towhee.

Indigo Bunting.

Scarlet Tanager.

Barn Swallow.

Rough-winged Swallow.*

Cliff Swallow.

Bank Swallow.

Tree Swallow.

Purple Martin.

Red-eyed Vireo.

Warbling Vireo.

Yellow-throuted Vireo.

White-eyed Vireo.

Black and White War. bler.

Blue-winged Warbler.

Worm-enting Warhler.*

Yellow Warbler.

* Not common. 
Chestnutenitled Warbler.

Pruirio WI nubler.

Redsturt.

Ilooded Warbler.

Oven-birl.

Louisiana Water Thrush. Maryland Yellowthroat.

Kentucky Warbler." Yollow-breasted Chat.
Cathirul.

Brown Thrasher.

Houso Wren.

Short-billed Marsh Wren.

Long billed Marsh Wren.

Veery.

Wood Thrush.

Robin.

Bluebird.

- Not common. 


\section{THE BIRD-LIFE OF A YEAR.}

BASED ON OBSERVATIONS MADE IN THE VICINITY OF NEW YORK CITY.

\section{JANUARY.}

Probably during no other month is there less movement among our birds than in January. All the regular Winter Visitants have come; the Fall Migrants, which may have lingered until December. have gone, and the earliest Spring Migrants will not arrive before the latter part of February or early in March. In fact, January is the only month in the year in which, as a rule, some birds do not arrive or depart. This rule, however, may be broken by such irregular birds as the Pine Grosbeak and Redpoll, and, south of the latitude of New York city, by the Snowflake and Crossbill, birds which are wholly absent some winters and abundant others.

The only birds usually to be found in January, therefore, are the Permanent Residents and regular Winter Visitants. Singing, mating, nesting, molting, migrating-events which, in their season, play so important a part in a bird's life-do not concern the birds of January. With them food is the one important question, and their movements at this season are governed solely by the food supply. Snow may fall and winds may blow, but as long as the birds find sufficient to eat, they give small heed 
to the weather. Where seed-bearing weeds are accessible, there we may look for Juncos and Treo Sparrows; a cedar-treo filled with berries often tempts Robins, Bluebirds, and Waxwings to winter near it. I recall a sheltered pile of buckwheat chaff at Englewood, N. J., which furnished food for a small flock of Mourning Doves all one winter. In Central Park, New York city, a Mockingbird, who had evidently escaped from a cage, fed upon the berries of a privet tree, and survived in apparent comfort the most severe winter weather. Food, therefore, rather than temperature, is the all im. portant factor in a bird's life at this season.

\section{BIRDS OF TIE MONTH.}

Peruanest Residests (see page o).

Wuxter Vhastakts (seo page 7).

\section{Febreary.}

The conditions prevailing in the bird world during January will be practically unchanged until the latter part of February. Then, should there be a period of milder weather, wo may expect to hear the Song Sparrow and Bluebird inaugurate the season of song. An unusually warm day, earlier in the month, may have tempted either or both of these birls to prematurely welcome spring, but as a rule we do not hear them until late in February, and then only under faromble conditions.

The sone of these birds bids us keep watch for the earliest migrants, the Robin, Purple Grackle, and 
Red-winged Blackbird, birds which pass the winter such a short distance south of us that they appear at the first sign of returning spring.

Further confidence in the growth of the new year is shown by the Great Horned Owl, one of our less common species, who begins nesting late in February or early in March.

But in spite of these movements among the birds, February is, generally speaking, a winter month, and it is only in exceptional years that we shall find much change in our avifauna.

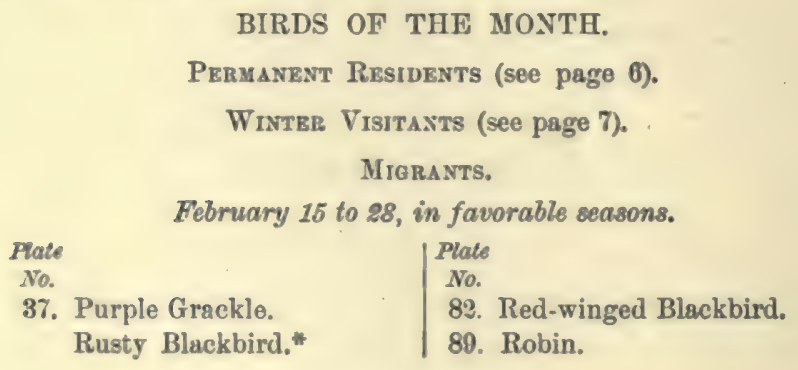

Plate

No.

37. Purple Grackle. Rusty Blackbird.* $\mid \begin{aligned} & \text { Plate } \\ & \text { No. } \\ & \text { 82. Red-winged Blackbird. } \\ & \text { 89. Robin. }\end{aligned}$

Brads Nestive.

Great Horned Owl-February 20-28.

\section{MAROH.}

While March is sure to witness a general north. ward movement among the birds, the date of their arrival is as uncertain as the weather of the month itself. Continued severe weather prevents their advance, which a higher temperature as surely occasions. It is well, therefore, to watch closely the weather predictions, knowing that birds will quickly

* Transient Visitant passing further north. 
follow in the wake of a warm wave. When the ice leaves our bays, ponds, and rivers, Ducks and Geese will appear. Even before this event, the Grackles, Red-winged Blackbirds, and Robins will come in flocks and in song, and singing will become general with the Song Sparrows and Bluebirds, whose numbers will be greatly increased. When successive thaws have rendered the earth soft enough for the Woolcock's probe, we may expect to find him in favorable lucalities, searching for his fare of earthworms. With the advent of insects, we may look for their enemy, the Phobe, and when the frogs begin peeping in the ponds and marshes, we shall know that the spring migration is well under way, and that Meadowlarks, Cowbirds, and other March Migrants may be found for the seeking.

To the lover of bird music the event of the month will be the first Fox Sparrow song; heard at this seasn it is a thrilling performance.

The weather which hastens the arrival of birds from the south, also prompts certain of our Winter Visitants to begin their northward journey, and after March we do not often see Redpolls, Snow. Alakes, and Northern Shrikes.

\section{BIRDS OF THE MONTH.}

\section{Penanest Residests (see page 6).}

Wisten Viatakts (seo pago 7 ).

The following will leave for the north:

Fate
Na. Rnmed Lark.
84. Rnmed.
50. Redpoll.
50. Snownake.




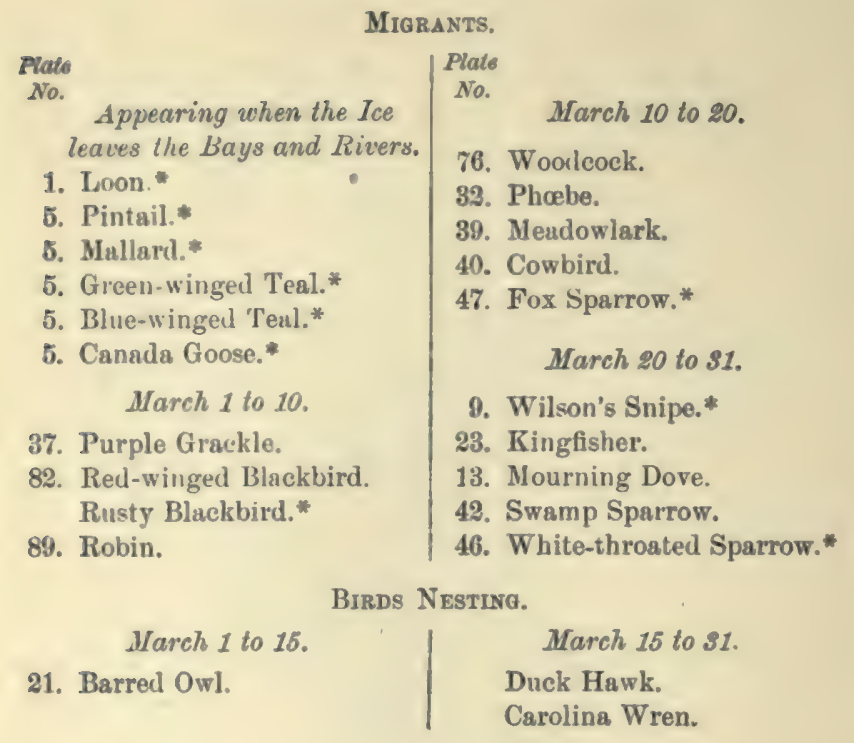

APRIL.

In early April, the developments in the vegetable world, which the most casual observer cannot fail to see, are accompanied by corresponding, but less noticed, activities in the world of birds. The appearance of the skunk cabbage, the blossoming of the pussywillow and early wild flowers soon become common knowledge; but the arrival of the Vesper, Field, and Chipping Sparrows; of Tree Swallows, Myrtle Warblers, and Hermit Thrushes, is known to comparatively few. Still, to the birdlover, the return of these feathered friends is of even greater interest than the blooming of trees and plants.

- Transient Visitant passing further north. 
The migmtory movement rapidly grows in strength, and, during the latter part of the month, one smay expect to see new comers almost daily.

It will be noted that the earlier migrants of the month are all seerl-eaters, who return just in time to help the remaining Winter Visitants harvest what is left of the preceling year's crop of seeds. Later, certain insectirorous birls which catch their prey on the wing are found; for example, the Swallows, Swift, and Nighthawk.

\section{BIRDS OF THE MONTH. \\ Pemmanent Residents (see page 6). \\ Remainiso Wister Visitasts (see page ク).}

The following will leave for the north:
Hole
Na.
48. Junco.
19. Tree Sparrow.
Winter Wren.

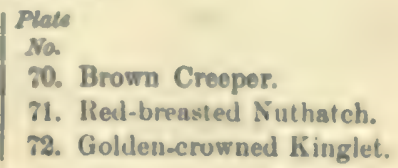

20. Brown Creeper.

71. Red-breasted Nuthatch.

72. Golden-cruwned Kinglet.

\section{Mrorasts.}

Aprib 2 to 10.

2. Pied-billed Grebe.

6. Great Blue Ileron."

6. Bluck-crowned Sight lleron.

18. Osprey.

4. Vesper Sparrow. Saranne Sparrow.

48. Ficld Sparrow.

4.. Chipping Sparrow.

1. Troe Swallow.

61. Mrrile Wurliler."

- American I'igric.
75. Hermit Thrush.

$$
\text { April } 10 \text { to } 20 .
$$

7. American Bittern.

6. Oreen Heron.

8. Clapper Rail.

Yellow-bellied Wood. pecker.

1. Barn Swallow.

Yellow Puln Warbler.

Pine Warbler.

Lourisiana Water Thrush.*

72. Ruby-crownel Kinglet."

- Transient Vivitant passing further north. 


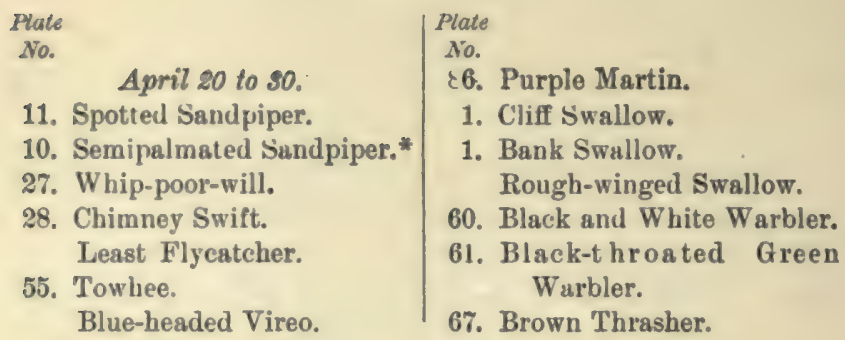

\section{Birds Nesting.}

(In addition to the species which began to nest in March, all of which will have eggs or young in April, the following may be found nesting) :

Plate

No.

76. Woodcock.

$$
\text { April } 1 \text { to } 15 .
$$

14. Red-shouldered Hawk.

20. Screech Owl.

Red-tailed Hawk.

80. Americun Crow.

Long-eared Uwl.

90. Bluebird.
Plate

No.

April 15 to 30.

71. White-breasted Nut. hatch.

89. Robin.

18. Mourning Dore.

37, 91. Purple Grackle.

32. Phobe.

41. Song Sparrow.

\section{MaY.}

As the season advances, marked changes in temperature are less likely to occur, and the migration becomes more regular and continuous. In February and March there may be two weeks or more variation in the times of arrival of the same species in different years ; in May we can expect to find a given species within a day or two of a certain date. Nevertheless, we shall find the force of the migratory current still closely dependent on meteorologic

* Transient Visitant passing further north. 
conditions, and under the encouragement of a high temperature we may be visited by bird "waves" which flood the wooks with migrants. Birls are then, doubcless, more abundant than at any other period of the year. As many as ten species may be noted as arriving on the same day, while the num. ber of individuals observed may almost exceed calculation. At this season it is not unusual to observe from sixty to eighty species of birds during a fow hours' outing, and Mr. W. L. Dawson recorls that, with Prof. Lynds Jones of Oberlin College, he recorled twelvo species of water birds and ninety species of land birds in one day of field work in Lomin County, Ohio.

After the fifteenth of the month, birds begin to decrease in number, the Transient Visitants passing further north, and by June 5 our bird-life is com. posed of Permanent Residents and Summer Residents.

It will be noticed that with fer exceptions the birds arriving in May are insectivorous ; particularly those insect-eating birds which obtain their food from the vegetation. Thus, no sooner are the unfolding leaves and opening blossoms exposed to the attack of insects than the Warblers and Vireos appear to protect them, and the abundance of these small birls is the distinctive feature of the bird-life of the month.

Their diminutive size, activity, and the persistence with which they remain in the tree-tops render their identification in life by no means an easy matter. and more than any of the other land birls they test the patience of the field student. 
May is preëminently the month of courtship, which finds expression chiefly in song. Many species begin to nèst in May, but the nesting season reaches its height the following month.

\section{BIRDS OF TIE NONTH.}

\section{Permanent Residents (see page 6).}

\section{Migrants.}

Prate

No.

May 1 to 10.

10. Common 'Tern.

Solitary Sandpiper.*

10. Semipalmuted Plover."

22. Yellow.billed Cuckoo. Black-billed Cuckoo.

27, 91. Nighthawk.

29, 91. Ruby-throated Hummingbirl.

31, 91. Crested Flycatcher.

30. Kingbird.

35. Baltimore Oriole.

36. Orchard Oriole.

38, 91. Bobolink.

Grasshopper Sparrow.

83. Indigo Bunting.

54. Rose-breasted Grosbeak.

85. Scarlet Tanager.

50, 91. Red-eyed Vireo.

Warbling Vireo.

59. Yellow-throated Vireo.

White-eyed Vireo.

Nashrille Warbler.*

Blue-winged Warbler.

Parula Warbler.

Black-throated Blue Warbler."

\section{Plate}

No.

Magnolia Warbler.*

Chestnut-sided Warbler.

Pruirie Warbler.

Small-billed Water Thrush.*

Hooded Warbler.

87. Yellow Warbler.

64, 98. Maryland Yellowthroat.

65. Yellow-breasted Chat.

63, 91, 97. Oven-bird.

62. Redstart.

68, 91. House Wren.

88, 99. Catbird.

74, 100. Wood Thrush

78. Veery.

\section{May 10 to 20.}

33. Wood Pewee.

Acadian Flycatcher.

Yellow-bellied Flycatcher.

White-crowned Sparrow, *

Golden-winged Warbler."

Tennessee Warbler,*

Worm-eating Warbler.

Capo Mry Warbler.*

Blackburnian Warbler.

Bay-breasted Warbler。*

- Transient Visitant passing further north. 
Fale

Na.

Black-poll Warbler.*

Wilson's Warbler."

Canadian Warbler.

09. Long-billed Marsh Wren.

Short-billed Narsh Wren.
Plase

Sa.

Olive-backed Thrush.

Gray cheeked Thrugh."

Traill's Flycatcher."

Mourning Warbler."

Bicknell's 'Thrush.

\section{Birdes Nestiso.}

(In aldition to the species which hegan to nest in $\mathrm{May}$, all of which will have eggs or young in June, the following may be found nesting:)

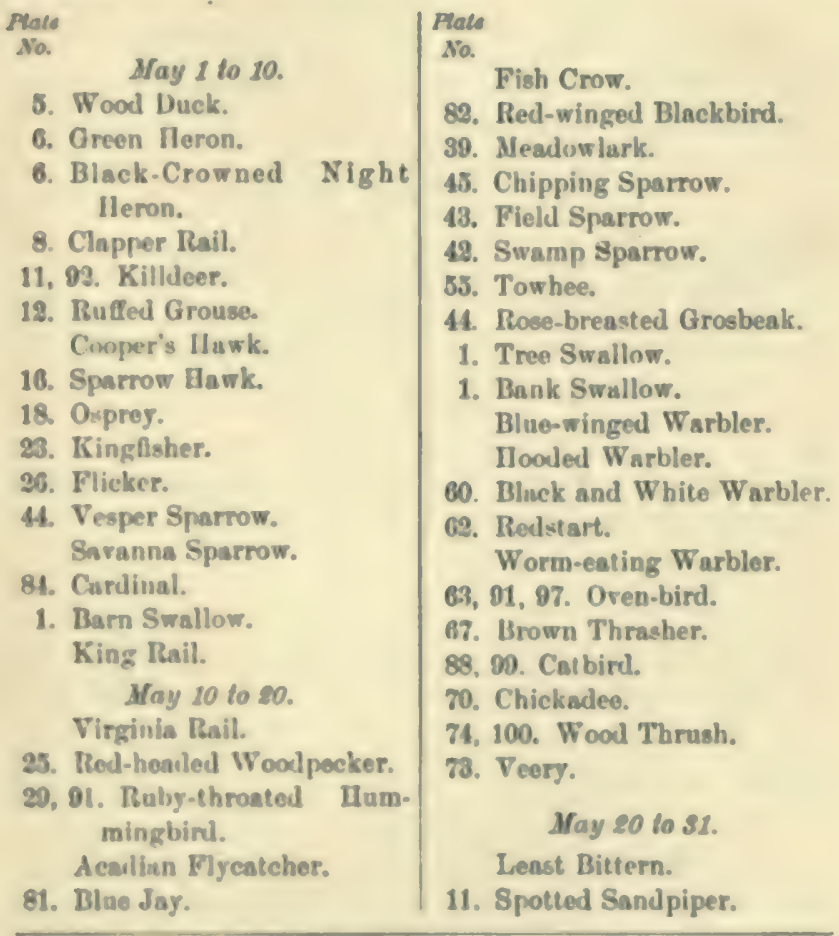

- Transient Visitant passiug further north. 
Flate

No.

77. Bob-white.

17. Sharp-shinned Hawk.

15, 93. Marsh Hawk.

22. Yellow-billed Cuckoo. Black-billed Cuckoo.

24. Downy Woodpecker. Hairy Woodpecker.

28. Chinney Swift.

30. Kingbird.

Least Flycatcher.

38, 91. Bobolink.

36. Orchard Uriole.

35. Baltimore Oriole.

Grusshopper Sparrow.

89. Iudigo Bunting.
Plate

No.

53. Purple Finch. White-eyed Vireo.

59, 96. Red-eyed Vireo.

Warbling Vireo.

59. Yellow-throated Vireo.

86. Purple Martin. Rough-winged Swallow.

1. Cliff Swallow.

Chestnut-sided Warbler.

Prairie Warbler.

65. Yellow-breasted Chat.

64, 98. Maryland $\mathrm{Yellow}$ throat.

69. Long-billed Marsh Wren.

\section{JUNE.}

After June 5 we may be reasonably sure that every bird seen has, or has had, a nest in our vicinity. Several of the birds which began nesting in Aprilfor instance, the Phœebe, Song Sparrow, Robin, and Bluebird-will rear second broods in June, while the young of other April nesting birds, such as the Red-shouldered Hawk, Screech Owl, and Crow, may not leave the nest until June. All the birds that began nesting in May will still be occupied with household affairs in June; and when we add to these the late-breeding species which wait for June before settling their domestic arrangements, it will be seen that among birds June is the home month of the year.

Nest-building, egg-laying, incubating, and the care of the young now make constant and exceptional demands on birds, who, in response, exhibit 
traits which at other times of the year they give no evidence of possessing. Singing now reaches its highest development, and certain call-notes are heard only at this season. The numberless actions incident to courtship; the intelligence displayed in nest-building; the choice of special food for the young; the devotion which prompts the parents to recklessly expose themselves in the protection of their offspring-all these manifestations of the bird-mind may be observed in June.

A feature of the bird-life of the month is the formation, usually in young second-growth woods, of roosts which are nightly frequented by the now fully grown young of such carly-breeding birds as the Purple Grackle and Robin. When a second brood is raised, as with the Rubin, the young of the first brood may be accompanied to the roost by the male parent, but in the one-brooded Grackle the roost is used by both adults and young.

BIRDS OF TIE MONTH.

Permanest Residents (see page 6).

Sumuea Residents (see pago 10).

Birds Nestise.

(In aldition to the species which began to nest in May, all of which will have eggs or young in June, the following may be found nesting:)

Plate

Na

June I to 10.

Laughing Gull.

2\%, 91. Nighthawk.

27. Whip.poor-will.

81. 01. Crested Flycatcher.

83, 91. Wood Peweo.
Fate

$\mathrm{Na}$

85. Scarlet Tanager.

June 101020.

10. Common Tern.

57, 91. Celar Waxwing.

52. American Goldfinch. 


\section{JULY.}

The full development of the bird year is attained in June, and as early as the first week in July, when, among some migratory birds, there are evidences of preparation for the journey southward, the season begins to wane. The young of certain species which rear but one brood have now left the nest, and, accompanied by their parents, wander about the country. In localities which we had thoroughly explored in June, we may therefore find species not met with before. In some cases, these families join others of their kind, forming small flocks, the nucleus of the great gatherings seen later. Examples are Grackles, Red-winged Blackbirds, and Tree Swallows. The latter rapidly increase in number, and by July 10 we may see them, late each afternoon, flying to their roosts in the marshes.

During the first week in the month we shall also find that certain birds have concluded their season of song.

Bobolinks and Red-winged Blackbirds are rarely heard after the tenth of the month; their young are reared, the cares of nesting-time have passed, and, with other one-brooded birds, they begin to renew their worn breeding plumages by molting. After the fifteenth we miss the voices of the Veery, Orchard and Baltimore Orioles, Chat, Brown Thrasher, and others. But in place of the songs of these more prominent members of the bird choir, we notice the calls of certain young birds who, long after they have left the nest, are still dependent on their parants; thus the squawkings of young Crows and trem- 
ulous cries of immature Baltimore Orioles are characteristic of the season.

\section{BIRDS OF THE MONTH.}

Pramaneart Residents (seo page 0).

Sumurk Residexts (see page 10).

\section{A Eavst.}

With the majority of our nesting birds, family cares are ended in August, and at this season they completely renew their worn plumages by molting. As every keeper of cage-birls well knows, this is a trying period in a bird's !ife. Wild birds molt more quickly than caged ones, and it is possible that the physical strain to which the growth of new feathers sukjects them may be more severe. However this may be, birds when molting are less in evidence than at any other time. What becomes of many of our birds in August, it is difficult to say. Baltimore Orioles, for example, are rarely seen from August 1 to 20 , but after the latter date they reappear clad in new plumage and are then in nearly full song. So apparently complete is the disappearance of birds in August that before the fall migration daily brings new arrivals from the north, one may spend hours in the woods, and hear only the Red-eyed Vireo and Wood Perree, August's own songsters. Late in the month, migrants from the north will be found trarelling through the woods in suall com. panies, but the characteristic bird-life of August will be found in the marshes. There the Swallows is 
come in increasing numbers to their roosts in the reeds, while Red-winged Blackbirds, and Bobolinks under the alias of Reedbird, are abundant where the wild rice grows.

August is practically the last month of the nesting season as well as of the song season. The latebreeding Goldfinch and Waxwing are occupied with family matters in August, and Song Sparrows sometimes rear a third brood in this month; but with these. exceptions, birds are rarely found nesting in August.

\section{BIRDS OF THE MONTH.}

\section{Permaneat Residents (see page 6.)}

Summer Residents (see page 10).

Migrants arriving from the North.

Plate

No.

7. Sora。*

August 1 to 15.

10. Semipalmated Sandpiper.*

10. Semipalmated Plover.* Yellow-bellied Flycatcher." Golden-winged Warbler.* Chestnut-sided Warbler.* Canadian Warbler.* Small-billed Water Thrush.*

August 15 to $\$ 1$. Olive-sided Flycatcher.*
Plate

No.

Tennessee Warbler.*

Nashville Warbler.*

Parula Warbler.*

Cape May Warbler.*

61. Black-throated Green War. bler.* *

Black-throated Blue War bler.*

Magnolia Warbler.*

Blackburnian Warbler.*

Wilson's Warbler.*

71. Red-breasted Nut. hatch. $\uparrow$

* Transient Visitant passing further south.

t Irregular Winter Visitunt. 


\section{SerteMmer.}

The student whose patience has been sorely tried by the conparative scarcity of birds in August, will find that in September his observations in the field will be attended by far more interesting results. The first marked fall in the temperature is sure to be followed by a flight of migrants which, like the "waves" of May, will flood the woods with birds. The larger number will be Warblers; indeed, September, with May, is characterized by the abundance of these small birds.

Birds of the year will outnumber the adults, and, in most cases, their plumage will be quite unlike that worn by their parents in May, while, in many instances, even the adults themselves will appear in a changed costume. Often this new dress will resemble that of the immature bird, a fact which accounts for the apparent absence of old birds in the fall migration.

As a rule, fall plumages are less striking than those of spring, and when, in addlition, it is remembered that birds are not in song, and that the foliage is much denser, the greater difficulty of field identification at this season will be appreciated.

In September more migrating birds are killed by striking lighthouses than in any other month of the year. This is doubtless owing to the fact that stormy or foggy weather is more apt to prevail in September than during any other period of active migration; that the majority of the migrants are young and inexperienced, and that in September migrants are more numerous than in any other month. 
About September 25, our more common Winter Visitants arrive from the north, and after that date birds rapidly decrease in number.

Few songs are heard during the month; the characteristic bird-notes being the sharp keè-yer of the Flicker, and the calls of Blue Jays gathering their autumn toll from the chestnut trees.

\section{BIRDS OF THE MONTH.}

\section{Permanent Residents (see page 6).}

Summer Residents (see page 10).

The following will depart for the south:

Plate

No.

September 1 to 10.

Acadian Flycatcher.

36. Orchard Oriole.

Rough-winged Swallow.

Worm-eating Warbler.

Blue-winged Warbler.

\section{September 10 to 20.}

35. Baltimore Oriole.

86. Purple Martin.

87. Yellow Warbler.

65. Yellow-breasted Chat.
Plate

No.

September 20 to 30.

10. Common Tern.

6. Little Green Heron.

29. Hummingbird.

30. Kingbird.

31. Crested Flycatcher.

33. Woud Pewee.

54. Rose-breusted Grosbeak.

59. Yellow-throated Vireo.

Warbling Vireo.

Hooded Warbler.

Louisisna Water Thrush.

78. Veery.

Migrants arriving from the Norte.

September 1 to 10.

Lincoln's Sparrow.*

Black-poll Warbler.*

Connecticut Warbler.*

September 10 to 20.

8. Wilson's Snipe."
Blue-headed Vireo.*

Olive-backed Thrush.*

Bicknell's Thrush.*

September 20 to 50.

4. Herring Gull.t

5. Green-winged Teal.*

* Transient Visitant passing further south. + Winter Visitant. 
Fele

No.

5. Blue-winged Teal.*

8. American Coot. *

48. Junero. $\uparrow$

46. Whute-throated Sparrow. White-erowned Sparrow."

61. Myrtle Wurbler."
Hate
No.
Yellow Paim Warbler.*
70. Brown Creeper. $\uparrow$
72. Golden-crowued Kinglet. $\uparrow$
72. Ruby-crowned kinglet."
Winter W ren. $\downarrow$
Gray-cheeked Thrush."

\section{Octorer.}

Early October generally brings the first killing frost, depriving insectivorous birds of a large part of their food, and of necessity forcing them to journey southward. Flycatchers, Warblers, Vireos, and Swallows now take their departure, and after the fifteenth of the month few insect-eating birds remain, except those which, like Woodpeckers, feed on insects' larræo or eggs.

This is the season of Sparrows. In countless numbers they throng old stubble, potato, or corn fields, doing untold good by destroying the seeds of noxious weeds. Song, Field, Chipping, and Vesper Sparrows may be found in flocks, all harvesting the year's crop of seeds, and with them will be the lately arrived Juncos, Tree and Fox Sparrows. When disturbed, they seek shelter in the nearest hedgerow, and their mingled notes produce a twittering chorus, in which it is difficult to distinguish the voices of individual birds.

This, however, will not be the only bird music of the month. Certain species now have a brief

- Transient Visitant passing further south.

\& Winter Visitant. 
second song period, and on the brighter days of the month we may hear Song, White-throated, and Fox Sparrows, Phœbes, and Ruby-crowned Kinglets in song.

The diurnal migration of Crows and Ilawks is a feature of the bird-life of the month. In scattered companies they string across the sky, en route to more productive feeding grounds.

\section{BIRDS OF THE MONTH.}

\section{Prrmanent Residents (see page 6).}

Remaining Summer Residents (see page 10).

The following will depart for the south :

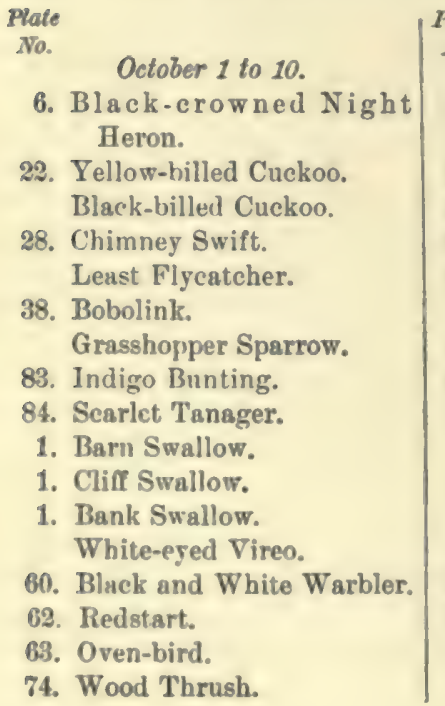

Plate

No.

October 10 to 20.

11. Spotted Sandpiper.

27. Whip-poor-will.

27. Nighthawk.

59. Red-eved Vireo.

64. Maryland Yellowthroat.

69. Long-billed Marsh Wren. Short-billed Marsh Wren

68. Mouse Wren.

67. Brown Thrasher.

88. Catbird.

\section{October 20 to $s 1$.}

2. Pied-billed Grebe.

32. Phœbe.

55. Towhee.

1. Tree Swallow. 


\section{Migmasts ameviso mox tab Nonth.}

Plate

$\mathrm{Na}$

October 1 to 10.

\section{Lnon.*}

б. Pintuil.*

5. Mullard.

5. Canada Goore.* Brunzeil Grackle.* Rusty Bluckbirl.* American Pipit.

75. Hermit Thusush.
Pats

No.

October 10 to 20.

47. Fox 8parrow."

Oetober 20 to $\mathbf{s 1 .}$

84. Horned Lark. $\nmid$ Pine Finch. $\uparrow$

49. Tree Sparrow. $\nmid$

5i). Snowfinke. $\uparrow$

50. Redpoll. $\uparrow$

58. Northera Shrike.

\section{NoveMrBer.}

It is an interesting fact that the last migrants to leave in the fall are the first to arrive in the spring.

The bird-life of November, when the fall migration is practically concluded, closely resembles, therefore, that of March, when the spring migration is inaugurated.

The reason for this similarity is to be fonnd in the fact that both months furnish birds with essen. tially the same kind of food. Thus the Loon, Grebes, Ducks, Geese, and Kingfisher remain until Norem. ber or early December, when the forming of ice deprives them of food and forces them to seek open water. Wondcock and Snipe linger until they can no longer probe the frost-hardened earth; but the thaws of March will bring all these birds back to us by restoring their food.

- Transient Visitant passing further south.

+ Winter Visitant. 
Certain Sparrows stay with us until the weeds bearing the seeds on which they feed are covered by snow, when they are compelled to retreat further southward, returning, however, as soon as March suns lay bare the earth.

Few birds' songs are heard in November. In some sheltered, sun-warmed hollow, Song and Whitethroated Sparrows may continue in voice, but the characteristic bird-note of the month is the sweet, minor "scatter-call" of Bob-whites, who, after their sudden flight from the sportsman, endeavor to find one another by a questioning, whistled whère-areyou? whère-are-you?

\section{BIRDS OF THE MONTH.}

Permanent Residents (see page 6).

Remaining Summer Residents (see page 10).

The following leave for the south, concluding the fall migration :

Flate
So.
5. Wood Duck.
6. Great Blue Heron.
7. American Bittern.
76. Woodcock.
13. Mourning Dove.
23. Belted Kingfisher.
88. Red-winged Blackbird.
Plate
87. Purple Grackle.
40. Cowbird.
44. Vesper Sparrow.
43. Field Sparrow.
45. Chipping Sparrow.
42. Swamp Sparrow.

\section{December.}

The character of the bird-life of December depends largely upon the mildness or severity of the season. Should the ponds and streams remain open, the 
ground be unfrozen, and little or no snow fall, uany of the migrant species of November will linger int, December. They rarely ure found, however, after the middle of the month, when our bird-life is reduced to its simplest terms, being com. posed only of the ever-present Permanent Residents and the Winter Visitants.

The comparative scarcity of food now forces birds to forage actively for provisions, and when a supply is found they are apt to remain until it is exhausted. Their wanderings lead them over large areas, and our dooryards and orchards may often be visited by species which, when food is more abundant, do not leare their woodland haunts. An excellent way in which to attract them is to provide them with suitable food. Crumbs and seeds scattered in some place where they will not be covered by snow, or blown away, will bring Juncos, Tree Sparrows, and Purple Finches; an old seed-filled sunflower head may prove a feast for Goldfinches, while bits of ment, suet, or ham bone hung from trees will be eagerly welcomed by Chickadees, Nuthatches, and Downy Woodpeckers. 


\section{LISTS OF BIRDS}

OBSERVED AT WASHINGTON, D. C.; PHILADELPHIA, PA.; PORTLAND, CONN.; CAMBRIDGE, MASS.; ST. LOUIS, MO.; OBERLIN, O., AND MILWAUKEE, WIS.

TнE dates given in the preceding review of the bird-life of the year will not, of course, hold good for localities far removed from the vicinity of New York city. Notes from various localities on the birds included in "Bird-Life" are, therefore, appended as a guide to students living in other parts of the eastern United States. These notes have been generously contributed by ornithologists whose long-continued observations make them the authorities on the birds of the sections from which they write.*

NOTES FROM WASHINGTON, D. C., ON BIRDS INCLUDED IN "BIRD-LIFE."

Br Dr. C. W. Richmond.

Pied-billed Grebe.-Common Winter Visitant, August 25 to April or May.

Loon.-Common Winter Visitant, September to A pril 25.

Herring Gull.-Common Winter Visitant, October to March.

Common Tern.-Irregular Transient Visitant, sometimes common.

Wood Duck.-Uncommon Permanent Resident.

* The dates given in the following lists of birds are the average dates on which the species occur. 
Pintail. - Winter Visitant, October to April.

Mallard.-Conmon Winter Visitant.

Green-winged Teul. - Cummon Winter Visitant, September to April.

Blue-winged Teal.-Common Winter Visitant, September to April.

Canada Goose.-Winter Visitant, and rather common Transient Visitant, October to A pril.

Great Blue Heron,-Rather common, absent only in midwinter.

Little Green Heron.-Very common Summer Resident, April 15 to September.

American Bittern.-Not uncommon Summer Resident ; occasional in winter.

Sora_-Common Transient Visitant, March; July to November.

Clapper Rail.-Accidental; one record.

American Coot.-Common Trunsient Visitant, March to May ; September to October 15.

Woodcock.-Ruther common from February to November: a few winter.

Spotted Sandpiper.-Common Transient Visitant ; not com. mon Summer Resident, A pril 5 to September 30.

Wilson's Snipe.-Common Transient Visitant, March to May; September to November; occasional in winter.

Semipalmated Sandpiper.-Rare Transient Visitant, May : August to October.

Killdeer.-Permanent Resident, most abundant in migrmtions.

Semipalmated Plover.-Casual, three specimens, May ; August.

Bob-white.-Common Permanent Resident.

Ruffed Grouse.-Not common Permanent Resident.

Mourning Dove.-Permanent Resident, common except in winter.

Turkey Vulture.-Abundant Permanent Resident.

Red-shouldered Hawk. - Common Permanent Resident.

Red-tailed Hawk.-Common Winter Visitant; rare Sum. mer Resident. 
Marsh Hawk.-Common Winter Visitant, July to April. Sparrow Hawk.-Common Winter Visitant, rare Summer Resident.

Sharp shinned Hawk.-Common Permanent Resident.

Cooper's Hawk.-Common Permanent Resident.

Bald Eagle.-Not common Permanent Resident.

Osprey.-Uncommon Summer Resident, March 25 to October.

Short-eared Owl.-Common Winter Visitant.

Long-eared Owl.-Common Permanent Resident.

Screech Owl.-Common Permanent Resident.

Barred Owl.-Not common Permanent Resident.

Yellow-billed Cuckoo.-Common Summer Resident, May

2 to October 15.

Black-billed Cuckoo.-Rather rare Summer Resident, May

2 to October 15.

Kingfisher.-Common Permanent Resident.

Downy Woodpecker. -Common Permanent Resident.

Hairy Woodpecker.-Rare Permanent Resident.

Red-headed Woodpecker.-Rather common Summer Resident; rare Winter Visitant.

Flicker.-Common Summer Resident; rare Winter Visitant.

Nighthawk.-Not common Summer Resident; abundant Transient Visitant, April 20 to October.

Whip-poor-will.-Common Summer Resident, April 15 to October.

Swift.-Abundant Summer Resident, April 15 to October 10.

Ruby-throated Hummingbird.-Common Summer Resident, April 28 to September.

Kingbird.-Common Summer Resident, April 20 to September.

Crested Flycatcher-Very common Summer Resident, April 25 to September.

Phøbe.-Common Summer Resident, March 5 to October.

Occasionally winters.

Least Flycatcher.-Common Transient Visitant, April 25 to May 25; August 28 to September 25. 
Wood Pewce.-Common Summer Resident, April es w October 15.

Horned Lark.-Common Winter Visitaut, November to March or April.

Crow. - Abundaust Permanent Resident.

Bluo Jay.-Rather rare Permanent Resident; common Transient Visitant, April 28 to May 15; September 15 to October 15.

Baltimore Oriole.-Rather common Summer Resident, A pril $2 S$ to September.

Orchard Oriole.-Common Summer Resident, April 28 to September.

Red-winged Blackbird.-Common Permanent Resident, abundant in migrations.

Purple Grackle.-Common Transient Visitant and Summer Resident, February 20 ; a few winter.

Bobolink.-Transient Visitant, common in spring, abuudant in fall, May 1 to 27; August 5 to October 1.

Meadowlark.-Common Permanent Resident; less common in winter.

Cowbird.-Rather raro Permanent Resident; common Transient Visitant.

Song Sparrow.-Common Permanent Resident; abundant Transient Visitant, March and October.

Swamp Sparrow.-Very common Transient Visitant, April to May 15; September 25 to Octuber 30 ; a few winter.

Field Sparrow.-Very common Permanent Resident.

Vesper Sparrow.-Permanent Resident, very conmon in migrations; less so in summer and wivter.

Chipping Sparrow.-Common Summer Resident; abundant Transient Visitant, March 15 to November 1; oceasionally winters.

White-turoated Sparrow. - Very common Winter Visitant, September 28 to May 20.

White-crowned Sparrow.-Irregularly common Winter Visitant and Transient Visitant, April 15 to May 15: October 15 to November 30.

Fox Sparrow. - Very abundant Transient Visitant. February 5 to April 5 ; October 25 to November; a fow winter. 
Junco. -Abundant Winter Visitant, October 5 to April 25. Tree Sparrow.-Abundant Winter Visitant, November 1 to April 5.

Redpoll.- Very rare and irregular Winter Visitant. Snowflake.-Casual in winter; one instance.

American Crossbill.-Irregular Winter Visitant, sometimes abundant.

Pine Grosbeak.-Casual in winter.

Goldfinch.-Common Permanent Visitant.

Purple Finch.-Common Winter Visitant, September 15 to May 15; largely a migrant.

Rose-breasted Grosbeak.-Rather common Transient Visitant. May 1 to 20; August 25 to October 1.

Towhee.-Common Sumner Resident; very common

Transient Visitant. April 15 to May 15; September to October 15 ; a few winter.

Indigo Bunting.-Common Summer Resident, April 28 to October 15.

Cardinal.-Common Permanent Resident; less common than formerly.

Scarlet Tanager.-Common Transient Visitant ; rare Summer Resident, April 28 to October 7.

Barn Swallow.-Common Summer Resident ; more abundant Transient Visitant, March 28 to September.

Cliff Swallow.-Common Summer Resident; more common Transient Visitant, April 15 to September 21.

Bank Swallow.-RareSummer Resident, A pril to September. Tree Swallow.-Common Transient Visitant, April 1 to May 25 ; July 10 to September.

Purple Martin.--Rather common Summer Resident, April 12 to September 15.

Cedar Waxwing.-Very common Permanent Resident; less so in winter.

Northern Shrike.-Rare and irregular Winter Visitant, November to February.

Red-eyed Vireo.-Very common Summer Resident, April 25 to October 15.

Warbling Vireo.-Rather common Summer Resident, April 28 to September 10. 
Yellow-throated Viren.-Common Summer Resident, A pril 20 to September 15.

White-eyed Vireo.-Common Summer Resident, Apri] 20 to October 7.

Black and White Warbler.-Abundant Transient Visitant ; less coumon Sunmer Resilent, April 12 to Octoler 15.

Yellow Warbler,-Common Summer Resident ; abundant Transient Visitant, A pril 18 to September 30.

Myrtle Warbler. - Abundant Winter Visitant, September 28 to May 20.

Black-throated Green Warbler.-Very common Transient Visitant, April 25 to May 28; August 28 to October 20.

Redstart. - Very abundant Transient Visitant, April 18 to May 28 ; August 19 to September 15.

Oven-bird.-Very common Summer Resident, April 20 to October 15.

Maryland Yellowthroat.-Abundant Summer Resident, April 18 to October 20.

Chat.-Common Summer Resident, A pril 29 to September. Catbird.-Abundant Summer Resident, April 20 to October ; occasionally winters.

Mockingbird.-Uncommon Permanent Resident; less numerous in winter.

Brown Thrasher.-Very common Summer Resident, April 5 to October 15 ; occasionally winters.

House Wren.-Common Summer Resident, April 15 to September.

Winter Wren.-Rather common Winter Visitant, Septem. ber 25 to May.

Carolina Wren.-Common Permanent Resident.

Long-billed Marsh Wren.-Very numerous Summer Resident, April 30 to October.

Brown Creeper.-Common Winter Visitant, September 25 to April 25.

Carolina Chickadee.-Very common Permanent Resident, particularly in winter.

Tufted Titmouse.-Very common Permanent Resident, more so in winter. 
White-breasted Nuthatch.-Common Transient Visitant, and Winter Visitant; less common Summer Resident.

Red-breasted Nuthatch. - Irregularly abuudant Winter Visitant, sometimes rare, September 15 to May 10.

Golden-crowned Kinglet.-Abundant Winter Visitant, October 5 to April 27.

Ruby-crowned Kinglet.-Abundant Transient Visitant, April 5 to May 10 ; September 25 to November 1 ; occasionally winters.

Veery.-Common Transient Visitant, April 26 to May 28; August 20 to September 30.

Wood Thrush.-Common Summer Resident, April 20 to October 15.

Hermit Thrush.-Very common Transient Visitant ; sometimes not uncommon Winter Visitant, April 4 to May 15 ; October 15 to November.

Robin.-Rather common Summer Resident; abundant Transient Visitant from February to April ; irregularly common in winter.

Bluebird.-Common Permanent Resident.

NOTES FROM A LOCALTTY SLIGHTLY NORTH OF PHILADELPHIA, PA., ON THE BIRDS INCLUDED IN "BIRD-LIFE."

By Wrtmer Stone.

Pied-billed Grebe.-Common Transient Visitant.

Loon.-Tolerably common Transient Visitant and less frequent Winter Visitant, October 5 to May 1.

Herring Gull.-Common Winter Visitant, October 1 to April 1.

Common Tern.-Occasional in August.

Wood Duck.-Tolerably common Transient Visitant; occasional Winter Visitant and Summer Resident.

Pintail.-Tolerably common Transient Visitant.

Mallard.-Not common Transient Visitant. 
Grven-winged Teal.-Tolerably common Trunsient Visitant. Blue-winged Teal.-Common Transient Visitant.

Canada Goose.-Conmon Transient Visitunt, October 15 to April 15.

Great Blue Heron.-Tolerably common Summer Resident, A pril 1 to November 15: rare in winter.

Little Green Heron.-Common Summer Resident, April 1 to October 1.

Black-crowned Night Heron.-Common Summer Resident, A pril 15 to Oetober 15; rare Winter Visitant.

American Bittern.-Tolerably Common Transient Visitant, A pril and September to November.

Sora.-Very common Transient Visitant, April and May, September and October.

Clapper Rail.-Very rare in Summer; very common Summer Resident at Atlantic City, N. J., April 15 to November 1.

Coot.-Not common Transient Visitant; occasional Winter Visitant.

Woodcock.-Formerly common Summer Resident, now rather rare and mainly Transient Visitant and occs. sional Winter Visitant.

Spotted Sandpiper.-Very common Summer Resident. April 20 to October 1.

Wilson's Snipe.-Tolerably common Transient Visitant. March 20 to May 10, and October, and occasional Winter Visitant.

Semipalmated Sandpiper.-Rare. Abundant Transient Visitant at Atlantic City, N. J., July 10 to October 1.

Killdeer.-Tolerably common Sumuer Resident; oceasional Winter Visitant. March 20 to October 25.

Semipulnated Plover.-Rare. Common Transient Visitant at Atlantic City, N. J., May 10 to June 1 ; July 19 to September 15.

Bob-white. - Formerly common Permanent Resident : scarcer in winter ; now becoming rare and mainly Transient Visitant.

Ruffed Grouse.-Formerly common Permanent Resident; now rave ; mainly in fall. 
Mourning Dove.-Common Summer Resident and occasional Winter Visitant ; March to November.

Turkey Vulture.-Tolerably common Summer Resident; occasional Winter Visitant.

Red-shouldered Hawk. - Tolerably common Permanent Resident.

Red-tailed Hawk.-Common Winter Visitant; not common in summer.

Marsh Hawk. - Common Winter Visitant (rare Summer Resident ?)

Sparrow Hawk.-Common Permanent Resident.

Sharp-shinned Hawk.-Common Permanent Resident.

Cooper's Hawk.-Tolerably common Permanent Resident; very common Transient Visitant.

Bald Eagle.-Not Common Permanent Resident.

Osprey.-Tolerably common in Summer; very common Summer Resident on New Jersey coast and Delaware Bay, March 20 to October 15.

Short-eared Owl.-Irregularly common Winter Visitant.

Long-eared Owl.-Not common Permanent Resident.

Screech Owl.-Very common Permanent Resident.

Barred Owl.-Rare; mostly in winter.

Yellow-billed Cuckoo.-Common Summer Resident, May 8 to October 1.

Black-billed Cuckoo.-Rare Summer Resident ; tolerably common Transient Visitant, May 8 to October 1.

Kingfisher.-Common Summer Resident; occasional Winter Visitant.

Downy Woodpecker.-Common Permanent Resident.

Hairy Woodpecker.-Rare; mainly in winter.

Red-headed Woodpecker.-Irregularly common Transient

Visitant in fall; tolerably common Summer Resident, but local ; occasional Winter Visitant.

Flicker.-Very common Summer Resident, March 25 to October 25 ; occasional during winter.

Nighthawk. - Common Transient Visitant; tolerably common, but rather local Summer Resident, May 4 to October 10.

Whip-poor-will.-Tolerably common Transient Visitant; 
comnon Summer Resident in New Jemsey, within twen. ty miles of Philadelphia; April 22 w Saphruber 30.

Swift. - Very common Summer Resident, April 15 to Octuber 10.

Ruby-throated Hummingbird-Common Summer Rusident, May 7 to September 25.

Kingbird.-Common Summer Resident, May 1 to Septeuber 1.

Crested Flycatcher.-Common Summer Resident, May 1 to September 1.

Phoebe-Common Summer Resident; occasional Winter Visitant, March 20 to October 25.

Least Flycatcher. - Tolerably common Trausient Visitor, May 1 to 15 ; September 6 to 15.

Wood Pewee.-Common Summer Resident, May 6 to September 20.

Horned Lark. - Irregular Winter Visitant.

Crow.-Very common Permanent Resident.

Blue Jay.-Common Permanent Resident; less abundant in winter; most plentiful in fall.

Baltimore Oriule.-Tolerably conmon Summer Resident, May 1 to September 1.

Orchard Oriole.-Common Summer Resident, May 1 to September 1.

Red-winged Blackbird.-Common Summer Resident, February 20 to November; rather common Winter Visitant.

Purple Gruckle.-Common Summer Resident, February 20 to November; occasional Winter Visitant.

Bobolink. - Tolerably common Transient Visitant, May 1 to 15 ; common Transient Visitant, August 23 to September 20.

Meadowlark. - Common Permunent Resident.

Cowbird. - Common Summer Resident, April 1 to October; occasional Winter Visitant.

Song Sparrow. - Abundant Permanent Resident.

Swanp Sparrow. - Tolerably common Permanent Resident: more abundant in migrations.

Field Sparrow. - Very common Summer Rexident, March 18 to October; occasional Winter Visitant. 
Vesper Sparrow.-Common Summer Resident, April 2 to

November 1; occasional Winter Visitant.

Chipping Sparrow.-Common Summer Resident, March 30 to October 20.

White-throated Sparrow. - Very Common Transient Vis-

itant, September 20 to May 20; Common Winter Visitant.

White-crowned Sparrow.-Rare Transient Visitant, May 2

to 13 ; Octolver 6 to 20.

Fox Sparrow.-Very common Transient Visitant, March

10 to April 10; October 15 to December 1; occasional

Winter Visitant.

Junco.-Very common Winter Visitant, October 1 to May 1. Tree Sparrow.-Very common Winter Visitant, October

15 to April 15.

Redpoll.-Rare and irregular Winter Visitant.

Snowflake,-Rare and irregular Winter Visitant.

American Crossbill.-Rather rare and irregular Winter

Visitant; has been seen in May.

Pine Grosbeak.-Only casual Winter Visitant.

Goldfinch.-Very common Permanent Resident.

Purple Finch.-Tolerably common Winter Visitant, Sep-

tember 25 to May 1; very common Transient Visitant.

Rose-breasted Grosbeak.-Tolerably common Transient

Visitant, May 5 to May 12 ; September 5 to October 5.

Towhee.-Common Summer Resident, April 18 to October 20.

Indigo Bunting.-Common Summer Resident, May 10 to October 1.

Cardinal._-Tolerably common Permanent Resident.

Scarlet Tanager.-Common Transient Visitant, May 5 to

May 18; September 10 to October 10 ; tolerably common

Summer Resident.

Barn Swallow.-Common Summer Resident, April 14 to September 1.

Cliff Swallow.-Tolerably common Transient Visitant; rare Summer Resident, May 1 to September 1.

Bank Swallow.-Common but local Summer Resident, April 8 to April 20 ; September 1.

Tree Swallow.-Common Transient Visitant, April 20 to 
May 15; August 15 to Septemiber 1; common Summer Resident in Now Jersey, within twenty uiles of Plidadelphia.

Purple Martin.-Irregular and local Summer Resident, April 15 to September 1.

Cedar Waxwing.-Tolerably common Summer Resident: abundant Transient Visitant; occusional Winter Visitunt. Northern Shrike. - Rather rare Winter Visitant, December 2 to February 5.

Red-eyed Vireo.-Very common Summer Resident, A pril 30 to October 10.

Warbling Vireo,-Not very common Summer Resident, May 5 to October 10.

Yellow-throated Vireo.-Tolerably common Summer Resident, May 2 to September 15.

White-eyed Vireo.-Cummon Summer Resident, May 5 to October 1.

Black and White Warbler.-Very common Transient Visitant, April 23 to May 15 ; August 10 to Octolver 5 ; less common Summer Resident.

Yellow Warbler.-Common Summer Resident, May 1 ts Septemiber 25.

Myrtle Warbler.-Very common Transient Visitant, April 15 to May 20 ; September 25 to November 1 ; found sparingly, Winter Visitant.

Black-throated Green Warbler.-Common Transient Visitant, May 1 to May 15 ; September 1 to October 10.

Redstart. - Very common Transient Visitant ; a few breed : A pril 30 to May 20; August 5 to October 5.

Oven-bird.-Common Summer Resident, April 30 to October 6.

Maryland Yellowthroat. - Very common Summer Resident, April 2s to October 12.

Clat.-Common Summer Resident. May 5 to September 20.

Catbird.-Very common Summer Resident, May 3 to October 18 ; one winter record.

Mockingbird.-Rare straggler.

Brown Thrasher.-Common Summer Resident, April 22 tn October 20 ; occasioual in winter ; a few records. 
House Wren.-Tolerably common Summer Resident, April 25 to October 5.

Winter Wren.-Common Winter Visitant, September 25 to April.

Carolina Wren.-Tolerably common Permanent Resident. Long-billed Marsh Wren.-Common Summer Resident; a few winter.

Brown Creeper.-Common Transient Visitant; less common Winter Visitant, September 20 to April 15.

Black-capped Chickadee.-Not common Winter Visitant, October 24 to March 1.

Tufted Titmouse.-Rather common Permanent Resident.

White-breasted Nuthatch.-Common Permanent Resident ; less numerous in summer.

Red-breasted Nuthatch.-Transient Visitant; irregularly abundant in fall; rare in spring; May 15 to September 10 ; October 15 to May 15 ; and occasional Winter Visitant.

Golden-crowned Kinglet.-Very common Transient Visitant, September 30 to April 20 ; rather common Winter Visitant.

Ruby-crowned Kinglet.-Common Transient Visitant, April 12 to May 1; September 15 to November 1.

Veery.-Common Transient Visitant, May 5 to 25 ; September 1 to 20 .

Wood Thrush.-Common Summer Resident, May 1 to October 1.

Hermit Thrush. - Very common Transient Visitant ; found sparingly as Winter Visitant; April 10 to May 4 ; October 10 to November 5 .

Robin.-Abundant Summer Resident ; frequent but irregular Winter Visitant; March 15 to November 10.

Bluebird.-Tolerably common Transient Visitant; rather rare Summer Resident; formerly Permanent Resident. Begiuning to increase again. 
NOTES FROM PORTLAND, CONN., ON THE BIKDS INCLUDED IN "BIRD-L.TFE。"

\section{By Johs H. SAgr.}

Pied-billed Grebe.-Transient Visitant, April 12 ; common, September 9 to November 22.

Loon.-Not common, Transient Visitant, April 21 ; September 25 to December 1.

Herring Gull.-Not common Winter Visitant, October 6 to Marels 8.

Wood Duck.-Common Transient Visitant, March 20 to A pril 8 ; September to December 3 ; a few breed. Pintail.-Casual Transient Visitant, October 9 to 12.

Mallard.-Rare Transient Visitant, November 5.

Green-winged Teal.-Uncommon Transient Visitant, A pril 6 to 8 ; September to Novenber 26.

Blue-winged Teal.-Uncommon Transient Visitant in fall, September 13 to October 20.

Canada Goose.-Common Transient Visitant, March 10 to May 8 ; October 13 to Decenber 15.

Great Blue Heron.-Common Transient Visitant, April 3 to May 11; August 21 to November 25.

Little Green Heron.-Common Summer Resident, April 28 to October 14.

Black-crowned Night Heron.-Uncommon Summer Resident, April 15 to October 14.

American Bittern. - Not common Summer Resident, April 8 to October 24.

Sora.-Summer Resident, A pril to November 5.

Coot.-Transient Visitant, rare in April and May; common. September 19 to Novemler 14.

Woodenck.-Conımon Sumuer Resident, February 25 to November 28.

Spotted Sandpiper.-Common Summer Resident, April 22 to September 20.

Wilson's Snipe.-Common Transient Visitant, March 18 to 
May 10 ; September 14 to November 30 ; one instance of breeding.

Semipalnuated Sandpiper.-Common Transient Visitant in fall, August to October 7.

Killdeer.-Accidental Visitant, not seen since April 5, 1875. Semipalmated Plover.-Transient Visitant, May 22 to June

4 ; September.

Bob-white.-Common Permanent Resident.

Ruffed Grouse.-Common Permanent Resident.

Mourning Dove.-Common Summer Resident, March 19 to

November 30 ; occasional in winter.

Red-shouldered Hawk.-Common Permanent Resident; less common in winter.

Red-tailed Hawk.-Common Permanent Resident; less common in winter.

Marsh Hawk.-Tolerably common Summer Resident, April 1 to November 2.

Sparrow Hawk.-Rather rare Permanent Resident.

Sharp-shinned Hawk.-Common Summer Resident, March 27 to October 29 ; a few winter.

Cooper's Hawk.-Common Summer Resident, March 18 to October 15.

Bald Eagle.-Of irregular occurrence, April, May, June, and December.

Osprey.-Common Transient Visitant, April 5 to May 25 ; September 7 to October 18.

Short-eared Owl.-Common Transient Visitant, April ; October 8 to December 7 .

Long-eared Owl.-Probably a Permanent Resident. Not uncommon in winter.

Screech Owl.-Common Permanent Resident.

Barred Owl.-Rare Permanent Resident, sometimes common in October, November, and December.

Yellow-billed Cuckoo. - Common Summer Resident, May 7 to October 17.

Black-billed Cuckoo.-Common Summer Resident, May 1 to September 4.

Kingfisher.-Common Summer Resident, April 5 to November 22 ; casual in winter. 
Downy Woodpecker.-Common Permanent Resident. Hairy Woodpecker. - Rare Permanent Resident.

Rod-headed Woodpecker,-Rare Permanent Resident, sometimes common in fall: September 20 to November 28.

Flicker.-Common Summer Resident, March 8 to Novem. ber 20 ; a fow winter.

Nighthawk.-Common Summer Resident, April 28 to October 3.

Whip-poor-will.-Common Summer Resident, April 23 to September 25.

Swift.-Abundant Summer Resident, April 19 to October 11.

Ruby-throated Hummingbird.-Common Summer Resident, May 6 to September 22.

Kingbird.-Common Summer Resident, April 28 to September 10.

Crested Flycatcher.-Common Summer Resident, May 4 to August

Phobe.-Common Summer Resident, March 7 to October 14.

Least Flycatcher.-Common Summer Resident, April 21 to Septomber 4.

Wood Pewee.-Common Summer Resident, May 6 to October 3.

Horned Lark.-Casual; March 22 to 25 ; no fall record.

Crow.-Common Permanent Resident.

Blue Jay. - Common Permanent Resident.

Baltimore Oriole.-Common Summer Resident, May 1 to September 8.

Orchard Oriole.-Summer Resident, May 10 to August.

Red-winged Blackbird. - Common Summer Resident, March 3 to November 1.

Bronzed Grackle.-Common Summer Resident, February 20 to November 8.

Bobolink, - Common Summer Resident, May 3 to October 15.

Meadowlark.-Common Sumumer Resident, March 8 to October 20; a few winter.

Cowbird.-Common Summer Resident, Manch 26 to November 6 ; occasional in winter. 
Song Sparrow.-Permanent Resident; more common from

March 5 to November 2.

Swamp Sparrow.-Not common Summer Resident, April

12 to November 2.

Field Sparrow.-Common Summer Resident, April 6 to

October 26; occasional in winter.

Vesper Sparrow.-Common Summer Resident, April 4 to October 21.

Chipping Sparrow.-Abundant Summer Resident, April 5 to October 23.

White-throated Sparrow. - Very common Transient Vis-

itant, April 13 to May 21; September 18 to November 12 ; occasional in winter.

White-crowned Sparrow.-Uncommon Transient Visitant,

May 12 to 22; October 2 to 16.

Fox Sparrow.-Abundant Transient Visitant, March 2 to

April 26; October 17 to November 27.

Junco.-Common Winter Visitant, September 28 to April 26.

Tree Sparrow.-Common Winter Visitant, October 26 to April 23.

Redpoll.-Irregular Winter Visitant, November 27 to March 31.

Snowflake.-Rather common Winter Visitant, October 25 to March 20.

American Crossbill.-Irregular in occurrence, December 10 to April 19.

Pine Grosbeak.-Irregular Winter Visitant, November 25 to March 25.

Goldfinch.-Common Permanent Resident.

Purple Finch.-Rather rare Permanent Resident; common

Transient Visitant; irregular, but sometimes common in winter.

Rose-breasted Grosbeak.-Common Summer Resident, May 1 to September 28.

Towhee.-Common Summer Resident, April 27 to Octoker 24.

Indigo Bunting.-Common Summer Resident, May 6 to

October 16. 
Scarlet Tanager.-Common Summer Resident, May 3 to October 7.

Barn Swallow.-Common Summer Resident, April 16 to October 19.

Cliff swallow. - Summer Resident, less common than formerly, May 12 to September 14.

Bank Swallow.-Common Summer Resident, April 17 to September 25.

Tree swallow. - Summer Resident, but common only as a migrant, April s to Oetober 26.

Purple Martin.-Locally common Summer Resident, A pril 16 to September 12.

Cedar Waxwing.-Common Permanent Resident.

Northern Shrike.-Tolerably common Winter Visitant, October 26 to April 3.

Red-eyed Vireo.-Abundant Summer Resident, April 30 to October 8.

Warbling Vireo.-Common Summer Resident, April 29 to September 17.

Yellow-throated Vireo.-Common Summer Resident, April 26 to September 21.

White-eyed Vireo.-Common Summer Resident, May 3 to September 20.

Black and White Warbler.-Common Summer Resident, April 27 to October 6.

Yellow Warbler.-Common Summer Resident. A pril 29 to September 23.

Myrtle Warbler.-Common Transient Visitant, A pril 22 to May 19; September 21 to October 25; a few winter.

Black-thronted Green Warbler, - Tolerably common Sum. mer Resident, April 27 to October 21.

Redstart.-Common Summer Resident, May 2 to September 26.

Oven-bird. - Abundant Summer Resident, May 4 to Septem. ber 26.

Maryland Yellowthroat.-Abundant Summer Resident. May 3 to November 7.

Chat. - Common Summer Resident, May 6 to August.

Cathird.-Common Summer Residenth A pril 30 wo October 14. 
Brown Thrasher.-Common Summer Resident, April 22 to October 20.

House Wren.-Tolerably common Summer Resident, April 21 to September 26.

Winter Wren.--Rather common Winter Visitant, September 23 to March 12.

Carolina Wren.-Accidental Visitant, March.

Long-billed Marsh Wren.-Locally abundant Summer Resident, May 18 to October 26.

Brown Creeper.-Tolerably common Winter Visitant, October 2 to May.

Black-capped Chickadee-Common Permanent Resident.

White-breasted Nuthatch.-Tolerably common Permanent Resident.

Red-breasted Nuthatch.-Irregular Winter Visitant, September 18 to May 11.

Golden-crowned Kinglet.-Common Winter Visitant, October 8 to April 25.

Ruby-crowned Kinglet.-Common Transient Visitant, April 8 to May 6 ; September 26 to October 26.

Veery.-Common Summer Resident, May 3 to August 30. Wood Thrush.-Common Summer Resident, May 4 to September 18.

Hermit Thrush.-Common Transient Visitant, April 6 to May 3; October 15 to 26; occasional in winter.

Robin.-Common Summer Resident, February 15 to November 21; a few winter.

Bluebird.--Common Permanent Resident.

\section{NOTES FROM CAMBRIDGE, MASS., ON BIRDS INCLUDED IN "BIRD-LIFE."}

By William Brewster.

Pied-billed Grebe.-Common in April ; very common September to November; breeds in one locality.

Loon.-Not common Transient Visitant, April to early May ; September to November. 
Herring Gull.-Abundant Winter Visitant, November to April.

Common Tern. - C.sual in September.

Wood Duck.-Common Transient Visitant, March and A pril; A ugust to November; a few breed.

Pintail.-Casual Transient Visitant, April, September and October.

Green-winged Teal.-Uncommon Transient Visitant, A pril; September to November.

Blue-winged Teal. - Rare in spring; very common, at least formerly, August to October.

Canada Goose.-Common Transient Visitant, March and April; October to December.

Great Blue Heron.-Common Transient Visitant, April and May; September to November; occasional in sumner.

Little Green Heron.-Common Summer Resident, May 6 to September.

Black-erowned Night Heron.-Permanent Resident, most common in August and September.

American Bittern. - Not common Summer Resident, April 15 to November.

Sora.-Very common Summer Resident, April 20 to October 20.

Coot. - Transient Visitant, rare in April; common September to November.

Woodenck. - Summer Resident, formerly common, fast becoming rare; March to November.

Spotted Sundpiper.-Common Summer Resident, A pril 26 to September.

Wilsun's Snipe-Common Transient Visitant, April 5 to May 5; September and October.

Semipalmated Sandpiper.-Very common in August and September.

Killdeer.-Accidental Visitant; two instances.

Semipalmated Plover.-Rure in spring ; sometimes com mon in August and September.

Bob-white-Common Permanent Resident.

Ruffed Grouse.-Common Permanent Resident. 
Mourning Dove.-Occasional during summer in immediate vicinity of Cambridge.

Red-shouldered Hawk.-Common Permanent Resident; less common in winter.

Red-tailed Hawk.-Common Winter Visitant, November to April ; a fow in summer.

Marsh Hawk.-Common Transient Visitant, March 15 to April 15; September and October ; a few breed.

Sparrow Hawk.-Rather common Summer Resident, February to November.

Sharp-shinned Hawk.-Uncommon Transient Visitant, April 15 to April 30 ; September and October; rare Summer Resident; uncommon Winter Visitant.

Cooper's Hawk.-Common Transient Visitant, April, September, and October; not common Summer Resident; rare Winter Visitant.

Bald Eagle.-Of irregular occurrence at all seasons.

Osprey.-Common Transient Visitant, April ; September.

Short-eared Owl.-Uncommon Transient Visitant, April, October, and November.

Long-eared Owl.-Not common Permanent Resident.

Serecch Owl.-Common Permanent Resident.

Barred Owl.-Rare Permanent Resident, sometimes common in November and December.

Yellow-billed Cuckoo.-Common Summer Resident, May 12 to August.

Black-billed Cuckoo.-Common Summer Resident, May 15 to September 20.

Kingfisher.-Common Summer Resident, April 10 to October.

Downy Woodpecker.-Common Permanent Resident.

Hairy Woodpecker.-Uncommon Winter Visitant.

Red-hearled Woodpecker.-Irregular at all seasons ; sometimes common in fall.

Flicker.-Very common Summer Resident; common Winter Visitant.

Nighthawk. - Not uncommon Summer Resident, May 15 to September 25. 
Whip-poor-will.-Common Summer Resident, A pril 28 to September 20.

Swift. - Abundant Summer Resident, April 25 to September 20.

Ruby-Lhroated Hummingbird.-Uncommon Summer Resi. dent, May 12 to September.

Kingbird. -Abundant Summer Resident, May 5 to September 1.

Crested Flycatcher.-Uncommon Summer Resident, May 15 to August.

Phoebe. - Common Summer Resident, March 25 to October 10.

Least Flycatcher. - Abundant Summer Resident. Mny 1 to August 25.

Wood Pewee.-Common Summer Resident, May 18 to September 10.

Horned Lark. - Common Transient Visitant, October 25 to November 25; March 25 to April 5.

Crow. - A bundant Permanent Kesident.

Blue Jay.-Common Permanent Resident ; abundant Transient Visitant, April and May; September and October. Baltimore Oriole.-Very common Summer Resident, May 8 through August.

Orchard Oriole. - Summer Resident, sometimes rather common May 15 to July.

Red-winged Blackbird.-Abundant Summer Resident, March to August; a few winter.

Bronzed Grackle.-A Abundant Summer Resident, March to October; occasional in winter.

Bobolink.-Very common Summer Resident, May 8 to September 10.

Meadowlark.-Common Summer Resident; not common Winter Visitant.

Cowbird.-Very common Summer Resident, May 8 to September 10.

Song sparrow. - Very abundant Summer Resident, March

10 to November 1 ; locully common Winter Visitant.

Swamp Sparrow.-Abundant Summer Resident, A pril 12 to November 10 ; a fow winter. 
Field Sparrow.-Common Summer Resident, April 15 to November 1.

Vesper Sparrow. - Very common Summer Resident, April 5 to October 15.

Chipping Sparrow.-Abundant Summer Resident, April 15 to October 25.

White-throated Sparrow.-Very common Transient Visitant, April 25 to May 15; October 1 to November 10; a few winter.

White-crowned Sparrow.-Uncommon Transient Visitant, May 12 to 22; October 1 to 20.

Fox Sparrow.-Abundant Transient Visitant, March 15 to April 20 ; October 20 to November 15.

Junco.-Rather common Winter Visitant; abundant Transient Visitant, September 20 to November 25; March 20 to April 20.

Tree Sparrow.-Common Winter Visitant; abundant Transient Visitant, October 25 to November 25 ; March 20 to April 20.

Redpoll.-Irregular Winter Visitant, often very abundant, October 25 to April 10.

Snowflake-Common Winter Visitant, October 25 to March 25; abundant in migrations.

American Crossbill. - Of irregular occurrence at all seasons. Pine Grosbeak. - Irregular Winter Visitant, frequently common; sometimes abundant November to March.

Goldfinch.-Very common Permanent Resident.

Purple Finch.-Permanent Resident, very common from March to October ; irregular, but at times abundant in winter.

Rose-breasted Grosbeak. -Common Summer Resident, May 10 to September 10.

Towhee.-Common Summer Resident, April 25 to October 15 .

Indigo Bunting.- Rather common Summer Resident, May 15 to September 25.

Cardinal.-Casual ; two instances.

Scarlet Tanager.-Rather conmon Summer Resident, May 12 to October 1. 
Barn Swallow.-Common Sumıner Resident, but fast decreasing. A pril 20 to September 10.

Cliff Swallow. - Summer Resident, much less common than formerly, A pril 28 to September 1.

Bank Swallow.-Common Summer Resident, April 28 to September 1.

Tree Swallow. - Summer Resident, formerly common, now common only as a migrant, April 5 to Ocwher 12.

Purple Martin.-Locally common Summer Resident, April 20 to August 25.

Cedar Waxwing.-Not common Permanent Resident; common Summer Resident; abundant Transient Visitant, in spring, Fehruary 1 to $\mathrm{A}$ pril 25.

Northern Shrike.-Common Winter Visitant, Nurember 1 to April 1.

Red-eyed Vireo.-Abundant Summer Resident, May 10 to September 10.

Warbling Vireo.-Common Summer Resident, May $10 \mathrm{t}$ September 25.

Yellow-throated Vireo.-Common Summer Resident, May 8 to September 1.

White-eyed Vireo.-Rather rare Summer Resident, May 8 to September 20 ; formerly common.

Black and White Warbler.-Very common Summer Resi. dent, April 25 to September 5.

Yellow Warbler.-Abundant Summer Resident, May 1 to September 30.

Myrtle Warbler.-Abundant Transient Visitant, April 18 to May 20 ; September 20 to November 3 ; a few winter.

Black-throated Green Warbler.-Very common Summer Resident, May 1 to October 18.

Redstart. - Very common Summer Resident, May 5 to September 20.

Oven-bird.-Abundant Summer Resident, May 6 to September 15.

Maryland Yellow-throat. - Abundant Summer Resident, May 5 to October 20.

Chat.-Rather rare Sunmer Resident, May 15 to (n). 
Catbird.-Abundant Summer Resident, May 6 to September 30 .

Mockingbird,-Rare Summer Resident, March to November.

Brown Thrasher.-Very common Summer Resident, April 25 to Octolver 15.

House Wren.-Locally common Summer Resident, May 1 to September 25.

Winter Wren.-Transient Visitant, rather common, Septeinber 20 to November 25 ; rare, April 10 to May 1; a very fow winter.

Long-billed Marsh Wren.-Locally abundant Summer Resident, May 15 to October; sometimes a few winter.

Brown Creeper.-Common Transient Visitant, rather common Winter Visitant, September 25 to May 1.

Black-capped Chickadee.-Very common Permanent Resident ; more numerous in fall and winter.

White-breasted Nuthatch.-Permanent Resident, rare in summer, uncommon in winter ; common in migrations.

Golden-crowned Kinglet.-Very common Transient Visitant ; common Winter Visitant, September 20 to April 25.

Ruby-crowned Kinglet.-Rather common Transient Visitant, April 10 to May 5 : October 10 to November 5.

Veery.-Very common Summer Resident, May 10 to September 8.

Wood Thrush. - Rather common Summer Resident, May 12 to September 15.

Hermit Thrush. - Very common Transient Visitant, April 16 to May 5 ; October 5 to November 15 ; occasionally one or two may winter.

Robin. - Very abundant Summer Resident ; irregular Winter Visitant.

Bluebird.-Common Summer Resident, March 6 to November 1 ; more numerous during March and November. 
NOTES FROM THE NEIGHBORHOOD OF ST. LOUIS, MO., INCLUDING PARTS OF ST. LOUIS AND ST. CHARLES COUNTIES, ON THE BIRDS IN. CLUDED IN "BIRD-LIFE."

\section{By Otto Wivaskx.}

Pied-billed Grebe-Common Transient Visitant; rare Summer Resiclent, April 1 to December 1.

Loon.-Rare Transient Visitant, A pril and October.

Herring Gull.-Transient Visitant and Winter Resident, less common thun formerly. September 20 to May 5.

Conmon Tern.-Rare Transient Visitant, May and September.

Wood Duck. - Breeds frequently ; common in migrations in February and March ; September and October.

Pintail.-Abundant Transieut Visitant, February 13 to A pril 15; October 10 to December 1.

Mallard._A bundant Transient Visitant and frequent Winter Resident, September 15 to April 25.

Green-winged Teal.-Abundant Transient Visitant and occasional Winter Resilent, February 15 to April 25 ; October 1 to December 18.

Blue-winged Teal.-A bundant Transient Visitant, Septomber 1 to December 1.

Canada Goose. - Abundant Winter Visitant, October 15 to April 1.

Great Blue Heron.-Common Summer Resident, April 1 to November 1.

Little Green Heron.-Common Summer Resideat, April 10 to October 10.

Black-crowned Night Heron.-Tolerably common Summer Resident, A pril 10 to Oet. 10.

American Bittern.-Rather rare Summer Resident, April 10 to October 20.

Sora.-Tulerably common Summer Resident and very common Transient Visitant, April 10 to November 1. 
American Coot. - Tolerably common Summer Resident and very common Transient Visitant, April 1 to November 1.

Woodcock.-Comimon Summer Resident, March 1 to November 15.

Spotted Sandpiper.-Common Summer Resident, April 15 to October 15.

Wilson's Snipe.-Common Transient Visitant, March 1 to May 1 ; September 6 to November 20.

Semipalmated Sandpiper.-Irregular Transient Visitant, May; August 4 to October 17.

Killdeer.-Common Transient Visitant; infrequent Summer Resident, March 10 to November 15.

Semipalmated Plover.-Tolerably common Transient Visitant, April 26 to May 5 ; August 20 to September 17. Bob-white.-Abundant Permanent Resident.

Ruffed Grouse.-Permanent Resident in hilly region south of St. Louis.

Mourning Dove. -Abundant Summer Resident; rare Win. ter Resident, March 10 to November 1.

Turkey Vulture.-Common Summer Resident, February 25 to November 1.

Red-shouldered Hawk. - Common Permanent Resident.

Red-tailed Hawk.-Common Permanent Resident, most numerous in fall and early winter.

Marsh Hawk.-Common Permanent Resident.

Sparrow Hawk.-Common Permanent Resident.

Sharp-shinned Hawk. - Fairly common Transient Visitant, February, March ; October to December.

Cooper's Hawk. - Rather rare Summer Resident; Transient

Visitant, more common in fall, September 15 to November 1 ; February 15 to March 15; sometimes winters.

Bald Eagle.-Winter Resident, becoming scarce, Septem. ber 1 to April 1.

Osprey.-Rather common Summer Resident, April 1 to October 1.

Short-eared Owl.-Tolerably common Winter Visitant, October 8 to April 1.

Long-eared Ow1.-Not common Winter Visitant. 
Sereech Owl.-Common Permanent Resident.

Barred Owl.-Common Permanent Resident.

Yellow-billed Cuckoo-Common Summer Resident, A pril 28 to October 23.

Black-billed Cuckoo.-Rare Summer Resident ; fairly com. mon Transient Visitant, May 1 to Octuber 15.

Kingfisher.-Common Summer Resident, March 1 to November 1.

Downy Woolpecker.-Common Permanent Resident.

Hairy Woodpecker. - Fairly con.mon Permanent Resi. dent.

Red-headed Woodpecker.-Common Summer Resident and frequent Winter Resident, A pril 15 to October 1.

Flicker.-Common Summer Resident and frequent Winter Resident, May 15 to October 15.

Nighthawk.-Common Transient Visitant and tolerably common Summer Resident, April 25 to Oetober 13. Bulk of Transient Visitants, May 5 to 25 ; August 25 to September 15.

Whip-poor-will.-Common Summer Resident, April 8 to October 10.

Chimney Swift.-Abundart Summer Resident, April 1 to October 20.

Ruby-throated Hummingbird.-Common Summer Resident, April 25 to October 20.

Kingbird.-Common Summer Resident, April 10 to September 1.

Crested Flycatcher.-Common Summer Resident, A pril 20 to September 1.

Phoobe.-Summer Resident, less common than formerly. March 1 to November 1.

Least Flycatcher.-Fairly common Transient Visitant, A pril 28 to May 15 ; September 1 to Octuber 15.

Wond Pewee.-Counmon Summer Resident, April 28 to October 1.

Prairie Horned Lark. - Common Permanent Ressident.

American Crow.-Common Permanent Resideut; abun. dant Winter Resident.

Blue Jay. - Abundant Permanent Resident. 
Baltimore Oriole.-Common Summer Resident, April 20 to September 10.

Orchard Oriole.-Common Summer Resident, April 20 to September 1.

Red-winged Blackbird.-Common Summer Resident ; abundant Transient Visitant; frequent Winter Resident, March 1 to May 15 ; September 15 to November 15.

Bronzed Grackle.-Abundant Summer Resident and Transient Visitant: rare Winter Resident, March 10 to May 1; October 1 to November 15.

Bobolink.-Tolerably common Transient Visitant, April 28 to May 28; August 20 to September 24.

Meadowlark.-Common Summer Resident; rare Winter Resident, March 10 to November 1.

Cowbird.-Common Summer Resident; rare Winter Resident; abundant Transient Visitant, March 10 to May 1; September 15 to November 1.

Song Sparrow.-Common Transient Visitant; fairly common Winter Resident; rare Summer Resident; March 10 to A pril 15; September 20 to November 10.

Swamp Sparrow.-Common Transient Visitant; rare Winter Resident, March 15 to May 15; September 20 to November 10.

Field Sparrow.-Common Summer Resident, March 10 to November 1.

Vesper Sparrow.-Tolerably common Transient Visitant, March 25 to April 10; October 15 to November 1.

Chipping Sparrow.-Common Summer Resident, March 15 to October 25.

White-throated Sparrow.-Abundant Transient Visitant; fairly common Winter Resident, March 10 to May 25; September 25 to November 10.

White-crowned Sparrow.-Rare Winter Resident; common Transient Visitant, April 20 to May 20; October 1 to November 1.

Fox Sparrow.-Common Transient Visitant; fairly common Winter Resident, March 10 to April 12; October 7 to November 10.

Junco.-Abundant Transient Visitant and very common 
Winter Resident, March 10 to April 20; September 20 to Novernber 15.

Tree Sparrow, - Common Winter Resident, November 1 to April 1.

Relpoll.--Rare Winter Visitant, Janunry and February.

American Crosshill. - Rare Trunsient Visitant, February 22 to April 1 ; middile of November.

Goldfinch.-Common Permanent Resident; abundant Transient Visitunt, March 10 to May 1; September 13 to October 10.

Purple Finch.-Common Winter Resident and abundant Transitent Visitant, March 10 to May 1; September 15 to November 1.

Rose-breasted Grosbeak.-Common Summer Resident, A pril 25 to October 10.

Towhee-Common Summer Resident; tolerably common

Winter Resident; Transien: Visitant, Murch 10 to April 15; September 25 to October 20.

Indigo Bunting.-Abundunt Summer Resident, April 25 to October 10.

Cardinal.-Cummon Permanent Resident.

Lark Finch.-Fairly common Sumuer Resident, Afril 13 to September 1.

Dickeissel._Abundant Summer Resident, April 15 to October 1.

Scarlet Tanager.-Common Summer Resident. April 20 to Septomber 24.

Barn Swallow,-Not common Summer Resident, April 10

to October 10.

Cliff Swallow.-Common Summer Resilent; abundant Transient Visitant, A pril 20 to September 24.

Bank Swallow.-Common Summer Resident; abundant Transient Visitant, A pril 20 to September 24.

Tree Swallow.-Common Transient Visitunt; rare Summer Resident, March 15 to April 20; September 1 to Octuber 20.

Purple Martin,-Common Summer Resident; abundant Transient Visitant. March 20 to September 24.

Cedar Waxwing. - Permauent Resident aud breeder. 
Northern Shrike.-Rare Winter Visitant, November 15 to March 1.

Red-eyed Vireo.-Common Summer Resident, April 17 to September 25.

Yellow-throated Vireo.-Common Summer Resident, April 13 to October 11.

White-eyed Vireo.-Common Summer Resident, April 15 to October 15.

Black and White Warbler.-Common Summer Resident, April 16 to September 29.

Yellow Warbler.--Summer Resident, April 20 to August 13.

Myrtle Warbler.-Abundant Transient Visitant; frequent Winter Resident, March 12 to May 12; September 17 to November 7 .

Black-throated Green Warbler.-Common Transient Visitant, April 26 to May 15; August 31 to October 8.

Redstart.-Common Summer Resident, April 16 to September 25.

Oven-bird.-Common Summer Resident, April 12 to October 2.

Maryland Yellowthroat.-Common Summer Resident, April 14 to October 2.

Chat--Common Summer Resident, April 19 to September 25 .

Catbird.-Common Summer Resident, April 16 to October 7.

Mockingbird.-Rather rare Summer Resident, and Permanent Resident, March or April to October.

Brown Thrasher.-Common Summer Resident, March 25 to October 20.

House Wren.-Common Summer Resident, April 9 to October 4.

Winter Wren-Rather rare Transient Visitant, March 25 to April 15 ; October 1 to 15.

Carolina Wren.-Common Permanent Resident; not so common as twenty years ago.

Long-billed Marsh Wren.-Fairly common Summer Resident, April 28 to October 28. 
Brown Cmepper.-Common Trunsient Visitant; mare Win. ter Visitant, March 10 to April 10 ; September 23 to November 4.

Chickadee.-Common Permanent Resident; Black-capperl Chickadee north of Missouri River; Curolina Chickadee south of it.

Tufted Titmouse.-Common Permanent Resident; less common than formerly.

White-breasted Nuthatch.-Common Permanent Resident.

Red-breasted Nuthatch.-Irregular Transient Visitant, A pril 25 to May 10 : September 4 to January 15.

Golden-crowned Kinglet.-Tolerably common Transient Visitant: rather rare Winter Resident; March 12 to A pril 10; September 29 to November 1.

Ruby-crowned Kinglet.-Abundant Transient Visitant; rare Winter Resident, April 1 to May 6 ; September $17^{\circ}:$ :Jetober 20.

Veery. - Tolerably common Transient Visitant, May 5 to 14 ; September 1 to 20.

Wood Thrush.-Common Summer Resident, April 15 to September 24.

Hermit Thrush. - Tolerably common Transient Visitant, April 1 to 27: October 1 to 25.

Robin.-Abundant Transient Visitant; common Summer Resident: tolerably common. Winter Resident, March 1 to November 10.

Bluebirl.-Tolerably common Summer Resident and frequent Winter Resident; migrates chiefly between Feb. ruary 25 and March 15; October 1 and November 10. 
NOTES FROM OBERLIN, O., ON BIRDS INCLUDED IN "BIRD-LIFE."

By Prof. Lynds Jones.

Pied-billed Grebe.-Uncommon Transient Visitant:

Lron.-Not, common Transient Visitant, late March to late October.

Herring Gull.-Common Transient Visitant on Lake Erie, March to May; September to Norember.

Common Tern.- Sometimes common Transient Visitant.

Wood Duck.-Uncommon Summer Resident.

Pintail.-Common Transient Visitant.

Mallard.-Now uncommon Transient Visitant.

Green-rwinged Teal.-Rare Transient Visitant.

Blue-winged T'eal._-Uncommon Transient Visitant.

Canada Goose.-Common Transient Visitant along the rivers.

Great Blue Heron.-Tolerably common Summer Resident, March 20 to September 15.

Little Green Heron.-Common Summer Resident, April 20 to November 13.

American Bittern.-Tolerably common Summer Resident, late March.

Sora. - Tolerably common Summer Resident.

American Coot.-Common Summer Resident along the rivers.

Woodcock,-Common Summer Resident, April to November.

Spotted Sandpiper.-Common Summer Resident, April 10 to September 15 .

Wilson's Snipe-Common Transient Visitant in spring, March 19 to April 28.

Semipalmated Sandpiper.-Uncommon Transient Visitant.

Killdeer.-Common Summer Resident, March 1 to Novem. ber 20 . 
Semipalmated Plover.-Uncommon Transient Visilant.

Bub-white. - Not common Permanent Resident.

Ruffed Grouse.- Rare Pernuneut Resident.

Mourniug Dove. - Abundant Sumuer Resident, late March to Novenber; rare in winter.

Turkey Vulture.-Tolerably common Summer Rosident, April 1 to September 15.

Red-shouldered Hawk. - Common Summer Resident, March to November; rave in winter.

Red-tailed Hawk. - Not common Summer Resident, February 1 to Decenber 15 ; rare in winter.

Marsh Hawk. - Unconımon Summer Resident.

Sparrow Hawk.-Common Summer Resident, April to October; rare in winter.

Sharp-shinned Hawk.-Rare Permanent Resident.

Cooper's Hawk.-Not common Sumner Resident ; rare in winter.

Bald Eagle.-Rare; common at Sandusky, and fairly common along the lake shore.

Osprey.-Rare : only seen along the lake shore.

Short-eared Owl.-Rare.

Long-eared Owl.-Tolerably common Permanent Resident.

Screech Owl.-Tolerably common Permanent Resident.

Barred Owl.-Uncommon Permanent Resident.

Yellow-billed Cuckoo.-Common Summer Resident, May 10 to September.

Black-billed Cuckoo. - Cormmon Summer Resident, May 5 to September 10.

Kingfisher.-Tolerably common Summer Resident, A pril to October; rare in winter.

Downy Woxlpecker. -Common Permanent Resident.

Hairy Wondpecker.-Common Permanent Resident.

Red-headed Woodpecker. - Abundant Summer Resident, A pril 15 to September 15 ; rare in winter.

Flicker. - Abundant Summer Resident, March to Novem. ber: rave in winter.

Nighthawk.-Very variable Summer Resident, May to September. 
Whip-poor-will. - Common Summer Resident, along streams only, May to September.

Chimney Swift.-Abundant Summer Resident, in towns; April 15 to October 10.

Ruby-throated Humningbird.-Not common Summer Resident, May 10 to September 10.

Kingbird.-Common Summer Resident, April 27 to August 10.

Crested Flycatcher.-Common Summer Resident, April 28 to October 1.

Phobe.-Common Summer Resident; late March to October.

Least Flycatcher.-Common Transient Visitant in spring, April 27 to May 22.

Wood Pewee.-Abundant Summer Resident, May 1 to September 12.

Prairie Horned Lark.-Common Permanent Resident. On December 18, 18:7, I found both alpestris and praticola in a flock of some one hundred aud twentyfive.

Crow.-Common Summer Resident; late February to November; rare in winter.

Blue Jay.-Common Permanent Resident.

Baltimore Oriole.-Common Summer Resident, April 25 to September 1.

Orchard Oriole.-Rare Summer Resident.

Red-winged Blackbird. - Common Summer Resident, March 10 to November.

Bronzed Grackle.-Abundant Summer Resident, March to November; rare in winter.

Bobolink.-Abundant Summer Resident, April 23 to September 15.

Meadowlark.-Abundant Summer Resident, March to November; rare in winter.

Cowbird.-Abundant Summer Resident, late March to October.

Song Sparrow.-Abundant Summer Resident, March to November ; rare in winter.

Swamp Sparrow.-Rare Summer Resident, late April. 
Field Sparmw.-Common Summer Resident, April I to October 20.

Vesper Sparrow, - Abundant Summer Resident, late March to early November.

Chipping Sparrow,-Common Summer Resident, early A pril to October.

White-throated Sparrow.-Common Transient Visitant, April 12 to May 12 ; October to November.

White-crowned Sparrow.-Common Transient Visitant. May 1 to 19 ; September 22 to October 10.

Fox Sparrow.-Tolerably common Transient Visitant. Murch 25 to A pril 20; October 20 to November 10.

Junco.-Common Transient Visitant, late March to May : October to December.

Tree Sparrow, -Common Winter Visitant, October 20 to April.

Redpoll.-Rare Winter Visitant.

Snowflake.-Rare Winter Visitant.

American Crossbill. - Very irregular Winter Visitant.

Pine Grosbeak. - Rare Winter Visitant.

Goldfinch.-Common Permanent Resident; abundant Summer Resident.

Purple Finch.-Tolerably common Winter Visitant, (c) tolver to May.

Rose-breasted Grosbeak.-Tolerably common Summer Resident. May to September.

Towhee.-Common Summer Resident, March 26 to October 20 .

Indigo Bunting.-Common Sunmer Resident, May to October.

Carlinal.-Tolerably common Permanent Resident ; mostly along rivers.

Dickcissel. - Variable Summer Resident, May to September.

Lark Finch.-Summer Resident, becoming common, A pril 28 to September 1.

Scarlet Tanager.-Common Summer Resident, May to September.

Barn Swallow.-Common Summer Resident, April 15 to September. 
Cliff Swallow.-Common Summer Resident, April 15 to August 15.

Bank Swallow-Common Summer Resident, April 20 to August 15.

Tree Swallow.-Rare Summer Resident, April 15 to August 15.

Purple Martin.-Common Summer Resident, April 1 to September 1.

Cedar Waxwing. - Variable Summer Resident. When it nests it remains the whole year.

Northern Shrike.-Not common Winter Visitant, November to March.

Red-eyed Vireo.-Common Summer Resident, late April to late September.

Warbling Vireo.-Common Summer Resident, late April to late September.

Yellow-throated Vireo.-Tolerably common Summer Resident, May 1 to September 10.

Black and White Warbler.-Common Transient Visitant, late April to May 15; September 10 to 20.

Yellow Warbler.-Common Summer Resident, April 20 to August 1.

Myrtle Warbler.-Common Transient Visitant, April 15 to May 15; September to November.

Black-throated Green Warbler.-Common Transient Visitant, April 25 to May 15; September 10 to 20.

Redstart.-Common Summer Resident, late April to October.

Oven-bird.-Common Summer Resident, late April to August.

Maryland Yellowthroat.-Common Summer Resident, late April to September.

Chat.-Not common Summer Resident, May to August 20.

Catbird.-Abundant Summer Resident, April 25 to October.

Brown Thrasher.-Common Summer Resident, April 15 to October.

House Wren.-Common Summer Resident, April 15 to October. 
Winter Wren.-Scarcely common Winter Visitant, No. vember to May 17.

Long-billed Marsh Wren. -Not common Summer Ronident. Brown Creeper. - Not common Trunsient Visitaut, late

March to Muy; October.

Chickadee,-Common Permanent Resident.

Tufted Titmouse. - Common Permanent Regident.

White-breasted Nuthatch. - Common Permanent Resident. Red-breasted Nuthatch.-Common Transient Visitant, April 1 to May 17; October.

Golden-crowned Kinglet. - Common Winter Visitant, Sep. tember 25 to April 25.

Ruby-crowned Kinglet.-Common Transient Visitant. A pril 1 to May 5: September 25 to October 20.

Veery.-Not common Transient Visitant and Summer Resident, May to September.

Wond Thrush.-Common Summer Resident, late A pril to September.

Hermit Thrush. - Not common Transient Visitant, April 15 to May 1: October.

Robin.-Abundant Summer Resident, February 15 tw Norember 25; a few usually winter.

Bluebird.-Common Summer Resident; early March to November.

NOTES FROM IN AND NEAR MILWAUKEE, WIS. ON THE BIRDS INCLUDED IN "BIRD-LIFE."

By H. Neunuma.

Pied-billed Grebe.-Tolerably common Summer Resident. A pril 10 to November 15.

Loon.-More or less common Summer Resident, April I to November 15 ; becoming scarcer.

Herring Gull, - Very abundant Winter Visitant, October 10 to May 5.

Wond Duck. - Very rare Summer Resident, March 20 to October 25. 
Pintail.-Summer Resident, March 18 to October 10. Mallard.-Summer Resident, March 17 to November 25, and later.

Green-winged Teal.-March 17 ; November 20.

Blue-winged Teal.-A pril 10 ; October 28.

Canada Goose.-March; September 20 to October 1; movements very irregular.

Great Blue Heron.-Common Summer Resident, April 1 to October 1.

Little Green Heron.-Summer Resident, May 1 to September 20 .

American Bittern.-Summer Resident, April 18 to September 25 .

Sora.-Common Summer Resident, April 26 to October 2.

American Coot.-Common Summer Resident, March 28 to September 20.

Woodcock. - Summer Resident, April 25 to October 5.

Wilson's Snipe.-Rare Summer Resident; common during migrations; April 15 to October 5.

Spotted Sandpiper.-Common Summer Resident, April 28 to September 25.

Semipalmated Sandpiper.-May 6.

Killdeer--Very common Summer Resident, March to October 10 ; nests in West Park.

Semipalmated Plover.-May 28.

Bob-white.-Extinct in Wisconsin.

Ruffed Grouse.-Permanent Resident, once common, now very rare.

Mourning Dove.-Summer Resident, April 30 to October 10.

Turkey Buzzard.-Very rare.

Red shouldered Hawk.-Summer Resident, March 20 to November 1 .

Red tailed Hawk.-Summer Resident, March 20 to November 5 .

Marsh Hawk. -Summer Resident, March 18 to October 15. Sparrow Hawk.-Rather common Summer Resident, March 18 to October 10.

Sharp-shinned Hawk. - Summer Resident, April 10 to October 1. 
Cooper's Hawk.-Summer Resident, April 20 to October 10 .

sprey.-Common Summer Resident, April 1 to Septem. ber 20.

Short-eared Owl.-Permanent Resident.

Long-eared Owl.-Permanent Resident.

Screech Owl.-Common Permanent Resident; nests in the eity.

Black-billed Cuckoo.-Summer Resident, May 8 to September 1.

Yellow-billed Cuckoo.-Rather abundant Summer Resident, May 9 to September 2 ; nests in orchards in the city.

Kingfisher.-Common Summer Resident, A pril 19 to September 18.

Downy Wooגpecker.-Permanent Resident.

Hairy Woodpecker. - Summer Resident, April 17 to October 1 ; probably winters.

Red-headed Woodpecker.-Very common Summer Resident, A pril 30 to September 20 ; nests in the city.

Flicker.-Summer Resident, April 13 to September 25: nests in the city.

Nighthawk.-Abundant Summer Resident, May 17 to August 25 ; uests on house-tops in the city.

Whip-poor-will.-Rather scarce Summer Resident, May 20 to August 31.

Chimney Swift.-Abundant Summer Resident, May 12 to September 10.

Ruby-throated Hummingbird.-Summer Resident, May 9 to October 6 .

Kingbird.-Common Summer Resident, May 9 to $\mathrm{Au}$ gust 15.

Crested Flycatcher, - Very rare Summer Resident, May 11 to Auguat 15.

Phobe.-Comuon Summer Resident, March 20 to September 30.

Wood Pewee-Common Summer Resident, May 20 to August 31 ; nents in the city.

Prairie Horned Lark.-Common Permanent Resident. 
Crow.-Permanent Resident.

Blue Jay.-Common Permanent Resident; nests in the city.

Baltimore Oriole.-Not numerous Summer Resident, May 9 to August 25.

Red-winged Blackbird. - Abundant Summer Resident, March 17 to November 1.

Bronzed Grackle.-Abundant Summer Resident, March 20 to October 26 ; nests in the city.

Bobolink.-Common Summer Resident, May 9 to September 1 ; not half so abundant as fifteen years ago.

Cowbird.-Very numerous Summer Resident, April 8 to September 15.

Meadowlark.-Common Summer Resident, March 17 to October 31.

Song Sparrow.-Common Summer Resident, March 17 to October 10; rare near the city.

Field Sparrow.-Rare Summer Resident, April 21 to September 20.

Chipping Sparrow.-Common Summer Resident, May 1 to September 10 ; nests in the city.

Vesper Sparrow.-Very common Summer Resident, April 10 to September 25.

White-throated Sparrow.-Very common Transient Visitant. April 28 to May 20; September 20 to October 22.

White-crowned Sparrow.-Abundant Transient Visitant, May 2 to 23: September 20 to October 4.

Fox Sparrow.--Irregular Transient Visitant, April 4 to April 18; October 25 to November 2.

Junco.-October 1 to April 10; breeds about 70 miles north of city.

Tree Sparrow.-November 1 to March 20; breeds farther north.

Redpoll.-Irregular Winter Visitant, occasionally abundant.

Snowflake.-Irregular Winter Visitant, sometimes abundant.

American Crossbill.-Irregular Winter Visitant, sometimes abundant. 
Pine Grosbeak.-Irregular Winter Visitant, sumetimes abuudant.

American Goldnnch.-Summer Resident, May 1 to Octo. ber; occasional is late as Decenber 25.

Purple Finch.-Summer Resident, April 12 to November 6 ; breods sparingly.

Rose-breasted Grosbeak. - Rather common Summer Resident, May 9 to September 15; nests in the city.

Towhee.-Common Summer Resident, April 20 w Septem, ber 15.

Indigo Bunting.-Rather common Summer Resident, May 9 to September 10.

Scarlet Tanager.-Summer Resident, May 9 to August 15: nests in the eity.

Barn Swallow.-Common Summer Resident, April 25 to August 25.

Cliff Swallow.-Summer Resident, April 30 to August 26. Bank Swallow.-April 30 to - ?

Tree Swallow.-Common Summer Resident, April 25 w August 25; nests in the eity.

Purple Martin.-Common Summer Resident, April 20 tus August 20.

Cedar Waxwing.-Permanent Resident of irregular move. ments; thousands winter; others migrate south ward, returning in May.

Northern Shrike.-Winter Resident, November 1 to March 5.

Red-eyed Vireo.-Summer Resident. May y to August 23.

Warbling Vireo.-Summer Resident. May 11 to August 25.

Yellow-throated Vireo. -Summer Resident, May 19 to August 20; nests in the city.

Black and White Warbler.-May 1 to August 27 ; breerl. farther north.

Yellow Warbler.-Common Summer Resident, May 9 to August 26; nests in the city.

Black-llımated Green Warbler.-Common Transient Visitant. May 9 to May 15; August 15 to September 1.

Myrtle Warbler.-Transient Visitant, April 17 to May 1;

October 1 to October 10. 
Redstart.-Common Summer Resident, May 9 to August 26.

Oren-bird.-Abundant Summer Resident, May 6 to September 5.

Yellow-breasted Chat.-Rare.

Maryland Yellowthroat.-Common Summer Resident, May 5 to August 20.

Catbird.-Common Summer Resident, May 5 to August 25. Brown Thrasher.-Summer Resident, April 25 to September 1.

House Wren.-Common Summer Resident, May 1 to August 25.

Long-billed Marsh Wren.-Common Summer Resident, May 15 to September 6.

Brown Creeper.-April 4 to October 28 ; appears to breed near here.

Chickadee.-Permanent Resident.

White-breasted Nuthatch.-Permanent Resident.

Red-breasted Nuthatch.-April 22, and again November 1 ; movements irregular; breeds farther north.

Golden-crowned Kinglet.-April 4, and again October 1 to October 10.

Ruby-crowned Kinglet.-April 10, and again September 3 to October 2.

Veery.-Summer Resident, breeding sparingly, May 9 to August 31.

Wood Thrush.-Summer Resident, April 31 to September 2.

Hermit Thrush.-April 10; October 1; breeds farther north.

Robin.-Common Summer Resident, March 17 to October 1.

Bluebird. - Summer Resident, March 17 to October 15. 


\section{SUBJECTIVE LESSONS.}

Factors of Evolution (Chapter II, pages 14-16).-Give examples illustratitig the diversity shown in the structure and habits of birds. What theory has been advanced to account for the wide variation in structure shown by birds ? What is meant by Natural Selection? Ilow does the theory of Lamarck differ from that of Darwin? How may the tail-feathers of the Woodpecker have acquired their present poisted shape? Is it probable that the Wrod. pecker's barbed tongue has been acquired in the same manner ?

\section{FORM AND HABTT.}

The Wing (Chapter II, pages 17-24).-Name the functions of the wing. What is doubtless its most primitire use as an organ of locomotion ? How is it used by young Gallinules? By the young Hoatzin? How is it used by Grebes and Penguins? By the Ostrich? What variatiun in expanse of wings is presented by birls? What rela. tion exists between shape of wing and style of flight? Give illustrations. Mention sonve flightless birls. Why is flight necessary to the Razor-billed Auk? Under what conditions might it exist without the power of flight? What group of fliglitless birds is found in the Antarctic region? Where do they nest? Why? What birls become temporarily flightless? In what unanner? What lake is inluabited by a flightless Grebe ? Where are flightless Gallinules found? How did they probably mach the islands they now inhabit? Mention other fightless birls.

- The value of these lessons will be greaily enhaneerl if the tencher will constanily have the pupil name alslifional sjecies in illustration of the lncts and theories hero mentioued. 
In what manner is the wing sexually adorned? How is it used as a musical instrument? How may it express emotion ?

The Tail (Cliapter II, pages 25-27).-Mention some birds in which the tail is sexually dereloped. What is the tail's main office? Gire illustrations of its relation to the character of flight. What birds use the tail as a prop? Describe the tail of the Motmot. How may the tail express emotion? Give illustrations.

The Feet (Chapter II, pages 27-30).-What relation exists between the feet and wings? Give illustrations of the relation between the structure of the feet and the manner in which they are used. On what is length of foot sometimes dependent? Describe the Jacana's toes? Of what assistance are they to the bird? What birds use the feet in scratching for food? What birds use the foot as a hand? Of what special use is it to the Birds of Prey? Mention sereral species which use the foot as a weapon. Describe the seasonal modification in the feet of Grouse.

The Bill (Chapter II, pages 30-34).-To what human organ does the bill correspond in use? Mention some of the functions of the bill. What is its most important office? What does the bill in effect become? To what is its shape in Hummingbirds related? Give illustrations.

- What is a marked character of the bill of some fish-eating birds? How is the bill used by some shore birds? Give illustrations. Describe the shape and uses of the Huiabird's bill.

\section{Colors OF BIRDs.}

Color and Age (Chapter III, page 36).-What is the character of the nest plumage of birds that run or swim at birth? Of birds that are reared in a nest? Give illustrations. What plumage follows the nest plumage? Does it resemble that of the parent? How long is it worn? Does the immature plumage sometimes differ from that of the adult ? Give illustrations. When does the Bobolink acquire his full plumage? When, the Orchard Oriole?

Color and Season (Chapter III, page 37).-When the 
male differs from the female, what seasonal change in color may occur ? If the sexes ure alike, is there much variution in color ?

The Molt (Chapter III, pages 37, 38). - How are changea in a bird's plunage cliefly accomplished? Is the process of molting subject to much rariation? What are these variations apparently dependent on? At what time of the year do all birds molt? What usually oceurs the following spring ? Do any birds have a complete spring molt ? Are special plumes ever acquired at this senson? Describe the manner in which the Snowflake gains its brceding dress.

Color and Food (Chapter III, page 39).-How is the color of Canaries sometimes altered? What is the effect of red pepper on fowls? What is sometimes fed to Parrots to change their color? How do Flaningoes and Scarlet Ibises illustrate the relation between color and food? What color does the Purple Finch become in captivity ?

Color and Climate (Chapter III, pages 39-11).-IIow does climate affect the colors of birls? What does this demonstrate? How many races of Song Spurrows are known ? What relation exists between their colors and the climate of the regiuns in which they live? Where are the extrenes in color found? Are these extremes connected? What is the prevailing character of the colors of Arizona birds? Of nor:hwest corast birds ? What are these races of birds? Under what conditions might they become species ?

Color and Haunt and Habit (Chapter III. pages 41-44).What is necessary to an understanding of the value of the colors of birds? What is the offlce of protective coloring? What of deceptire coloring? What are the prevail. ing colors of ground-inhabiting birls? Give examples Are tree-inhabiting bircls brighter than those that live on the ground? What explanation is advanced to acount for this? How do we receive an erroneous iden of the cul. ors of tropical birds? What has Mfr. Thager proved? What fact does he call attention to ? How does this tenil to conceal the animal How does Mr. Thayer deunon. 
strate his theory? Mention one of the best arguments for the value of protective coloration. Give illustrations. What birds illustrate the value of deceptise coloring? What are recognition or signalling colors? Give illustrations.

Color and Sex (Chapter III, pages 45-47).-The pupil should learn the Synopsis of Secondary Sexual Characters, and give one or more illustrations of each kind of sexual-difference mentioned. Explain and illustrate Darwin's theory of sexual selection. How does the theory of Wallace differ from that of Darwin?

\section{The Migration of Birds.}

Extent of Migration (Chapter IV, page 49).-Upon what is the extent of migration often dependent? Explain this. Where do most migratory western species winter? Where do our eastern migratory Sparrows and berry eaters winter? Where do the majority of our eastern insectivorous species winter? What route do they follow? How far south do some Plover and Snipe winter?

Times of Migration (Chapter IV, pages 49-53).-This branch of the study of bird migration is covered much more fully under the section devoted to seasonal lessons, where the method of treatment is suggested. The matter here given should be used in connection with the added material in the section named.

Manner of Migration (Chapter IV, pages 54-57). - What is the first step in the fall migration? Do old or young birds lead the way? What birds fly by night? Why? Give examples. What birds migrate chiefly by day? Why? Give examples. What birds migrate exclusively by day? Why? Give examples. What constitute highways of migration? At what height may migrating birds travel? Of what advantage is this height to them? When are birds attracted to lighthouses? How may one observe the night migration of birds ? How many birds were thus observed at Tenafly. N. J.? Describe the observations made from the Bartholdi Statue. 
Origive of Migmation (Chapter IV, pages 88-61). - Wiunt theory is here alvanced to account fur the origin of hind migration 1 What other asiumals migrate? What do most animuls seek during the period of repmaluction ? Give illustrations. Describe the migrations of certain ma birds. What lass been the prubable influence of the giacial perion on bird migration? Describe the mute followed by Bobulinks when migrating. What does this illustrate? In what manner does the migration of birds resemble the flight of the Carrier Pigeon ?

\section{THe Volce or Brmps.}

Song (Chapter V. page 62).-What is song ? What is its chief function? Mention several types of bim music. To what does the song season correspond? When and by what species is it inaugurated? When is it practically concluded? Is there a second song period? What birms first cease singing? What birls are unidsummor singers?

Call-notes (Chapter $\mathrm{V}$. page 65). - What is the relation of call-notes to song? What do the calls of the Robin express? Do birds inherit the calls and songs ? Do they ever acquire the notes of other species?

\section{The Nestina Season.}

Time of Nesting (Chapter VI. pnge 61). - At what seasun do migratory birds nest ? When do tropical birls nest? Why are bimls obliged to uest at a certain season ? Give some examples illustratiug the relation between nesting time and food.

Mating (Chapter VI, page 65).-(See page 45, Synopmis of the Secoudary Sexual Chameters of Bimls.)

The Nest (Chapter VI, pages 65-68). - What is the firut step in nest-building? Mention several sites in which biruls may nest. What is the chief desideratum? Why can sea birls often lay their eggs in exprosed places? How is tum. perament shown in nesting? Mention several kinds of material used by birds in nest-buildiug. How hove bink 
as nest-builders been classified? Do both sexes assist in nest-building? How much time may be cousumed in the construction of a nest? Meution the eight factors governing tine character of birds' nests and give examples illustrating each.

The Eggs (Chapter VI, pages 68-70).-How many eggs may compose a full set? If the nest is robbed, will the eggs be replaced? Give illustrations. Of what is the eggshell composed? To what is the color of eggs due? How may variations in color be effected? Is there much variation in the color of the eggs of the same species? Why are the eggs of præcocial birds larger than those of altricial birds? Give examples. What are the extremes in the period of incubation? Do both sexes incubate?

The Young (Chapter VI, page 70).-The mental and physical growth of the Chicken form an excellent and practical lesson in the development of a young bird. A newly hatched chick may be procured and placed in a suitable cage in the class-room, where its actions and plumage may be closely studied. Experiments may be made, showing how little inherited knowledge the chick possesses, by giving it bits of worsted, etc., to eat, and observing how it learns what is and what is not edible, how it does not instinctively recognize water, etc., and at the same time notes should be kept of its changes in plumage. 


\section{CLASSIFICATION OF THE BIRDS OF NORTH AMERICA."}

\section{ORDER I.-PYGOPODES (DIVING BIRDS).}

Ducklike birds, with generally sharply pointed bills; feet webbed, placed far back near the tail; tarsus much flattened; hind toe, when present, with a lobe or flap: bill without toothlike projections; tail very short. and sometimes apparently wanting.

Family 1.-Podicipidae. Grebes; 6 species.

Fayily 2.-Urinatorida. Loons; 5 species.

Faxuly 3.-Alcida. Auks, Murres, and Puffins; 22 species.

\section{ORDER II. - LONGIPENNES (LONGWINGED SWIMMERS).}

Binds with sharply pointed and frequently hooked or hawklike bills; toes four (except in the genus Risscs), the front ones webbed: wings long and pointed.

FastuY 4.-Stercorariide. Skuas and Jaegers; 4 species.

Famix 5.-Laridoe. Gulls and Terns; 43 species.

FAmul 6. -Rynchopida. Skimmers; 1 species.

\section{ORDER II.-TUBINARFS (TUBE-NOSED SWIMMEIR).}

Bill hawklike, the tip of the upper mandible generally much enlarged; nostrils opening through tubes; hind toe

- The armangement and nomenclature here given is lused on the Amorican Ornithologist Union's Check-List, 2d edition, I805. 
reduced to a mere nail, and sometimes entirely wanting ; frout toes webled.

Family 7.-Diomediidae. Albatrosses; 4 species.

Family 8.-Procellariidoe. Fulmars, Petrels, and Shearwaters; 28 species.

\section{ORDER IV.-STEGANOPODES (TOTIPALMATE SWIMMFRS).}

Toes four; all connected by webs.

Famly 9.-Phaëthontidoe. Tropic Birds ; 2 species.

Family 10.-Sulidoe. Gannets; 6 species.

FaMiLY 11.-Anhingidoe. Darters; 1 species.

FaMily 12.-Phalacrocoracidoe. Cormorants; 6 species.

Family 13.-Pelecanidoe. Pelicans; 3 species.

Family 14.-Fregatidoe. Man-o'-War Birds; 1 species.

\section{ORDER V.-ANSERES (LAMELLIROSTRAL SWIMMERS)。}

Toes four, the front ones fully webbed ; tarsus not flattened as in the Grebes; bill with toothlike projections, fluted ridges, or gutters on its sides.

Family 15.-Anatidoe. Ducks, Geese, andi Swans; 54 species.

\section{ORDER VI.-ODONTOGLOSSE (LAMELLIROSTRAL} GRALLATORES).

Toes four, the front three webbed; bill with toothlike ridges as in some Ducks, the end half bent downward; legs long; tarsus 12.00 inches or more in length.

Famux 16.-Phonicopteridoe. Flamingoes; 1 species.

\section{ORDER VII-HERODIONES (HERONS, STORKS, IBISES, ETC.)。}

Toes four, all on the same level, slightly or not at all webbed; lores bare; legs and neck generally much lengthened. 
Famir 17.-Plataleido. Spoonbills ; 1 species.

Fasutry 18. - Jbididas. Ibisess ; I speries.

Famity 19.-Ciconiidar. Storks und Wood Ibises; 2 species.

Fasur. 20. - Ardeidae. Herons, Bitterns, etc.: 15 specie:

\section{ORDER VIII. PALCDICOLA (CRANES, RAILS, FTC.).}

Toes four: midclle toe without a comb, generally not webbed: hind toe generully small, higher than front ones, or when on the same level (Gallinules and Conts on(5), the bill is comparatively short and stout, and the formeneal has a bare shield ; lores feathered, or with hairlike bristles (Cranes).

Famil 21. - Gruidoe. Cranes; 3 species.

FamLy 22.-Aramidae. Courlaus; 1 species.

Fasur. 23. - Rallidae. Rails, Gallinules, and Coots; 17 species.

\section{ORIVIR IX.LIMICORAE (BHORE BIRDS).}

Toes four or three; the hind toe, when present, less than half the length of the inner one, and always elevated above the others; leas generally long and slender, the lower half of the tibias bare : bill, in the true Snipe, generally long. slender. und soft. the nostrils opening through slits or gmores ; wings long and pointed, the first primary generally the largeat.

Famur 24.-Phalaropodidae. Phalampes: 3 species.

Faxu.y 25.-Kecurvirostridae. Arocets and Sitilts; 2 apecies.

Famr.y 26. - Scolopacida. Snipes and Sandpipers; 43 species.

Faxul 27.-Charadride. Plovers; 13 species.

FayuY 28. - Aphrizidae. Surf Birls and Turnstones: 8 species.

Fasuy 29. - Hamatopodidae. Oyster-catchers; 4 species.

Fıацу 30.-Jacanida. Jacanas; 1 species. 


\section{ORDER X.-GALLINA (GALLINACEOUS BIRDS)。}

Toes four, the hind one small and elevated abore the front ones; bill generally short, stout, hard, and horny; wings short, the outer primaries curved and much stiffened.

F AMrly 31.-Tetraonidoe. Grouse, Partridges, etc.; 20 species.

Family 32.-Phasianidoe. Pheasants, Turkeys, etc.; 1 species.

Family 33.-Cracidae. Curassows, Guans, etc.; 1 species.

\section{ORDER XI.-COLUMBA (PIGEONS).}

All four toes on the same level; the hind toe about as ling as the shortest front one; bill rather slender, deeply grooved; the nostrils opening in a soft fleshy membrane or skin.

Family 34.-Columbidoe. Pigeons; 13 species.

\section{ORDER XII_RAPTORES (VULTURES, HAWKS, AND OWLS).}

All four toes armed with strong, sharp, curved nails or talons; the hind toe, except in the Vultures, as long as or longer than the shortest front one; bill with a cere, or covering of skin, at its base, through which the nostrils open, very strong and stout, the tip of the upper mandible with a sharply pointed hook.

FAMILY 35.-Cathartidoe. American Vultures; 3 species.

Famru 36.-Falconidoe. Vultures, Falcons, Hawks, Eagles, etc.; 39 species.

Family 37.-Strigidoe. Barn Owls; 1 species.

FaMiLY 38.-Bubonidae. Horned Owls, Hoot Owls, etc.; 17 species. 
ORDER XIII,-PGITTACI (PARROTS, PAROQUETS, ETC.).

Toes four, two in front and two behind; bill with a cere, or covering of skin, at its base.

FAstu.y 39. - Psittacidoe. Parrots and Paroquets; 1 species.

\section{ORDER XIV.-COCCYGES (CUCKOOS AND KING.}

\section{F1SHERS).}

Toes four, two in front and two behind (Cuckoos), or three in front. the middle and outer ones joined for half their length; bill without a cere.

Fasmly 40.-Cuculida. Cuckoos, Anis, etc. ; 7 species.

FAmLY 41.-Trogonida. Trngons ; 1 species.

Family 42.-Alcedinido. King fishers ; 3 species.

\section{ORDER XV.-PICI (WOODPECKERS).}

Thes four, or, rarely, three; two in front; bill strong: tail-feathers usually pointed and stiffened.

FAsuly 43.-Picidar. Woodpeckers ; 24 species.

\section{ORDER XVI.-MACROCHIRES (GOATSUCKERS, 8WIFTS, AND HUMMINGBIRDS)。}

Feot very small and weak; bill short, and mouth large (Goatsuckers and Swifts), or bill long and exceedingly slender (Hummingbirds); wings generally long and pointed.

FaMily 44.-Caprimulgidar. Goatsuckers, 6 species.

FasILy 45. - Mieropodidae. Swifts ; 4 species.

FaMLy 46.-Trochilida. Hummingbirds; 18 species.

\section{ORDER XVII.-PASSERES (PERCHING BIRDS).}

Toes four, without webs, all on the same level: hind toe as long as the middle one; its nail generally longer 
than that of the middle one; foot, therefore, fitted for perching.

Family 47.-Cotingidoe. Cotingas; 1 species.

Family 48. - Tyrannidoe. Flycatchers ; 33 species.

FAMILY 49.-Alaudidoe. Larks; 2 species.

Family 50.-Corvida. Crows, Jays, Magpies, etc.; 20 species.

Family 51.-Sturnidae. Starlings; 1 species.

Family 52.-Icteridae. Blackbirds, Orioles, etc.; 20 species.

Family 53.-Fringillidoe. Finches, Sparrows, etc.; 94 species.

Family 54.-Tanagridoe. Tanagers; 6 species.

Family 55.-Hirundinidoe. Swallows; 10 species.

FAmily 56.-Ampelidoe. Waxwings, etc.; 3 species.

FaMILY 57.-Laniidoe. Shrikes; 2 species.

FAMILY 58.-Vireonidoe. Vireos; 12 species.

Family 59.-Carebidoe. Honey Creepers; 1 species.

FAMILY 60.-Mniotiltidae. Wood Warblers; 59 species.

Family 61.-Motacillida. Wagtails ; 7 species.

Family 62.-Cinclidar. Dippers; 1 species.

FAMILY 63.-Troglodytidce. Wrens, Thrashers, etc.; 25 species.

Family 64.-Certhiidoe. Creepers; 1 species.

Family 65. - Paridoe. Nuthatches and Tits; 21 species.

FAMILY 66. Sylviidoe. Kinglets and Gnatcatchers; 7 species.

FAmily 67.-Turdidoe. Thrushes, Bluebirds, etc. ; 15 species. 




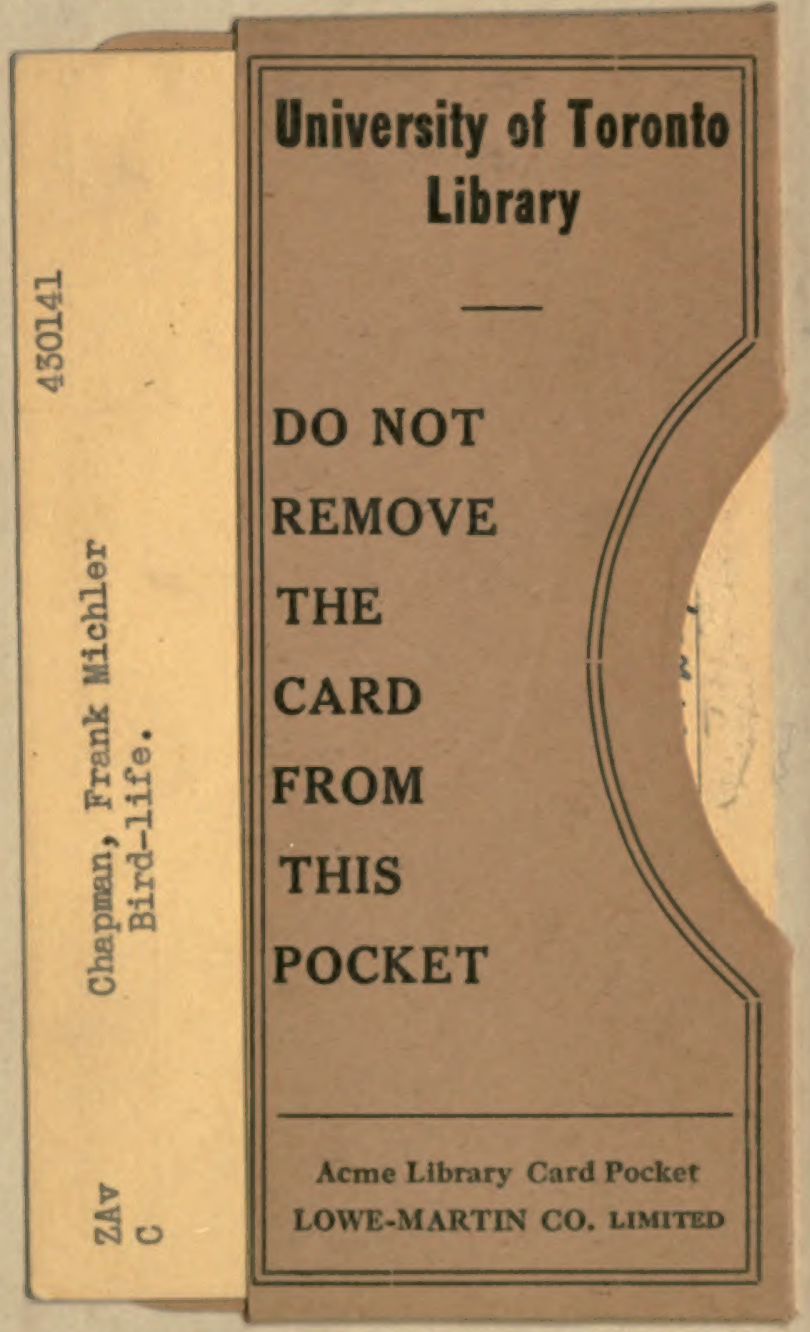


